Universidad Nacional de La Plata

Facultad de Humanidades y Ciencias de la Educación

Secretaría de Posgrado

Doctorado en Letras

Tesis doctoral

\title{
El ensayo como escenario de autofiguración en la obra de Cyril Connolly
}

Doctorando: Prof. Eugenio Conchez Silva

Director: Dr. José Amícola

Codirector: Dr. Miguel Ángel Montezanti 
Introducción

1. Cyril Connolly, hombre de letras $\quad$............................ 12

1.1. Hombre de letras: problemática y amplitud del concepto ................ 12

1.2. Orígenes y antecedentes. Una tradición europea $\quad \ldots \ldots \ldots \ldots \ldots \ldots \ldots \ldots \ldots$

1.3. El hombre de letras en la tradición inglesa ........................... 19

1.4. Cyril Connolly y los últimos hombres de letras ...................... 30

2. Cyril Connolly, ensayista $\quad$.................................. 42

2.1. Orígenes del ensayo: una tradición europea $\quad \ldots \ldots \ldots \ldots \ldots \ldots \ldots \ldots . \ldots 42$

2.2. Las problemáticas del ensayo como género proteico $\quad \ldots \ldots \ldots \ldots \ldots \ldots \ldots .51$

2.3. Particularidad de los ensayos de Cyril Connolly $\quad$................... 57

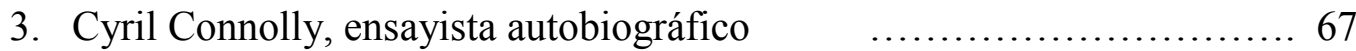

3.1. En torno a la autofiguración $\quad$................................... 67

3.2. Ensayo y autofiguración: problemáticas y modos $\quad$................... 70

3.3. Procesos de autofiguración en la obra de Cyril Connolly $\quad$............ 75

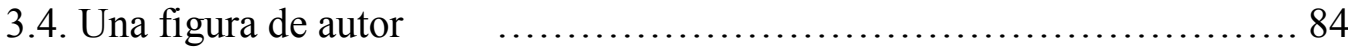

4. Los libros mayores: Enemigos de la promesa y La tumba inquieta _....95

4.1. Enemigos de la promesa, $1938 \quad$............................... 95

4.2. La tumba inquieta, $1945 \quad$.................................. 125

5. Fundamentos autobiográficos de la crítica literaria $\quad \ldots \ldots \ldots \ldots \ldots \ldots . \ldots 140$

5.1. El papel del crítico en la formación del valor literario $\ldots \ldots \ldots \ldots \ldots \ldots . . \ldots 140$

5.2. Cyril Connolly, lecturas de un hombre cultivado $\quad$............... 149



5.4. Cyril Connolly, personaje y fundamento $\quad$....................... 161

Conclusiones 


\section{Introducción}

Desde que en 1571 Montaigne dio el nombre de "ensayos" a sus meditaciones y composiciones dispersas sobre temas variados, el género quedó caracterizado por la nota personal, por la sombra del autor mezclándose con su tema. La tradición inglesa del ensayo ha sido heterogénea y sólida; iniciada por Francis Bacon, pasando por John Dryden, Joseph Addison, Samuel Johnson, William Hazlitt, Oscar Wilde, entre otros, tiene en Cyril Connolly (1903-1974) un digno exponente.

Como en muchos de los autores mencionados, el ensayo de tema literario y la crítica de literatura cobran capital importancia en la producción de Cyril Connolly. Ensayo, autobiografía, cartas, diario personal, editoriales, artículos, miscelánea, conforman un corpus donde la misma variedad confluye en la creación de un personaje polifacético; desde la dirección de la revista Horizon, el articulismo en importantes diarios y la publicación de sus libros ensayísticos, intenta mantener un ideal de compromiso estético y literario en un mundo convulsionado por las luchas políticas, aplicando nociones de gusto y estilo que tendrán influencia en la conformación de un canon literario del movimiento moderno europeo.

Dado el cariz subjetivo de estos escritos, se impone develar y reconstruir a partir de ellos la figura del crítico y hombre de letras, cuyo estilo y cualificación nos proponen. El ensayo, con su forma libre y poco restrictiva, se presenta como un género apto para el despliegue de la escritura a múltiples niveles. Mediante esta operación, se dan relaciones diversas en la imbricación que mantienen los distintos discursos en el interior del género.

Así, el objeto de estudio de la presente tesis será la obra ensayística de Cyril Connolly, tomando en cada capítulo los ensayos más pertinentes para el desarrollo de mis postulados. La publicación, iniciado el siglo XXI, de sus Selected Works (2003), con la consiguiente traducción al castellano (Obra selecta, 2005), denotan, tal vez, una nueva valoración de su obra, y de su forma de entender y practicar la literatura. A través de la autofiguración Connolly delinea un tipo particular de personaje, de ensayista y crítico literario, cuya configuración a través de sus textos ensayísticos creo importante estudiar. Las relaciones entre autofiguración y ensayo, dado que en muchos de ellos Connolly ejerce la crítica literaria, nos conducen al análisis de los fundamentos de este tipo de crítica, donde lo personal es un elemento visible y hasta productivo; y más allá, a preguntarnos por las relaciones que mantiene el discurso crítico en literatura con la instancia subjetiva. 
La necesidad de poner su obra y figura en un contexto presta capital importancia a la problematización de sus relaciones con la tradición del género y a la configuración de su posicionamiento dentro del campo literario. Hombre de letras y ensayista, Connolly es un autor excéntrico pero que ocupa un lugar reconocible en su tradición; el estudio comparativo con antepasados y contemporáneos pondrá de relieve continuidades, rupturas y particularidades.

Por su parte, la obra y figura de Cyril Connolly han sido objeto de interés constante; velado personaje de novelas, sujeto de dos biografías, memorias, nombre asiduo en los epistolarios y diarios de sus contemporáneos, su figura extravagante y controvertida ha suscitado multiplicidad de comentarios. Enemigos de la promesa (1938) y La tumba inquieta (1945) son ya clásicos del ensayo en lengua inglesa; en el año 2003, como ya dije, se publicó una edición en dos tomos de sus Selected Works; una edición castellana, Obra selecta, fue publicada dos años más tarde (recupera traducciones de libros ya editados en España por la editorial Versal, frutos de un interés por Connolly durante los 90, y agrega nuevas traducciones) y en 2009 fue lanzada en formato de bolsillo.

Sin embargo, este interés no ha redundado en estudios críticos de extensión. La aventura de su fracaso, de brillante promesa a escritor de la no-escritura; sus matrimonios, gustos, viajes y ocios; su relevancia en el mundo literario inglés y su escritura dispersa e inclasificable, que muchas veces tiene al autor por personaje, tal vez hayan incidido en que su vida sea el interés principal de la mayoría de los escritos, centrados así en memorias, semblanzas y biografías. Luego, encontramos un grupo de textos consistente en artículos y reseñas de sus obras que, con más o menos profundidad, esclarecen algunos puntos y dejan planteadas algunas líneas de investigación.

Existen dos extensos estudios sobre la revista Horizon y el desempeño de Cyril Connolly como editor: Friends of Promise. Cyril Connolly and the World of Horizon (1989) del biógrafo y profesor norteamericano Michael Shelden y Wartime Text and Context: Cyril Connolly's Horizon (2007), tesis doctoral de Dennis Joseph Boykin, de la Universidad de Sydney. La tesis de Boykin se dirige a demostrar que "contrary to the commonly held view, Horizon consistently offered space for political debate, innovative criticism, and war-relevant content" (Boykin: Abstract, sin número de página). En el capítulo primero, dedicado enteramente a la labor de Connolly como editor, Boykin 
analiza sus 'Comments' en la revista para demostrar que existe un cambio entre los primeros, que ponen énfasis en el esteticismo, y los que vienen luego, que, si bien mantienen esa postura, muestran un compromiso mayor con la realidad de la guerra. Nos parece relevante rescatar dos citas que aciertan sobre la forma de trabajo de Connolly: "The recollections of the magazine offered by his colleagues and contemporaries are all characterised by descriptions of Horizon as a product of Connolly's unique personality, masterful literary ability and idiosincratic editing style"; "He imbued all of his writing with autobiography, and was generous in sharing his thoughts, feelings, hopes and fears, as his editorial contributions amply demonstrate" (Boykin 25). Se insiste en la decisión de Connolly con respecto al principal propósito de la revista: "the good writing”, todos los demás quedaban supeditados a éste.

El libro de Michael Shelden, minucioso y bien documentado, se propone contar la historia de la revista Horizon (1939-1949) y de los personajes y el mundo que la conformaron, haciéndolo "in a way which blends literary history with criticism and biography” (Shelden 10). Sin embargo, la vía crítica, en cuanto crítica textual, está ausente. Se mencionan los libros que Connolly escribe en este período, pero siempre en relación con las circunstancias biográficas que revelan y la repercusión o no que tuvieron; como bien lo señala en su tesis Boykin "Shelden's own study is extensive in its way [el rol de Connolly como editor], but is predominantly biographical." (Boykin 25). Si bien hay enunciados que toman la dirección de mis hipótesis, se trata siempre de afirmaciones que no tienen un desarrollo argumental posterior; a modo de ejemplo:

This shrewd analysis of modern writers and modern literary life revealed a first rate critical intelligence, and readers were intrigued by the book's unconventional mixture of criticism, autobiography and candid literary shoptalk. When Horizon was launched a year later, its success confirmed that the author of Enemies of Promise was among his generation's most talented men of letters. (Shelden 3)

Realiza Shelden una positiva valoración de Connolly como ensayista dotado, de prosa cuidadosamente trabajada, capaz de diseccionar un objeto en sus partes más importantes para luego dejarnos su opinión en un par de frases memorables (2). En cuanto al género de estos escritos, no hace una clara distinción: diario, ensayo, autobiografía, crítica se mencionan siempre sin establecer la relación, funcional o no, que mantienen en los textos (es el caso de la mayoría de los críticos que se ocupan de la obra). Cita a un anónimo crítico del Times Literary Suplement, que en una reseña de 1954 observa: "It may well be that Mr Connolly's ultimate achievement will be fragmentary, informal and 
occasional -using those terms as descriptive and not pejorative." (10) La advertencia de la condición fragmentaria de estos escritos es juzgada como un acierto.

El mismo año de su aparición, Hilton Kramer hace una extensa y elogiosa reseña para The New Criterion del libro de Shelden, comenta: "is the kind of literary history, replete with vivid biographical portraits and shrewd critical judgements" (Kramer). Si bien juzga que es el mejor acercamiento a la obra de Connolly que ha leído, le reprocha a Shelden ser un admirador obnubilado: si los aciertos están debidamente valorados, nada se dice del resto (que, por lo demás, son juicios morales del propio Kramer). Sólo dedica un párrafo a la crítica de los libros de Connolly: Enemigos de la promesa y La tumba inquieta le parecen piezas de época; sus colecciones de ensayos, si bien todos contienen cosas buenas, ninguno puede ser descripto como gran crítica, opina. Concluye: "He [Connolly] was a remarkable man, despite his flaws and his failures, and Horizon was his most remarkable accomplishment" (Kramer), y felicita a Shelden por haber escrito un libro que le haga justicia.

Estos estudios merecen un interés lateral en este trabajo; ni la revista Horizon ni la labor de Connolly como editor son objetos de estudio. Los autores coinciden en el carácter heterogéneo de los escritos de Connolly -que nunca saben cómo clasificar- y los ven siempre relacionados con la crítica y la autobiografía. La mención, por supuesto, me parece pertinente, pero no se establecen relaciones significativas entre los dos términos; así como tampoco cuáles son los juicios críticos y los procesos de autofiguración que migran a través de textos disímiles. Coincido en que hay una postura que se podría llamar esteticista en la defensa de la buena escritura por sobre todo otro criterio, sin embargo, falta aclarar lo que Connolly considera como tal para establecer cuáles son su posición y sus parámetros críticos.

"The Cost of Myth: Cyril Connolly and Romanticism" es un trabajo monográfico de Jean-Christophe Murat en el que se da cuenta de la relación ambivalente de Connolly con el romanticismo; para esto se analizan las valoraciones y menciones que sobre el movimiento, los autores y la actitud romántica hace Connolly al escribir su autobiografía de formación (III cap. de Enemigos de la promesa) y su posición ante la guerra en La tumba inquieta (con ecos de fin de mundo, lo que justifica la comparación con La decadencia de Occidente, de Spengler). Coincido en que existe una relación emocional y literaria que liga a Connolly con el romanticismo, y será tenida en cuenta siempre que eche luz sobre algún aspecto de su obra. Señala Murat la insistencia de 
críticos y biógrafos en establecer una relación indisoluble entre la vida y la obra de este hombre de letras, y juzga que esto "tends to suggest the amateurishness of his output as a critic and essayist, in a way which, by contrast, sacralizes the professionalism of his contemporaries F. R. and Q. D. Leavis, fulltime, widely respected academics" (Murat 104). Uno de los objetivos de este trabajo es problematizar esa relación vida-obra, teniendo siempre en cuenta que se establece dentro del mismo texto y, por tanto, no se trata de una situación especular sino de un trabajo literario, de estrategias de autofiguración del propio Connolly. No juzgo acertada la división entre profesional y amateur basándose en el criterio diferencial de la aparición o no de la figura del autor en su texto, pero sí un punto problemático que abre caminos de investigación. Sobre los métodos críticos, se refiere a su utilización de las nociones de mandarin y vernacular para analizar las tendencias de la época como "unquestionable enlightening and thought provoking” (110-111). No resulta iluminador en cuanto a la situación genérica de los dos libros más importantes de Connolly; de Enemigos de la promesa dice que es un texto híbrido, y luego describe sus tres apartados (109); y La tumba sin sosiego, excepto su epílogo, que se lee como un ensayo académico, el texto está compuesto por párrafos desarticulados y sin relación aparente (111). En ninguno de los dos casos se menciona un eje o intención probable que dé unidad a estos libros. Más allá de coincidir en la existencia de algún tipo de hibridez, existe una unidad de conjunto en estos libros de Connolly, donde las distintas partes se afectan resignificándose.

Lo que para Murat puede considerarse un punto de vista que va en demérito de la obra de Connolly, es para William Boyd uno de sus aciertos principales:

Yet the more one reads and the more one learns about him perhaps the fairest conclusion to arrive at is that Cyril Connolly's greatest memorial -his particular masterpiece- is precisely that conjunction of life and work. (Boyd)

Podemos ver que, si bien la valoración es la contraria, el error es el mismo. Pasa Boyd, gran admirador de Connolly, a afirmar que, si bien todo lo que escribió tiene estilo e inteligencia, apasionada erudición, ningún libro o colección de sus escritos puede considerarse inequívocamente excelente; sin embargo, la suma de sus partes le parecen algo formidable; lo que lo estimula de ellos es la pasión y el entusiasmo que contagian. La honestidad de Connolly, sobre todo en la confesión de sus fallas, le parece a Boyd que hace de su obra algo perennemente moderno. Más allá de la coincidencia o no con los calificativos, para los cuales en este caso tendría que explicitar su fundamento, la obra de Connolly puede ser considerada como una summa, con la unidad que le da, 
entre otras cosas, la figuración del propio autor, sin olvidar que sus fallas son también parte de su creación.

Me ocuparé ahora, más in extenso, de tres ensayos que están directamente relacionados con mis hipótesis: "Connolly's Unquiet” de Jed Perl; "Un gemido desde la tumba inquieta" de Edmund Wilson y "On not Getting on with it: The Criticism of Cyril Connolly” de Stefan Collini.

En cuanto a la forma en los libros de Connolly, Jed Perl es quien más aporta; la considera una elección y un acierto: "The broken, the fragmented, the impossibility of the traditional forms: these are of course preoccupations of the modern movement"; y a esta luz, no sólo la escasa obra fragmentaria, sino la pereza proverbial de Connolly, pueden ser consideradas como una respuesta a la grandeza de la literatura en su propio tiempo, nos dice. Asimismo, tomando una idea de Stephen Spender, Perl relaciona la forma adoptada por Connolly con su temperamento escéptico y perfeccionista, típico de los artistas del s. XVIII: "The eighteenth century was the time when a few essential artists began to accept the impossibility of any longer creating an all-encompassing work of art”. Formula la siguiente valoración sobre la forma breve:

With Connolly, the failure of all the grand ideas is itself an idea, even a central artistic imperative. To cultivate a fragment, to polish a little essay, to pour all the refinement of one's imagination into the brevity of a journalistic review: these are of course in some sense admissions of defeat, of an inability to do the big thing, to go all the way. But when embraced with the fullness of one's consciousness, the short forms, the ephemeral forms, even if we regard them as the falled forms, can also provide a way of grappling with the essential artifice of art, with the unnaturalness of creation, the anxiety that everybody intelligent feels as they construct essays and books, intellectual kingdoms meant to make relative order out of our relative confusion.

Acierta Perl al juzgar la forma breve, el gusto por la miniatura, la pereza, la ansiedad, el miedo al fracaso, no como fallas de su arte sino como el modo en que al fin lo forjó.

La misma vía estaba ya planteada por Edmund Wilson, que relaciona La tumba inquieta con la tradición francesa de les pensées de Pascal, La Rochefoucauld y Chamfort, en la que sin embargo nuestro autor ha encontrado una forma propia, nos dice, donde "hay temas que entran y salen de la trama de un modo más sinfónico que aforístico" (Wilson 636); juzga estos "ensayos breves" como "concentrados, exactos y lúcidos (sólo cuando el pensamiento -no el estilo- se pasea entre ideas generales, se vuelve a veces confuso)" (636). Seguiré la línea abierta por Wilson al considerar que existe una trama sinfónica en La tumba inquieta, donde ciertos temas (la literatura, el 
amor, la muerte, la religión) se contraponen y varían para resignificarse. Wilson detecta un gusto clásico en la colección de ensayos The Condemned Playground, no influenciado por las modas; un hombre que "lee, y escribe sobre lo que lee, porque encuentra en ello un pasatiempo agradable"; la literatura no como pretexto para la escritura sino un gusto que no se puede dejar de compartir (638); la apreciación es algo simple, pero sugiere la escritura del ensayo como desborde, como exceso que responde al texto reintegrándolo al deseo de escritura que estuvo en su origen. Si bien no juzga a Connolly un crítico de primera línea, en asuntos literarios le parece más acertado que otros que, teniendo más peso, apuntan "con un vocabulario jergoso, a analizarlos sociológica, estética o filosóficamente" (636); en la división amateurs-profesionales, pone el énfasis en el lado contrario al de Murat; en ambos casos me interesa cómo hacen patente el conflicto de discursos. Por último, afirma que cualesquiera sean sus faltas, el mismo Connolly las ha descrito mejor que nadie; es más, agrego, son su creación, la figura que creó para sus lectores. Dado que Edmund Wilson es un estricto contemporáneo de Connolly, y que, en tanto hombres de letras, la crítica los ha comparado, volveré sobre estas afirmaciones en el desarrollo de este trabajo.

Stefan Collini también opina que Connolly no está en la primera línea de los críticos, a la altura de T. S. Eliot y Edmund Wilson, como lo quiso Auden. Es más, afirma que Connolly se pensaba como escritor $y$, sin embargo, fue reconocido como crítico; caso extraño, dado que una parte muy pequeña de su obra "is literary criticism in the purest sense of that term: the sustained analytical attention to the verbal texture of particular works of literature” (10). Sostiene que fue un crítico en el sentido más amplio y residual del término:

he was someone who wrote about books but could not be described by other, more specialized labels - he was neither a poet nor, it finally turned out, a novelist, but nor was he a scholar in any professional or accredited sense, though he was extraordinarily knowledgeable across a wide range of subjects. He made his mark by writing about other writers' writing and his own not writing. (Collini 10)

Sin embargo, Connolly le parece una figura mucho más relevante que los demás editores literarios y críticos periodísticos de su época (Desmond MacCarthy, Raymond Mortimer, Philip Toynbee, Alan Ross, etc.), sitio que lógicamente le correspondería; conjetura algunas razones:

This may be attributable partly to the sheer quality of Connolly's writing, partly to the continuing life of at least two of his books (Enemies of Promise and The Unquiet Grave), and partly to the allure shed by his well-documented life. But it 
may also be that he has come to stand for a certain manner or ideal of writing for a so-called general audience. (11-12)

Perhaps one of the secrets of those whose literary journalism bears rereading is that they were always more than literary journalists. [...] But at his best, he [Connolly] did manage to suggest that his first-hand knowledge of the excitement and terror of writing gave him a more than purely routine claim on the reader's attention. (19)

Collini considera la reivindicación de Connolly como "the last of the men of letters" por parte de autores y críticos periodísticos que se identifican con esa figura como un desafío ritual a sus supuestos sucesores, el académico sobre-especializado y la celebridad supercomercializada (12). Y afirma:

'Littérateur' tends to be the label, not always flatteringly intended, given to someone who has put together a books-centred life while failing to get on with, or succeed in, a larger literary ambition. A 'would-be littérateur' sounds a bit like a trainee jack-of-all-trades or someone who aspires to be an understudy. (13)

Rescata Collini la intensa labor de Connolly en defensa del modernism. Mediante su crítica trató de educar al público para llegar al nivel de las obras más experimentales de su tiempo, y no a los escritores para descender al nivel del mercado. Este lugar problemático y móvil que ocupa Connolly -ni escritor ni académico- evidencia las tensiones sobre la función social de la crítica y sus discursos, que analizaré al establecer el lugar del hombre de letras en el campo literario.

Por último, apuntaré algunas ideas centrales de las reseñas más extensas que aparecieron en castellano con motivo de la publicación de distintos libros de Connolly.

Aun cuando existen diferencias de denominación, los críticos coinciden en cuanto a que el género practicado por Connolly es moderno, problemático y posee actualidad "porque sus libros y sus críticas son de la misma naturaleza literaria, son textos abiertos" (Garrido); no entran, para Danubio Torres Fierro, en las compartimentadas categorías conocidas (ensayo, autobiografía, crónica), “son libros estructuras peculiares, embalses elásticos, fronteras indecisas- que vehiculan y trasuntan una estrategia literaria, es decir, la constante escaramuza de la literatura con el mundo, del verbo escritural con la vida caudalosa" siendo, tal vez, "el único medio idóneo para imaginar un espacio de discusión del gusto, más allá de la publicidad o la academia” (Catelli 2005). 
Estos textos tienen una particularidad: la de poseer "una fuerte y seductora impregnación del yo, tan visible en muchas clases de estilos actuales" (Catelli 2005); terminan volviéndose textos literarios, donde "el autor acaba siendo un personaje actuando entre libros y anécdotas, y por ello transforma la deseada objetividad del crítico $[\ldots]$ en una mezcla de sagacidad y subjetividad biográfica que tiene un remoto antecedente en Montaigne" (Malpartida). Este personaje de sus textos, al que llamamos hombre de letras, se vuelve problemático en la práctica misma de su escritura, y así es como lo ve Christopher Domínguez Michael:

si "hombre de letras" se entiende por "crítico literario", estaríamos en riesgo de creer, como todavía lo afirman algunos manuales, que crítico literario es aquel que postula teorías literarias legitimadas por la academia. Yo pensaría al revés, por ejemplo, que el doctor F.R. Leavis o Roland Barthes fueron, además de profesores, importantes críticos literarios. (Domínguez Michael)

La imbricación entra la vida y obra de Connolly parece ser una obviedad, pero en ningún caso se analiza, se deja constancia que la vida, al pasar a la obra, es ficcionalizada; parte ya de la escritura, es consecuencia directa de un proceso de autofiguración del mismo Connolly. Así, las críticas dirigidas a los defectos y aciertos personales, no tienen en cuenta que se basan en el personaje que el mismo Connolly creó a través de su escritura; crítico, hombre de letras, littérateur, siempre está presente la figura creada por los textos mismos, y así puesta en circulación. Denostada por unos y elogiada por otros, su figura nunca es recompuesta y analizada a partir de las múltiples variaciones que sufre en los textos; a esto se agrega la dificultad de que escasa parte de su obra es autobiográfica en sentido estricto (III cap. de Enemigos de la promesa); así, su personaje se delinea en una multiplicidad de textos cuya misma heterogeneidad se vuelve problemática. Si tenemos en cuenta algunos estudios modernos, podrían quedar incluidos dentro de la amplitud y plasticidad del género ensayístico, que contempla la escritura de la subjetividad. Sin embargo, siendo que en estos ensayos se realizan muchas veces apreciaciones valorativas sobre libros y autores, deben establecerse las relaciones que mantienen con la crítica literaria y cuál es la legitimidad que ostentan en tanto apreciación de un hombre de letras.

Teniendo en cuenta estos antecedentes, analizaré la obra de Cyril Connolly a partir de las hipótesis de que sus ensayos constituyen un compuesto discursivo heterogéneo que, mediante la sumatoria de procesos de autofiguración y juicios valorativos, construyen la figura, opinión y el gusto de un hombre de letras que se propone una injerencia decisiva 
en un campo literario particular en el momento problemático en que este tipo de actor se ve sometido a las tensiones que propiciarán su desaparición; a su vez, esta obra constituye una intervención transgresora y polémica en ese universo literario al proponer como legitimidad última de la crítica la construcción subjetiva del crítico mismo. Así, por un lado, me propongo contribuir al conocimiento de la obra ensayística de Cyril Connolly -que, más allá de abordajes biográficos, no ha sido objeto de ningún extenso estudio-, en especial estableciendo los modos de autofiguración que permitan reconstruir un tipo particular de crítico y hombre de letras y explicando los múltiples relaciones que mantienen en su obra la autofiguración, el ensayo y la crítica literaria. Y por otro, entonces, contribuir al conocimiento teórico-crítico de las relaciones entre autofiguración y ensayo, y entre subjetividad y apreciación crítica en el ensayo literario.

Organizaré la escritura en cinco capítulos. En el primero me ocuparé de establecer a Cyril Connolly como "hombre de letras". Su obra es el resultado de múltiples tensiones; viene a insertarse en un momento de la tradición donde la crítica, debido a las manipulaciones mercantilistas de su público, se debate entre el amateurismo del humanismo literario y una profesionalización de escasa relevancia en la esfera pública. En la necesidad de explicitar la posición de Connolly en esa etapa crucial de la tradición crítica y ensayística inglesas, tomaré como base el estudio de Terry Eagleton, La función de la crítica, que precisamente se ocupa de su desarrollo en Inglaterra, configurando los tipos de críticos que la ejercieron y el carácter de su intervención social. También estableceré la figura del "hombre de letras", rastreando su historia, entre precursores y modelos, en Europa y luego en Inglaterra en particular, para arribar a una definición de este actor del campo literario. Una vez hecho esto me ocuparé de Connolly, y de algunos de sus contemporáneos, como ejemplares de los últimos hombres de letras.

El segundo capítulo abordará la figura de Connolly en tanto ensayista, dado que la heterogénea producción textual de Connolly, con su variedad temática, estilística y formal, se concretiza en los modos del ensayo; forma proteica -su misma concepción genérica lo es- puede considerársela un espacio privilegiado de tensiones. En el ensayista el crítico se confunde con el escritor, y viceversa, y sus relaciones con la lectura -que se vuelve escritura-, la comunicación de un estatuto de verdad, valor y experiencia, se tornan problemáticos, en tanto no accede a los protocolos de la teoría avalada académicamente. Este estudio tendrá como base el libro de Modos del ensayo, 
de Alberto Giordano, así como, para abordajes de algunos rasgos en particular, las propuestas de Eduardo Grüner, Walter Mignolo, y, en especial, los aportes de Graham Good y O. B. Hardison. Rastrearé los orígenes históricos del ensayo como género, para luego establecer sus características genéricas o "modos", con el fin de poder ver la particularidad de los escritos por Connolly.

En el tercer capítulo estableceré las relaciones entre ensayo y autofiguración en la obra de Connolly. Lo ensayístico como textualización permite el componente subjetivo y la comunicación de la experiencia; si bien el ensayo no se confunde con la autobiografía, admite apariciones o momentos autobiográficos; Connolly no sólo escribe su autobiografía al escribir sus lecturas, sino que la hace explícita para que sepamos quién lee y por qué las elige. Para la interpretación y análisis de los procesos de autofiguración me basaré principalmente en el libro de José Amícola Autobiografía como autofiguración, así como también en los aportes de Sylvia Molly y María Teresa Gramuglio.

En el cuarto capítulo, asentado sobre las bases de los anteriores, haré un análisis detallado de las dos obras mayores de la producción de Connolly, Enemigos de la promesa y La tumba inquieta, para ver en qué particular manera se relacionan la reflexión, el juicio estético y la autofiguración, vinculando estos textos singulares con la tradición de crítica ensayística y el concepto de fragmento; para establecer esto me basaré en el libro de Lacoue-Labarthe y Jean-Luc Nancy sobre teoría de la literatura en el romanticismo alemán.

Por último, en el quinto capítulo, me ocuparé del papel que tiene la crítica en la formación del valor literario, y cuál es el papel del yo en la valoración del arte en tanto ejercicio de un gusto, una forma problemática de; aquí se tendrán en cuenta los trabajos de Pascale Casanova y de Bourdieu (El sentido social del gusto); postulados de Barthes en su última etapa crítica, donde aboga por un retorno de lo subjetivo, de Alberto Giordano y Juan José Saer; y las reflexiones de Raymond Williams y Giorgio Agamben sobre el gusto. 


\section{Cyril Connolly, hombre de letras}

\subsection{Hombre de letras: problemática y amplitud del concepto}

Existe, por lo menos, un punto de unanimidad en torno a Cyril Connolly: fue un hombre de letras. Esta caracterización principal, sin embargo, requiere cierta precisión conceptual, un límite de significados, a riesgo de una generalidad que nada defina. La construcción, difícil de documentar, proviene del francés homme de lettres. En todos los casos que, en primeras instancias, podemos consultar, prima esta generalidad e imprecisión del concepto: "écrivain, littérateur" (Larousse); "a learned man, scholar, a literary man, author, littérateur" (Webster's); "el que cultiva la literatura o las ciencias humanas" (DRAE). Sobre estos mismos matices nebulosos abunda T.S. Eliot (1888-1965) en su ensayo "Los clásicos y el hombre de letras"1; la expresión es "bastante imprecisa", además de una "modesta pretensión", aclara (Eliot 193); las palabras poeta, novelista, autor teatral, sugieren técnicas más específicas y una labor solipsista. Pero para seguir adelante con los planteos de su alocución le conviene esta expresión, y es por eso que trata de aproximarse a alguno de sus significados:

[Hombre de letras] Abarca a hombres de segunda y tercera fila e incluso a los de categorías inferiores, así como a las máximas figuras; porque esos escritores secundarios, colectivamente y en diversos grados individualmente, forman una parte importante del medio ambiente en que se mueve el gran escritor [...] La continuidad de una literatura es esencial para su grandeza; en muy gran medida es función de los escritores secundarios preservar esa continuidad. (195)

Sin encasillar a Connolly en esa segunda fila ${ }^{2}$, podemos decir que ocupa un lugar en el campo literario que, sin producir literatura de ficción, crea un cuerpo de obra que sirve de eslabón y medida para poder leerla y sopesarla.

El crítico y editor Andreu Jaume, en la "Introducción" a la Obra selecta (2005) de Connolly, precisa, y aprecia, otras aristas del término que, por sumatoria y matices, afianzan y amplían sus contenidos:

Una figura muy común en Inglaterra y que en España es más rara, el man of letters, el hombre de letras ajeno a la universidad, que vive de rentas o de una profesión que nada tiene que ver con la literatura o malvive -caso del propio Connolly- de colaboraciones periodísticas, dueño de un gusto muy particularizado, una autoridad cívica, en fin, que representa la cúspide de una sólida clase lectora para la que habla sin sentirse desesperadamente solo. (Jaume 10)

\footnotetext{
${ }^{1}$ En todos los casos en que exista traducción castellana de los textos utilizados, me atendré a ésta. En caso contrario, utilizo el original en inglés. "The Classic and the Man of Letters", alocución presidencial en la Asociación Clásica de Cambridge, 15 de abril de 1942.

${ }^{2}$ Cyril Connolly afirmó alguna vez que "tan sólo sería recordado por haber ido al colegio con George Orwell y a la universidad con Evelyn Waugh" (Jaume 9).
} 
Una figura que en España y Argentina es, más bien fue, rara, y que el mundo anglosajón enfrenta con nostalgia o desdén, según las batallas libradas, dado que, en la segunda mitad del siglo pasado, los 'últimos' hombres de letras fueron defendidos o vilipendiados como supervivientes de una práctica en decadencia. La profesionalización de los estudios literarios (históricos, políticos, económicos, etc.) señalaba como triviales o apenas pintorescas las apreciaciones experienciales, caprichosas, estilísticas, de los diletantes; sus voces, largo tiempo altisonantes en la esfera pública, fueron cuestionadas en su legitimidad.

Sobre el tema existe un libro clave, de título prontamente clarificador: The Rise and Fall of the Man of Letters. English Literary Life Since 1800. A pesar de dedicar la obra enteramente al tema -quizá para no limitar inclusiones, quizá por no enfrentar la inestabilidad del concepto- John Gross no define su objeto. Sin embargo, en el prefacio realiza un sintético recorrido por su mutabilidad referencial, que me permito citar de forma completa:

Originally the term [man of letters] denoted a scholar; then it gradually came to be applied to authors in general. By 1840 Carlyle was able to talk about the Hero as Man of Letters, acclaiming him as 'our most important modern person'. After this, however, the meaning began to be narrowed down. A generation later, it was still possible to call a new series of books about poets, playwrights and novelists English Men of Letters, but only just; the idea already seemed faintly pompous or absurd. By this time a man of letters was very definitely coming to suggest a writer of the second rank, a critic, someone who aimed higher than journalism but made no pretence of being primarily an artist. Up until the First World War men of letters in this sense were a familiar part of the literary landscape; then the term fell into disrepute. (Gross 9)

La misma laxitud conceptual que a Gross lo habilita al rescate y posicionamiento de una amplia gama de escritores ingleses de los siglos XIX y XX, le sirve a Robert M. Adams para hacer una enumeración inclusiva que, si intenta ser denigratoria, no deja de mostrar la variedad de prácticas culturales asociadas al hombre de letras:

The man of letters might be a lecturer, a satirist, a reviewer, an essayist, an editor, a columnist, or an entertainer; occasionally, he appeared as a translator, a biographer, a popularizer, a contributor to encyclopedias and other collections of useful knowledge; he might be an anthologist or a commentator on literary trends. One of his more familiar roles is that of literary critic or historian. [...] But to the extent that any particular profession came to predominate, he was less recognizable as a man of letters, whose characteristics are peculiarly unfixed and indeterminate. (Adams 100) 


\subsection{Orígenes y antecedentes. Una tradición europea}

Aplicar el término 'hombre de letras', más propio de la Ilustración y el auge del periodismo, a escritores de épocas anteriores pudiera ser de dudosa precisión; cualquier escritor de temas intelectuales no vinculado a una ciencia, a un método o a una institución específicos bien podría quedar incluido. Sin embargo, aprovechando su escasa discriminación, me permito establecer sus posibles precursores, hitos que permitan afianzar el devenir de una práctica determinada.

En mi opinión, el candidato más acreditado de la antigüedad occidental sería Aulo Gelio (c.130-c.180). Durante el s. II de nuestra era, el conjunto de la obra ciceroniana sienta las bases para el desarrollo de la noción de humanitas, "entendida como fijación del hombre en el centro de atención y el interés por los estudios literarios siguiendo los modelos antiguos" (López Moreda 14); el hombre como individuo y no ya ente indeterminado o definido por su vínculo con la polis, ocupa un lugar eminente en los valores culturales. Dado que lo específicamente humano es la palabra, el lenguaje y su estudio son el centro de atención de cualquier propuesta educadora; existe la confianza en que el control de esta herramienta, estabilizada en los modelos considerados clásicos, es el vehículo perfecto para la adquisición del conocimiento y la cultura en general. El hombre culto debía adentrarse en el estudio del pasado y las 'artes liberales' -es decir, no serviles-: el derecho, la historia, la filosofía y la literatura; pero tenía que hacerse también con las materias del más tarde llamado Trivium, la gramática, la dialéctica y la retórica. La lengua es vehículo de conocimiento, y es objeto de estudio; más estilo que expresión, materia densa de trabajo para el artifex.

A mediados del s. II, en las noches gélidas de la península Ática, Aulo Gelio ordenaba apuntes de las varias cosas que despertaban su curiosidad. Había nacido en Roma, hijo de una familia acomodada, y estudió gramática y retórica con los mejores profesores de su tiempo; su viaje a Grecia queda comprendido en el curso de su esmerada formación intelectual. Allí estudió filosofía y frecuentó residencias de verano, conversando sobre distinguidas y antiguas cosas por los jardines. De regreso en Roma tuvo esporádicos desempeños como juez, pero le interesaron más la erudición y los orígenes jurídicos que el ejercicio de su cargo.

El sentimiento de cerrada pertenencia que otorgaba la nobleza romana dentro de la república se debilitaba, porque en el imperio los provincianos, y hasta libertos, ocupaban altos cargos en la administración. Los intelectuales, que apenas colaboraban 
con el poder, se cohesionaron en un nuevo grupo social de élite. Los temas que en las Noches áticas se tratan no tienen finalidades prácticas ni didácticas, están alejados de los intereses y conocimientos del hombre común; se trata de notas y comentarios dispersos sobre gramática, derecho, historia y literatura, sobre la Roma germinal, objetos del deseo para diletantes eruditos que ocupan su ocio en la curiosidad intelectual. Recuerdos de amables conversaciones, escritas con aparente descuido, que tienen por finalidad el literario entretenimiento de sus hijos -y gente como ellos- que, descansando de las ocupaciones diarias, pueden así adquirir conocimientos mediante el placer de la lectura sin el rigor del estudio. Digamos, sin embargo, que estas erudiciones se proponen tanto deleitar como instruir.

El ciudadano capaz de aprovecharse de estos saberes es, obvio, el letrado; por tanto, en sus orígenes, existe un grupo escaso de hombres de letras que se definen por su oposición al iletrado, un espacio público reducido y bastante coherente de circulación de conocimientos, donde la erudición en las artes liberales, la lengua y las antiguas instituciones los vincula a una tradición a la vez que los separa del vulgo y los bárbaros incorporados al imperio. El humanismo parte de cierto acuerdo en los saberes tradicionales compartidos:

Quienes crearon los términos latinos y quienes los emplearon correctamente no quisieron que humanitas significara eso que el vulgo cree, que se conoce en griego como "filantropía", y que significa cierta habilidad y benevolencia para con todos los hombres sin distinción, sino que llamaron humanitas más o menos a eso que los griegos llaman paideia, y nosotros conocemos como "instrucción" y "formación" en las buenas artes. Quienes desean éstas con sinceridad y tratan de adquirirlas ésos son, con mucho, los más humanos. En efecto, el interés y la enseñanza de esta ciencia, de entre todos los seres vivos sólo al hombre le han sido concedidos y por eso se llama humanitas. (Aulo Gelio XIII, 17, 1)

Lo que hoy llamamos 'humanismo' es un movimiento cultural ligado al Renacimiento, y la mayoría de los autores allí encuadrados fueron admiradores de Aulo Gelio. Si bien no podemos decir que Dios queda totalmente desplazado, no ocupa en esta época el lugar preeminente que tuvo durante la Edad Media, no está omnipresente en las especulaciones intelectuales. El antropocentrismo propugna un renacer de aquellos valores grecolatinos y los humanistas vuelven sus miradas a la antigüedad clásica, sus lenguas y literaturas, en busca de una ampliación de lo humano más allá de las Sagradas Escrituras y el fundamento único del pensamiento religioso; los nuevos valores preponderantes son el hombre, la razón y la lógica, la tolerancia religiosa y cultural, la confianza en el crecimiento del hombre mediante la formación. Dante (1265-1321), 
Petrarca (1304-1374) y Bocaccio (1313-1375), más allá de sus obras literarias, fueron estudiosos e intérpretes que instalaron la antigüedad clásica en el centro de la vida cultural de la península itálica; el Discurso sobre la dignidad del hombre (1486), de Giovanni Pico della Mirandola (1463-1494) -quien fuera el primero en utilizar la palabra 'humanismo' para referirse a este movimiento-, puede considerarse un manifiesto del pensamiento renacentista; otros autores destacados son Lorenzo Valla (1406-1457) y Erasmo de Rotterdam (1466-1536). Esta confianza en el individuo -y su experiencia-, en la formación clásica y en la letra, tuvo su apoteosis en el francés Michel Eyquem de Montaigne (1533-1592), a quien considero como el precursor más acabado del hombre de letras moderno. Siendo mayúsculos sus aportes a este estudio, me ocuparé de ellos en el siguiente capítulo.

No existen demasiadas dudas acerca del prototipo del hombre de letras: Charles Augustin Sainte-Beuve (1804-1869) ${ }^{3}$. Criticado por casi todas las corrientes críticas del s. XX, ejerció un dominio indiscutible en el campo literario durante el s. XIX; además, se encontraba en el momento y el lugar propicios: París, capital de la recién consolidada República Mundial de las Letras ${ }^{4}$. En su primera juventud comenzó estudios de medicina, que enseguida abandonó para entrar a los veinte años en el periódico Le Globe y dedicarse enteramente a la vida literaria. Tuvo estrecha amistad con Victor Hugo (1802-1885), centro del campo literario francés de la época romántica; pero más páginas ocupa su ruptura, que no se limitó al campo estético. Hugo: la figura inmensa, universal, el creador todopoderoso, poeta y novelista afamado, amante de éxitos

\footnotetext{
${ }^{3}$ Si bien no me detendré en este tema, que sólo toca tangencialmente a mi estudio, y que requeriría de problematizaciones sociológicas e históricas de los campos literarios específicos, cabe destacar la existencia e importancia de las femmes de lettres. Durante los siglos XVII y XVIII, en Francia, ciertas mujeres cultivadas e influyentes mantuvieron en sus casas 'salones literarios' que nucleaban a los intelectuales y artistas de la época. El mismo Sainte-Beuve incluyó en sus Retratos literarios las semblanzas de algunas mujeres, entre las que cabe destacar a Mme. de Sevigné, Mme. de La Fayette, y Mme. de Pontivy. Habría que destacar aquí también la importancia política y literaria de una figura como la de Mme. de Staël. Sin embargo, hasta bien entrado el s. XX, el término arrastró un cariz despectivo del que siempre careció su par masculino. En Inglaterra la figura señera de Virginia Woolf, paralela a la profesionalización de algunas escritoras, hizo mucho por el prestigio de las mujeres de letras.

${ }^{4}$ Según Pascale Casanova: "A finales del siglo XIX, a comienzos del XX, Francia, en gran medida a remolque de la Europa económica, es el centro indudable de la literatura y la pintura de Occidente" (citando a Fernand Braudel; 23); y luego: "La constitución y el reconocimiento universal de una capital literaria, es decir, de un lugar donde convergen el mayor prestigio y la más grande creencia literarios, derivan de los efectos reales que produce y suscita esta creencia. Existe, pues, dos veces: en las representaciones y en la realidad de los efectos mensurables que produce. París se convirtió, por tanto, en la capital del universo literario, la ciudad dotada del prestigio literario más grande del mundo" (40). Quien esté interesado en ampliar el tema puede consultar París, capital del siglo XIX de Walter Benjamin.
} 
numerosos; Sainte-Beuve: el escritor frustrado, árbitro reconocido, lector voraz, gordo, misántropo y soltero, que vive con su madre. Si en el campo literario las rivalidades tienen por objeto la literatura (Casanova 25), el ganador es quien pone nombre a la obra que se hace depositaria de un capital de valor literario; Sainte-Beuve puede ser algún tipo de juez, ayudar a repartir los premios, pero no puede ser protagonista, depositario de la fama, encarnar el valor que ansía. Por tanto, el adulterio que comete parece tener bastante de simbólico y hasta de sustitutivo: aprovechó la amistad de Hugo para seducir a su esposa Adèle, como si pudiera hacerse así con las musas del gran escritor. Una historia, casi una alegoría, de amor, envidias y desencuentros tanto en la vida como en la literatura.

A Sainte-Beuve, a diferencia de sus precursores antes mencionados, le toca escribir en una época donde la alfabetización y la prensa acrecientan el número de lectores; la aproximación de otras clases sociales al consumo y el debate sobre los bienes culturales intensifica la labor del crítico en el establecimiento de los valores que, si no inestables, son por lo menos materia de discusión en un espacio público que se piensa cada vez menos coherente. Ejerció su función desde púlpitos diversos: Vida, poesías y pensamientos de Joseph Delorme (1829) y su novela Voluptuosidad (1835), si bien demostraban probidad literaria, no obtuvieron la repercusión esperada; tempranamente había tenido mayor éxito con Cuadro histórico y crítico de la poesía francesa y del teatro francés del Siglo XVI (1828), y alcanzó su fama crítica con la que es considerada su obra maestra Port-Royal (1840-1859, cinco volúmenes basados sobre conferencias que había dado previamente en la Academia de Lausana; describe la historia de la abadía de Port-Royal-des-Champs, cuna del jansenismo, desde sus orígenes hasta el momento de su destrucción); fama que se vería acrecentada por sus diversas series de Retratos y sus célebres Charlas del lunes, que escribió una vez por semana, durante más de veinte años, para el periódico Le Constitutionnel. Fue, además, miembro de la Academia Francesa de Letras - paradójicamente, fue Victor Hugo quien lo recibió- y, al final de su vida, senador del Segundo Imperio.

Sainte-Beuve ejerció lo que llamaremos, tomando el término de Albert Thibaudet, la "crítica periodística", que ya a principios del s. XIX es un rival no siempre cordial de la "crítica de la cátedra", que se crea y ejerce desde la Universidad, la Facultad de Letras, la Escuela Normal ( Thibaudet 81 ) $^{5}$. Su método, algo simplificado,

\footnotetext{
${ }^{5}$ Poco más adelante veremos cómo en Inglaterra se desarrolla este mismo conflicto, de manera más tardía.
} 
se basa en la búsqueda de las intenciones poéticas del autor y en la creencia de que ciertas cualidades personales suyas ayudan a explicar la obra; es por eso que llevó más lejos que nadie quizá el arte del retrato literario. Esta noción de cierto reflejo entre vida y obra -imposible de desterrar de la literatura, por más teorías en alza o en baja que la hayan denostado- es la crítica más constante que recibe Sainte-Beuve; Marcel Proust trató de escribir un libro específico que criticara esta postura, Contra Sainte-Beuve (publicado en forma póstuma, se puede apreciar como un germen de su futura obra maestra); le siguieron formalistas, estructuralistas $\mathrm{y}$, en general, todos los tipos de crítica teórica. Otro reproche que sus colegas posteriores le han hecho a su capacidad crítica es el de haber menospreciado la obra de algunos contemporáneos que hoy son clásicos, como Stendhal, Balzac y Baudelaire.

La función pública de crítico literario que cumplió Sainte-Beuve, si bien ambas no se confunden, está impregnada de su vocación moralista ${ }^{6}$. Se reconoce como heredero de una tradición muy fuerte en Francia, de figuras de la talla de Montaigne, La Rochefoucauld, Pascal, La Bruyère, Voltaire y Chamfort ${ }^{7}$.

Tanto o más que una mirada sobre la literatura, que una encuesta sobre los autores, la crítica de Sainte-Beuve debe considerarse como una información sobre el hombre y las mujeres, sobre sí mismo y sobre los otros, sobre las naturalezas de espíritus y sobre el espíritu de la naturaleza humana. Todo el contenido humano de las letras francesas va a dar a este humanismo, como el mundo de los sonidos, de las palabras y de los ritmos va a dar a Victor Hugo. (Thibaudet 245)

Se inició en el campo de las letras durante el auge del romanticismo, de cuyos experimentos luego renegó para internarse en un modelo crítico que busca el ideal del equilibrio ante la errancia de las formas; este ideal estético, y la responsabilidad moral que exigía, lo llevaron al establecimiento de un canon que obturó su mirada ante ciertos desafíos poéticos contemporáneos hoy indiscutidos, clásicos. El conjunto de su obra conforma una summa de quien fuera en su medio un detallado connoisseur de las costumbres, del ethos literario, un campo que gana en autonomía y va estableciendo la particularidad de sus leyes. Podría decirse que la magnitud de su obra es a la vida literaria lo que la Comedia humana de Balzac es a la novela.

\footnotetext{
${ }^{6}$ Moralista no en cuanto a defensor de una moral, sino por la crítica de las costumbres (mores en latín) que lleva a cabo en su obra.

${ }^{7}$ Cyril Connolly, como veremos en su libro La tumba inquieta, se sentía heredero de los mismos autores, además de heredero de Sainte-Beuve.
} 


\subsection{El hombre de letras en la tradición inglesa}

Cyril Connolly fue como lector y como crítico un entusiasta de la literatura francesa, y cita con profusión a Sainte-Beuve en La tumba inquieta; hasta llega a escribir: "Intensa emoción, una mezcla de alivio y desesperación, al leer el cuaderno de Sainte-Beuve Mes Poisons y descubrir: "Este soy yo" (Connolly 2005: 471).En un artículo sobre la vida del crítico francés afirma: "He was a classicist and in his studies of the seventeenth and eighteenth century he is unsurpassed. He was the inventor of modern criticism and one of the most agreeable essayists of all time" (Connolly 1963: 179).

Sainte-Beuve fue modelo manifiesto de muchos hombres de letras ingleses; y el afianzamiento de este actor en el campo literario inglés fue productivo para una tradición que podemos ver como pródiga en la fama que otorga a sus hombres de letras. Según Terry Eagleton, la irrupción de la crítica en Inglaterra está directamente asociada a la lucha contra el Estado absolutista; dentro de ese régimen represivo comienza a formarse, durante los siglos XVII y XVIII, un espacio discursivo diferenciado que se sustenta sobre la base del juicio racional y la crítica ilustrada. Entre el Estado y la sociedad civil se forma lo que, siguiendo a Jürgen Habermas, Eagleton llama "esfera pública" (Eagleton 11): entramado burgués donde ciertas instituciones (gacetas, periódicos, clubes, cafés, etc.) se consolidan como espacios idóneos para que un grupo de individuos ponga en circulación un intercambio libre e igualitario de discursos racionales; se nuclea así un cuerpo de relativa coherencia capaz de funcionar como fuerza política. En una sociedad monárquica altamente compartimentada, y de privilegios que la antigüedad solidifica, la esfera pública burguesa legitima a los sujetos no ya por poder o tradición, sino a través de su capacidad para sostener discursos y discusiones sobre la norma de la razón universal. El optimismo derivado de esta liberalidad acrecienta la convicción de que una opinión pública educada tiene inmunidad suficiente para resistir los dictados del poder.

Por tanto, en esta etapa, la crítica cumple una función donde la comunicación efectiva con el público es parte esencial del sistema. La reflexión privada y poética de los cortesanos se convierte en discurso público; captar la atención del lector e instruirlo, persuadirlo y sumarlo al debate, son preocupaciones determinantes. El ensayo de las publicaciones periódicas, donde en un principio el autor se expresaba bajo seudónimos, personajes y cartas de lectores imaginarios, buscó un estilo ligero y despreocupado que fue sello del género. La crítica cumplía una función didáctica en la vida social y cultural que buscaba establecer las maneras y el gusto en un cuerpo comunitario que intentaba 
aglutinarse alrededor de valores y discursos comunes. La naciente clase media inglesa no busca una escisión política radical con la aristocracia decadente, dado que comparten intereses económico-mercantiles; para complementar esta alianza intentan hacerse también con los bienes culturales que habían sido prerrogativas de las clases altas. En este sentido, el debate literario no se presenta en el terreno de la estética; se valora la literatura en tanto modo de afirmación de nuevas demandas así como de apropiación de códigos y prácticas necesarios para posibilitar el intercambio.

En 1709 el irlandés Richard Steele (1672-1729) funda la revista The Tatler, donde colaborará Joseph Addison (1672-1719); dos años después suspende su aparición y ambos amigos crean The Spectator, que salió hasta 1712. El ingenioso Steele y el culto Addison entablan así una amistad que durará hasta la muerte de este último; más allá de sus obras particulares, la historia literaria ha preservado sus nombres como el de una dupla de fecunda colaboración, cuyo logro más recordado fue iniciar esta tradición tan cara a las letras británicas: "la de hojas periódicas publicadas por ensayistas" (Bioy Casares XII). Una amplia variedad de temas informa ambos periódicos ${ }^{8}$, dando cuenta, en estilo llano y accesible, de las 'buenas costumbres' de la nueva alianza inglesa.

El rasgo distintivo de la esfera pública inglesa es su carácter consensual: The Tatler y The Spectator son los catalizadores de la creación de un nuevo bloque dirigente en la sociedad inglesa, que cultivaron a la clase mercantil y ennoblecieron a la disoluta aristocracia. Las hojas de estas publicaciones (de aparición diaria o tres veces por semana), con sus cientos de imitadores menores, dan fe del nacimiento de una nueva formación discursiva en la Inglaterra posterior a la Restauración, una comunicación intensiva de valores de clase que "fusionaron las mejores cualidades del puritano y el caballero" (A. J. Beljame) y "modelaron un lenguaje para las normas comunes del gusto y la conducta" (Q. D. Leavis). (Eagleton 13)

La crítica que se practica en estas revistas no es crítica profesional, como se la entiende ahora; no se trata de un discurso especializado autónomo sino de reflexiones particulares que carecen de estructura teórica y/o de principio alguno que las rijan. Los autores mismos, en su afán inclusivo, se resisten a la especialización y frecuentan con familiaridad todas las ramas del saber. La crítica literaria se encuentra subsumida, sin diferencias aparentes, en la crítica cultural; un discurso civilizado pero amateur, donde el escritor hace las veces de camarada, portavoz de los caballeros dignos de pertenecer

\footnotetext{
${ }^{8}$ Entre ellos, según panorámica de Adolfo Bioy Casares: "la locura de las mujeres que se casan por dinero o que prefieren los deberes sociales a los hogareños, la decadencia de la oratoria sagrada, la estupidez de los maridos que tiranizan a sus mujeres y de los padres que tiranizan a sus hijos, los deleites de la vida de campo, los peligros que acechan a las niñas en el uso de prendas vistosas o en la lectura de novelas, la tontería de los duelos, el abuso del título esquire, las molestias ocasionadas por los estafadores, la incertidumbre de los juegos de azar, etcétera" (XIV).
} 
al club, iguales frente a la razón. Así, acompañando las ideas de Eagleton, puedo decir que se libera "la definición de caballero de todo rígido determinante genético o específico de una clase social" (31); en un intercambio por fuera de los intereses materiales en común, encuentran deleite en el ejercicio del gusto y las maneras que los muestran como iguales.

Al dejar de lado las insalvables distancias entre lo innato y lo adquirido, 'casi' cualquier hombre puede ser, mediante el aprendizaje y el despliegue del discurso y las costumbres adecuadas, un caballero; y, también, un crítico. La crítica detenta una superioridad porque es vehículo de lo correcto, del 'deber ser', y esa superioridad comienza a ser tolerable desde el momento en que se convierte en un espacio democrático, gentil, en cuanto que todos los hombres poseen, potencialmente, la capacidad de ejercerla; y la voz del crítico se eleva como mediadora, vehículo de lenguajes que recibe pero no inventa. Su ausencia misma de especialización remite su saber a la experiencia y los intercambios generales, dado que el "crítico no es en nuestro sentido un intelectual: en el siglo XVIII, como comenta Richard Rorty: 'Había hombres ingeniosos, hombres cultos y hombres piadosos, pero no había eruditos"' (Eagleton 27).

Alrededor de la década de 1730 comienzan a decaer las relaciones de mecenazgo y se da un incremento paralelo del poder de los libreros (35); los avances técnicos en la edición, un cada vez más extendido acceso a la educación, una reciente clase media lectora, dan como resultado una ampliación del exiguo público de las décadas pasadas y el advenimiento de una nueva casta de escritores profesionales para sostener la afición. A las exitosas revistas de Addison y Steele les sucede la menos explosiva pero igualmente famosa The Rambler, escrita enteramente por quien fuera el más famoso de los hombres de letras ingleses, el Dr. Samuel Johnson (1709-1784). Sin detenerme en detalles sobre su vida ${ }^{9}$, podemos decir que el Dr. Johnson, poeta, lexicógrafo, crítico, biógrafo, representa un caso paradigmático de las letras inglesas: es un autor distinguido, aunque menor, pero un hombre de letras mayor; tanto que es el escritor más citado después de Shakespeare en su idioma, y su época se conoce como la 'era Johnson'. Siendo cada vez más patentes las fuerzas del capital en los modos de producción cultural, Eagleton considera que el particular estilo de Johnson puede ser interpretado como una forma de resistencia (36); obligado a sustentar su seguridad material dentro del mercado, el crítico se desquita con un estilo tan individual como una

\footnotetext{
${ }^{9}$ El Dr. Johnson es objeto de la biografía mayor de la literatura: Vida de Samuel Johnson (1791), de James Boswell (1740-1795).
} 
marca registrada; al estilo llano y cortés y la camaradería práctica de Addison y Steele les sucede la elegancia latinizante de la prosa de Johnson y su abstracto didactismo moral. Si la esfera pública burguesa aún no se disuelve, sufre una gradual desintegración; los intereses comerciales privados ponen en peligro el consenso basado en el refinamiento y la razón; el ideal del caballero como interlocutor universal no resiste ante la incorporación de nuevos actores en la vida pública; la ilusión de homogeneidad se desvanece. Si bien el estilo de Johnson es más rebuscado, abstracto e introspectivo que el de sus antecesores, sigue considerando que

el acto de la crítica literaria no habita en una esfera estética autónoma, sino que pertenece de manera orgánica a la "ideología general", es indisociable de los estilos comunes del juicio y la experiencia, está estrechamente ligado al Lebenswelt que precede y engloba todas las distinciones disciplinarias especializadas. (Eagleton 39)

Los procesos desatados por la Revolución Industrial hacen patente una lucha de clases cada vez más enconada; las amenas, ligeras revistas del pasado donde se arbitraba sobre las costumbres y el buen gusto son reemplazadas por el partidismo, la virulencia, el dogmatismo de revistas como Edinburgh Review y Quarterly Review. Lo que surge así es una "contraesfera pública" (41) que batalla para destruir desde dentro el consenso dominante. En consonancia, la crítica se vuelve explícitamente política; como un extremado intento de rescatarla de esas luchas es que surge lo que Eagleton llama el "sabio" del s. XIX, que, imbuido de una estética idealista importada de distintos lugares del continente, trata de hacer de la crítica una forma trascendental de conocimiento. Privado de un público conocido, de un sujeto familiar al que dirigirse, el crítico romántico es el poeta que reflexiona sobre su arte; la literatura, sobre todo la poesía, es vista -siempre y cuando se mantenga ajena a las luchas políticas- como un discurso privilegiado, depositario de una posible sabiduría sobre lo humano que trasciende el devenir histórico. Los críticos y poetas románticos, como Coleridge y Carlyle ${ }^{10}$, se niegan a subordinar el juicio crítico al prejuicio político; no pudiendo ya igualmente sustentar sus reflexiones sobre normas públicas válidas, elaboran un intrincado discurso estético y filosófico del arte que reflexiona sobre sí mismo, lejos de las ataduras del sentido común. Se instaura así, de manera paulatina, la posibilidad de que la literatura

\footnotetext{
${ }^{10}$ Los críticos románticos son también poetas, y elaboran sus pautas a partir de un conocimiento explícito del arte mismo: "El crítico romántico es, en efecto, el poeta que justifica ontológicamente su propia práctica, que elabora sus implicaciones más profundas, que reflexiona sobre los fundamentos y las consecuencias de su arte" (Eagleton 48).
} 
sea un discurso autónomo, independiente de las lógicas que rigen otros intercambios sociales; es la época primera del arte por el arte.

En la transición entre siglos de la Inglaterra victoriana, donde aún se mantenía cierto recelo ante el ejercicio del periodismo, el que fuera practicado por ensayistas y críticos de la categoría de Charles Lamb y William Hazlitt le confiere cierta dignidad; sobre la mitad del s. XIX el periodismo literario ya era visto como una buena profesión para los talentos surgidos de las universidades. En su libro On Heroes and HeroWorship (1840), después de considerar variedades de héroes que considera extinguidas -la divinidad, el profeta, el poeta, el sacerdote-, Thomas Carlyle (1795-1881) reflexiona sobre su equivalente moderno, al que considera la más importante de las figuras contemporáneas: el héroe como hombre de letras (Gross 38). Con su equiparación de religión y literatura, Carlyle intentó elevar la vida literaria a una trascendencia capaz de sustituir lo real; intentó ser un artista tan grande como Goethe. No lo logró, y, si bien la entronización del hombre de letras tiene algo de autoglorificación, también es cierto, como marca Gross, que supo Carlyle, cual buen artista, transformar una neurosis privada en un mito público significativo (39). Su logro fue dar entidad significativa a una práctica que por sí misma, en una de sus variantes, pudiera parecer que carece de todo heroísmo; después de todo el hombre de letras no pasa de ser, a veces, el comentador de los libros que otros hombres escriben. Lo que lo diferencia, sin embargo, del mero propagandista, es la potencia de su estilo, una diferencia específica en la conciencia de la palabra y el texto como material artístico, lejana a la creencia de que la lengua puede ser sólo el medio con el cual las ideas preconcebidas pueden plasmarse por simple reflejo.

Acorde con la poética romántica, Carlyle buscó encarnar un ideal de totalidad, dando primacía al valor de integridad, una integridad trascendente donde el héroe, el hombre de letras, o el sabio, porta en sí la última garantía de un saber inapelable. Íntegro en su personalidad, íntegro el poema, la producción literaria no establece diferencias genéricas significativas porque, en última instancia, son emanaciones de un mismo genio creativo, y llevan, en consecuencia, el sello de su estilo y su visión. Gross hace una crítica retrospectiva de la producción de Carlyle: "he lacked the necessary patience for a sustained effort 'to see the object as it really is ", (47); su apreciación, que considera que el objeto es algo en sí mismo, y que, por tanto, ese ser puede aprehenderse objetivamente, podría dirigirse más a las ideas filosóficas generales que sustentaron la labor de Carlyle, que a Carlyle mismo; siente que su producción es 
demasiado apasionada, demasiado subjetiva, y que su real necesidad de dramatizarse nublaba su visión de los objetos analizados.

Estricto contemporáneo de Carlyle, Matthew Arnold (1822-1888) es otro de los hombres de letras cuya fama es todavía productiva en la tradición; tomándolo cual tipo ideal, se podría decir que encarna un modo de vida que puede llamarse 'Oxford'. Su apelación al 'gusto' transparenta que, en fin, las cuestiones de gusto son cuestiones de moralidad, síntomas de los valores por los cuales los hombres viven. Arnold, identificado con la cultura de las viejas universidades, con las clases educadas y sus valores $^{11}$, considera, sin embargo, que hay otra élite cultural más importante, hecha de individuos que sólo se encuentran unidos por su común 'love and pursuit of perfection', que para él nacen en todas las clases, y eso los eleva por encima de ella (69) ${ }^{12}$. Se presenta así una paradoja aparente que desde entonces viene siendo un tema de debate obligado en la crítica: la dificultad de conjugar liberalismo político con elitismo cultural. Acusado de ser poco democrático en sus estándares sobre lo que la cultura y la crítica son, Arnold afirma que, después de todo, el arte y los artistas no son democráticos. Padecen de un orgullo espiritual y cultural, el que les otorga el subordinar todas las demás virtudes a un ideal de excelencia artística (70). En el artículo que Matthew Arnold escribe sobre Sainte-Beuve para la Encyclopaedia Britannica afirma que hay hombres que alcanzan un grado tan cercano a la perfección en su quehacer que los demás deberían tomarlos por sus voceros; para él ese es el caso de Sainte-Beuve en el campo de la crítica. Estos nombres se hacen así depositarios de una creencia que otorga a sus opiniones una autoridad que en último término se fundamenta en la rúbrica. Épocas determinadas, campos determinados, sostienen características específicas y variables sobre lo que el hombre es y debe llegar a ser; mientras cierto tipo de humanismo funciona como creencia legítima, se piensa en la posibilidad de un Hombre Universal, ideal al que ciertos hombres se aproximan. Para Carlyle, en consenso con su época, Goethe era el hombre. El hombre de letras, como héroe, era un humanista.

Por un lado, entonces, tenemos al escritor de las revistas, en el s. XVIII, que se dirige a una esfera pública pretendidamente homogénea. Por otro, al crítico romántico

\footnotetext{
${ }^{11}$ Este compromiso con su clase se ve atenuado, o por lo menos en una estabilidad crítica, debido a sus ideales románticos y su distancia de dandy, que Gross ve como un elemento positivo, dado que le agrega sabor y lo ayuda a mantener la independencia de criterio (Ver Gross 59 y 67).

${ }^{12}$ Una élite de caballeros informada por cualidades espirituales distintivas, aunque difíciles de precisar: "urbanity, informed judgement, delicacy of perception, sweetness and light. They were intended, in other words, to constitute both a spiritual and a cultural aristocracy, to combine the roles of Isaiah's righteous remnant and Stendhal's Happy Few" (Gross 70).
} 
que, ante su visible resquebrajamiento, decide no mezclar su discurso en las lides políticas y se vuelve hacia un conocimiento trascendente a través del arte; Eagleton, como adelanté, los llama 'sabios'. La cada vez más compleja y fragmentada esfera pública dará, según sus denominaciones, un 'nuevo' actor:

El siglo XIX habría de producir una categoría que unió al sabio y al autor de críticas para revistas bajo una incómoda denominación, la de "hombre de letras". Es un término interesante aunque escurridizo, más amplio y más nebuloso que el de "escritor creativo", y no del todo sinónimo de erudito, crítico o periodista. T. W. Heyck ha argumentado que es el término más aproximado que encontramos en la Inglaterra del siglo XIX para una categoría que significativamente está ausente, la de "intelectual", y que no se extendería en su sentido moderno hasta fines de la década de 1870. (51)

Como el periodista del s. XVIII, el hombre de letras es más el portador de un saber ideológico general que el exponente de una disciplina especializada; se trata de quien, no limitado por un conocimiento específico, puede abarcar los campos del saber con una visión panorámica. La autoridad que se le confiere lo emparenta con el sabio, pero mientras en aquél se basaba en su distancia trascendental, en éste se trata de una imbricación fruto de la necesaria amplitud que su trabajo le requiere. Si los juicios del sabio son autoritarios y distantes, el hombre de letras se propone aún cohesionar mediante un discurso racional común la desgastada esfera pública. Por esta, y otras razones, el hombre de letras se convierte en un centro de tensiones ideológicas y técnicas donde ya pueden vislumbrarse los diversos caminos de la crítica contemporánea. El dilema que se le presenta es si emitir sus juicios en nombre del público general o de las minorías letradas; si ejercer la autoridad del sabio o buscar el lenguaje del consenso de los periodistas del s. XVIII (54-55). En este momento el hombre de letras se encuentra a un tiempo dentro y fuera de la esfera pública, podríamos decir que intenta cohesionarla desde fuera; se presenta así también una tensión del lenguaje específico de la crítica, dado que trata de dirigirse en un lenguaje común a un público que ya no siente como igual. Entre la cultura que representa y las fuerzas de ampliación del mercado, el hombre de letras intenta una sutura imposible: "El hombre de letras ha de ser a un tiempo fuente de autoridad sapiencial y sagaz divulgador, miembro de una élite culta espiritual pero vendedor intelectual verosímil” (58).

Un saber disciplinar cada vez más específico, la creciente división del trabajo intelectual, la aparición de revistas especializadas, producen en el último cuarto del s. XIX una fragmentación del conocimiento que pone en jaque la supervivencia de la crítica como se conocía hasta entonces. Sin embargo, sobrevive en Inglaterra un tipo de 
discurso amateur de relevancia crítica que se publica en revistas y periódicos de amplia circulación; se mantiene así lo que Gross llama "a tradition of lucid haute vulgarization" (78).

Según Walter Bagehot (1826-1877), debe hablarse al público de manera que entienda; esto es imposible bajo la forma de la ciencia, con su rigor, su método y su especificidad; esta instrucción, dice, puede lograrse mediante "el ensayo crítico y la crítica ensayística" (Eagleton 56). Bagehot es un claro exponente de cierta crítica informal, ligera pero culta, fragmentaria, con alusiones diseminadas aquí y allá que revelan familiaridad con una vasta literatura, con muchos aforismos y nada de teoría; responde para él a las características de la vida y la literatura moderna. Por el contrario, los escritos de Leslie Stephen (1832-1904), padre de Virginia Woolf, se muestran más nostálgicos; anhelaba la cultura pretendidamente más homogénea del siglo anterior, un grupo compacto de gente educada donde Johnson podía ser una autoridad indiscutida. La época en que toda una literatura podía ser gobernada por los estándares de una élite había quedado atrás. A pesar de todo, trató de educar a su amplio público mediante ensayos fundamentados, didácticos $\mathrm{y}$ en lenguaje accesible, preferentemente biográficos. Admiró sin reservas a Sainte-Beuve.

Los críticos de la primera época victoriana usaron, en su mayoría, un tono pedagógico, moralista, de tintes políticos y religiosos. En la década de 1870 empieza a notarse un cambio de atmósfera que pondrá en primer plano a otro actor: los bookmen, los amantes de los libros; si bien ya existían como tipos del campo literario inglés, dejan ahora de ser periféricos y se convierten - por largo tiempo, hasta la Primera Guerra Mundial- en quienes forman la opinión de gran parte del público lector cultivado ${ }^{13}$ (145). El discurso perentorio del sabio se relaja en las digresiones de la causerie, el énfasis doctrinario se torna amena apreciación. El oxfordiano Andrew Lang (18441912) fue uno de los personajes influyentes del período: escritor polifacético, entre sus trabajos se cuentan biografías, historia, estudios sobre el mito y los rituales, compilaciones varias -las más conocidas sobre cuentos de hadas-, poemas y sus recordadas traducciones de Homero. Si ninguna de sus ficciones es memorable, sus amplios saberes y su estilo le otorgaron un sitial preponderante. Sobre cualquier cosa

\footnotetext{
${ }^{13}$ Período de lo que Mencken llamó ‘beautiful letters'. El bookman puede considerarse, según Gross, primo hermano del esteta, con su apreciación del arte por el arte; también aprende las lecciones de Walter Pater, pero saca conclusiones menos dramáticas (145).
} 
que escribiera, su prosa denota que quien escribe vive en un mundo delineado por los libros.

Si Andrew Lang es un ejemplar del catedrático devenido periodista, su colega George Saintsbury (1845-1933) funciona como exitosa contraparte: un periodista que en su madurez se convirtió en el más exitoso de los profesores, una institución en sí mismo. Para muchas generaciones de ingleses su nombre fue sinónimo de la asignatura Literatura Inglesa o Inglés (lo cual, según veremos más adelante, parece una paradoja); sus dos libros mayores, A Short History of English Literature (1898) y A History of Criticism (3 vols., 1900-1904), aún se reeditan. Saintsbury, recién graduado, fracasó en sus primeras oposiciones, por lo que se instaló seis años en Guernsey, desde donde comienza sus colaboraciones como connoisseur de la literatura francesa; a su vuelta a Londres, en 1876, se desempeña con éxito como un reviewer muy versátil. En 1895 obtiene un puesto en la Universidad de Edimburgo y renuncia a la prensa periódica. Gozó en vida, por su carisma, de gran fama como profesor, aunque sus métodos hoy parezcan tan extraños a la academia: según Gross su filosofía fundamental podría resumirse simplemente así: "first read all the books, and then recommend whatever you have enjoyed as forthrightly as possible" (157). Juzgaba los libros, y recomendaba hacerlo, como Borges, de un modo puramente hedonista; durante su carrera libró una ruidosa batalla contra los teóricos y los constructores de sistemas: "The Rule in Criticism brings Hell and Death; the readiness to accept the illimitable idiosyncracy of the work for what it is in itself worth (as the advertisements say) to YOU, brings Heaven and Life" (159). Creía que su trabajo se circunscribía a una labor simplemente estética, una cuestión de literatura; creía que ésta carece de cualquier implicancia práctica y que no es un vehículo idóneo para el cambio social. Edmund Wilson, un gran admirador suyo, llama la atención sobre su independencia crítica, la capacidad que tuvo de reconocer los méritos literarios de autores cuyos puntos de vista aborrecía ${ }^{14}$. Su basto trabajo trasluce una creencia inquebrantable en la literatura como una república en la que cualquiera, con la debida frecuentación, puede ejercer sus derechos (163).

Como puede verse en el caso de Saintsbury -está en la universidad pero no está especializado-, en la crítica comienzan a acentuarse tensiones en cuanto a su función

\footnotetext{
${ }^{14}$ Los estetas no tienen por qué ser conservadores, en todo caso son indiferentes, o liberales. Pero generalmente, por lo menos a fines del s. XIX, fueron, según Gross, de derechas. "It may be that those whose first aim is to 'appreciate' the world are the natural enemies of those whose first aim is to change $i t^{\prime \prime}(168)$.
} 
social se refiere. El gacetero cumplía su labor tratando de cohesionar una naciente esfera pública en base a un discurso ameno, imbuido de una racionalidad didáctica; sus funciones culturales y políticas estaban a la vista. El sabio, desdeñando contaminarse en la arena de la lucha pública, eleva su discurso a los ideales del conocimiento y la poesía trascendente. El hombre de letras, que se distancia de uno por sus facilidades y del otro por su enclaustramiento, queda a merced de los cambios en el campo cultural de la Inglaterra victoriana: ajeno a las luchas políticas, como árbitro del gusto público sus funciones mediadoras se vuelven problemáticas por la accesibilidad de la literatura popular y, sobre todo, por la tiranía del mercado en las decisiones del consumo cultural. La tensión puede sostenerse en un balance precario o decidirse por dos caminos que en fin no le prestan solución:

El hombre de letras victoriano es un problema que nunca ha dejado de acosar a la institución crítica inglesa, y que de hecho sigue sin resolverse hoy en día: o la crítica se esfuerza por justificarse a sí misma ante la opinión pública manteniendo una responsabilidad humanística general hacia la cultura como un todo, cuyo amateurismo cada vez será más entorpecedor a medida que se desarrolle la sociedad burguesa; o se convierte en una especie de habilidad tecnológica, cimentando así su legitimidad profesional a costa de renunciar a una mayor relevancia social. (Eagleton 64)

No dispuesta a perder su integridad al entablar lucha con los periódicos y las fuerzas del mercado, la crítica se aleja del público refugiándose en las universidades; gana en superioridad lo que pierde en potencia, gana una estructura profesional e institucional a la vez que queda marginada del ámbito público. Entre la universidad y el mercado, el hombre de letras tradicional es ignorado por la cátedra -dada su falta de especialización- tanto como por la masa de lectores.

Las primeras cátedras de Inglés en Oxford (1885) y Cambridge (1911) datan de finales del s. XIX y principios del XX; hasta esa época, como señala Gross, la noción de critique universitaire apenas existía en Inglaterra (182). Como instituciones tradicionales, estas universidades se opusieron fuertemente a la introducción de Inglés; todo en ella les parecía sospechoso: "it was modern, it was enticing, it was bound to be the softest of soft opinions. Most of all, it was unnecessary" (188). Mientras las universidades se ocupaban de los textos clásicos con una visión filológica, las ediciones, y las biografías de los autores patrios estuvieron a cargo de dedicados hombres de letras. Falta de tradición, fue un acuciante problema establecer la currícula de esta materia, que por momentos se desviaba hacia consideraciones secundarias. La materia crece, pero no 
hay certezas sobre la dirección que debe tomar. Leslie Stephen, en su ensayo "The Study of English Literature", sugiere que deberían conjugarse de forma armoniosa la crítica, la erudición y el placer; propone nuevas formas de relacionar la historia social e intelectual con un enfoque interdisciplinario; pero sus ideas no son tomadas en cuenta. Stephen, que no tenía una buena opinión de la academia, admiró sin embargo a Sir Walter Raleigh (1861-1922), profesor de Inglés en Oxford a partir de 1904; era el tipo de crítico que aporta sutileza y delicadeza sin perder el sentido común johnsoniano; representaba su ideal de eclecticismo. Además, según Stephen, tenía un estilo admirable (197). Lo que para Stephen son virtudes, son defectos para Mrs. Q. D. Leavis, para quien Raleigh representa el peor tipo de crítico, aquel que no pudo ser escritor y entonces soporta con rencor la literatura; un claro ejemplo del académico antiacadémico, alguien a quien, según Gross, no se sabe por qué razones, los departamentos de Inglés suelen atraer (198). Se trata de un caso similar al de Sir Arthur Quiller-Couch (1863-1944), profesor de Cambridge a partir de 1912, cuyas visiones de la vida y la literatura eran todavía las de un gentleman. Ambos pueden ser tomados como figuras de transición dentro de la academia. Inglés había abandonado sus antiguos orígenes pero aún no estaba completamente profesionalizado. Para la década de 1920 la moderna crítica académica ya los había suplantado.

El movimiento crítico asociado a la revista Scrutiny (1932-1953) con Frank Raymond Leavis (1895-1978) a la cabeza, marca la última resistencia de la crítica universitaria inglesa por seguir sosteniendo su relevancia social, a la vez que acentúa las tensiones. Si, por un lado, los valores literarios no son 'universales' que todos pueden compartir, por otro lado el discurso crítico sí debe plantearse el problema de su relevancia:

Y la habilidad de ser relevante, en lo tocante a las obras de arte literario, no es una mera cuestión de buen juicio; implica una comprensión tal de los recursos del lenguaje, de la naturaleza de las convenciones y de las posibilidades de organización que sólo puede proceder de una experiencia literaria intensiva acompañada del hábito de análisis. (Leavis, citado por Eagleton 80)

En la ambivalencia de sus postulados Leavis sostiene que la literatura no está esencialmente separada de la vida y de los demás discursos sociales, pero la crítica ya no se plantea bajo la única racionalidad del 'buen juicio'; requiere de métodos, prácticas y experiencias que le están negadas al lector corriente. Propone entonces para la crítica un 'tercer dominio' que se aleje tanto del positivismo científico como del mero subjetivismo apreciativo; al hacerlo, lleva a la crítica a un camino sin salida: sus juicios 
deben ser públicos, tratando la literatura como materia de relevancia social, pero el lenguaje y las técnicas específicas en que los realizan dejan fuera de la comunicación a la parte no profesional del circuito; se trata de un discurso desde-fuera, obligado a volverse sobre sí mismo. Considerando que el público general está de alguna manera pervertido en sus gustos a causa de los intereses mercantiles y que sólo una minoría especializada posee la experiencia y las herramientas que posibilitan un juicio valedero, la crítica ya no puede quedar legitimada en la esfera pública literaria. La crítica, que había perdido relevancia social con la desintegración de la esfera pública clásica y el avance del poderío mercantil, se refugia en las universidades; en su intento de afianzarse en la profesionalización como materia de saber específico, refina sus instrumentos cognitivos de análisis a la vez que crea teorías que los sustenten, pero en este mismo movimiento defensivo se aleja definitivamente de su antiguo público y de las normas comunes que le permitían la comunicación; y así, se vuelve cada vez más un discurso obligado a autolegitimarse.

\subsection{Cyril Connolly y los últimos hombres de letras}

A partir del panorama antecedente, podemos decir que para la época de la Segunda Guerra Mundial, la posición del hombre de letras es la de un superviviente. Fruto de un humanismo liberal, cuya creencia fundamental en el hombre occidental y sus logros culturales se van desmoronando con los desastres del s. XX, apenas resiste en las tensiones desgarradoras entre el mercado y las universidades, la generalidad y la especialización, el amateurismo y la profesionalización, el individualismo y la sociabilidad. Se trata de una figura nostálgica, antiguo representante de un espacio de racionalidad culta compartida, que se expresa en una prosa que aspira a las facilidades de la elegancia; un árbitro del gusto que, en su individualismo, cree representar los valores de una esfera pública pretendidamente homogénea; un caballero de salón, resabio de siglos pretéritos; un literato que no se confunde con el académico, anterior a los estudios profesionales sobre literatura. En cierto modo, la crítica literaria universitaria es un discurso científico, se apoya en normas y teorías que buscan excluir lo subjetivo para acercarse a la universalidad (generalización) del conocimiento; analiza la literatura desde una perspectiva y con un lenguaje propio, distinto del literario. Los críticos ensayistas (T. S. Eliot, Virginia Woolf, Lytton Strachey, W. H. Auden, Cyril Connolly, para hablar del s. XX inglés) consideran en cambio la crítica como un texto literario, flexible y subjetivo, con voluntad de estilo; y al hombre de letras y su obra 
como parte del sistema literario. La dicotomía extrema podría ser falsa, pero el conflicto de discursos existe ${ }^{15}$.

Según pude precisar, los autores que se ocupan del hombre de letras abundan sobre la imprecisión del concepto. A través de las características que fui develando, voy a definir al hombre de letras como un escritor de reconocida autoridad en el campo cultural/artístico, de intereses varios y una escritura más atenta al estilo que a la precisión conceptual; ajeno tanto a la academia como a los dictados del mercado, sus apreciaciones parten de la experiencia del objeto artístico y no especifican ningún sustento teórico. La inestabilidad de su posición histórica tanto como la inespecificidad de sus competencias son intrínsecas a la dificultad de su definición conceptual.

La genealogía precedente, y las características comunes que me permiten delinear una definición del hombre de letras, hacen que ahora pueda situar a Connolly en un momento particular, de transición, en la tradición y el campo literario.

Cyril Connolly estudió en Eton y en Oxford entre 1918 y 1925; tuvo la formación humanística más privilegiada y tradicional, asistiendo a los centros educativos donde Inglaterra formaba a sus futuros hombres prominentes; en Eton fue compañero de George Orwell -que también escribió un ensayo autobiográfico sobre la experiencia, a pedido del propio Connolly-, y en Oxford, de los novelistas Evelyn Waugh y Anthony Powell. En la escuela, una de las más antiguas de Inglaterra, fundada en 1440 por el rey Enrique VI, comenzó la ardua creación de su personaje para sobrevivir a las crueles tradiciones y la competencia exigente; en esa microsociedad conservadora y violenta, que privilegia la apostura, los deportes y el carácter, el gordo y sentimental Connolly comienza a perfilarse como un brillante e implacable satirista, erudito, inteligente, seductor. Logra así popularidad, y llega a ser miembro de las sociedades más exclusivas del colegio. Más allá de las dificultades que tuvo que sortear, esta será para Connolly su ‘época dorada', a la que, romántico y nostálgico, siempre dirigirá sus anhelos; allí formó

\footnotetext{
${ }^{15}$ Ya cité algunos ejemplos, y ahora amplío con estos otros: los ataques cruzados que Connolly en Inglaterra y Edmund Wilson desde Estados Unidos mantuvieron con la academia; Frank Kermode censuró en Connolly el amateurismo, el diletantismo de una obra como The Modern Movement (Domínguez Michael 79); Edmund Wilson calificaba a los académicos de "asesinos de todo lo viviente y real en literatura y en arte clásico, medieval y moderno" (Berlin 18).
} 
su carácter y su visión del mundo, y allí se formó lo que Connolly consideraría su cruz: ser una gran promesa. ${ }^{16}$

En 1922, en el pináculo de su éxito, Connolly finaliza sus estudios y debe abandonar Eton para entrar en la Universidad de Oxford. Como si después de semejantes logros no lo quedara sino caer, estudia muy poco; sus estudios de historia no le entusiasman. Como un decadente romántico, practica una indolencia refinada. Disfruta de comer afuera y beber con amigos, aplica su ingenio a la conversación, lee por gusto; hace lo que le place; y así pasó su tiempo en Oxford. En 1925 aprueba pobremente sus exámenes finales, decepcionando a familia y amigos; sus antecedentes hacían prever mayores logros académicos. A Connolly no pareció afectarle este aparente fracaso; los honores universitarios le parecían superfluos, y consideraba que no eran demasiado pertinentes para la carrera de escritor que había empezado a fantasear en los últimos años. No estaba demasiado preparado para ingresar al mundo laboral, el dinero se terminaba y sus padres, separados y en no muy buena posición económica, apenas accedieron a darle una modesta asignación mientras se buscaba un trabajo estable. Sus conocimientos, valores y vivencias de esta época quedarán plasmados en uno de sus libros más recordados, que justamente se titula Enemigos de la promesa (1938), escrito en su mediana edad; se trata de un programa estético, una regla para artistas, la autobiografía de una promesa trunca. Será objeto de un detallado análisis en su capítulo correspondiente.

Por fin, en junio de 1926, Connolly consigue un trabajo aparentemente hecho a su medida: el escritor Logan Pearsall Smith (1865-1946) busca a un joven erudito que le sirva como secretario, Cyril se ofrece y enseguida Logan lo toma. Las tareas son pocas y amenas: corregir las pruebas de algún artículo, buscar en los libros alguna información específica; el trabajo le dejaría mucho tiempo libre para sus propios escritos y le proporcionaría un ingreso regular. Logan Pearsall Smith es un escritor norteamericano nacionalizado inglés, hijo de una acaudalada familia; tiene una amplia casa en la ciudad y otra en la campiña; no necesita trabajar e invierte su tiempo en encarnar al perfecto gentleman inglés y en pulir día a día sus frases, epigramas y anécdotas que irán conformando pequeños libros; entre los más recordados se encuentran Trivia (1918) y

\footnotetext{
16 "Near the end of his time at Eton, Connolly was teased about his achievements by a friend who joked, 'Well, you've got a Balliol scholarship and you've got into Pop-you know, I shouldn't be at all surprised if you never did anything else the rest of your life.' [...] He began to worry that he had come too far too fast, and that reality would catch up with him and never again bring him anything to compare with his honours at Eton" (Shelden 16).
} 
More Trivia $(1922)^{17}$, así como el estudio, fruto de su intensa dedicación a la lengua inglesa, The English Language (1912); su obra restante se compone de antologías y selecciones, lecturas y ediciones de los clásicos ingleses, Shakespeare y Milton, entre otros. Logan, soltero y sin hijos, disfruta de aconsejar y proseguir la educación de Cyril, cuyo padre está lejos y en complicadas relaciones con su hijo. Como mentor de su carrera, le presenta a uno de los hombres de letras más importantes de Londres, el crítico y editor Desmond MacCarthy (1877-1952), cercano al grupo de Bloomsbury y editor literario del New Statesman. Ambos se caen bien y MacCarthy decide apoyarlo; así, le encarga algunas reseñas menores que aparecen sin firma. Contento con los resultados le pide que reseñe una nueva edición en siete volúmenes de las obras de Laurence Sterne, una tarea mayor para un joven de sólo veintitrés años. Connolly sale airoso de la prueba, y la primera reseña con su nombre aparece el 3 de septiembre de 1927. MacCarthy le ofrece entonces una columna quincenal en el New Statesman para reseñar novelas.

Trabajó en el diario hasta febrero de 1929; disfrutó de reseñar algunos buenos libros del momento - Contrapunto (1928) de Aldous Huxley, Muerte en Venecia (1912) de Thomas Mann, Hombres sin mujeres (1927) de Ernest Hemingway, Decadencia y caída (1928) de Evelyn Waugh- pero se cansó al fin de tener que leer y reseñar tantos libros de segundo orden. Connolly creyó saber cuáles eran los errores y aciertos en la factura de esos libros y se decidió a escribir los propios. Cuando abandonó el diario tenía dos novelas empezadas. Para ese entonces ya había comenzado su periplo de viajes, otra de sus grandes pasiones: estuvo en Portugal, España, el norte de África, Italia y París, donde, entre otros muchos escritores e intelectuales, conoció a la heredera norteamericana Jean Bakewell, con la que se casó en abril de 1930. El dinero de Jean le permitió viajar y dedicarse a la literatura. En 1934 terminó por fin la que sería su única novela, The Rock Pool ${ }^{18}$, que recién se publicaría en la Olympia Press de París en 1936. El libro no satisfizo ni a Connolly ni a la crítica; no estuvo a la altura de lo que se esperaba de su talento. En 1938 publicó Enemigos de la promesa, donde, entre otras cosas, da las razones de su fracaso a la hora de escribir la obra maestra que se creía podía escribir. En 1940 fundó, con Peter Watson, coeditor y mecenas, la influyente revista literaria Horizon, al frente de la cual tuvo su logro más indiscutido; la revista

\footnotetext{
${ }^{17}$ Existe traducción castellana de estos libros, agrupados en el volumen Todas las trivialidades. Traducción de Héctor Blanco. Prólogo de Emilio Quintana. Oviedo: Trabe, 2010.

${ }^{18}$ Hay traducción castellana de esta novela, con el título En el fondo del estanque. Traducción de Jordi Fibla. Madrid: Versal, 1990.
} 
salió hasta 1950. Mientras tanto Connolly escribe, en los años de la guerra, su otro libro mayor, La tumba inquieta, publicado en 1945; se trata de una serie de reflexiones literarias y vitales, citas, diarios, etc., donde Connolly plasma sus pasiones, anhelos y saberes y, como trasfondo, el fracaso de su matrimonio con Jean Bakewell. Ese mismo año publica la primera recopilación de sus artículos The Condemned Playground. En 1953 apareció en forma de libro Ideas and Places, una selección de sus editoriales en Horizon. De 1952 hasta su muerte en 1974 Connolly fue, junto a Raymond Mortimer, jefe de la sección de crítica literaria del influyente periódico dominical Sunday Times, donde aparecieron regularmente sus críticas; Previous Convictions (1963) y The Evening Colonnade (1973) son recopilaciones de estos trabajos. En 1965 había publicado su canon personal del movimiento modernista Cien libros clave del movimiento moderno. Se había casado dos veces más, en 1950 con Barbara Skelton, y en 1959 con Deirdre Craven, de la que tuvo dos hijos en su adultez.

La obra de Cyril Connolly ocupa una posición problemática, ambivalente en el campo literario. Ambicionó ser un novelista serio y fracasó en el intento. En vida sólo publicó The Rock Pool; comenzó algunas novelas más, ninguna de las cuales terminó (póstumamente, en 1989, se publicaría Ampara esos laureles, finalizada por Peter Levi, quien a la muerte de Connolly se casó con su mujer). Conoció la fama como hombre de letras, sobre todo gracias a sus libros ensayísticos más recordados, Enemigos de la promesa y La tumba inquieta, y a su labor como editor a cargo de la revista Horizon; un período que va de 1938 a 1950. Después de ese período, no volvió a escribir un libro unitario; se tratan todos de recopilaciones de editoriales y artículos. Hasta su muerte escribió artículos diversos sobre viajes, gastronomía, bibliofilia, y, sobre todo, crítica de libros, que gozaron de fama e influencia, de arbitrio, sobre un público lector que Connolly no respetaba demasiado, y entre algunos escritores. La crítica académica menospreciaba su calidad de amateur, de diletante de las letras. Entre las efímeras modas del mercado y la teoría de las cátedras, el mismo Connolly se hizo eco de estas tensiones y despreció en varios escritos su trabajo, el desplazamiento, casi el no-lugar, que su figura de hombre de letras ocupaba en el campo literario contemporáneo. Cabe aclarar que su valor vuelve a discutirse en cada reedición de sus obras. 
Cuando se habla de Connolly en cuanto hombre de letras, suele citarse como figura análoga a su contemporáneo estadounidense Edmund Wilson (1895-1972). ${ }^{19}$ Éste estudió en Princeton, donde fue compañero, y, en cierta manera, conciencia literaria de Francis Scott Fitzgerald. Fue un entusiasta de la Revolución y la cultura rusa, "un crítico pragmático, individualista, que buscó en los elementos externos al fenómeno literario claves que lo iluminaran" (Major 9). Creía que Estados Unidos era un país joven, y que sus clases medias debían ser educadas en sus gustos literarios y culturales. A pesar de las varias ofertas, siempre rechazó ocupar puestos institucionales y académicos. Escribía únicamente para el público, en una prosa cuidada y accesible; desconfiaba de los credos, "escéptico siempre a todo academicismo, a toda teoría o abstracción que condicionase la lectura como si fuera una llave maestra" (11). Alejado de las nuevas interpretaciones literarias que se fueron sucediendo durante su vida, Wilson se acercó a la literatura con "el temple de los hombres de letras del siglo XVIII y XIX en Inglaterra y Francia, en primer lugar de Taine y su Histoire de la littérature anglaise, descubierta en la biblioteca paterna, aunado al magisterio moral de Emerson" (19); sus fundamentos críticos se apoyan en la crítica y la historiografía de autores como Edward Gibbon, Jules Michelet, Matthew Arnold, Sainte-Beuve y Georges Saintsbury. Según Frank Kermode su método consistía en "la identificación apasionada [con la obra] hasta desentrañar sus mecanismos para posteriormente alejarse y disponer de una distancia objetiva en el contexto de la inferencia histórica" (citado en Major 20). Entre sus obras cabe destacar Axel's Castle. A Study in the Imaginative Literature of 18701930 (1931), un libro clave sobre la revolución literaria modernista, donde Wilson está más interesado en las innovaciones que en las rupturas con respecto a la tradición; To the Finland Station: A Study in the Writing and Acting of History (1940) su estudio de crítica histórica y de las ideas; The Wound and the Bow $(1941)^{20}$, una recopilación de ensayos literarios. Además de los mencionados, toda su carrera está atravesada por la

\footnotetext{
${ }^{19}$ Múltiples son los ejemplos, y para certificar su actualidad, elijo uno de ayer (11/6/17): “"La claridad es la cortesía del filósofo", dijo alguna vez José Ortega y Gasset. Pocos de sus colegas siguieron el consejo, pero la tradición anglosajona de la crítica literaria ha observado esta regla desde tiempos de Samuel Johnson. En el siglo XX fue respetada por autores tan lúcidos como el norteamericano Edmund Wilson, crítico de la "generación perdida" (Hemingway, Dos Passos, Scott Fitzgerald) y, del otro lado del Atlántico, por su contemporáneo Cyril Connolly (1903-1974), lector sagaz de Auden, Eliot y Joyce. Lumen publicó la Obra selecta de ambos autores en sendos volúmenes, editados en 2008 y 2006, respectivamente. El sucesor de estos críticos fue el canonizador literario y polemista Harold Bloom, hoy de 87 años." GUERRERO, Pedro Pablo. "James Wood, el nuevo referente de la crítica anglosajona". Revista de libros. El Mercurio. Santiago de Chile. (http://www.economiaynegocios.cl/noticias/noticias.asp?id=368588).

${ }^{20}$ Existen ediciones en castellano de estos tres libros, con los siguientes títulos: El castillo de Axel, Hacia la estación de Finlandia y La herida y el arco.
} 
influencia del pensamiento de Freud y Marx. Edmund Wilson escribió en el auge de la esfera pública estadounidense de reciente formación, en un país joven y pujante, “cuando la prensa aún ejercía una profunda influencia, la crítica académica no había domesticado la sensibilidad y las clases instruidas compartían valores más o menos comunes" (28), así como el nostálgico Connolly escribió en la decadencia de la esfera pública inglesa.

En los años de posguerra Wilson viajó a Europa para escribir reportajes sobre la situación de Francia, Italia y el Reino Unido; en este último conoció a George Orwell, el escritor británico con el que más unido estaba en su aspecto ideológico, y a Cyril Connolly, con el que entabló una larga amistad. Connolly admiró sin reservas su libro El castillo de Axel (1931), uno de los tres únicos libros de crítica literaria que incluyó en Cien libros clave del movimiento moderno (los otros dos son Selected Essays, de T. S. Eliot , 1931, y The Art of the Novel, los prefacios de Henry James, 1934), y sólo excluye Hacia la estación de Finlandia por tratarse de un libro de crítica histórica y no literaria. En su valoración de Wilson manifiesta:

En Axel's Castle desarrolló una crítica marxista de algunos de nuestros escritores clave (Yeats, Valéry, Eliot, Proust, Joyce, Stein, Villiers y Rimbaud), y así inauguró el furioso asalto del marxismo en los treinta. Wilson, sin embargo, era demasiado perspicaz, demasiado artista para no adorar lo que quemaba: estos escritores llevaron la exploración del individuo a un punto que ya no se podía ir más lejos. (Connolly 1993: 89)

Además, en el artículo que escribe con motivo de la muerte de Joyce (1941), Connolly concuerda con la certera valoración crítica que Wilson hiciera de su obra -a la vez que se desliga de hacerla él mismo-: "No es éste el momento de hacer una valoración crítica de Joyce. Wilson, en las cuarenta páginas que le dedica en Axel's Castle (editado por Scribners), lo ha hecho de manera insuperable. Ha muerto esta semana [...]" (Connolly 2005: 708).

Por su parte, Edmund Wilson hizo una reseña muy favorable de La tumba inquieta, un libro de pensées donde el autor ha encontrado una forma propia; los ensayos breves y epigramas de que se compone son "concentrados, exactos y lúcidos"; nos dice que "este pequeño volumen -unas escasas ciento cincuenta páginas- es uno de los libros que más me interesó -en la medida en que ciertamente es uno de los mejor escritos- sobre los tiempos de guerra en Inglaterra" (Wilson 637). No considera The Condemned Playground a la altura del anterior, y hasta le critica algunos juicios literarios -que no coinciden con los suyos- pero reconoce que en asuntos literarios 
Connolly es más certero que "otros autores de más peso, quienes apuntan, en un vocabulario jergoso, a analizarlos sociológica, estética o filosóficamente"; le reconoce un gusto clásico no influenciado por las modas; un hombre que "lee, y escribe sobre lo que lee, porque encuentra en ello un pasatiempo agradable"; la literatura no como pretexto para la escritura sino un gusto que no se puede dejar de compartir (638). Ve además en Horizon una revista distinguida y en Connolly a un editor excepcional. En una valoración posterior, Wilson responde a las críticas contra Connolly diciendo:

Cualesquiera sean sus faltas -él mismo las ha descrito más brillantemente de lo que nadie fuera capaz de hacerlo-, es uno de esos irlandeses afortunados, como Goldsmith, Sterne y Wilde, nacidos con un don del estilo, una gracia y un ingenio naturales, que hacen que sus obras tengan la frescura de un jeux d'esprit, y a veces ese jeux d'esprit resulta perdurable, como los clásicos. (639)

Más allá del reconocimiento, la defensa condescendiente de Wilson realza lo que calla: Cyril Connolly y Edmund Wilson tuvieron, si no distintas opiniones políticas, sí distintas ideas sobre el rol que ésta debía desempeñar en sus escritos. El marxista Wilson, sin caer en el propagandismo, creía en la educación del público y la evolución de la historia; Connolly, atento al estilo y el ingenio, reniega algunas veces de forma paradójica de su público, y se preocupa de lo literario en sí, del arte por el arte. Donde Wilson pisa en firme y de cara al futuro, Connolly se angustia en la ambivalencia, encarna el fracaso, y, nostálgico, mira al pasado.

Cuando Edmund Wilson murió en 1972, el distinguido catedrático de Harvard Harry Levin publicó un ensayo titulado "El último hombre de letras norteamericano", según Hernán Lara Zavala, ese título, en Gran Bretaña, le cabe a sir Victor Sawdon Pritchett (1900-1997) (Lara Zavala 9) ${ }^{21}$. A diferencia de Wilson y Connolly, que estudiaron en los centros educativos más importantes de sus respectivos países, Pritchett fue autodidacta. Nació en Londres, en una familia que sufría dificultades económicas; terminó sus estudios en modestas escuelas, pero nunca fue a la universidad. Ejerció oficios diversos, antes de iniciarse como periodista en la década del veinte, lo que le permitió viajar por Irlanda, Francia y España. Colaboró con revistas menores, y en 1926 empezó a publicar su columna "Books in General" en el New Statesman, del que luego sería director editorial. Su reputación como cuentista comenzó a cimentarse a partir de la publicación del volumen The Spanish Virgin and Other Stories (1932). Colaboró en Horizon, y en otras revistas importantes como New Yorker. Escribió ensayos, libros de

\footnotetext{
${ }^{21}$ Para ahondar en las relaciones que Connolly tuvo tanto con Wilson como con Pritchett es de gran utilidad la biografía Cyril Connolly. A life, de Jeremy Lewis.
} 
viaje, cuentos, novelas, autobiografía y biografías (Balzac, Turguéniev, Chéjov). Murió en Londres en 1997, próximo a los cien años. V. S. Pritchett no es reconocido mundialmente por algún libro de ensayos famoso, como Connolly o Wilson, pero sus Complete Collected Essays (1991) ${ }^{22}$ forman un vasto y ameno panorama de la literatura universal, donde reseñó a los autores más diversos; contrario a los antes mencionados, Pritchett es reconocido ante todo como un escritor de ficción. ${ }^{23}$

Sus ensayos periodísticos están escritos en una prosa de estilo conversacional ${ }^{24}$, "familiar", que "tiende a ser aforística y sentenciosa sin caer jamás en la afectación o la solemnidad; es también breve y profunda, ágil y discreta" (10); informada por una amplia cultura de lector, viajero y escritor. Su estilo, a veces elíptico, fraguado en reseñas que pudieran parecer perecederas, está determinado por la forma de circulación que la época impuso a sus ensayos: "La diferencia entre el tradicional hombre de letras y los que hemos logrado sobrevivir es que lo que tenemos que decir debe ser plasmado en un par de columnas mientras que los victorianos -he ahí a Henry James- podían llevarse docenas de páginas de las revistas de entonces" (citado por Lara Zavala 10); una queja que el mismo Connolly repetía. Y amplía Pritchett, sobre la inestable situación del hombre de letras:

No contamos con un público cautivo. No impartimos clase. No somos académicos aunque mucho les debamos a los estudiosos. Nos ganamos el pan y la sal escribiendo para aquellas revistas que han logrado sobrevivir. Si acaso tenemos un pie en Grub Street [la calle de los gacetilleros en Londres], escribimos para que se nos lea con agrado y para captar la atención de lo que Virginia Woolf llamaba "el lector común". No imponemos normas pero enarbolamos los valores de la cultura humanística. (citado en Lara Zavala 10)

En marzo de 1984, a diez años de la muerte de Connolly, y con ocasión de la salida al mercado estadounidense de Cyril Connolly: Journal and Memoir, de David Pryce-Jones -que contiene, además de una semblanza crítico-biográfica, los diarios de Connolly-, V.S. Pritchett publicó en el New York Review of Books "Entre las ruinas", un artículo donde revisa la carrera de nuestro crítico. Refiere Pritchett que Connolly fue

\footnotetext{
${ }^{22}$ Existe en castellano una amplia selección: El viaje literario. Cincuenta ensayos. Prólogo Hernán Lara Zavala. Trad. Ramón García. México: FCE, 2011.

${ }^{23}$ La editorial argentina La Bestia Equilátera ha publicado dos colecciones de sus cuentos: Amor ciego (2011) y La mujer de Guatemala (2014).

${ }^{24}$ Sobre este tipo de prosa, típicamente inglesa, opina Borges en su particular estilo, al reseñar Private Opinion, de Alan Pryce-Jones, amigo de Connolly: "Es indudable que si bien hay muchos ingleses que conversan muy poco, hay muchísimos otros que no conversan. De ahí (tal vez) la no menos indudable excelencia del oral style o estilo conversado de los prosistas de habla inglesa. En este sentido, el libro que reseñamos es ejemplar" (Borges 1996: 221).
} 
descendiente de militares ingleses que cambiaban permanentemente de lugar, con vínculos angloirlandeses. Los viajes, por tanto, comenzaron en su temprana infancia, sumados a las largas conversaciones sobre antepasados celtas y normandos (Connolly pasó varias temporadas de su niñez en el castillo de su familia, en el sur de Irlanda). Siempre añoró los privilegios del Grand Tour continental, y, a pesar de sus escasos recursos, trató de llevarlo a cabo. Viajero y atento observador, enamorado de Francia y el Mediterráneo, tanto como de la ciudad de Londres. De la escuela de Eton salió marcado por los clásicos, y ya había leído mucho también en inglés y francés. Tenía ingenio y talento; pero Pritchett nombra dos desgracias que frenaron su pleno desarrollo -aclarando, al igual que Wilson, que el mismo Connolly dio cuenta de ellas de forma notoria-: "La búsqueda del placer, las cenas fuera, la persecución de las mujeres, los hábitos caros, hasta su gusto por conversar"; por otro lado, la difícil supervivencia del autor sin recursos propios ni mecenas, obligado a reseñar libros ajenos, desgastando su creatividad; "en el mejor de los casos se convierten, como él, en hombres de letras; en el peor, en gacetilleros de cara al público" (Pritchett 153).

Connolly fue, según Pritchett, un actor capaz de asumir variados papeles, dandy, egoísta y ciclotímico, tan encantador como maleducado, siempre formidable en su conocimiento. "Crítico sutil, viajero compulsivo y franco biógrafo de sí mismo, autor de Enemies of Promise y de The Unquiet Grave: el vocabulario era su elemento. Casaba con él el ansia, cuando menos, de escribir 'una obra maestra', y acuñó la ley para todo escritor que deseara trascender" (153).

Pritchett detecta, con leves diferencias, una situación de encrucijada parecida a la que vengo manejando. Tras el apogeo de la época victoriana, y luego de la guerra de 1914, las clases altas inglesas se ven afectadas de "pérdida de voluntad y falta de temple"; para 1930, la cultura de la alta burguesía, como saber válido y aglutinante, va quedando desplazada: "por un lado, se había convertido en un asunto de capillitas para minorías -Connolly era una figura habitual de este tipo-, por el otro, se había deslizado hacia el comercialismo" (153-154). Lo que Pritchett no menciona es el refugio universitario de esa cultura, de ese saber, ante la desintegración. Entre un discurso teórico de escasa relevancia social que se vuelve sobre sí mismo y un discurso formado por y para el mercado, la crítica del hombre de letras queda en un lugar sin salida: o se convierte en un discurso innecesario y endogámico, un asunto de "capillitas" minoritarias; o debe adaptarse, perdiendo su forma, a las exigencias de un mercado, un periodismo y un público que ya no lo contemplan ni lo entienden. "Un hipotético 
Connolly de hoy en día", nos dice Pritchett, "reclamaría que el hombre de letras 'pasó de moda' y que las ciencias, sobre todo los efectos niveladores de la tecnología, están acabando con cualquier esperanza de lograr una obra maestra. Ya no hay público para ellas" (154).

El hombre de letras y su discurso humanista fueron perdiendo lugar a medida que el siglo pasado avanzaba; el desmembramiento de la esfera pública burguesa en Inglaterra, el acceso masivo de nuevas clases sociales a la lectura y la información, la tiranía de la razón mercantil, la creciente especialización, con la consiguiente división intelectual del trabajo, fueron socavando la necesidad y legitimidad de sus antiguos saberes. Para el fin de la Segunda Guerra, el hombre de letras era una figura nostálgica, romántica, un superviviente. Wilson, Pritchett y Connolly son, cada uno a su modo, varias veces llamados "el último hombre de letras"; el longevo Pritchett sobrevivió hasta casi finales del s. XX, y, si bien encarna el tipo, prima su estatura de escritor de ficción, siendo reconocido como uno de los más importantes cuentistas ingleses; Wilson ejerció su autoridad crítica en el apogeo de un campo literario y cultural en formación, su temperamento y su afán pedagógico, tanto literario como político, le otorgaron un norte y un lugar para sortear la decadencia; Connolly, que pertenecía a una tradición más antigua, se vio como el último eslabón de una cultura humanista en franca decadencia, encarnó al hombre de letras totalmente dedicado al arte, a las bellas letras, el estilo y las maneras, en un campo cultural europeo escindido por el mercantilismo, los progresos científicos y las guerras. Lo mejor de su obra, que, a grandes rasgos, podemos ubicar en la década del cuarenta, ya es una elegía, la mitificación nostálgica de un fracaso.

\section{Coda}

Hombres y mujeres de letras en Argentina: Victoria Ocampo (que intentó visitar a Connolly); el más cercano al prototipo es José Bianco; Pezzoni y Piglia, de otra generación, podrían considerarse como figuras de paso, que ostentan ya la imbricación con el discurso teórico universitario o una doble pertenencia.

En nuestro campo literario argentino, José Bianco (1908-1986) podría ser una figura análoga al hombre de letras que intento delinear. Lector políglota y vasto, ensayista 
respetado $^{25}$, jefe de redacción de la revista Sur entre 1938 y 1961, ostentó una legitimidad cierta en materia literaria; se depositaba en él una creencia, en lo que a gustos se refiere, que lo constituía en una especie de "juez" dentro de nuestro campo literario, a la manera de los citados por Casanova en La República de las Letras, y que serán objeto de otro capítulo. Según Ricardo Piglia, para ciertos escritores en Buenos Aires, Bianco representaba a quien sabía qué es la literatura: un saber sobre las formas, ligado a una manera de leer y acercarse a la literatura; una seguridad en medio de la vacilación de la forma (Piglia 2006: 247). Un saber no ligado al estudio sino a la frecuentación, a una interrogación crítica, personal y hedónica, que Piglia identifica con las maneras de leer de un escritor. En un momento donde la crítica literaria, al especializarse dentro del campo de los estudios académicos, cumple cada vez menos con sus funciones en la esfera pública, Bianco puede verse como una de las últimas figuras de nuestro campo que cumple la función de "autoridad sapiencial y sagaz divulgador" (Eagleton 58), a través de una escritura que se sostiene entre dos aguas, las clases cultas y el público, los pares y el mercado.

Más conflictiva y última, más tensionada, se vuelve la figura de su amigo Enrique Pezzoni, profesor universitario y sucesor de Bianco en la revista, cuya escritura, más especializada, más técnica, va siendo cada vez menos accesible al público general $^{26}$.

\footnotetext{
25 "Lo primero, y acaso también lo último, que llama la atención al leer los ensayos de Bianco es la agradable persistencia en su escritura de procedimientos característicos de la crítica decimonónica a la manera de Sainte-Beuve (la forma en que la reflexión literaria se articula con el recuerdo de anécdotas) y del estilo sobrio y elegante de la mejor tradición de los ensayistas ingleses" (Giordano 2005: 104). 26 "El buen profesor no es aquel que no traiciona su sensibilidad de homme de lettres (el profesor se constituye en esa traición), sino aquel que, como Pezzoni en estas clases, encuentra un estilo de exposición en el que los conceptos y los modos argumentativos no niegan, sino que añoran la sensibilidad traicionada" (Giordano 2005: 283).
} 


\section{Cyril Connolly, ensayista}

\subsection{Orígenes del ensayo: una tradición europea}

La palabra ensayo proviene del término latino exagium, que a su vez se derivó del griego exagion, y se trata de un sustantivo que se utilizaba para referirse al acto de pesar. En francés antiguo dio lugar a essai, que significa intento, prueba, acercamiento, tentativa $^{27}$; con el mismo significado pasó al inglés essay, y al castellano ensayo ${ }^{28}$. La primera proferencia de esta palabra para designar un tipo de composición literaria se debe a Michel de Montaigne (1533-1592), que en 1580 tituló Essais a su colección de escritos, siendo no sólo la primera sino hasta hoy la más famosa y modélica recopilación del género. En inglés, el concepto está directamente tomado de esta fuente, y en fecha tan temprana como 1597 Francis Bacon (1561-1626) publica su libro Essayes. Sin embargo, como dijera el mismo Bacon, "la palabra es nueva, pero la cosa es vieja" (citado en Bioy Casares IX).

Como dije en el capítulo anterior respecto al hombre de letras, si bien históricamente no podemos hablar de ensayos anteriores a los de Montaigne, es cierto que, analizadas retrospectivamente, varias composiciones se aproximan en tono e intención al moderno uso del concepto. Agrega Bacon: "Las Epístolas de Séneca a Lucilo son ensayos, vale decir, meditaciones dispersas, aunque en forma de epístolas" (IX). También Montaigne admiró a Séneca (4 a.C-65 d.C.), pero más admiró a Plutarco (c.46-c.120), cuyas Moralia son composiciones cortas en prosa sobre tópicos de interés general. Si nos atenemos a estos primeros acercamientos, también pueden ser considerados precursores Jenofonte, Aristóteles, Cicerón, Marco Aurelio, Macrobio, Séneca, Aulo Gelio. ${ }^{29}$

\footnotetext{
27 "Essai": Epreuve, premèire expérience qu'on fait d'une chose [...], première tentative. Analyse rapide d'un corps, d'un produit.

"Essayer": Faire l'essai [...]. Tenter, faire effort pour voir si l'on pourra.

"Essayiste": Auteur d'essais. Littérateur anglais, collaborant surtout aux revues. Nouveau Petit Larousse Illustré. París: Larousse, 1954.

${ }^{28}$ En español ensayar aparece en el Cantar de Mío Cid (alrededor de 1200) con el significado de 'probar' y sólo a comienzos del siglo XVIII recoge del inglés la denotación de 'artículo', 'tratado' o 'escrito de análisis'.

${ }^{29}$ Cito aquí un párrafo del trabajo "Aulo Gelio y la literatura española del siglo XVI", de Francisco García Jurado, donde se reafirma mi idea de Aulo Gelio como precursor del ensayo, y se establece su particular relación con Montaigne: "En cualquier caso, no deja de ser una paradoja que tanto Séneca como Gelio se convirtieran en precursores de un nuevo género literario que se iba a gestar durante el mismo siglo XVI: nos referimos al ensayo. En otro lugar hemos propuesto que Montaigne leyó la miscelánea de Gelio desde una nueva categoría imprevista: la de no ser ensayo. La visión acumulativa y aparentemente desordenada de las cosas, a la espera de que alguien encontrase un supuesto orden, dejó paso a una visión más personal que entendía ese "desorden" ya no tanto como una circunstancia, sino
} 
Michel Eyquem de Montaigne nació en el castillo de Montaigne, cerca de Burdeos, en 1533. Tuvo una educación liberal y humanista; su padre se encargó de que el latín fuera su lengua primera; frecuentó e interrogó ampliamente a los clásicos, sobre todo a los latinos. Estudió leyes y, al igual que su padre, fue alcalde de Burdeos. En 1571 comienza la redacción de sus ensayos en la biblioteca de la torre de su castillo; una primera edición con los libros I y II aparece en Burdeos en 1580; en 1588 les adjunta el libro III en la edición de París. Ampliaba todavía sus ensayos cuando en 1592 murió en el castillo en que había nacido.

Si por un lado debemos reconocer que el ensayo no aparece $a b$ ovo con Montaigne, también es cierto que se trata de algo nuevo. Hasta el s. XVI, la forma estándar de la prosa era el discurso, o alocución; un texto utilitario cuyo fin es persuadir. Según la retórica clásica, a una primera etapa llamada inventio donde sucede la ocurrencia de los argumentos, sigue otra etapa llamada dispositio en que se disponen, se acomodan $\mathrm{u}$ organizan los argumentos surgidos de la inventio. Es en su ruptura con esta segunda etapa de la dispositio donde la escritura de Montaigne se torna algo nuevo, dado que negaba seguir cualquier tipo de plan preestablecido para escribir sus ensayos (Hardison 14-15); era consciente de estar haciendo sino algo totalmente novedoso, sí algo distinto de lo preceptado por la retórica clásica de un Cicerón o un Quintiliano -por algo explica tantas veces su proceder a lo largo de los Ensayos-. Al referirse a su estilo, se excusa: "si debo llamar estilo a un habla informe e irregular, a una jerigonza popular y a un procedimiento sin definición ni división ni inferencia, confuso, a la manera del que tuvieron Amafinio y Rabirio" (Montaigne 962); y así, parecen sus ensayos acercarse más a la libertad de la conversación que a la rigurosidad del tratado.

Montaigne escribe a vuelapluma sobre un tópico cualquiera que capte su interés en el momento; no existe selección, ni plan, ni sistema previo a la ocurrencia de la escritura. Se trata de poner en palabras las ideas como ellas están o aparecen en la mente, sin cuidarse de la coherencia, cohesión o progresión en el tratamiento temático; una respuesta espontánea y subjetiva suscitada por el objeto de reflexión elegido. La curiosidad, el análisis de Montaigne hace énfasis en lo singular; lo singular del objeto, y su singular experiencia del mismo. Es por esto que su escrutinio no parte de ni deriva hacia ningún tipo de teoría, dada la generalización que le sería inherente. Esta nueva

como una visión abierta del mundo, orientada sobre todo a reconstruir una literatura más cercana al dialogismo y la conversación. Este fue ya Montaigne, que leyó a Gelio directamente, pero también releyó aspectos de su miscelánea a través de la más moderna de Pedro Mejía (en la traducción francesa de Gruyet)" (Francisco García Jurado, consultado el 13/6/17: http://clasicos.hypotheses.org/536). 
escritura de Montaigne procede por negaciones (lo que ha hecho tan dificultosa la definición genérica del ensayo): un estilo basado en la falta de estilo, un método ametódico, una verdad que no es generalizable.

Montaigne afirma en el prólogo a los Ensayos: "Así, lector, soy yo mismo la materia de mi libro" (Montaigne 5-6); sin embargo, esta escritura del yo, o sobre uno mismo, es diferente del diario o la confesión. En el diario, cada entrada está limitada a un día, y refleja el estado de la mente en ese día; en la autobiografía o confesión la perspectiva múltiple del diario se reduce, dado que se miran desde un punto de vista único los distintos hechos pasados. En el ensayo el texto se despliega en torno a un tópico, no a fechas o eventos (Good 27); el yo relata su experiencia de ese tópico. El ensayo habla del sí mismo de manera indirecta, se trata de una autobiografía indirecta, refractada en los tópicos.

Es por esto que, desde la práctica primigenia de Montaigne, el género queda caracterizado por la intrusión del yo, que impregna todo tratamiento del tema. Y si estas son sus maneras y perspectivas, su relación entonces con la verdad que el objeto expresa también es singular; se trata de una verdad de la experiencia. Si el sujeto intenta expresar sin rodeos, con sinceridad, su experiencia particular sobre el tópico, no puede negarse la veracidad del enunciado en ese contexto, porque es la verdad de una experiencia singular y no una verdad generalizable sobre el objeto ${ }^{30}$. El mismo Montaigne es consciente de la particularidad de su acercamiento, y así comienza su ensayo "Los libros": "No tengo duda alguna de que hablo con frecuencia de cosas que los maestros del oficio tratan mejor y con más verdad. Esto es meramente el ensayo de mis facultades naturales, y en absoluto de las adquiridas" (Montaigne 585); este ensayo, nos dice Graham Good, "is an essay of the unaided self without the authority of (though sometimes with reference to) traditional learning" (28). Vuelve a plantearse aquí, de distinta pero convergente manera, el tema de la autoridad, de la legitimidad de un saber o conocimiento, que vimos desarrollarse en el capítulo anterior con respecto al hombre de letras y el crítico académico. Como expresa Good:

This distinction between authoritative literary judgement and personal literary experience could be seen as a parting of the ways between official academic criticism and informal essayistic criticism, a separation which stills exists. Montaigne did not aim, like F. R. Leavis, to create a revolution of established taste, but rather to inaugurate a new way of writing about literature -or, rather, books. [...]

\footnotetext{
${ }^{30}$ No hay que olvidar que el ensayo que cierra el libro de Montaigne, y que tal vez sea el más importante que escribió, se titula "La experiencia".
} 
The idea of writing about reading as a personal experience was clearly a new and perhaps a questionable one. (Good 35-36)

Montaigne escribe sus lecturas, sus reacciones, a la manera de un diálogo afable con los textos. Anota sus impresiones, y las persigue, de una manera más descriptiva que preceptiva; son refracciones de un sujeto lector, pensante, más que contribuciones al saber sobre la materia en cuestión: "Esto son mis fantasías, y con ellas no intento dar a conocer las cosas, sino a mí mismo" (Montaigne 585). Montaigne contrasta la experiencia con la razón como forma de satisfacer el deseo de conocimiento. La razón agrupa los fenómenos por su semejanza, y de ello deduce leyes generales; mientras que la experiencia siempre es de la variedad y diversidad del fenómeno, en su ocurrencia singular. Y, a diferencia del abstracto cogito cartesiano, la experiencia considera al sujeto cognoscente en su integridad, introduce el cuerpo y las circunstancias como participantes del acto mismo de saber ${ }^{31}$. Un saber que por eso es también del momento (Montaigne no teme contradecirse, y lo advierte a sus lectores).

La labor genitora de Montaigne tuvo rápida repercusión en Inglaterra, y menos de dos décadas después (1597) Francis Bacon publica allí la primera edición de sus Essayes $^{32}$. Las diferencias y similitudes entre sus producciones van definiendo las especificidades del género a la vez que ponen en evidencia la adaptabilidad y libertad formal que desde sus inicios lo van a caracterizar. El estilo de Bacon es conciso y ordenado; retóricamente, sus ensayos tienden a ser más conservadores, más apegados a la tradición clásica, realizando divisiones y definiciones para el tratamiento más claro del tópico. Sus ensayos tienden menos a la referencia personal que los de Montaigne; mientras que éste hizo de estos escritos su obra única, donde trazaba su autorretrato, y se buscaba a través de ideas y descripciones, aquél los consideraba un proyecto menor entre sus demás escritos, consejos fiables para el hombre ocupado (Good 45). Los ensayos de Bacon tienden hacia el orden y la claridad conceptual no por atenerse a una forma clásica, sino porque considera que así son más efectivos; la utilidad práctica de sus escritos, de sus consejos, son una cualidad característica que los ensayos de Montaigne, exploratorios, espontáneos, no se proponen -se diría que son escritos que no se proponen hacer nada, irresponsables (Hardison 15)-.

\footnotetext{
31 "Life is lived physically and individually: this is the justification for Montaigne's long description of his own bodily constitution and habits" (Good 40).

${ }^{32}$ La primera traducción al inglés de los Ensayos, de Montaigne, a cargo de John Florio (1553-1625), es apenas posterior, publicada en 1603.
} 
Ambos parecen tener distintas filosofías del yo y del compromiso de sus escritos. La concepción de la persona en Bacon tiene más vinculación social, es más relacional en cuanto se ocupa de la inserción del individuo en la estructura social; sus ensayos pretenden ser útiles para que esta relación sea armónica y provechosa; por tanto, se proponen ayudar a la reforma y autosuperación del hombre y los distintos asuntos que le competen. Por el contrario, la filosofía de Montaigne es la aceptación, la aceptación del mundo y de sí mismo; se busca en la experiencia de la escritura y va describiendo esas tentativas, sus atisbos de lo que el hombre y el mundo son; no como Bacon, cuyo fin es describir lo que el hombre debe ser.

Sin embargo, estas ideas sobre la reforma de la conducta en el hombre, contenidas en los ensayos de Bacon, no se organizan en un tratado general, sino que se agrupan en torno a un tópico de reflexión. Su verdad, otra vez, se remite, más allá de las filosofías o ideas generales subyacentes, a la experiencia del ensayista. Pero la forma de expresar y transmitir esta experiencia difiere de manera considerable en los dos autores. Sigo a Graham Good (45) en su afirmación de que los ensayos de Bacon muestran resultados, se trata de hallazgos, de los "frutos" de la experiencia, expresados en proverbios sentenciosos, con la apariencia de lo inobjetable ${ }^{33}$; en cambio, en la escritura de Montaigne asistimos al presente de la búsqueda, al proceso en sí de la indagación en el objeto. Así, por tanto, en ambos autores el ensayo se despliega como una escritura en torno a un tópico que está basada en la observación y la experiencia personal; más didácticos y orientados a la reforma de la conducta social en Bacon, más introspectivos y dirigidos al conocimiento de sí en tanto naturaleza humana en Montaigne; en ambos se expresa la verdad de una búsqueda o un encuentro personal que no está amparada por una teoría o doctrina que exprese una verdad siempre generalizable. Son estas características comunes las que marcan el nacimiento del ensayo, y delimitan los parámetros, aunque lábiles, que el género seguirá hasta nuestros días.

Diversos críticos aseveran que el Dr. Samuel Johnson (1709-1784) y William Hazlitt (1778-1830) son los hombres de letras y ensayistas más importantes de la historia inglesa ${ }^{34}$. El Dr. Johnson es considerado ejemplar en varias de las disciplinas

\footnotetext{
33 “Quizá la falta de transiciones en la redacción es el mayor defecto de los ensayos de Bacon: diríase que el texto es una sucesión de frases y no un discurso. Dentro de los límites de cada frase, la expresión es justa y, muchas veces, memorable y perfecta; [...]. El tono de conversación o de confidencia, tan oportuno en esta clase de escritos, casi nunca se logra" (Bioy Casares X).

${ }^{34}$ Según Harold Bloom: "El doctor Samuel Johnson es, a juicio de muchos (incluido yo mismo), el mayor crítico de la variopinta historia de la cultura literaria occidental. En la tradición angloamericana, el único rival que le iguala parece ser William Hazlitt, que tiene algo de la energía el intelecto y el conocimiento
} 
relacionadas con las letras: filología (su famoso Diccionario de la lengua inglesa), edición (su edición de Shakespeare, cuyo prefacio es famosamente citado), biografía y crítica (en Vida de los poetas ingleses); además, dirigió distintas revistas, que escribía prácticamente en su totalidad, y es objeto de la biografía más importante en cualquier lengua, Vida de Samuel Johnson (1791), escrita por su amigo el escocés James Boswell (1740-1795). Entre los que escribió para distintas revistas, tienen la mayor importancia sus ensayos morales ${ }^{35}$ y literarios. El cambio principal que se dio en el ensayo a principios del s. XVIII tiene que ver con su inclusión en las publicaciones periódicas ${ }^{36}$; la publicación frecuente y la lectura inmediata crean por sí mismas una sensación de espontaneidad y de respuesta pública que envuelven al ensayista en una especie de diálogo colectivo ${ }^{37}$. En la época de Montaigne la espontaneidad del ensayo tenía que ver con seguir el curso del pensamiento, atraparlo en su ocurrencia introspectiva; el 'diálogo' privilegiado era el del ensayista consigo mismo; el público se presentaba algo más lejano, el receptor difuso de un futuro libro. La lectura (diálogo) de los clásicos y el retiro reflexivo del ensayista que intenta conocerse a través de la escritura y los tópicos elegidos, son bastante distintos del saber socializado, inmediato, práctico, que a través de las revistas intenta incidir en la esfera pública. En este sentido, los ensayos johnsonianos se encuentran más cercanos en sus propósitos a los de su compatriota Bacon; intenta proveer una crítica moral de conductas particulares en una sociedad civil (Good 61), dado que para Johnson la conducta individual sólo adquiere su sentido final en la sociedad; y su idea de ese mundo y de esa sociedad es netamente cristiana. Johnson tiene una parecida opinión a Montaigne sobre la naturaleza humana, pero mientras éste la acepta sin más, aquél trata de enmendar los errores de una naturaleza caída. Estos errores, sin embargo, no pueden enderezarse únicamente por la aplicación de leyes universales, su solución no es siempre predecible; es por esto que sus ensayos son exploratorios y no simplemente dogmáticos; como dice Good: "For Johnson, experience precedes law, and not vice versa" (65) y "In literature as in life, authority and tradition are corrected by observation, and that observation is in turn subject to correction" (69).

de Johnson, pero carece del amplio abanico de cualidades humanas que tiene Johnson y, simplemente, no es tan sabio" (Bloom 2010: 85).

${ }^{35}$ Según Good (55) este subgénero no tuvo la supervivencia de los demás en la era postfreudiana, al ser absorbido en parte por la psicología.

${ }^{36}$ Ya mencioné en el capítulo anterior como las distintas extensiones que estas fueron permitiendo, también condicionan la fama y forma del ensayo periódico.

${ }^{37}$ Vimos en el capítulo anterior la responsabilidad/ participación en la esfera pública que ejercieron Addison y Steele desde The Spectator, por ejemplo. 
Como crítico o ensayista literario, el Dr. Johnson fue también un crítico de la experiencia, que “demuestra que el único método es el yo”, y, más allá de su ideología cristiana, no funda sus juicios estéticos en premisas religiosas (Bloom 2004: 197) (puede esto comprobarse en su juicio sobre poetas cuyas ideas no compartía, como en el caso de Milton). Más allá de lo antedicho, y en su calidad de literato más que de moralista, Johnson creía en el talento individual, la originalidad, tanto para la poesía como para la crítica, y antepuso el sentido común del naturalismo británico a las poéticas neoclásicas del momento, lo que le permitió ser uno de los primeros en apreciar críticamente la obra de Shakespeare.

Al igual que Johnson, Hazlitt hizo aportes basales para lo que luego sería el estudio de la literatura inglesa. Como apunté en el capítulo anterior, por esos momentos en las universidades sólo se estudiaba literatura clásica; para la vernácula, y más aún para la moderna, no se creían necesarios estudios especiales ni acompañamiento de ningún tipo. Johnson y Hazlitt se acercaron a esta 'nueva' materia no con el simple gusto y amateurismo de los caballeros educados, como pudo ser el caso de Montaigne, sino como quien, además, vive de ese conocimiento y frecuentación; sin ser lo que hoy podríamos calificar como especialistas en la disciplina, fueron hombres de letras con un vasto conocimiento de esta literatura, lo que le confería autoridad a sus juicios. Hazlitt daba lecturas sobre escritores y literatura inglesa, eran abiertas y estaban dirigidas al público general; el contenido y el tono de estas lecturas fueron formas preliminares de algunos de sus ensayos ${ }^{38}$. Así como los ensayos morales de Johnson están basados en un declarado cristianismo, Hazlitt escribió muchos ensayos de corte político donde es patente su espíritu libertario ${ }^{39}$; sin embargo, al igual que aquél, intentó cumplir con independencia y de modo idiosincrático su tarea de crítico literario.

Hazlitt reconocía en Montaigne el fundador de una nueva manera de escribir, y fue mucho más fiel a sus enseñanzas que sus antecesores; juzgaba esencial el punto de vista independiente del ensayista, no comprometido con intereses políticos o religiosos; para él el ensayo debía ser personal en la visión e informal en el tono, y no basado en ninguna ortodoxia política ni estética. Me permito introducir un par de precisas reflexiones del mismo Hazlitt sobre su práctica:

\footnotetext{
38 "Even when its subject matter [Modern English Literature] was finally drawn into the official university structure as a "discipline", it continued to occasion some of the most attractive, informal, and essayistic criticism in the hands of practitioners like Lionel Trilling or Frank Kermode (Emerson essays are, of course, nearly all revised versions of "addresses" made to general audiences)" (Good 71).

${ }^{39}$ Como dije en el capítulo anterior esto responde a las tensiones de la esfera pública, donde el periodismo político era un actor social muy importante.
} 
Applying the talents and resources of the mind to all that mixed mass of human affairs, which, though not included under the head of any regular art, science or profession, falls under the head of the writer, and "comes home to the business and bosoms of men".

It is in morals and manners what the experimental is in natural philosophy, as opposed to the dogmatical method. (citado en Good 73)

Los temas de reflexión son variados, pero el elemento catalizador es siempre la experiencia individual, expresada no en forma abstracta sino mediante su relación con el objeto, sea éste la sociedad, la naturaleza, el arte o la literatura. En un tono distendido y digresivo se suceden la memoria y el análisis, la descripción y la reflexión, lo que le da a sus ensayos una apariencia improvisada y dramática -en contraste con los de Johnson, más sosegados, más estructurados, más al estilo de Bacon en ese sentido-. Si bien Hazlitt ha contribuido a instalar la figura del ensayista como caminante y lector solitario, muchas veces pierde la calma del espectador, del que observa a cierta distancia; no rehúye la polémica, a veces su tono se vuelve impetuoso, y parece más bien alguien dispuesto a entrar en batalla. Su método habitual para el tratamiento del tema es la oposición, la dialéctica; se crean antítesis que pretenden iluminar los términos, y esto puede verse en el tópico doble que ya se presenta en los títulos de algunos de sus ensayos: "On Thought and Action", "On Vulgarity and Affectation", "On the Picturesque and the Ideal", etc. Otra de sus formas preferidas es el retrato: de personajes famosos, literatos o de su gente cercana. Por último, cabría destacar otra característica sobresaliente: Hazlitt configura muchas veces en sus ensayos un tipo literario, el del "ensayista"; se lo describe, se lo recrea, se lo pone en escena en su situación de escritura o relación con el tema; esta figura es la que muchas veces da unidad, además de sustento, al tópico en cuestión.

El hombre de letras, con su discurso ajeno a las instituciones y al conocimiento formal y progresivo de las ciencias, tiene en el ensayo su vehículo de expresión privilegiado. Si en cuanto género no le es privativo, sí le es esencial: el hombre de letras se constituye a partir de su escritura ensayística; en cuanto género proteico le permite configurar sus variadas experiencias sobre cualquiera que sea el tópico de su interés mediante los recursos más variados: análisis, descripción, reflexión, comparación, narración, etc. Todos los hombres de letras caracterizados anteriormente, desde Addison y Steele, pasando por Sainte-Beuve, hasta Lang y Saintsbury, son reconocidos en el campo de las letras por sus ensayos y es en cuanto ensayistas que construyen su figura de hombre de letras, lo que determina al fin su lugar en ese mismo campo. Johnson y 
Hazlitt son ensayistas modelos de la tradición inglesa -aunque, dentro de la amplitud del género, sus énfasis tengan objetos diferentes, que no opuestos- $\mathrm{y}$, como tales, sientan algunas bases de lo que será el ensayismo literario o crítica literaria a la manera británica. En total acuerdo con las características mencionadas en este análisis están las palabras de Harold Bloom (con su particular vehemencia) que me permito citar como síntesis:

Johnson nos enseña que la autoridad de la crítica como género literario depende de la sabiduría del crítico como ser humano y no de la corrección, o incorrección de alguna teoría o praxis. Hazlitt observó que las artes, incluida la literatura, no son progresivas, y esto incluye la crítica como rama del arte literario. [...] Johnson y Hazlitt, Ruskin y Pater, Oscar Wilde y Kenneth Burke, todos ellos representan estilos diferentes, pero relacionados entre sí, que nos enseñan cómo la crítica más memorable es una crítica de la experiencia, que no hay ningún método excepto uno mismo y, más profundamente, que la "objetividad" se acaba por convertir en algo fácil, vulgar y, por lo tanto, desagradable. La verdadera subjetividad crítica, o la personalidad crítica, pocas veces consiste en abandonarse a sí mismo, pero es difícil de lograr y depende del aprendizaje, del intelecto y del misterio de la vitalidad individual. La 'objetividad' resulta ser al final un destilado de las opiniones de otros, ya vayan estas disfrazadas de filosofía, de ciencia o de la convención social de alguna academia. (Bloom 2010: 86-87)

La tradición inglesa del ensayo, sólida y heterogénea, que vimos iniciarse en Francis Bacon, se consolidó en la escritura de hombres de letras como Addison y Steele, Coleridge y Carlyle, Samuel Johnson y William Hazlitt; en la segunda mitad del s. XIX se encuentra en su apogeo en la producción de autores como Walter Pater, John Ruskin u Oscar Wilde. Estos hombres de letras expresan en sus ensayos un clima de época (Zeitgeist), sus opiniones culturales y estéticas, a la vez que, como figuras modélicas de autor, se convierten y se recrean como árbitros del gusto en su campo específico. Ya en el s. XX se impone la figura canónica de T. S. Eliot, al que le suceden, una generación posteriores, figuras de la talla de W. H. Auden, George Orwell y Cyril Connolly. En el siglo pasado, a medida que el avance de la ciencia positiva va ganando para sí cada vez más objetos de estudio específicos, el ensayo, sin perder su irresponsabilidad y su carácter omnívoro, se concentra más en ciertos tópicos como las artes, los viajes y los recuerdos, tópicos más fáciles de asumir dentro del registro personal y estético del género. El ensayo sobre literatura, fue, desde los inicios del género, uno de los más elegidos, y durante mucho tiempo considerado la forma más idónea para la crítica literaria, o para escribir sobre libros; si bien aún sobrevive, a partir del ingreso de la literatura vernácula a las universidades -con el consiguiente estatuto científico del 
estudio de la literatura-, su legitimidad como saber se encuentra siempre en situación problemática, y su producción y circulación no ha vuelto a ser la misma.

\subsection{Las problemáticas del ensayo como género proteico}

La pregunta sobre lo que el ensayo es tiene la suficiente generalidad como para no encontrar respuesta precisa, sin embargo, resulta aquí útil para proseguir mi acercamiento. Voy a tomar en este caso dos definiciones; la primera, de Edmund Gosse, citada por Bioy Casares: "El ensayo es un escrito de moderada extensión, generalmente en prosa, que de un modo subjetivo y fácil trata de un asunto cualquiera" (Bioy Casares IX); la otra, que pertenece a Alberto Giordano, se refiere de manera específica al ensayo "literario", pero el adjetivo no refiere a la temática del ensayo, sino, como en otra parte aclara Giordano: “Tal como la entiendo, la 'literariedad' de un ensayo depende no tanto de su tema como de que en él se realice la puesta en acto de una legalidad propia de la literatura, de un modo de 'conocer' literario" (2005: 225). Veamos ahora la definición:

es, como se sabe, el género de las reflexiones ocasionales y fragmentarias en las que una subjetividad individualizada por sus gustos y sus talentos conjetura, en primera persona, las razones de lo inquietante de un texto. (2005: 262)

Estas definiciones comparten el carácter subjetivo del género y, en consonancia con éste -si lo que Gosse denomina "fácil" podemos equipararlo a las "reflexiones ocasionales y fragmentarias" de Giordano-, cierta ligereza, cierto capricho, que liberan al contenido de "la compulsión al entendimiento, de la exigencia de justificarse por consenso" (254). Porque el ser del lenguaje en este discurso no es comunicar la certeza de un conocimiento, sino establecer un diálogo con los textos y temas, y para hacerlo utiliza su mismo lenguaje, el del estilo. "El ensayo interpela a la literatura según su modo" (223), la prolonga haciéndose eco del deseo de escritura que estuvo en su génesis. Se teje con un lenguaje de la experiencia, y es aquí donde el ensayista se vuelve autobiógrafo, "alguien que escribe su vida cuando cree escribir sus lecturas" (Piglia 2005: 141). Lenguaje de estilo y lenguaje de experiencia, el ensayo produce un saber que "es esencial, pero no generalizable" (Giordano 240).

Si bien el ensayo es reconocido como un género textual, los conocimientos que se le asocian suelen ser difusos; los demás géneros han decantado, en su larga historia, hacia un cúmulo de saberes tranquilizadores sobre su estatuto en la institución literaria, e incluso, en períodos que podríamos llamar clásicos, han contado con su preceptiva; cabe 
decir que la novela y el ensayo no tienen precedentes realmente establecidos en la antigüedad clásica. La literatura moderna se practica, en gran medida, como ruptura y transformación de estos moldes aceptados, pero al inscribirse en una serie, no los puede negar como parte de su tradición. El ensayo, sin embargo, se constituye y se instituye en su misma indeterminación, como si se conformara a vuelapluma, cada vez en las decisiones mismas de la escritura (bastaría para probarlo con antologar las reflexiones del mismo Montaigne sobre su práctica, algunas de las cuales he citado); su impulso inicial tendió más bien hacia una liberación de las restricciones formales, por fuera de los géneros aceptados. La humildad de la nómina (intento, prueba, primera experiencia del hacer una cosa, rápido análisis de algo) remite a la novedad de cada práctica, como si incapacitara al ensayo de tradición a la vez que le otorga la libertad de lo primigenio. Sin embargo, cosas se han dicho y cosas sabemos sobre esta escritura, cada vez más indagada.

Del ensayo como forma. En principio, se trata de un género donde predominan las estructuras expositivo-argumentativas por sobre las descriptivo-narrativas; algunos tipos de ensayos admiten un equilibrio de estas estructuras, sin embargo, percibimos "cierta novedad" en contraste con lo históricamente dado (Mignolo 218). Nacido como una escritura del conocimiento de sí-mismo, más tarde su nombre y algunas cualidades de su forma fueron adoptados por disciplinas que se dirigen al conocimiento de los hombres y el mundo y cuyo producto pretende ser la verdad: la filosofía, la historia, y otras ciencias. En estos casos, la forma se vuelve más rigurosa. Dado que lo que se busca es un saber científico de especificidad, la lógica argumentativa se vuelve secuencial, procediendo por subordinación; efectos derivados de la necesidad del método. Sin embargo, es verdad que en estos casos deberíamos usar términos más específicos como tratado o monografía.

El ensayo de Montaigne (o a la manera de, dada la vigencia de su práctica) es una forma proteica e híbrida capaz de abordar una amplia variedad temática sin sujetarse a disciplina alguna; son ensayos "disciplinarmente descentrados" (215). Montaigne sustenta su saber en la supuesta universalidad de la condición humana, como si fuera ésta una esencia compartida; por tanto, profundizando en el conocimiento de sí, conoce al Hombre. Sólo debe bastarse con lo que es suyo, con su saber y sus cosas, con lo que ama y odia, y exponerlo a su gusto con "el ocio de lo infantil, que se inflama sin escrúpulos con lo que ya otros han hecho" (Adorno 12). Este tipo de ensayos basa su 
libertad expresiva en la negatividad: su no dependencia disciplinaria ni institucional (y en el caso de Montaigne, su no dependencia genealógica). De aquí se puede derivar otro rasgo: su independencia con respecto a un afán de totalidad. Comienza y acaba donde quiere, resalta lo que le interesa (muchas veces los detalles, lo 'secundario', lo accidental) sin preocuparse por el agotamiento de su tema, "termina cuando él mismo se siente llegado al final, y no donde no queda ya resto alguno [...]" (12). Esta autonomía interna, ametódica, le permite operar por adición y coordinación antes que por la subordinación lógica de los argumentos. Y si, por esto mismo, en su carácter subjetivo (personal, casi caprichoso a veces) el ensayo es la afirmación menos la prueba, puede entenderse la constante referencia de Montaigne a su sinceridad, sello de un pacto con el lector.

Del ensayo como verdad. El ensayo no se propone como creación ex nihilo, sino que trata sobre cosas ya dadas; su esencia no se encuentra así en el tema sino en su tratamiento, en una nueva manera de ordenar. Y el órgano principal de conocimiento es la intuición ${ }^{40}$; si bien hay estudios que han complejizado en alto grado los términos de esta facultad, me refiero con ella a la "percepción íntima e instantánea de una idea o una verdad que aparece como evidente a quien la tiene" (DRAE 2001); y aun cuando no sea instantánea, como la vida emotiva de ideas que no proceden en su mayor parte de un razonamiento riguroso. Así, en el ensayo siempre se da la aspiración a una verdad, a cierta validez del predicado; sin embargo, priman la experiencia de la forma, los procesos en sí (hay que recordar que el ensayo como tal carece de conclusiones); más precisamente, lo que alcanza es, más que la verdad, un saber sobre su objeto, "esencial (es un saber que afecta al ser de la literatura) pero no generalizable" (Giordano 2005: 240), dado que no procede de ni se establece como teoría. Mientras que el conocimiento científico se propone como acumulativo y progresivo, basado en leyes y observaciones probadas, el ensayo, que a su modo es también empírico, en tanto basado en la experiencia, la utiliza de una manera más limitada en cuanto a su validez universal. Propone un conocimiento válido pero específicamente no organizado. Por tanto, el ensayo no hace sistema, está antes o después, pero siempre fuera; y fuera de la ciencia, dado que crea sus elementos de juicio para cada caso (y la mayoría de las veces sólo

\footnotetext{
40 "La crítica literaria nada tiene de ciencia y siempre tendrá mucho de intuición personal." Alfonso Reyes, citado en de Torre, Guillermo Nuevas direcciones de la crítica literaria. Madrid: Alianza, 1970. Pág 34.
} 
tienen validez interna), afectando a lo particular. El ensayo es para Adorno la forma crítica por excelencia, imponiendo la duda sobre el derecho absoluto del método; "es radical en el 'no radicalismo', en la abstención de reducirlo todo a un principio, en la acentuación de lo parcial frente a lo total, en su carácter fragmentario" (19) ${ }^{41}$.

El ensayo existe fuera de toda organización del conocimiento (Good 4). En su espontaneidad asistemática, en su ligereza, configura un saber escéptico, que acepta la naturaleza ocasional de sus postulados. Trata sobre la verdad, pero una verdad no permanente; una verdad que vuelve a buscarse, a construirse en cada nuevo ensayo; particular, de aquí y de ahora. Dando prioridad a lo particular sobre lo general, el ensayo es más hospitalario con las excepciones que con las reglas; cultiva la diversidad donde las disciplinas buscan la unidad (6). Es por esto que se trata de una forma incómoda para las estructuras del conocimiento académico, dado que se opone a doctrinas y disciplinas en tanto conceptos pares, el primero relacionado a la enseñanza (en tanto que es desarrollado por doctores) y el segundo al aprendizaje (en tanto se dirige a estudiantes o discípulos) (5). El mismo Bacon, en De Argumentis Scientiarum, llama a su método initiative en contraste con el magisterial, que es usado para la enseñanza; uno es sugestivo mientras el otro es asertivo en toda su extensión; el magisterial requiere que lo que se dice debe ser creído, el initiative que debe ser examinado (citado por Hardison 20); es por eso que postulan un conocimiento escéptico. Las modernas disciplinas exigen un objeto de investigación delimitado, un método basado en la teoría y la práctica, y un lenguaje específico, que limita la lectura y escritura a los especialistas certificados. Por su parte, el ensayo no se basa en una experticia disciplinar, sino en la experiencia personal ${ }^{42}$.

Del ensayista. El ensayo adquiere unidad no sólo por la unidad de su objeto, sino por la omnipresencia de un punto de vista, el del ensayista, y la escritura propia que lo sostiene; y así también manifiesta su saber, su validez. Los distintos elementos que lo componen, el orden y selección de las ideas, no tienen otro sustento más que la unidad

\footnotetext{
${ }^{41} \mathrm{Y}$ va todavía más allá en su crítica, al decir que: "El ensayo no se limita a prescindir de la certeza libre de duda, sino que, además, denuncia su ideal" ( Adorno 24) y "Verdad porque, efectivamente, el ensayo no se cierra ni termina, y su incapacidad para hacerlo vuelve como parodia de su propio a priori; y entonces se le imputa como culpa aquello de que sólo son culpables las formas que borran cuidadosamente la huella de su arbitrariedad" (28).

${ }^{42}$ Es cierto también que el ensayista utiliza a la hora de escribir saberes anteriores sobre el tópico que trata, pero no utiliza las citas de autoridad para apoyar y reafirmar sus sentencias, sino que entra en diálogo con ellas y las toma como impulso de su escritura (Good 6). Ampliaré este tema en el capítulo 4, al analizar el uso de la cita por parte de Connolly.
} 
del yo que los propone. Dado que es una práctica descentrada, se libra de la exigencia de validarse por consenso; su legitimidad última descansa en la experiencia; por esto sus hallazgos no son generalizables más allá de su acontecer momentáneo dentro del ensayo; son tanto provisionales como personales. Al ensayista, en su ejercicio, no se le exige "un rol social autorizado por la institución" (Mignolo 221); queda avalado por su uso mismo, a través de la escritura, en el tratamiento de la cosa. En tanto partícipe de una cultura, la personalidad del ensayista se ofrece como un "universal particular" (Good 8), y su cometido es hacer "algo propio con lo propio" (Lukács 35). Me atengo a la completa formulación de Adorno:

Bajo la presión del espíritu cientificista y de sus desiderata, omnipresentes y latentes también en el artista, Proust, con una técnica imitada de las ciencias, en una especie de serie experimental, ha intentado salvar o restablecer lo que en los días del individualismo burgués, cuando la conciencia individual aún confiaba en sí misma y no se estrechaba anticipadamente bajo la censura de la organización, valía aún como conocimiento de un hombre experimentado del tipo de aquel desaparecido homme de lettres, tipo que Proust resucita aún como caso supremo de dilettantismo. A nadie se le habría ocurrido entonces considerar irrelevantes y rechazar como accidentales e irracionales las comunicaciones de una experiencia, sólo porque son las suyas y porque no son sin más susceptibles de generalización (Adorno 18).

En tanto no tiene restricciones genéricas ni institucionales, el ensayo se presenta como un espacio de libertad; esta misma indeterminación es la del hombre de letras, y por eso el ensayo se constituye en su práctica 'esencial'. Según Good el ensayista ideal debe ser desinteresado, sin estar su mirada contaminada por ningún trabajo o profesión $(11)^{43}$. Podríamos decir que el ensayista ideal es un hombre de letras, y que el hombre de letras ideal es un gentleman; su actitud desinteresada es antiburguesa, en tanto crítica de la virtud de la diligencia y la alabanza del ocio. Es un observador independiente, alguien contemplativo, pero, a diferencia de las representaciones que tenemos de monjes y académicos, alguien experimentado, maduro de experiencias.

Esta contemplación, amateur, independiente, es una forma del escepticismo, de la duda; si el ensayista no es propiamente un nihilista, es más un observador que un partidario; sus juicios conservan cierta reserva. Siguiendo a Hardison, creo que hay en la actitud del ensayista algo de ataraxia, una distante calma que debe interpretarse como un rechazo a quedar comprometido; así, una de las figuras que el ensayista interpreta es aquella que dio título a una de las publicaciones ensayísticas más famosas de Inglaterra,

\footnotetext{
${ }^{43}$ En esa idealización, el ensayista es "free temporally (he has leisure), spatially (he can walk and travel), economically (he has at least a "sufficiency"), but most of all mentally (he is unprejudiced, curious, observant about himself and the World, quick to respond to new experience and ideas)" (Good 11).
} 
The Spectator: el ensayista como espectador (Hardison 18). El espectador es aquel que no presta su conformidad, el que está afuera y observa. Pero esta observación, mediante la escritura, se vuelve activa, dado que el observador queda ligado a la cosa observada, se hace con ella y cambia con ella. El ser y su objeto se organizan, se configuran uno al otro en el mismo proceso de escritura; pero, en tanto proceso de búsqueda, esa configuración ocasional no se presta a la deducción de métodos o reglas (Good 4). Según la tesis de Hardison, el ensayo, en tanto género proteico, y postulando un saber escéptico, inestable, posee los elementos retóricos más adecuados (en contraste con los demás géneros, más fijos en su poética) para un mundo, o un tópico, que se ha vuelto problemático. Y en tanto búsqueda de un saber sobre lo cambiante, se trata de un proceso de autorrealización en un mundo sin orden. Un ensayo es siempre un enunciado inestable sobre un tópico determinado a la vez que una búsqueda de la respuesta personal ante ese tópico problemático: ¿qué se yo de esto?, pero también ¿qué hace/dice esto de mí? "Writing an essay is an exercise in self-fashioning" (25). Pero respuesta y autoconstrucción son en el ensayo siempre literarias.

Del ensayo como arte. Según la formulación de Good, el ensayo es a la vez la inscripción de un sujeto y la descripción de un objeto (23). La confianza que el lector le presta no radica en la impersonalidad de un método consensuado, sino en tanto respuesta particular ante un fenómeno particular ${ }^{44}$. La ocurrencia de ese postulado circunstancial y momentáneo es una idea por esencia inaplicable, dado que la experiencia del ensayista no está regida por leyes conocidas. La verdad del ensayo es una verdad limitada, limitada por la experiencia concreta, ella misma limitada, que le sirve de sustento; "the essay is a provisional reflection of an ephemeral experience of an event or object" (Good 7). En esta caracterización recíproca que se da entre el sujeto y el objeto, lo importante es la configuración. Porque el ensayo, en su escritura -y en la conciencia de la escritura- no se rige por los moldes de la ciencia o de la lógica, sino por la estética. Se trata de un conocimiento estético, organizado estéticamente. Si bien sus observaciones se basan en la experiencia (no son ficcionales en el sentido en que una novela lo es, se trata de un pacto distinto), éstas pasan por el tamiz del arte. Entre el

\footnotetext{
${ }^{44}$ Así lo piensa Barthes en su artículo "Mucho tiempo he estado acostándome temprano", donde se refiere a la crítica como una experiencia de búsqueda; y esa búsqueda no puede sino ser la de la literatura cuando afecta su cuerpo. Así, el crítico acepta erigirse en mediador de la literatura, formulando, a partir de movimientos personales, algún rasgo fundamental. Es la búsqueda de una Scienza Nuova que se hallaría en la "cima de la particularidad" (Barthes 1987: 339).
} 
arte y la ciencia, el ensayo da un tratamiento artístico a ciertos materiales que de otra manera pueden ser estudiados científica o sistemáticamente (15); sobre todo, materiales que con el tiempo y los cambios de paradigmas han sido apropiados por las distintas ciencias humanas. Así, el ensayo moral es hoy el campo de la psicología, el ensayo político, de la sociología, etc. En ese sentido, el ensayo literario sobrevive con una legitimidad distinta: en tanto la literatura es un arte; el tratamiento artístico de la misma, según la experiencia estética del ensayista, es un proceso válido en cuanto utiliza sus mismos materiales y procedimientos, interpelando a la literatura según su modo (Giordano 2005: 223) ${ }^{45}$. Si bien el saber que el ensayo literario presenta debería tener una validez incuestionable (quién pudiera desestimar los aportes al saber literario, y al desarrollo de su campo específico, de ensayos como "Kafka y sus precursores" o "Las versiones homéricas" de Borges), existe, sin embargo, un conflicto de "retóricas", podríamos decir, con el discurso validado por la academia, con su propensión teórica y sistemática.

Como Proteo, el ensayo cambia, se transforma en cuanto se lo trata de asir. Su nacimiento por fuera del sistema clásico de los géneros literarios no pudo evitar, sin embargo, su final inclusión. Pero entonces, en tanto género literario, el ensayo es una forma artística y, si está genéticamente relacionado con el saber y la experiencia, el conocimiento que presenta se juzga bajo las formas del arte; es un conocimiento estético de un objeto subjetivizado por la escritura del ensayista que se construye interrogándolo. El hombre de letras, en su amateurismo e independencia, y el ensayo en tanto es su práctica genuina, saber particular y descentrado, si no han sido invalidados por los estudios institucionalizados, ostentan por lo menos la misma legitimidad problemática.

\subsection{Particularidad de los ensayos de Cyril Connolly}

Los tres ensayos de Connolly que voy a comentar aparecieron con ocasión de la muerte de los autores tratados. Se trata en este caso de 'retratos literarios', a la manera de los de su admirado Sainte-Beuve. Si bien, según adelanté, la producción de Connolly abarca distintos subtipos de ensayos, éstos son característicos de buena parte de su producción, y me permito hacer este recorte para deslindar sus modos particulares, con la seguridad

\footnotetext{
${ }^{45}$ Junto al ensayo literario, son el ensayo autobiográfico y el ensayo de viaje los que mejor han sobrevivido, en tanto no son reclamados por ninguna ciencia establecida.
} 
de que en los próximos capítulos analizaré otros subtipos que amplíen el conocimiento de su obra.

\section{Joyce. El mamut (1941)}

Joyce acaba de morir esa misma semana en un hospital de Zurich y Cyril Connolly, ya un crítico reconocido, se dispone a hacer una semblanza del autor y su obra. Sin embargo, parece desligarse de la responsabilidad de una profunda valoración crítica, alegando que Edmund Wilson ya lo hizo de manera insuperable en cuarenta páginas de su El castillo de Axel (1931). A pesar de eso, en el mismo párrafo, Connolly profetiza para Joyce el lugar de Precursor de moda para la siguiente generación, haciéndolo suceder nada menos que a Henry James. Luego, introduce uno de esos conceptos suyos tan personales: Joyce fue el último de los mamuts -con la excepción de algunos franceses, entre los que está Gide-.

Por mamuts me refiero a esos gigantes miembros de las clases medias que creían en vivir por y para el arte, y no les importaba dedicar sesenta o setenta años de energía y paciencia inagotables, todo su tiempo, todo su dinero, todos sus pensamientos a él. (Connolly 2005: 708)

Las guerras son sucesivas glaciaciones para estos artistas que, disfrazados de burgueses, alimentaban su obra con la "experiencia obtenida a lo largo de toda una vida gracias a una inmensa curiosidad, rentas personales y una profunda sensación de seguridad" (709). Una constante del humanista oxfordiano Connolly, como hijo de las guerras, es profetizar la decadencia y crearse a su vez como defensor y último ejemplar de una cultura que desaparece: "Ahora la mayor parte de ellos se ha ido, y los hielos vuelven con gran velocidad" (709).

Uno de los procedimientos críticos preferidos de Connolly, a semejanza de Hazlitt, es el establecimiento de dicotomías o elementos contradictorios cuya compleja combinación dará lugar a los hechos estéticos de su admiración. Dublineses (1914) y El retrato del artista adolescente (1916) se presentan así como una elaborada síntesis de las dos venas que dominan a Joyce: el realismo del 'movimiento moderno' y un decadente romanticismo celta. 'Admirable' es el epíteto para la primera obra; en el caso de la segunda, éstos rozan lo superlativo: extraordinario, maduro, sensible, inquietante. Los conceptos de moderno y romántico, asociados a los de vernacular y mandarin, son las categorías estéticas que Connolly había utilizado para hacer un balance (y una crítica) de la prosa inglesa en su libro Enemigos de la promesa (1938). En el mismo 
libro de ensayos, en su parte autobiográfica, estas dicotomías hacían presa del propio Connolly, configurando su carácter (es decir, su modo de presentárnoslo) y la lucha por su estilo. Vemos así como lee en Joyce la posible resolución de su propia ambivalencia estética.

Leyó Ulises (1922) con pasión mientras se convertía en una obra de culto; y pasa a comentar: "es en gran medida un libro para jóvenes, lleno del derrotismo y la culpa de la juventud, con su soledad, cinismo, pedantería y estallidos de obscena actividad anarquista" (todos elementos que, a lo largo su obra, Connolly dice detestar en sí mismo, y, sin embargo, siempre se encarga de resaltar); “era, y siempre será, algo totalmente diferente a lo que uno ha leído antes" (710).

Este libro consagró a Joyce y le permitió llevar la vida que deseaba, la de sumo sacerdote del arte, en un lujoso departamento parisino: “Allí es donde yo le solía visitar", nos dice Connolly, "cuando me encontraba escribiendo un artículo sobre Ulysses y Work in Progress" (710). A partir de aquí el ensayo fluirá entre los recuerdos y la caracterización; intimidad con la obra e intimidad con el autor ya son una y la misma cosa. La anécdota superflua, chistosa, se vuelve disimulada crítica: Connolly acude a Joyce porque necesita que le explique algunos pasajes de Finnegans Wake; Joyce lo obliga a interpretar, pero luego, ante la inmensa vergüenza de un Connolly desacertado, suelta la interpretación verdadera, indescifrable, extravagante y, quizá, algo ridícula. "No era tanto como estar en el colegio, sino como desayunar, acabadas las clases, con tu profesor. En teoría era un adulto; en la práctica, no" (711).

Sobre ese Joyce, tan irlandés, snob, borracho, amante de la comida, "la ópera, y el orden, y el dinero" (711); sobre ese Joyce, cuya espléndida voz oyó acompañar el piano, que parecía ser dos personas: el legendario Joyce, ciego, frío, distante y por debajo el simpático y descarado dublinés, Connolly concluye

Nunca tendremos en nuestras vidas el tiempo, la seguridad o la paciencia para escribir como él. Sus armas, "el silencio, el exilio y la astucia", no son las nuestras. Sólo espero tener tiempo de leerle penetrando en su escritura y poder hacer un día un estudio de este anti-Pope literario [...]. (712)

\section{Hemingway. El Titán (1961)}

Si con la muerte de Joyce se perdía a uno de los últimos Mamuts, con Hemingway se fue un Titán. Aproximación conceptual:

Poseía la energía, la resistencia, la grandeza personal de la categoría de los Balzac, Stendhal, Flaubert, Tolstoi. No creo que fuera un gran novelista, pero estaba hecho 
del material del que se hacen los grandes novelistas, un Titán que todavía podía convertirse en un dios. (732)

El hecho, sin embargo, no puede apuntarse en su debe: "Hasta tal punto eligió representar a su época que nunca pudo escapar a sus limitaciones" (732). Otra vez la introducción de conceptos tan caprichosos como originales, que tratan de fijar al autor y a su época, a la vez que denotan una manera de enjuiciar el arte muy propia de Connolly. Lo que parece reducción y arbitrariedad, es en realidad principio de lectura productiva e imagen cierta, si no verdadera.

"Lo que le preocupaba [a Hemingway] era captar la esencia poética de su propia experiencia, no la construcción de una novela como una obra de arte que le impusiera sus propias normas" (732). La lectura del error, lo que acusa la falla, es a la vez el elemento particularizador y atrayente (Grüner 14). Como en el caso que mencionamos anteriormente, Connolly vuelve a leer su propio error, a denunciar su práctica ensayística y sus obsesiones; tal vez la única diferencia sea la magnitud del fracaso. Así, el núcleo de la genialidad de Hemingway es para Connolly "su posición como poeta romántico en el siglo XX" ${ }^{46}$ (Connolly 2005: 733); la experiencia que quería comunicar -fatalmente su experiencia- podía entrar en distintos modelos: poema en prosa, libros de viajes, periodismo, ensayo; pero por encima de todo, encontró su medio en el relato (Connolly prefiere "Las nieves del Kilimanjaro", relato autobiográfico tan profundo y complejo como una novela, que, ante la muerte de Hemingway, tiene una tristeza profética) (733). Connolly se perfila, a través de él, como el practicante que, igualmente dotado, no pudo - por pereza, por un error de carácter- hallar su forma en un arte mayor.

Todos los relatos de Hemingway, nos dice, se basan en la relación del hombre con la muerte: las guerras; los toros, la pesca y la caza mayor; los gangsters en tiempos de paz; pero no hay mención del tenis, que a Hemingway le gustaba mucho, porque no encierra ningún peligro (734); Connolly detecta una "imaginación irresistiblemente atraída por lo macabro, una característica común entre los genios" (735).

En una estructura libre, que semeja pero no repite la utilizada con Joyce, pasa cuenta a su vida y sus libros, a las hazañas de guerra, a los bellos atributos físicos de Hemingway ("Hasta entonces nadie tan musculoso y atlético había llegado a sentarse a los pies de Flaubert, Joyce, Pound o Gertrude Stein”, 736); pero lo que más le interesa

\footnotetext{
${ }^{46}$ Para las relaciones de Connolly con el romanticismo véase MURAT, Jean-Christophe. "The Cost of Myth: Cyril Connolly and Romanticism" en The Space Between: Literature and Culture, 1914-1945 Volume 4: 1, 2008. 101-122.
} 
destacar - debida la obsesión de ambos con el estilo- son sus aportes al arte de escribir: "un perverso don satírico y un sentido lírico de las palabras, de su ubicación y su tempo"; "sus diálogos, que son fluidos, naturales e inevitables, fueron una aportación propia" (736). Para concluir:

Nadie ha escrito con más conocimiento sobre la muerte repentina, ni con más poesía sobre los placeres físicos y la alegría de vivir, nadie ha trabajado tan duro para dar a su prosa una nueva dimensión, una prosa que él creía que nunca se podría escribir, 'sin trucos y sin hacer trampa. Con nada que se pueda pudrir más tarde'. $(739)^{47}$

Por último, le gustaría a Connolly darnos una antología ilustrativa; a falta de espacio, nos presenta la lista de sus contenidos. No cedo a la tentación de reproducirla, pero me parece pertinente dar cuenta de algunos de sus particulares criterios: tal página, porque la reescribió muchas veces; un capítulo, porque es un inventario de la amada España; dos capítulos suprimidos, para que los podamos leer; digresiones sobre París; "muchos, muchos relatos" y su "extraordinaria entrevista en el Paris Review entera" (739). La lista, procedimiento del que Connolly es obsesivo confeso, se presenta así como último grado del gusto, la preferencia casi en estado puro; la radiografía, por coordinación, del lector.

\section{Eliot. La Literatura (1965)}

Esta vez no nos enfrentamos a un concepto animal o mitológico, sino a la carta del propio Connolly a un compañero de Oxford, fechada cuarenta años antes:

"Pase lo que pase, lee The Waste Land, de T.S. Eliot, pero léelo dos veces. Es muy corto y contiene las cosas más maravillosas -aunque el mensaje es casi ininteligible y es un poema muy alejandrino- la esterilidad disimulada por un extraordinario uso de las citas y un oscuro simbolismo -totalmente- decadente. Arruinará tu estilo...". (Connolly 2005: 719)

Asistimos a la impresión inmediata que el poema de Eliot causó en el lector; asistimos mediante esta intrusión discursiva- al desborde inaugural, a la vez que Connolly se habilita como el-que-estuvo-ahí, desde siempre, y la escritura se vuelve sucedánea de la lectura apasionada. "Y es que ¿cómo expresar el auténtico lavado de cerebro, la fascinación absoluta, el estado de alucinación y la obsesión que este nuevo poeta provocó en algunos de nosotros?" (719). Y no, esa lectura, esa pasión, no puede ser

\footnotetext{
${ }^{47}$ Apreciación coincidente con la de Borges: "Hemingway, como Kipling, se veía a sí mismo como un craftsman, un escrupuloso artesano. Lo fundamental, para él, era justificarse ante la muerte con una tarea bien hecha." BORGES, Jorge Luis, en colaboración con ZEMBORAIN DE TORRES DUGGAN, Esther. Introducción a la literatura norteamericana. Buenos Aires: Emecé, 1997. Pág:83.
} 
expresada en sí; el ensayo se vuelve así la alfombra roja que lleva hasta el placer del texto; puede dar testimonio de la experiencia, con la ilusión de atracción y contagio; puede bordearla, sin nunca reemplazar a la experiencia misma. Aquí es donde el ensayo se vuelve autobiografía, en tanto recuerdo de la fruición de la lectura primera, y no como protocolo de lectura; el ensayista como quien gustó del texto y relata la experiencia.

El ensayo nos presenta a dos Eliot: el de los primeros poemas, el de The Waste Land (1922), que Connolly lleva hasta la nacionalización británica y conversión religiosa (1927);

el apuesto pagano de Harvard con su atractivo arlequinesco, su expresión luminosamente luciferina, de quien nadie podía averiguar nada excepto que era pobre e infeliz, que había trabajado en un banco y a veces se quedaba en el vecino Garsington. (720)

Sus poetas favoritos ya eran Dante y los isabelinos menores; por entonces nadie sabía cuánto le debía a Laforgue. Connolly, invirtiendo el lugar común de la crítica, destaca la deuda que Pound, el del "Homage to Sextus Propertius" y "Mauberley", tiene con Eliot. "Siempre acabo por volver al primer Eliot y su poesía", confiesa; al que, junto a Pound, produjo la revolución poética, incorporando a la poesía la vida urbana y su habla, "para luego mirar atrás, por encima de los cadáveres aniquilados de los georgianos, a su propia visión del pasado tradicional [...]” (722).

El otro Eliot es el de las obras teatrales, el que compuso "dos obras maestras "Ash Wednesday" y Four Quartets (723) ("el poema unitario más importante de la primera mitad del siglo XX”, 724), el que reinó como crítico, si bien Connolly opina que en esta época "la prosa de Eliot perdió esa calidad centellante, cáustica, que fácilmente pasaba a ser árida y en ocasiones a pontificar, aplastada por los honores y la autoridad ex cathedra que la sociedad le había concedido" (724). Este Eliot, el sacristán adicto a los gatos y catador de quesos, se podría decir que encarna la Literatura, sus tradiciones y saberes ${ }^{48}$ :

A menudo me ha reconfortado la mera idea de que él estaba por aquí [Londres], como se sienten los súbditos leales cuando ven que el pabellón real ondea sobre palacio. (721)

Durante la guerra de pronto descubrió que se le consideraba una de las cosas por las que luchábamos, como las cuatro libertades o el Big Ben. (724)

\footnotetext{
${ }^{48}$ Figura que para Pound encarnaba Henry James, para Valéry, Mallarmé y para Piglia, José Bianco.
} 
Finaliza Connolly como había comenzado, con la nota personal. Esta vez, Eliot le escribe para agradecerle el comentario de una antología; Connolly es llamado "el primer lector y crítico comprensivo que se fijó en el hecho inusual de que al fin había escrito un poema de amor y de felicidad" (726). Y dice el ensayista haber llegado a su momento cumbre al dar una fiesta para Eliot, con ocasión de su Premio Nobel; leyeron poemas juntos. Ahora, ante su muerte, sólo dice esperar que se publiquen sus cartas, para llegar a conocer mejor a este "mártir y confesor del deseo de perfección” (726).

Los ensayos de Connolly que comenté se delinean como retratos literarios que, a la manera de los de Sainte-Beuve, mezclan las anécdotas con la reflexión, construyendo una imagen de los autores a partir de la familiaridad con su obra. Esa vida recreada ante nosotros tiene el tenor de la vida literaria. Connolly despliega estas vidas de sus maestros contemporáneos, ya vistas como destino, puntuando en ellas las huellas del arte, errores y aciertos que particularizan lo que ya para él no son libros sino obras. Y es que Connolly se piensa, y se escribe, en su potencial de autor más que de crítico; la fijación de Connolly como escritor son las posibilidades de construcción de la obra, los materiales, vitales y estilísticos, necesarios en un arte de escribir. Tal vez, si no hubiese estado obligado a ganarse la vida en el oficio de reseñador, Connolly hubiera cumplido (tras algunos fracasos luminosos) el ideal del escritor que no escribe, paralizado por la lucidez, fascinado por la escritura. Podemos aplicarle las palabras que Harold Bloom dedica a Ruskin: "La reverencia, la sensibilidad, la precisión... tomadas en conjunto, son las virtudes teologales del crítico, pero su combinación puede truncar la creatividad" (2010: 202).

Con todo lo reductor que puede parecernos, crearse una figura literaria es también asumir un estereotipo; los que Connolly eligió para sí son un buen tamiz para leer sus ensayos: Connolly representa al crítico en cuanto escritor fracasado, el hombre de letras que estaba hecho con los materiales con que se hacen los grandes escritores pero no pudo serlo; la eterna promesa, de quien se esperaba la obra maestra de su generación: sus ensayos pueden leerse como la búsqueda de esa falla, y como una expiación. Lo que parecen meras anécdotas son escenarios donde se despliega la vida del artista, hábitos, decisiones y estilos que hacen posible la obra; Connolly establece incansablemente las condiciones de posibilidad de la escritura para leerse en su falla. El relieve de lo superficial se manifiesta en la imbricación ejemplar de estas vidas escritas 
en la creación de la obra; la tan mentada relación vida-escritura es tratada como un vaivén donde una es la posibilidad de la otra, el escritor en cuanto cuerpo para la obra.

El romanticismo celta que amenaza a Joyce, con su juvenilismo, pedantería, culpa y derrotismo; la no-sujeción de Hemingway a las exigencias normativas del arte de novelar a favor de una recreación lírica de la experiencia, son errores que Connolly lee en sí mismo en otros ensayos y que ahora se proyectan: el romanticismo juvenil de su exclusivísima educación, que lo dejó anclado en aquella edad y en sus vicios; la pereza proverbial que le niega las posibilidades del arte mayor (como el estudio que promete aquí sobre Joyce, otro sobre Flaubert del que se gastó los anticipos editoriales, la continuación de su autobiografía). Este proceso de autofiguración de Connolly, entre errores y aciertos proyectados, entre anécdotas y juicios, es el despliegue de los materiales y técnicas con que pensó construir su obra, y que al fin son la obra misma; nunca mejor aplicada la afirmación de Piglia: "La crítica es la forma moderna de la autobiografía" (2005: 141).

Un examen riguroso nos podría hacer sentir que Connolly dice bastante poco del Ulises o que es injusto y parcial; y que la antología de Hemingway es bastante caprichosa, si no coincide con nuestra lectura del autor, o con las valoraciones más corrientes y fundadas. Pero el ensayo en Connolly es siempre experiencia, y exaltación de la experiencia de un sujeto que no se pretende ausente del texto, sino todo lo contrario; su autofiguración se hace posible en los libros que no pudo escribir, como si escribiera una autobiografía indirecta, y una obra, a través de los libros ajenos, de la afirmación de una vida solamente literaria, de un puro deseo de literatura. Fiel a la tradición del ensayismo inglés que vengo desglosando (Johnson, Hazlitt, Pater, Wilde) nada es más ajeno al proyecto de Connolly que pretender la reducción del yo en la crítica literaria; su poética podría ajustarse a las "verdades impopulares respecto a la naturaleza de un estilo de crítica verdaderamente literario" que formula Harold Bloom: "Este debe basarse en la experiencia, debe ser -al menos en parte- empírico o pragmático y debe sustentarse en el amor por su tema ${ }^{49}$; sobre todo, no debe ajustarse a ningún método salvo a la personalidad del propio crítico" (2010: 127-128).

\footnotetext{
${ }^{49}$ Me tomé el atrevimiento de corregir la traducción, dado que el original dice: "it must be informed by love of its subject", lo que la traductora había interpretado como: "debe informarse mediante el amor al sujeto"; algo que, siendo correcto, se presta al equívoco.
} 
A esta práctica del ensayo como lenguaje de experiencia, debemos sumarle en Connolly la afirmación del estilo. Si el estilo es la fatalidad de lo particular, en Connolly se traduce como el cuidado de sí a través de la escritura. Su temperamento perfeccionista se refleja en el pulido del fragmento; el indagar constante en la escritura como arte, su escribir sobre la escritura, sugieren un conocimiento de primera mano de la excitación y las dificultades que ésta requiere, a la manera de un artesano miniaturista. Connolly se piensa a sí mismo, hasta en las reseñas que tanto cuida y repudia, como un practicante de las bellas letras, un defensor de la buena escritura. Este cuidado, tal vez la mera preocupación de la escritura como arte, hacen que hasta los escritos más 'efímeros' de Connolly aspiren a la condición de literatura -la única que en definitiva le interesaba-, aun consciente de la marginalidad de su práctica: "Nunca escriba una crítica que no pueda ser reimpresa, es decir, que no tenga cierta longitud y trate un tema de valor permanente" (Connolly 2005: 160), aconsejaba a un aspirante a crítico.

De los ensayos de Connolly podría decirse que en ellos siempre hay 'alguien', alguien que lee y escribe y nos acompaña por los textos mientras se va creando; alguien que no escatima el uso de la primera persona porque cree que la crítica, después de todo, es una cuestión de preferencias; nada más ajeno a Connolly que borrarse de sus lecturas, si justamente lo que pretendía era encontrarse y configurarse a través de ellas. En su obra se pone de manifiesto una afirmación de las potencias del individuo y la escritura, un quehacer ajeno a lo sistemático, a la aplicación teórica; la práctica crítica como la postulación de una lectura a través de las figuraciones de un hombre que lee. Como afirma Nora Catelli: “el Yo de Connolly existe porque ha leído" (2005). Lo que podemos llamar su gusto se forma en la prolongada frecuentación de la literatura clásica y moderna, que desde temprano le fue accesible por privilegios de nacimiento $\mathrm{y}$ educación $^{50}$, en la constante agonía de la escritura y sus exigentes, hasta casi el silencio, deseos de la obra.

Sabemos que el gusto no es un instrumento universal de juicio, si los hay, y también sabemos que el ensayo no se los propone; el gusto se conforma de "ciertos valores que un escritor afirma sobre la literatura desde su propia literatura" (Lopérgolo 78), o desde lo que desearía que ésta fuese, y no fuese. Si tomamos como valores

\footnotetext{
${ }^{50}$ Como tendré la oportunidad de analizar más adelante, éstos son elementos esenciales para la formación del gusto en autores como Hume y Bourdieu.
} 
cardinales de la crítica lo exhaustivo, lo profundo, lo objetivo, los escritos de Connolly se nos presentan como las notas marginales de un diletante caprichoso; si nos abrimos a otros disfrutes, los escritos de Connolly recuperan la elegancia y ligereza del ensayismo inglés (tan caro a cierta tradición del ensayismo argentino). El ensayo es, en la obra de Cyril Connolly, el escenario de autofiguración de un hombre de letras, de una vida vivida a través de lo leído y lo escrito, su relato de amor, y aparente fracaso, con la literatura; una manera de conversar sobre libros. 


\section{Cyril Connolly, ensayista autobiográfico}

\subsection{En torno a la autofiguración}

Ya sea en retratos de autores, en valoraciones de libros, como en los diversos ensayos que Connolly escribió para diarios y revistas, la característica patente a simple lectura es esa acentuación de lo particular. Estos escritos (no me voy a ocupar ahora de sus dos obras mayores, Enemigos de la promesa y La tumba inquieta) parecen tener un impulso irrefrenable por la autorrepresentación, que se vuelve así marca estilística. Todos ellos, en una lectura conjunta, serían al fin el retrato de los componentes diversos de un autor, o del fracaso de una vida literaria. Sus ensayos no sólo permiten la mirada del autor, su intrusión, sino que más bien son escenarios para distintos procesos de autofiguración. Uso este término en el sentido que lo utiliza José Amícola: "Se denominará 'autofiguración' [...] a aquella forma de autorrepresentación que aparezca en los escritos autobiográficos de un autor, complementando, afianzando o recomponiendo la imagen propia que ese individuo ha llegado a labrarse dentro del ámbito en que su texto viene a insertarse" (Amícola 14). Pero es cierto que voy a ampliar su campo de uso, porque lo particular de Connolly es que estas formas de autorrepresentarse no figuran sólo, ni mayormente, en escritos autobiográficos, sino en ensayos y artículos sobre tópicos muy diversos. Se trata de textos sólo tangencialmente autobiográficos, o que utilizan elementos de la autobiografía en tanto género privilegiado del 'yo', pero su finalidad primaria o aparente, su aspiración, no es la autobiografía.

El humanismo que en el Renacimiento vuelve a implantar las especulaciones en torno al hombre, dando condiciones de posibilidad al surgimiento del ensayo, implanta un espíritu de individualismo donde comienzan a producirse ciertas escrituras del yo, "relatos no directamente ficcionales en los que puede tratarse de un Yo que cuente su experiencia vivencial a partir de claves convencionales" (16). Algunas de estas características embrionarias, que irán ampliándose hasta tener su eclosión en el s. XVIII, tienen que ver con la vuelta a la filosofía grecolatina y el desplazamiento del teocentrismo filosófico de la Edad Media. Hay un fortalecimiento de la idea de sujeto, librado a sí mismo en tanto ser solitario, que diferencia la esfera pública de la privada, y que, mediante la introspección, se embarca en la búsqueda y la construcción de su propia identidad ante un mundo que ya no ofrece la seguridad de las estrictas jerarquías sociales ni el determinismo de la fe religiosa. El florecimiento de las escrituras intimistas es consecuencia y síntoma de esta nueva inestabilidad gnoseológica, deudoras 
de un sujeto que se construye a la vez que busca establecerse ante un mundo sin orden, o de un orden antes desconocido.

Cuando el autor se escribe a sí mismo, por tanto, no se trata de un mero acto de representación, dado que "la propia instancia de narrar es forjadora de identidad" (Egan, citado en Amícola 25). Tanto cuando narra la historia de su personalidad, como su acontecer emocional y psicológico pasado o presente, construye, en su sentido más creativo, una imagen de sí. Si bien puede que, según las distintas intenciones de autores diversos, el impulso principal de esta tarea sea introspectivo, donde el escritor escribe para conocerse, tratándose de textos creados con el fin de publicarse, nunca está ausente la mirada del otro; se trata, también, de una imagen de sí para otro. Es más, en tanto se observa para escribirse, en tanto objetiva su subjetividad, el sujeto también es otro de sí mismo; por eso es que no hay sujeto anterior a esa escritura, dado que se constituye a sí mismo a través de ese orden simbólico: se trata de un acto performativo (Amícola 31). Y si la imagen de sí es la que preside el proyecto, esa imagen también es siempre un artefacto social, "tan revelador de una psique como de una cultura" (Molloy 19). Más allá de que exista en la referencia una tendencia hacia la autenticidad -y en eso se basa el pacto de lectura autobiográfico-, ese Yo que se narra es una figura múltiple, problemática y no esencial, dado que no existe fusión total o identidad del Ser y su imagen; existe "algo que ahora se individualiza cada vez más como la 'imagen de autor' o la 'persona', es decir el 'Autor' como una construcción pública creada por cada escritor para el uso exterior" (Amícola 27).

El autor crea así una imagen íntima a la vez que pública; mediante los procesos escriturarios de autofiguración construye una imagen pública que de algún modo intenta coincidir con la que el autor tiene para sí. Pero dado que ofrece a la lectura una imagen de sí, esta debe ser 'justificada’; ¿por qué, si no, ofrecerse? Todo proyecto que sea autobiográfico en cierta medida debe contener su propia autojustificación, debe probar el interés que viene a satisfacer" ${ }^{51}$ : "La autobiografía es una forma de exhibición que solicita ser comprendida, más aun, perdonada" (Molloy 17). Según Molloy, este perdón tiene un doble sentido: que se perdone al autobiógrafo, en el sentido de que se lea su vida con simpatía; y que se posponga el juicio, la condena, en tanto que en su acto de trasgresión el escritor pone en manos del lector el poder del indulto, se vuelve vulnerable en tanto entregado; "hay a menudo la sospecha de que algo se ha hecho mal"

\footnotetext{
${ }^{51}$ Tampoco debe olvidarse, a la hora de analizar esos intereses, la función que este tipo de textos ocupa o intenta ocupar en la obra general del autor estudiado.
} 
$(17)^{52}$. Cuando Friedrich Schlegel (citado por Amícola en su estudio, 18) reflexiona en un fragmento de la revista Athenäum sobre las distintas razones que llevan a alguien a escribir su autobiografía, menciona, entre otras posibilidades: los enfermos mentales, presos de su Yo; el artista o aventurero, como ególatra ideal; los historiadores, que se toman como material; mujeres que ansían la posteridad; aquellos que quieren poner orden en sus recuerdos antes de morir sin publicaciones; los 'autopseutas', aquellos que se engañan a sí mismos. En fin, como concluye Amícola:

Podría decirse que la principal cavilación de Schlegel rondaba en torno de qué tipo de obsesión consigo mismo debía estar presente en el autobiógrafo para hablar con semejante contundencia sobre sí y considerar que esa concentración ególatra sería materia de interés para los posibles lectores. (19)

En tanto selecciona los materiales de su vida que quiere dar a conocer, y los ordena de modo que cumplan la función que él desea -que contribuyan a la idea de sí que quiere armar para el otro-, toda escritura autobiográfica emplea, más allá de la tensión que produce la no ficcionalidad de sus referencias, los recursos propios de las obras literarias, y como tal puede ser considerada y analizada. Existe un importante componente basado en el poder de la memoria, pero se trata de una memoria dirigida desde un presente donde el escritor tiene una idea singular de sí mismo que quiere plasmar. Documentos y obras de artes, se trata de una tensión irresoluble, dado que el texto no puede mostrar lo que el narrador era, sino lo que desea que se sepa de lo que él ahora cree que era: "La evocación del pasado está condicionada por la autofiguración del sujeto en el presente: la imagen que el autobiógrafo tiene de sí, la que desea proyectar o la que el público exige" (Molloy 19). De estas distintas negociaciones, poniendo el énfasis más en unas instancias que en otras según los casos, pero sin poder evitar ninguna, surgirá la figura de autor; una figura que no puede ser anterior al texto, porque, en definitiva, se trata del "esfuerzo por imponer un Yo, nacido exclusivamente en el espacio de la escritura, haciendo de esa ausencia una presencia" (Amícola 17). Lo que el sujeto recuerda depende de la codificación que para sí ha tenido ese pasado, siempre que se trata también del relato de esos hechos que él se ha hecho a sí mismo, y, en tanto relato, no se trata de una copia literal del pasado, sino del resultado de una interpretación de ese pasado. La 'sinceridad' de esos recuerdos, fundante de un pacto de

\footnotetext{
${ }^{52}$ No debemos olvidar que los inicios de la escritura autobiográfica pueden ligarse al sentido religioso de la confesión, donde el sentimiento de culpa funciona como impulso de escritura, siempre que, como señala Amícola, quien se acusa se excusa (42).
} 
lectura singular como es el autobiográfico, sin faltar a la verdad, no tiene por qué coincidir con lo que podemos denominar 'real'.

En el s. XX, como consecuencia de una progresiva desintegración de la esfera pública, comienzan a darse diversas manifestaciones de intimidad discursiva, no ya como afirmación del individuo autónomo ante el estado y la sociedad, sino en tanto inmersión en las profundidades del yo, lo que Nora Catelli llama "psicologización del yo" (18). Ese yo no es el del ciudadano, el ser público que se define en su posición social, sino uno que se busca a sí mismo, sabedor de las tendencias inconscientes que también lo animan. Ante esos impulsos que parecen negar la unidad del yo en tanto ser, el escritor intenta recomponer una imagen; los textos, y las imágenes resultantes, se unifican mediante un punto de vista, deudor de un nombre. La unidad de ese nombre, de esa intimidad que se aglutina alrededor de ese nombre, no deja sin embargo de ser imaginaria, porque el sujeto ya no puede, de forma inmediata, conocerse a sí mismo; el sujeto que se desconoce es quien asume y actúa su yo (10). Lo íntimo del ser es construcción, construcción imaginaria de un individuo que se relata su yo para ser.

No obstante, ese yo, en tanto escritor, intenta ser algo que él busca o cree de sí mismo para los demás. Por más íntimo que sea su discurso no deja de ser público en tanto texto y comunicación. Por tanto, hay una imagen para sí y de sí que el autor presenta a su público lector pero también una imagen que lo ubica, o busca ubicarlo, en las interrelaciones propias de su campo. "El imaginario de un escritor es, también, la construcción de una imagen de sí en el espacio literario, y su estética, la forma que da a esa imagen" (Alain Viala, citado en Gramuglio 40). Estas imágenes son en ese sentido estratégicas: estrategias discursivas y estrategias de escritor ${ }^{53}$ que se autoimplican para articularse en un proyecto literario a la vez que hacen patente el sistema de valores y creencias en cuanto a la función de la literatura y del escritor (Gramuglio 45).

\subsection{Ensayo y autofiguración: problemáticas y modos}

En el sentido que venimos tratando, el ensayo no ha sido el género privilegiado del yo. Las 'historias de vida', ya desde el Renacimiento, comienzan a plasmarse dentro de subgéneros convencionales que alcanzan nuestros días: las memorias, que abarcan un

\footnotetext{
53 "La noción de estrategias de escritor designa el conjunto de operaciones -discursivas y no discursivasque los escritores realizan para hacer carrera; son estrategias que ponen en juego el estatuto social del escritor y definen, de acuerdo con las posibilidades que ofrece el campo, clases de trayectoria literaria" (Gramuglio 45).
} 
período determinado de la vida del narrador; el diario íntimo, como presente del yo en su acontecer cotidiano; la novela autobiográfica, que aplica los procesos ficcionales; y, sobre todo, la autobiografía, que a diferencia de las anteriores no se centra en los eventos exteriores al narrador, sino que se concentra en los sucesos interiores del yo como elemento central de la narración (Amícola 16). Sin embargo, y aunque no se trate de su finalidad primaria, considero que en el ensayo, en sus características à la Montaigne, se da una emergencia directa o presencia del yo en primer grado. El tópico tratado queda ligado en su construcción a la voz de ese yo que se construye en el texto y que se presenta como sujeto de experiencia de ese mismo tópico; el sujeto no se oculta, porque es el cuerpo de la experiencia sin el cual la escritura quedaría sin fundamento. En el ensayo, más allá de la validez general que puedan o no tener las ideas expresadas, es el yo en tanto sujeto de lo acontecido el único garante de la posibilidad de lo expresado. Al igual que en los otros textos del yo, no es el tópico, objetivado por la transparencia del método o la mirada, el punto central o centrípeto, sino el yo con el que esos objetos u acontecimientos quedan implicados en tanto han convocado su escritura. Mientras que la validez experimental de los predicados de la ciencia es exterior al sujeto, dado que se basa en un método no personal, consensuado intersubjetivamente, en el ensayo el fundamento último y único se encuentra en el interior del sujeto experimentante: esto es válido porque yo lo digo, y yo lo digo porque me pasó a mí, lo experimenté en mí.

Como afirma Alberto Giordano no hay "ninguna superstición más extraña a la ética del ensayista que la de la objetividad, el deseo de volver insignificante el propio discurso para que, por él, la realidad (de las obras, de los autores) hable" (Giordano 2005: 242). El especialista escribe amparado por la unidad de la disciplina que lo delimita y la seguridad del método empleado; se borra de su discurso para construir una ficción de objetividad, amparada ésta en la ficción de la transparencia del lenguaje.

Asumir en el ensayo el imaginario y la escritura, se da así en el saber la aparición fundante del sujeto; el yo, de lo contrario, suele ser lo que está silenciado en el texto. Mientras el especialista desatiende u oculta la emoción o convicción que sobre el objeto tiene, el ensayista no hace más que ponerlas en relieve. Y un elemento básico de esta puesta es el recurso a la primera persona del singular, o lo que Giordano llama "método dramático", que pone en escena una enunciación y no una reflexión, que simula un discurso en lugar de describirlo (2005: 242). Se da así a la lectura una perspectiva, deudora de un valor: no se pregunta ¿qué es eso?, sino ¿qué es eso para mí? 
Y el punto desde el que se enuncia no es un lugar abstracto, sino un punto de vista, una mirada, una emoción, un afecto, un cuerpo. Esa subjetividad en diálogo con su tópico está tan alejada de la charla impresionista, como el ensayo lo está de la 'causerie'.54 Reivindica, contra el imaginario de objetividad, cierta subjetividad. Esa subjetividad no sólo se da en el punto de vista, en las instancias de la voz, sino que muchas veces el ensayista narra hechos biográficos dentro de sus ensayos:

Cuando el ensayista nos remite, a veces bruscamente, a veces escandalosamente a su propia vida, asistimos a un desenmascaramiento: en lugar de ocultarla (exigencia que el saber se impone), el discurso del ensayo muestra, como espectáculo y también como objeto de conocimiento, la subjetividad que lo enuncia. (2005: 243)

El ensayista, en tanto entidad construida en y por la escritura, es un personaje de su propio discurso. Montaigne, por ejemplo, creía en el hombre como un ser cambiante; y además, y lo repite a lo largo de sus ensayos, desconfiaba de su propia memoria, que creía escasa y falsaria. Así, la escritura de sus ensayos es también una forma de fijar en el momento presente, el de la búsqueda, el flujo de la identidad. Plasma en su exterioridad una imagen de sí que le permita conocerse al fijarla momentáneamente: "Para suplir su falta de memoria natural, Montaigne utiliza una memoria de papel, encargada de preservar su propia imagen del devenir del tiempo" (Navarro Reyes 164). Y en tanto Montaigne reconoce ser él mismo la materia de su libro, éste va convirtiéndose en el depositario de una imagen a través de sus distintas figuraciones; porque los distintos procesos de autofiguración tienen como fin engendrar una figura de autor. Si alguien puede hacerlo, el único que puede de alguna manera conocerse es uno mismo (o eso pensaba Montaigne), dado que la de uno es la única interioridad a la que se tiene acceso, sino directo, sí privilegiado. Así, el libro de Montaigne, a medida que se desarrolla, se convierte en un proyecto de autorretrato; un autorretrato escrito de la interioridad $^{55}$ de una persona, como un autorretrato pictórico plasma su apariencia física. Y dado que ese autorretrato se quiere fiel y no modélico, debe contener las complejidades e imperfecciones del original, así como los cambios que produce el devenir del sujeto. La coherencia interna del texto queda sacrificada a la fidelidad de la representación; es en este sentido que el ensayo se arroga su principio de contradicción, tanto como su principio de siempre inacabado, como su objeto mismo.

\footnotetext{
${ }^{54}$ Se trata, según Giordano, de una conversación heideggeriana, dado que interpela al objeto desde el interior de su lógica misma de experiencia (2005: 223).

${ }^{55}$ En el caso de Montaigne, no son sus acciones lo que describe, sino su yo, lo que considera su esencia.
} 
Estos principios mencionados diferencian al personaje de los ensayos del autobiográfico; se niega su coherencia evolutiva hacia un fin determinado. De lo que se deja constancia es de un tránsito, de un proceso, que al no abandonar la perspectiva del presente de la escritura, no puede unificar sus distintas manifestaciones en tanto evolución cronológica. El carácter de fragmento que preside los ensayos es así el más adecuado a este propósito, dado que procede por añadidos, reflejos éstos de estados diversos y momentáneos, y no por la subordinación de unos argumentos en otros o la coherencia evolutiva del personaje tradicional de la autobiografía o la novela. Lo que se lleva a la escritura no es el resultado organizado de un conocimiento, sino el propio conocerse, paralelo al proceso de su escritura; se ensaya un sujeto en el propio proceso de conocerse y, por tanto, no se dan conclusiones de ese conocimiento. La actividad de conocerse queda reflejada en el texto: "mediante el ensayo de sí, el sujeto conoce su propia forma y, a través de una escritura simultánea y coextensiva con esa experiencia, esa forma queda materializada en el texto. Autoconsciencia y expresión avanzan solidariamente" (Navarro Reyes 172).

El ensayista que así se conoce al escribirse, y entrega al lector ese proceso, toma forma en el conjunto de sus escritos. No se trata de una autobiografía ni unas memorias, dado que no siempre la propia peripecia es el tema central del ensayo ${ }^{56}$; $\sin$ embargo, trate de lo que trate, no se pretende una adecuación objetiva a los objetos descriptos sino una fidelidad subjetiva. Las palabras no quedan ya (tan) ligadas a su carácter representativo, en tanto verdaderas por la exactitud con que son correlato de los hechos del mundo, sino que su verdad reside en la adecuación al pensamiento del que son carne: "Porque en lo que digo la única certeza que garantizo es que se trata de aquello que en este momento tenía en mi pensamiento, pensamiento tumultuoso y vacilante. Hablo de todo a modo de charla, y de nada a modo de dictamen" (Montaigne 1542). El valor último del texto no es comprobable más que aceptando la fidelidad de la experiencia interior de la que surge; de ahí que debamos confiar en la 'buena fe' del ensayista, prestarle nuestra simpatía. Pero esta experiencia puede presentarse de modos distintos dentro del ensayo: en el caso de Bacon, si bien lo escrito está basado en la experiencia, se formula de manera abstracta, y son escasas las figuraciones del sujeto experimentante, al que conocemos indirectamente por lo que dice de las cosas; en el caso de Montaigne el yo concreto, sujeto de la experiencia, nos habla de sí y no sólo de

\footnotetext{
${ }^{56}$ Que puede serlo, como en el caso del ensayo autobiográfico.
} 
los tópicos de su discurso; conoce, y nos habla sobre lo que conoce, pero también se da a conocer, se figura directamente en tanto autor de su escritura. Porque, dado que el ensayista es el último fundamento de todo lo que se dice, su desaparición, su borramiento, sería negar la prueba (o escamotearla); es este carácter basal el que otorga tanta importancia a las autofiguraciones que el ensayista hace de sí para que lo conozcamos. No sólo saber que lo que se dice es fiel a una experiencia, sino saber de quién es esa experiencia y cuáles son las circunstancias (psicológicas, sociales, ideológicas, estéticas, etc.) de las que emerge. Saberlo da a quien lee elementos más complejos y certeros de apreciación del saber escéptico, relativo, con el que entra en diálogo; se le ofrece material para recomponer esa persona (aunque sea una máscara de palabras también) con la que conversa, las circunstancias que subyacen a la formación de sus juicios y gustos.

Los tópicos que el ensayo trata no ocurren, sino que le ocurren al ensayista. Y en tanto experiencia que tiene sentido, saber fenomenológico, sucede en un cuerpo. Se trata de no restar al conocimiento el cuerpo en el que se produce, su particularidad de emergencia en un ser determinado, un cuerpo histórico. Objeto y sujeto, subjetivizado aquél al internalizarse en éste, modificado éste por la emoción o el interés que aquél le despierta; el ensayista se construye en su escritura como escenario de un acontecer fenoménico (lectura, viaje, suceso, etc). Vive la cosa como acontecer, y está obligado a pensarse en tanto es en él donde la cosa acontece; al meditar sobre sí, hace algo propio con lo propio, ensayo un sujeto, una vida, una estética de la existencia. Ese yo en acto que se produce en la escritura, se basa en una filosofía de vida, una ideología de lo que el existir significa. Esto vale también para los escritos de tipo autobiográfico, donde el recorrido del personaje es una encarnación progresiva de esa filosofía, fin de un camino lineal. En el caso del ensayo, patente o escamoteada, esa filosofía, esa perspectiva que el ensayista impone, se entrega de manera fragmentaria, emerge de la interrelación del yo con su tópico. Es el lector quien debe ir componiendo la figura que los distintos ensayos, ya vueltos obra, contienen. No se sigue un camino ejemplar; se rastrean trazos, pistas, fisuras, de un yo fragmentario, espontáneo, consustancial a la escritura y el objeto que en ella se ensaya. En el ensayo no se definen conceptos; si se los utiliza, es a título personal; muchas afirmaciones no se argumentan; los temas se suceden, o se dejan de lado por largas digresiones; la definición, la prueba, y la unidad final y única se encuentran en el ensayista, y éste es una figura que el lector debe recomponer para poder calibrar lo que se predica, el modo de ensayar del que está participando. 


\subsection{Procesos de autofiguración en la obra Cyril Connolly}

Cyril Connolly tuvo una educación de privilegio y a la vez característica, la que la Inglaterra de principios del siglo pasado ofrecía a sus clases privilegiadas. Fue una joven y patente promesa de la literatura británica de entreguerras, y una promesa que nunca se cumplió; frustrada la ambición de la obra maestra con su primer novela, más o menos persuadido de no volver a intentarlo ${ }^{57}$, construyó su obra con las ruinas de su talento; ahí donde los personajes principales son el fracasado Connolly y sus libros y sus aficiones recurrentes. Es por eso que si algo llama la atención en los ensayos de Connolly, es la omnipresencia de su figura. Estas formas de autofiguración, de representarse literariamente ante sus pares y su público, serán constantes a través de todos sus escritos, y la creación de ese personaje es su obra más lograda: el perezoso, erudito, talentoso, francófilo, amante de los lémures, autoindulgente, gastrónomo, bibliófilo, viajero, dandy Cyril Connolly.

Estas características estilísticas y temáticas quedarán ya definidas desde su más temprana producción, y no harán más que retornar, con variaciones circunstanciales, en la espiral de sus escritos posteriores. A excepción de su primera y única novela publicada, The Rock Pool (1936) -que fue ya un fracaso para los altos estándares estéticos de la joven promesa Connolly-, todas sus demás obras, fragmentos, escritos, no es que sean fracasos (en algunos casos todo lo contrario), sino que se 'presentan' como fracasos, como los restos de un esplendente naufragio (no debemos olvidar el seudónimo y personaje tutelar de Palinuro, el timonel de Eneas, que utiliza en una de sus obras más aclamadas, La tumba inquieta); son desde su misma concepción las muestras de un fracaso previo, las razones de una imposibilidad: la de crear una obra maestra, y la de encarnar en una realidad histórica, cotidiana, al artista ideal capaz de concebirla y ejecutarla, con sus hábitos y destrezas. Lo que perdura entonces, lo que sorprende, no es su fracaso, o el fracaso -muchísimo más ordinario que el éxito- sino el cuidado, el esfuerzo, el énfasis que se pone en analizarlo, retratarlo, hacerlo arte. Es lo mismo que sorprende en El Crack-Up, de Scott Fitzgerald, editado pocos años después de su muerte por su amigo Edmund Wilson, por curiosa coincidencia, en el mismo año de 1945 en que Connolly publica dos de sus obras más reputadas, La tumba inquieta y

\footnotetext{
57 “Muchos años después, Connolly justificaría su incapacidad para la ficción alegando que no tenía ningún aprecio por el género humano y que cada vez que intentaba narrar algo con seriedad se le escapaba la risa" (Andreu Jaume en Connolly 2005: 13).
} 
The Condemned Playground, que representan tanto el fin de una breve primera etapa de su producción como el punto álgido de sus capacidades. Porque si bien Connolly, implacable, es consciente desde los inicios de su carrera de la imposibilidad de encarnar su ideal, por lo menos al principio era ambicioso; las obras de esta primera etapa son muestras muy logradas de un ambicioso fracaso.

Es por eso que en adelante me voy a ocupar, dejando de lado su única obra de ficción, de las obras de esta que considero su primera y mejor etapa, donde publica los libros por los que se lo recuerda y aún se lo revisita casi un siglo después: Enemigos de la promesa (1938), La tumba inquieta (1945) y The Condemned Playground (1945). Los dos primeros fueron concebidos y escritos como volumen; se trata de textos ensayísticos de extensión considerable y que presentan unidad de ejecución y propósito, aunque en ciertos casos no sea aparente; el tercer volumen es una recopilación de ensayos previamente aparecidos en revistas y diarios, con variedad de temáticas y estilos, que van desde 1927 a 1944. Dejo para el capítulo siguiente el tratamiento pormenorizado de las que podemos llamar las dos obras mayores de Cyril Connolly para ocuparme ahora de algunos ensayos de esta primera recopilación, con el fin de analizar cómo se representa el autor ya en su primera escritura.

The Condemned Playground contiene desde el primer ensayo publicado por Connolly ("Distress of Plenty", 1927, sobre la obra de Sterne), que le encargara Desmond MacCarthy para el New Statesman, hasta ensayos contemporáneos a la escritura de sus obras mayores; son escritos por tanto que van de los veinticuatro a los cuarenta y un años del autor. De temáticas y estilos muy variados, los escritos de este volumen, como adelanté, contienen no sólo el germen de la obra posterior de Connolly sino, en algunos, el culmen de ciertas particularidades de su talento, como es el caso de las sátiras de autores contemporáneos ("Where Angels Fears to Tread", "Mr. Mossbross takes the Class", "Told in Gath", etc.); hay además ensayos de viaje, reflexiones sobre el estado de la literatura y la crítica, fragmentos de diarios, análisis y reseñas de autores y libros, etc. Ya me ocupé en el capítulo anterior, y lo voy a hacer en los capítulos siguientes, de la faceta de Connolly como hombre de letras que, en tanto ensayista, se ocupa de las letras específicamente, y de analizar cómo interviene su experiencia en esa lectura escrita. Es por eso que de entre la variedad de ensayos que componen este libro, selecciono tres que son representativos de otros tópicos recurrentes en la obra de Connolly y que permitirán el análisis de distintos procesos de autofiguración. 
El primero de ellos, "England not my England", reúne fragmentos en forma de diario que Connolly publicó de manera conjunta; el segundo, "Conversations in Berlin”, es la remembranza de un viaje en compañía de amigos y de las conversaciones que mantuvieron; y el tercero, "Noventa años reseñando novelas" ("Ninety Years of Novel-Reviewing”), es un análisis, a la vez que una sátira, sobre la crítica y la reseña de libros. Estos tres ensayos, además de pertenecer al mismo volumen, pertenecen a la misma época, como nos dice el mismo Connolly en la "Introduction" de 1944: "I have included in this book some of the earliest things I wrote [...] "England not my England", [...] "Ninety Years of Novel-Reviewing" and "Conversations in Berlin", were all written between the age of twenty-three and twenty five, and seem to me as good as anything I have managed since" (1946: vii); por tanto, los considero representativos, tanto en procesos y temas como en calidad, de su obra posterior, y permiten apreciar la que fuera su irrupción en el campo literario de los años veinte. Si bien es, por supuesto, de escritura posterior a los ensayos del libro, quisiera detenerme primeramente en la mencionada introducción, dado que en ella Connolly hace un repaso, pero también una valoración de la crítica y de 'su' crítica, que será de utilidad en tanto revela una creencia sobre su tarea, o la poética que subyace a ésta.

El libro significa para Connolly la escena literaria de 1930, "a period of ebullience, mediocrity, frivolity and talent during which I wrote most of these essays and my first two books" (1946: vi). Dado que la introducción es una mirada retrospectiva, y el libro es una recopilación, se trata de una selección que implica el olvido, y en su caso algo de nostalgia. "Art is man's noblest attempt to preserve Imagination from Time” (1946: vi), asegura; sin embargo, muchas palabras, frases y hasta ideas caen luego en el olvido. Esta sensación de evanescencia ha estado siempre con él como crítico, nos dice. Siente que libra una batalla de retaguardia, dado que cada generación vuelve a descubrir el valor de sus clásicos, y las generaciones nunca son las mismas, y la suya, generación de dos guerras, prefiere nuevos y violentos estímulos -la prensa, la radio, el cine- a "the slow permeation of the personality by great literature" (1946: vi). Una vez introducido el tiempo, histórico y existencial, y la finalidad a que estos ensayos responden, Connolly nos representa sus inicios en la crítica:

Like most of our critics I drifted into the profession through a lack of moral stamina: I wanted to be a poet, and to revive the epic; I wanted to write a novel about archaic Greece -but my epic and my novel fell so short of the standards which my reading had set me that I despaired of them and, despairing, slipped into 
the interim habit of writing short-term articles about books. The habit grew and conquered: many years later, and almost too late, I set out to conquer it. That is how most of our critics are formed. Not I despise criticism: I wish only that I had been a better critic [...]. (1946: vi).

Pero ojalá hubiera sido un mejor crítico, nos dice, y no hubiera escrito, porque se lo pidieron, sobre tantos malos libros. Los méritos que pueda tener son simplemente algo práctico y terrenal: se mantiene muy cerca del texto; no es un águila que divisa desde su altísimo vuelo sino una que oscila por lo bajo, cazando por el olor, y con la nariz pegada al suelo. No está seguro de que un crítico deba tener opiniones. La experiencia desarrolla en el crítico un instinto, que, como la horquilla del rabdomante, lo hace vibrar cuando está cerca del tesoro ${ }^{58}$. La explicación y el análisis son posteriores.

Sobre el objeto de sus preferencias, que en varios lugares de su obra trata de dejar en claro, comenta que disfruta de escribir, en primer lugar, sobre los grandes, solitarios y formales artistas que, disconformes con su época, la desprecian ("who spit in the eye of their century", 1946: vii); después de ellos, sobre los feroces y talentosos jóvenes escritores que encuentran un final prematuro gracias a la pasión; y, por último, sobre esos sabios epicúreos que combinan el gusto con un chismorreo de buen tono sobre el mundo, y cuyos elegantes libros son apenas las sombras de una íntima comunión con sus amigos y con la naturaleza. A veces no desdeñó burlarse de los pomposos y pretenciosos, los best-seller de segunda línea cuya palabra parecía ley en los años treinta; un período decadente donde el autor se vio decaer con él, "or perhaps, a typical Rimbaud who couldn't write"; se sintió en rebelión consigo mismo y con su época (1946: vii - viii). Al hacer un repaso de los artículos que incluyó en el libro, con su respectiva justificación, nos dice que algunos presentan un contraste de actitudes que los artistas adoptaron en esos años: la de la torre de marfil flaubertiana o la del compromiso político; así, al repasar un "Comment” que escribió para su revista Horizon concluye que la propaganda, los eslóganes y las arengas patrióticas de aquellos años han pasado su factura, y cada vez que encuentra en el texto un 'nosotros' es siempre el preludio de una serie de clichés. Una opinión que, llevada a la crítica, y con otros matices, repetirá en otros escritos que más adelante voy a analizar.

\footnotetext{
${ }^{58}$ Hago notar aquí el persistente uso de la comparación, que resalté en el capítulo anterior.
} 


\section{"England not my England" (1929)}

Este ensayo tiene como tópico, entre otros (opiniones sobre la literatura, el otoño, la vida misma), una historia de desamor entre el autor e Inglaterra. Consta de un breve prólogo y lo demás son extractos (¿reelaboraciones?) seleccionados del diario personal del autor entre 1927 y 1929. Queda seducido por París, y siempre está esperando escapar. Las cosas podrían haber sido distintas si el país hubiera sido más generoso con su dinero, el autor más industrioso con su pluma y ambos más pacientes y comprensivos. El autor tenía veintitrés años, y esto es una selección de desamores; por lo demás "like most lovers, the author appears fractious, embittered, egostistical, and not always inclined to be sincere" (1946: 196). Cada entrada, nos dice, parece el eco de la queja de Marcial: "non tecum possum vivere, nec sine te" (No puedo vivir contigo, ni $\sin \mathrm{ti)}$.

Ya en la segunda entrada, de julio de 1927, introduce uno de los temas principales, su relación ambivalente y culpable con la escritura: "I have no ambition, but will a horror of being stationary, a panic fear of keeping still, make up for it?" (1946: 197). Unos días más tarde, habla de ese sentimiento con el crítico Desmond MacCarthy, que lo había reclutado recientemente para el New Statesman; le dice que a su edad él era igualmente ocioso, y que eso lo hacía sentir mal. (Consuelo que Connolly, menos complaciente, debería haber evaluado con pericia crítica: MacCarthy fue acusado por sus contemporáneos de Bloomsbury, y por la misma posteridad, de haber malgastado un enorme talento a causa de la indolencia; mismo caso de Connolly).

Depresión en Londres. Mejor no haber nacido, y habiéndolo hecho, sería mejor vivir en Cádiz. Luego, se siente algo feliz cerca del mar, en verano, y fuera de Inglaterra. Resuelve vivir más y más en el presente, cultivando la intensidad y la inconstancia en las relaciones personales, cosa de sentirse libre de las uniones que lo atan al pasado; estudiar la vida, no la muerte, el presente, no el pasado, la actualidad, no la literatura; sólo dando todo al presente él le dará lo mejor de sí; vivir en el presente es la mejor forma de vida, porque es la única manera de crear un pasado valioso: "Life has no moral, and the moral of art is that life is worth while without one" (1946: 198).

Cumple los veinticuatro, y se siente peligrosamente contento. Por una vez se siente con ambiciones, deseante, y cree en sus chances de fama. Mientras escribe esto, encuentra un pasaje del diario de Logan Pearsall Smith: "Venice. Church at twilight. Candles. People die. [...] I too shall die [...]. Let me treasure the right things, see this world brighter for the frame of death" (1946: 199). La misma súplica, el mismo interés 
que el suyo. El llanto retórico de toda juventud a toda vida. Caras muertas de Londres, amor por París y España. Y una de sus clásicas listas: para obtener antes de los veinticinco: mil libras al año, un libro publicado, una amante española, algo de fama, más amigos, los rudimentos del alemán, y una visita a Cádiz.

Disfruta el momento y no trabaja, cada vez se le hace más difícil leer o escribir. Se recuesta en el puro hedonismo material; los sentidos alimentan la mente como ninguna otra cosa puede hacerlo: sol, aire, una cerveza antes de la caminata. "Life alone is worthy of being worshipped, and with the highest blend one can bring to it of scholarship and vitality” (1946: 200). Londres es demasiado peligrosa; debe ir a Cádiz para trabajar.

Nueva depresión, física y literaria: “Literature is a dead form” (1946: 200). Evita a la gente de letras, se dice, no hacen más que dar vueltas y vueltas. Nuevo esquema de vida: hacer dinero, largos viajes, dejar la escritura. Tomar notas y fijar momentos, pero tomarse el trabajo de ponerlos en orden recién cuando llegue la vejez. El mismo mes, dos semanas más tarde: "Damn life, damn love, damn literature! In other words, damn journalism! [...] Too soft for journalism, too rough for literature" (1946: 200). Debe dejar el periodismo; pero continúa con pavor por la literatura. Debe abandonar Londres: está americanizada pero sin la vitalidad de Estados Unidos; su gente está empapada de demasiada tradición y cultura, y no lo suficientemente consciente de ello para crear algo nuevo por fuera. Pasa las vacaciones en España, a su regreso: "Unpleasant sense, not only of being practically just where I was this time last year, but of being practically just where I was the year before. As homeless, futureless, hopeless, and unestablished as ever" (1946: 202).

El deseo de París: los cafés, las luces, los interiores acogedores, los borrachos, los artistas, los bulevares, la sensación de libertad y rebelión. Londres es sólo para los ricos, o para los esnobs, los artistas de borgoña y golf; sus bohemios deben ser acicalados. "The more one sees of life the more one is aware how hopeless it is without art to give it meaning” (1946: 204). Balance del año: leyó y escribió muy poco, sin embargo sintió un aumento de confianza en sí mismo y su aptitud para la vida. Deterioro en su nobleza, caída física, emocional y moral, rebelión estética. Otra vez nueva resolución: "To be altogether more advanced and intelligent, to have more friendships and fewer affairs, to write and read more than I eat and drink, to revisit Paris and write a prize novel” (1946: 205). En esa Londres sin intelligentsia, sombría, 
rica, de caballeros estilo s. XVIII, maderas oscuras y chalecos amarillos, siente que "I exist only to celebrate my sense of guilt" (1946: 210), nos dice.

\section{“Conversations in Berlin” (1930)}

Este ensayo se estructura en forma de memoria; Connolly recuerda algunas conversaciones que mantuvo junto a dos amigos (H y Raymond) en Berlín. En principio recuerdan su juventud; la juventud es un tiempo de desventuras, se dicen, y sólo debe ser valorada y disfrutada como tal: la larga lista de oportunidades perdidas es al fin más rica y significativa en su torpeza que la avara filosofía del "never-miss-a-moment" que la reemplaza en la juventud tardía y la madurez (1946: 211). Otra noche se preguntan si existe algún libro que pueda ser erigido como test de inteligencia, uno que trace una línea definitiva y divisoria. Connolly sugiere a Proust, porque leerlo todo requiere algo más que cultura, y uno debe remover de su mente muchas ideas de segunda mano: "Proust's real importance was that he taught one how best dramatically to interpret one's own life” (1946: 211). R sugiere Adolphe, Clarissa, y los clásicos franceses. H opina que un grupo importante de gente lista y estúpida leyó cada línea de Proust, y siguió siendo tan estúpida como antes; seguramente también leyeron a Joyce. Ningún tipo de cultura puede servir de test a ningún tipo de inteligencia. Acuerdan. Entonces pasan a tratar de analizar la inteligencia.

Connolly define la inteligencia como: "criticism of life"; la capacidad de apartarse de la vida y juzgarla, como la de apartarse de uno mismo para analizarse, que no tienen los animales; la capacidad de relatar la propia experiencia a otras personas, y generalizar a partir de lo particular verdades sobre el vivir. $\mathrm{R}$ le dice que parece estar en contra de la inteligencia, o del intelecto, por lo menos. Y Connolly le responde: "I said I was, for intellectual pride had always a deshumanizing effect. One appreciated one's knowledge of a subject rather than the subject itself, one lost the capacity for worship or for seeing a thing or a person apart from our sense of power over them. I preferred the imagination" (1946: 212). Sus amigos acuerdan que la inteligencia perfecta es una mente absolutamente libre, dotada de infinita curiosidad, y por lo tanto ansiosa y capaz de captar e iluminar cualquier tema no técnicamente específico. Connolly reconoce que es eso lo que no tiene; gusta de lo oscuro y practica la falta de curiosidad. Odia a las personas muy informadas con fluidos conocimientos generales y una viva curiosidad por los problemas actuales. Él no está interesado en la actualidad, sólo en las cosas del 
presente que sirven a su imaginación e, incluso, ve en todas las artes un estanque de narciso (1946: 212).

Sin embargo, $\mathrm{H}$ le dice que hay una veta de erudito en él, en su naturaleza y en su admirar la erudición. Connolly cree que es cierto; y le responde: "It's not the scholar in me that is incurious, [...] only the Celt" (1946: 213). Cree tener un buen intelecto y una educación clásica, pero debajo yace el ensueño, la falta de curiosidad y la melancolía celta. Vegeta y da vueltas por horas sobre cosas del pasado, sobre conversaciones y características de la gente, como en un ensueño diurno. El propietario de la pensión recibe una llamada de larga distancia, de Múnich, y los tres amigos reflexionan sobre su contenido a partir de las caras del hombre. Este tipo de observación es el verdadero talento del novelista, dice R. Connolly responde que es la capacidad de poner por escrito lo observado; y cree que hay que escribir sólo sobre lo que a uno le interesa, y dejar afuera, aun si eso afecta a la trama, todo lo que a uno lo aburre, y después seguir, sacando lo innecesario. Revisar es sacar, no poner (1946: 214).

Recordando esos días, esas tardes, Connolly siente que la verdadera felicidad tiene más de angustia que de éxtasis; que esos momentos no fueron de alegría sino de perfecta civilización: un ejemplo de la imbricación europea, de los muchos y discretos estratos del viejo mundo, de la fuerza del norte en el atardecer de ese pueblo, y del poder de las ideas (1946: 215).

"Noventa años reseñando novelas" ("Ninety Years of Novel-Reviewing”) (1929)

Este es el primer ensayo de Connolly sobre un tema al que dedicará varios: la crítica periodística. Como en los demás casos, que más adelante voy a tratar, su mirada es irónica y, si no desprecio, demuestra tensión. De baja por 'invalidez' desde febrero (el ensayo se publica en agosto), aún recuerda sus últimos esfuerzos en la selva. Porque el ensayo comienza así, con contundencia:

La crítica de novelas es la tumba del periodismo; es el equivalente, en el mundo de las letras, a construir puentes en algún clima tropical imposible. Es un trabajo duro, poco saludable y mal pagado, y por cada palmo de espesa vegetación que se logra desbrozar con arduo trabajo, la selva avanza el doble durante la noche. (2005:611)

A los treinta años un crítico de novelas ya es viejo, y la jubilación anticipada se vuelve inevitable; sus escritos posteriores, sin embargo, estarán viciados de una amarga y malhumorada brillantez que sólo se aprende en esa escuela. 
"Una de las visiones más desagradables en la selva es la del crítico que acaba convertido en indígena. En lugar de luchar contra la vegetación, sucumbe a ella" (2005: 612), y va de flor en flor prodigando alabanzas. Por otro lado, está el novato, recién llegado de la universidad, con la determinación, "por encima de todo, de ser justo, de juzgar cada libro por sus méritos, de no dejarse extraviar por los melindres y finuras de la escritura, ni por la tentación de destrozar un libro en la reseña, sino básicamente de intentar ayudar al autor al mismo tiempo que se aconseja al lector" (2005: 612). Lo importante es no olvidar nunca el nivel de exigencia que uno se marca. A continuación sigue un diálogo ficcional, que el narrador dice recordar, entre estos dos personajes, a los que llama Novato (Tenderfoot) y Untuoso (Goo-Goo) sobre Enredaderas o trepadoras (Goosegrass or Cleavers) la primera novela de la señorita Culodeviolín (Miss Bumfiddle). Es un vaivén burlesco donde se parodian las jergas y actitudes de estos críticos arquetípicos; como luego también, mediante un supuesto extracto de la novela, la de ciertos escritores de la época.

Al estar retirado, se olvida fácil la tensión nerviosa, la náusea y "la cínica desesperanza con la que nos afanábamos por enfriar el entusiasmo de los infatigables autores" (2005: 616), y no puede sentir, si no felicidad, pesar y ternura por haberse librado de sus libros. "[...] las tempranas expectativas que uno tenía de descubrir a un nuevo autor son quizá un placer menos gozoso que las esperanzas posteriores de desacreditar a un viejo escritor" (2005: 616-617), así es como cambian las cosas con el tiempo. Y nos dice que el problema no sería tanto que las novelas inglesas fueran malas, sino que no cumplen con el requisito de ser legibles. Cualquier novela norteamericana de segunda fila atrapa al lector; si uno se da cuenta de que se trata de un libro menor, por lo menos disfrutó mientras lo leía.

Hay una justicia poética que vuelve trágica la profesión de crítico: por todas las novelas que frustra, la novela lo acabará frustrando; la selva lo reclama. Sin embargo, se trata de una profesión que debe existir, y el joven Connolly, por tanto, se permite dar algunos consejos a quienes se vean forzados -porque nadie puede hacerlo voluntariamente, afirma- a practicarla (me permito citarlo in extenso):

En primer lugar, nunca elogies; los elogios quedan anticuados. Al hacer la crítica de un libro que te gusta, escribe para el autor; al hacer la crítica de cualquier otro, escribe para el público. Lee los libros que reseñas, pero no ojees más de una página para decidir si merecen ser reseñados. Jamás toques novelas escritas por tus amigos. Recuerda que el objetivo del crítico es vengarse del creador, y su método debe estar en función de si el libro es bueno o malo, si debe condenarlo o debe quedarse quieto $\mathrm{y}$ dejar que pase al olvido. Todo buen crítico tiene un tema predilecto. Se 
especializa sobre ese tema sobre el que ha sido incapaz de escribir un libro y su meta es comprobar que ninguna otra persona lo logra. [...] Cuando ha dejado fuera de combate a un número suficiente, se convierte en una autoridad, que es más de lo que ellos lograrán. (2005: 618)

Sin embargo, el retiro planteado en el ensayo parece no ser definitivo -como sabemos que no fue-. En su última página se pregunta si realmente debe un crítico jubilarse temprano, si de verdad está acabado a los veinticinco, si puede volver. En el hotel de un pueblito francés junto al mar, recibe una carta desde Nueva York que le devuelve la esperanza; alguien le pregunta cuándo le dirá al público que las tres últimas novelas de Compton Mackenzie atraparon el estilo de la prosa y la actitud ante la vida de Congreve: “¿Cuándo? -suspiré, y tenía lágrimas en los ojos-, ¿cuándo lo haré?” (2005: 619).

\subsection{Una figura de autor}

Estos ensayos que brevemente presenté, aunque tempranos, y más allá de sus diferencias, pueden considerarse una muestra típica y ejemplar de algunos temas recurrentes en la producción de Connolly: el escritor fracasado, la promesa incumplida, el proyecto aplazado. Y lo que resulta extraño es que Connolly decide presentarse, figurarse a sí mismo de ese modo desde el momento inicial de su irrupción en el campo literario; no se trata de que el campo mismo, en su proyección temporal y selectiva, haya decretado a Connolly un autor menor, o fracasado; ni es que esa sentencia, en la pluma de críticos posteriores, haya sido juzgada como cierta. Connolly construye en su escritura misma el acontecer de un fracaso; un fracaso, como trataré de establecer, que al fin tuvo bastante éxito, ejemplar.

El debate que toma forma en estos textos no deja de ser un tópico literario: se trata del "escritor malogrado, prisionero de sus circunstancias, que fracasa por carecer de libertad para consagrarse a su obra" (Gramuglio 39); sin embargo, como siempre en la literatura, estos tópicos sufren tanto las reformulaciones estilísticas de cada autor particular como las variaciones propias de la historia y el campo literario donde juegan y luchan. En el caso de Connolly no se trata del 'genio incomprendido', el artista solitario que la sociedad rechaza, "those great, lonely, formal artists who spit in the eye of their century" (Connolly 1946: vii), a los que él mismo respetó y a los que dedica sus preferencias. Tampoco es que haya estado abrumado y preso de las circunstancias como para carecer del tiempo y el descanso necesarios que las obras que quería escribir le 
parece que merecen (aunque él también deseara y creía necesarias para el artista esas mil libras al año, si provenientes de rentas mejor, que pregonara Virginia Woolf). Su caso es otro: sus obras fueron bien recibidas: The Rock Pool, su proyecto mayor en la ficción, no fue un éxito, pero se trata de una primera novela, que aún puede leerse y se reedita y traduce a veces; podría haber continuado en el campo de la ficción sin mayores problemas; Enemigos de la promesa y La tumba inquieta, sus dos esfuerzos mayores en el campo de la escritura, fueron celebrados desde su publicación y se trata de verdaderos clásicos; sus ensayos fueron leídos, respetados y odiados, y el mismo Connolly fue considerado hasta su muerte una autoridad.

¿Entonces, cuál es el problema? El problema reside más en el conflicto subjetivo del autor que en la inadecuación al campo; o, más bien, las expectativas que él se formó de sí mismo como autor (y que hizo suyas del campo literario del momento), lo que él pensó que debía hacerse, no coincidió con lo que hacía; por temperamento -o eso es lo que nos presenta- estaba incapacitado, o no del todo dotado, para realizar el tipo de obra que el campo más le enseñó a valorar. Hizo obra, y obra exitosa, pero no la obra que él deseó, la impoluta obra maestra, no intentada, intacta, prometida, que subyace a su obra restante.

Fue un hombre de letras exitoso, pero no un 'autor' exitoso; no fue el autor que dijo querer, y no le satisfizo un éxito que consideró vicario. No supo, o no se resignó a, contentarse con cumplir otras de las funciones que el campo literario ofrece; $y$, en tanto potencial autor, no supo, dentro de la ficción, aunar sus talentos a su carácter para crear una obra original, disruptiva dentro de las expectativas del campo; una obra que hoy es aceptada, típica, y en boga: ciertas escrituras del yo, mezcla de ensayo y fícción, como las de Julien Gracq, W.G. Sebald, Jorge Luis Borges, Enrique Vila-Matas, Ricardo Piglia, por mencionar algunos. Quiso ser un poeta, o un novelista, un artista de la escritura como Flaubert, como Joyce o Eliot, y sintió que no podía. Y eso se nota en su obra, esa gran ambición, esa intuición del arte; una potencialidad autoral de la que sus escritos parecen, o se presentan como, meros vestigios.

El conflicto principal, según el mismo Connolly lo presenta, es que tuvo, por formación, el hábito de la literatura, pero no tuvo, por temperamento, el hábito del arte. Y siempre culpó de esto a su sangre celta, nostálgica, ensoñada, perezosa, y a su educación romántica. Es por eso que, como destaqué en su diario, en la obra de Connolly se presentan con insistencia las resoluciones, los proyectos. Proyecta lo que va a hacer, sabe cómo hacerlo, y por momentos cree, y le hacen creer, que tiene el talento 
para hacerlo; pero no lo hace (y en este sentido, el diario, en tanto documento de un acontecer presente, permite asistir al proyecto y a su fracaso, al optimismo de la resolución y al pesimismo de la voluntad). No actúa, no pasa a la acción, y, cuando lo hace, es para expresar su inactividad; para actuar su inactividad.

Este poner en acto una inactividad es, al fin, una escritura sobre la imposibilidad de escribir, escribir sobre no-escribir. Connolly entonces, en tanto ensayista, como lo adelanté, es un espectador: un espectador del fin del mundo humanista, de la guerra, de la literatura, de su propio fracaso. Pero no se limita a traducir lo que ve, se representa espectando; como en una mise en abyme actúa de espectador, representa al espectador (ensayista) que actúa al espectador (Connolly de papel) de algo; a veces de sí mismo. A lo que asistimos en estos ensayos por tanto es a la mirada de Connolly sobre Connolly fracasando como autor; Connolly que escribe sobre Connolly que no escribe.

Este no escribir tiene (además del que pudiera ser el fracaso dentro de la literatura misma) una de sus causas en el clásico agón arte contra vida. El ocio lo hace sentir culpable, dado que su fantasma nunca dejará de ser el de autor; no trabajar le genera la depresión y el horror de estar estancado, en el mismo lugar año tras año -cosa que la lectura del diario permite comprobar-. La tensión, rasgo típico de su obra, que en este caso encarna en, por un lado, la celebración de los sentidos y los viajes, que lo hacen sentir alegría y esperanza, su lado típicamente epicúreo; por otro, en la necesidad de la obra, de realizarse mediante la práctica del arte, los hábitos estoicos del artista. Su inclinación constante hacia el cautivante mundo de los sentidos lo hace sentir en deuda con su fantasma de autor, solitario, entregado a la forma; entre la realidad y el fantasma, la culpa: "I exist only to celebrate my sense of guilt" (1946: 210).

Entonces Connolly celebra tanto un lado como el otro, según el humor, sin decidirse por ninguno de esos opuestos, sin encontrar tampoco una síntesis, ni una tensión más o menos estable o productiva. En una entrada nos dice que disfruta del presente, sin leer ni escribir, y que los sentidos alimentan la mente como la literatura no podría hacerlo; resuelve dejar la escritura (no emprendida, sólo fantaseada) proyectando escribir en la vejez a partir de los apuntes de su aventura (1946: 200); para luego afirmar en otras que debería haber sido más industrioso; resuelve viajar a París o a Cádiz para poder escribir, publicar una novela, debe escribir y leer más de lo que come y bebe, porque la vida carece en sí de sentido sin el auxilio del arte (1946: 204). Consciente, en algún momento de relectura (¿selección, reelaboración?) de estas entradas, de la tensión que muestran, intenta una síntesis imaginaria: "Life alone is worthy of being 
worshipped, and with the highest blend one can bring to it of scholarship and vitality" (1946: 200). Cómo mezclar en su justa medida erudición y vitalidad, arte y aventura, trabajo y ocio; esa es la inquisición, el enigma que Connolly se propone resolver una y otra vez en sus ensayos: cómo debe vivir el artista para crear su obra, cuáles son los hábitos y las prácticas propias del arte, y cuáles de ellos son sus enemigos. Uno de los logros más importantes de su obra es que supo encontrarlos y analizarlos, tanto amigos como enemigos; pero personalmente siempre se queja de no haber podido adquirir unos por no haber podido evitar los otros. En este sentido se trata de un fracaso exitoso, ejemplar. Sabe cómo hay que hacer para escribir un libro que dure, una obra maestra, y cuáles son los enemigos de esa ejecución; pero si su capacidad crítica, su clarividencia, le permitieron identificarlos y analizarlos, su temperamento no le permitió evitarlos. Y dedicó lo mejor de su talento, de su arte verbal, a reconstruir, a representar ese fracaso; dejando entrever en su ejecución los vestigios, los fragmentos de la obra maestra que pudiera haber escrito de no haber llevado la pereza en la sangre. Ensayó con espaciada pero obsesiva entrega una escritura sobre otra escritura que no existe, que es sólo potencia de ese autor dotado, y construyó su figura de autor, desde un inicio, sobre esa incapacidad: la de alguien que iba a escribir algo tan perfecto -y esperaban que lo hiciera- que era imposible de escribir; alguien que se entrega al ensayo periodístico ante el horror paralizante de la belleza literaria.

En "Conversations in Berlin" vuelve a tratarse este compromiso tenso con la 'vida'. Al recordar la juventud, Connolly dice que su larga lista de oportunidades perdidas es más valiosa que el “never-miss-a-moment” de la edad madura. El problema, la culpa de Connolly, es que seguirá, nostálgico, perdiendo oportunidades, pasando el tiempo, como un joven, ya estando en la edad adulta: oportunidades perdidas, promesas truncas. Arrastrará la perduración de esa situación juvenil, que quedó anclada en su Edad de Oro de los sucesos de Eton. En Eton y en Oxford fue donde adquirió la educación clásica y exquisita (en la que me voy a detener cuando trate la tercera parte de Enemigos de la promesa) que le inculcó los valores estéticos de base que conformarán sus gustos y juicios sobre el arte. Los clásicos latinos, en especial Tibulo y Petronio, los clásicos y modernos de su propia lengua, y los escritores franceses, con Flaubert en el s. XIX y Proust en el XX como estandartes. Justamente de éste conversan los amigos en Berlín -cabe recordar que el ensayo se publicó en 1930, y que la conversación 'sucedió' años antes, y por tanto es estrictamente contemporánea a la publicación de los últimos libros de Proust-. Connolly propone a Proust (a su libro) 
como medida de un test de inteligencia. Más allá de Proust -y lo que esta preferencia muestra- o de una charla sobre la inteligencia, lo que subyace es la búsqueda de un valor literario cierto, de un patrón artístico indiscutible que, de alguna manera, pudiera tomarse como la literatura en sí.

Como no existe un acuerdo entre los amigos -ni existirá, más allá de cierto consenso, dado que ese absoluto literario es un imaginario- comienzan a cuestionarse qué es entonces la inteligencia. Connolly habla de ella fríamente: "criticism of life”; se trata de la capacidad, solamente humana, de apartarse de la vida, de uno mismo, de un objeto, para poder analizarlo; la capacidad de generalizar (abstraer) a partir de experiencias particulares. Cuando su amigo le dice que no parece tener en mucho a la inteligencia, Connolly le responde que es cierto; ve en el orgullo intelectual algo deshumanizador, que es parte de ese mismo alejamiento: se termina apreciando más el saber sobre la cosa que la cosa misma; se pasa a ser espectador en vez de protagonista, un crítico y no un actor; es por esto que prefiere la imaginación. Dice no soportar a la gente informada y preocupada por la actualidad; por su parte, le interesa de lo actual lo que despierta su imaginación y no puede dejar de ver, en las artes, más que un estanque de Narciso. Entonces, por un lado, dice rechazar la inteligencia, la capacidad de análisis y generalización, a partir del conocimiento de un objeto del que se ha tomado distancia; sus amigos afirman que "the perfect intelligence was an absolutely free mind" (1946: 212). Por otro, se decanta por la imaginación, la solitaria y caprichosa imaginación que, a partir de un suceso cualquiera, puede metamorfosearse libremente, sin razón ni límite. Y, además, en el arte -ejercicio de imaginación si los hay- no deja, o no puede dejar, de buscarse a sí mismo.

Pareciera darse aquí una verdadera toma de posición, una opción de una por sobre otra de forma clara y determinante: Connolly prefiere las cualidades del autor ficcional, del artista, a las del crítico. Es por esto que la sencilla decisión es un poco más enrevesada de lo que parece, porque estamos leyendo el ensayo de un crítico que quisiera ser escritor, alguien que se ve 'forzado' a trabajar bajo un paradigma cuando quisiera ser juzgado bajo otro. Y esto se vuelve más complejo aún cuando la toma de partido es menos clara de lo que parece: Connolly es un erudito, le dice uno de sus amigos, que admira la erudición y se comporta en consecuencia; fue educado de 'la mejor manera' para ser un intelectual; él lo reconoce, y afirma: “It's not the scholar in me that is incurious, [...] only the Celt" (1946: 213). Lo que en un primer momento pareció que estaba separado, ahora está mezclado, en el mismo autor, produciendo la 
tensión que vengo analizando: si antes la vimos enfrentar arte contra vida, ahora enfrenta imaginación contra razón, con la misma imposibilidad de síntesis.

En consecuencia, en su imaginario, Connolly siempre está más cerca del artista que del crítico, lo cual es patente por las facultades que valora, la imaginación y el solipsismo, por sobre la razón y la "deshumanización", el desapego. Pero se trata siempre de un imaginario, dado que en realidad es un erudito y actúa como tal. El problema es que casi es lo que no quisiera, y no es lo que cree que quisiera. Al hablar con sus amigos sobre el novelista dice que su verdadero talento es el de la observación, cierta observación, si no deductiva, con algo de imaginación; poner por escrito lo observado, y de aquello observado, e imaginado, sólo lo que atrae el interés del autor, más allá de las exigencias de la obra; la conciencia formal viene más tarde, cuando se aplica un saber de las formas, cierto saber literario, en la revisión, donde se saca lo innecesario. Una vez más, busca la solución a su dilema, y se imagina un artista que tuviera para con su trabajo las mismas facilidades que como hedonista tiene para abandonarse a los sentidos; el trabajo por puro placer, sin molestias ni exigencias; el trabajo como abandono y no como producción. Cuando escribe estas máximas no habla desde la experiencia, sino desde la fantasía; indaga otra vez cómo ser un escritor, cómo puede él ser un escritor -se habla a sí mismo, buscando condiciones de posibilidad para la obra y su propia realización mediante ella-.

Otra de las principales causas de la no-escritura, aunque en estrecha relación con las anteriores, está explícita en las palabras de Connolly en la "Introduction", que me permití citar en toda su extensión: quiso él ser un poeta y un novelista, pero lo que pudo escribir estaba por debajo de los estándares que había adquirido con sus lecturas; desesperanzado, cayó en el hábito eventual de escribir artículos breves sobre libros; con los años ese hábito se apoderó de su escritura y él era un crítico. El crítico como escritor fracasado: Connolly nunca oculta esta capitulación, y él cree que la mayoría de los críticos se forman de esta manera. Lo que no quita que se pueda ser un excelente crítico, y que se debe serlo si es eso lo que se hace.

En fecha tan temprana como 1929 ya Connolly quiso abandonar la crítica, nos dice en "Noventa años reseñando novelas", y tenía para con ella un sentimiento si no despectivo, sí, como adelanté, tenso, ambivalente. El crítico, que aún quiere ser escritor, se ve abrumado por la cantidad de novelas que tiene que leer; nunca paran de publicarse, y por más a conciencia y críticamente que se intente trabajar con la que se tiene entre manos, la cantidad de publicaciones parece volver inútil el trabajo. Además, 
el trabajo es insalubre, agotador y mal pagado; pero lo más nocivo de todo esto, para Connolly, es que contaminará la escritura posterior con los tics del oficio. Es esta una idea que tendrá más desarrollo en Enemigos de la promesa, pero ya se hace manifiesta desde este ensayo temprano: las escrituras otras, con las que el artista potencial o eventual se ve obligado a ganarse la vida, son nocivas para la que se anhela como la escritura principal. El escritor, obligado por las circunstancias a utilizar la palabra, su materia prima, su dominio, para obtener los ingresos necesarios con que poder dedicarse a su obra, la daña a su vez, paradójicamente, mediante una práctica que se cree espuria. Muchas veces, como lo afirma en la "Introduction”, esta práctica se vuelve luego única; la selva ha devorado todo, el novelista se convirtió en crítico. En visos de autor, para demostrar que no se ha entregado del todo a la selva, se permite, dentro de este ensayo, un diálogo ficcional, una parodia de dos críticos arquetípicos y de las novelas contemporáneas que se ven obligados a analizar. Por un lado, está Untuoso, el que ya no lucha contra la selva: todo le parece lo mismo, y todo le parece bien; perdió su capacidad de discernimiento, las habilidades que lo hicieron apto para ese ejercicio. Por el otro, Novato, el recienvenido: llegado de la universidad, con altos estándares estéticos, quiere ayudar al autor mientras advierte al lector; y no quiere caer en las tentaciones del oficio. Ambos representan extremos, grotescos en su deformación, que se deben evitar; las Escila y Caribdis que el crítico que Connolly imagina tendrá que sortear en su viaje.

En baja por agotamiento, Connolly se posiciona como el espectador de una experiencia de la que ya no participa; al no comprometerlo, como un delator, se permite denunciar algunas actitudes del oficio: los esfuerzos por desalentar a tanto autor prolífico; las esperanzas iniciales de ser el primero en dar alarma sobre una nueva joya literaria que se truecan luego en el placer de desacreditar a una antigua y consagrada; la imposibilidad de sobrevivir en un campo donde la generalidad de los libros son ilegibles. El ensayista, basado en su experiencia, hace acontecer en la escritura las razones de una distancia; las razones de su distancia, verdaderas, como todas las afirmaciones que estoy analizando, sólo porque son el presente de una escritura que tiene por fundamento las prácticas y las imaginaciones de un autor particular que, en vez de plantearse como axiomas, son los epigramas de un personaje, el del ensayista, que se muestra en la misma escritura, pone el cuerpo, mediante los procesos de autofiguración que vengo estableciendo. 
Una de las figuras de autor que toma forma en estos ensayos, y en especial en este último, es la del crítico como escritor frustrado. Todo crítico tiene un tema de especialidad: aquel sobre el que no pudo escribir una novela, y su función es demostrar que los demás tampoco pueden hacerlo; a fuerza de insistir y demostrar, se acaba convirtiendo en una autoridad sobre ese tema, y la revancha está cumplida. Es esta una de las posibles tensiones entre dos funciones interdependientes del campo literario. También puede verse, en orden inverso, la posibilidad de la crítica como una de las causas frustrantes. Por la cantidad de novelas que ese crítico 'destruye', en revancha, la novela lo rechaza, lo hunde en esa escritura otra. Tensiones de los roles -el crítico que mata vicariamente al artista que no pudo ser; el artista que rechaza la autoridad, la legitimidad del crítico- y tensiones de la escritura -escribo sobre lo que no-escribo, y lo que no escribo, amenazado, me condena a no escribirlo--. Connolly, en vez de separar estas funciones, y objetivar sus cualidades específicas y diferenciales, las pone a medir fuerzas en la misma figura: la del crítico que quiso ser escritor y, como no pudo, indaga, ensayando, las causas de esa imposibilidad; y, al indagar, se aleja cada vez más de su objetivo primario, porque una escritura rechaza para él a la otra. Una tragedia: la del espectador que, viendo qué tendría que hacer que no hizo para ser protagonista, se vuelve cada vez más espectador, y se resiente por eso, culpablemente, contra el protagonista que no pudo ser. Tensiones subjetivas de posiciones objetivas del campo literario.

Más allá de lo que Connolly opine sobre la profesión de crítico, es una profesión de hecho, y tiene su lugar reconocido en todos los campos literarios. Se trata, según su punto de vista, de un mal necesario, y es por eso que se permite algunos consejos; no sin antes decir que sólo se puede llegar ahí forzado por las circunstancias, dado que nadie lo haría por su propia voluntad. Al decir que no se debe elogiar, porque los elogios se vuelven anticuados, está diciendo que se debe practicar una escritura que pueda ser reimpresa y releída con el tiempo, más allá del carácter periodístico y supuestamente efímero que estuvo en su génesis, rasgo que siempre Connolly, en tanto artista que se ve forzado a hacer únicamente de crítico periodístico, intentó cuidar en su escritura ${ }^{59}$, y que destaqué en el primer capítulo. Por otro lado, el posicionamiento en el campo literario: si reseñas un libro que te gusta, escribe para el autor; en caso de cualquier otro,

\footnotetext{
${ }^{59}$ Cabe recordar aquí una vez más que, después de La tumba inquieta, que dijimos cierra esta primera etapa de su obra, todos los demás libros de Connolly son recopilaciones de ensayos aparecidos en diarios y revistas, a excepción del brevísimo Cien libros clave del movimiento moderno.
} 
escribe para el público (no me detengo aquí dado que lo voy a tratar específicamente en el quinto capítulo). Otro consejo está basado en la ética profesional: hay que leer los libros que se reseñan $-y$ si llama la atención sobre este punto quiere decir que no todos lo hacen-, pero hay que leer apenas una página para saber si el libro es digno de una reseña -no perder el tiempo, hay demasiados libros, no contaminarse-. Por último, y a título personal, no hay que reseñar libros de amigos, porque la crítica no tiene una relación amistosa y afable con los libros, recordemos que se trata de algo así como una revancha.

De lo que se trata, por tanto, y en la medida de lo posible, es de publicar un trabajo bien hecho, que tenga algunas de las cualidades estilísticas de la literatura y que así le permitan ser releído, perdurar, ubicando a la vez al crítico en una posición del campo que no esté tan alejada de su objetivo primero que fue el de autor, protagonista. Más allá de sus quejas, forzado a ello, trata de buscar una posibilidad del ensayo que no lo aleje, no lo enfrente, a la posición del escritor de ficción. Y es por esto que este último ensayo termina con un lamento nostálgico, considerando la posibilidad de volver a la práctica, y ejercer una de sus funciones que, por cómo se la menciona, le parece valiosa: la capacidad del crítico, en cuanto conocedor de primera mano del sistema literario, de juzgar y posicionar las obras, según sus valores estéticos, dentro de la tradición; decirle al público el justo peso de una obra, lo que esa obra vale con respecto, y en relación, a otras obras anteriores y contemporáneas. Estas afirmaciones que deducimos del final del ensayo, y que voy a ampliar en el último capítulo, están muy cercanas a las funciones que establecen para la crítica tanto Harold Bloom como Pascale Casanova $^{60}$.

Éste es Connolly en persona (en tanto máscara pública) que, mediante el acto performativo de la escritura, se va creando para sí a la vez que, desde que decide publicar ese devenir, se presenta a su público; como en una obra modernista, el ensayo se convierte en escenario de un actor que se autofigura espectador. La búsqueda que preside y persigue esta escritura es la de las causas del fracaso de una promesa autoral; algo se ha hecho mal pero aún no se sabe qué. La introspección queda justificada en la búsqueda de esa falla. La autobiografía del escritor de ficción queda justificada por el

\footnotetext{
${ }^{60}$ Las ideas de tradición y canon siempre están presentes en la cosmovisión literaria de Connolly; y en Cien libros clave del movimiento moderno (1965) estableció su propia lista de obras canónicas, aunque la limitó a cien libros, al movimiento modernista y a las lenguas que podía leer y, por tanto, juzgar de primera mano el valor estético de las obras.
} 
interés que antes despierta su obra creativa ${ }^{61}$, buscamos en la lectura los procesos mediante los que un sujeto se convierte en artista; en cambio, en el caso de Connolly, asistimos a la autobiografía dispersa, ensayística, fragmentaria, en tanto difícil de justificar $^{62}$, de un no-autor: se muestran y se buscan las causas de por qué alguien totalmente preparado, y dotado, para esta actividad en particular, no logra, sin embargo, realizarla ${ }^{63}$; y, quien se acusa, se excusa, el resultado de esa búsqueda (resultado en tanto a escritura, no en tanto conclusión) es, paradójicamente, la obra; la obra que entonces se justifica a sí misma. El relato del fracaso de una obra es la obra, como en el caso de Proust el relato de un deseo de escritura es la escritura de la misma novela que lo dramatiza.

Connolly deviene ensayista en tanto autor ficcional fracasado. En todos los ensayos analicé los procesos de autofiguración mediante los cuales se crea una figura tan particular del campo literario como es el hombre de letras, un crítico y ensayista que en el caso de Connolly lo es por defecto. Cuando escribe sobre sí o el novelista o el crítico lo que importa no es la validez general del predicado (que puede tenerla) sino que se trata de una experiencia, o de una reflexión sobre una experiencia, de este sujeto escriturario en una coyuntura particular. Y lo que más interesa, en este caso, es que los epigramas de Connolly no se presentan como axiomas o dogmas sin contexto; ahí está, sosteniéndolos o no, la figura que el propio autor construye para sí y para nosotros, el cuerpo de una experiencia, un saber, una escritura. Escamotea la falacia de la objetividad proponiéndose como sujeto de una experiencia de saber y objeto de una escritura; el saber, cierto saber, está fundado en el sujeto, sometido a los trazos de un cuerpo. Se dramatiza un saber, y se espectaculariza la subjetividad que lo enuncia. Estos elementos, que el lector debe recomponer, le dan elementos más complejos para juzgar la formación, el asiento y el estilo de ese saber; un diálogo más frontal con ese otro, también, cuerpo de saber.

La pereza, el hedonismo y la molicie de los sentidos satisfechos; la ensoñada sangre celta; los altos estándares estéticos de un lector con una educación y un gusto

\footnotetext{
${ }^{61}$ Ricardo Piglia solía afirmar que escribía ficción para justificar la posterior publicación de sus diarios, que así se convertían en el centro de su obra.

${ }^{62}$ Existen casos anteriores de no-escritores famosos, pero sus procesos de búsqueda y fracaso autoral quedaron solamente plasmados en sus diarios; en vida no presentaron al escritor fracasado como figura de autor en el campo en el cual se insertaban. Es el caso de Henri-Frédéric Amiel (1821-1881) y de Charles Du Bos (1882-1939).

${ }^{63}$ Como voy a poner en claro en el próximo capítulo, es por esto que las advertencias o consejos de Connolly son casi siempre negativos; dice lo que no hay que hacer, porque él lo hizo, pero no clarifica tanto lo que hay que hacer, porque no lo experimentó.
} 
superiores; indagaciones sobre el modo de vida y de trabajo que posibiliten un artista y su obra; búsquedas de las fallas que en su caso han malogrado un potencial reconocido; escrituras de esa no-escritura; la autofiguración de un artista fracasado y de un hombre de letras exitoso a su pesar; esas son las huellas, espiraladas, que los ensayos de Connolly van trazando. 


\section{Los libros mayores: Enemigos de la promesa y La tumba inquieta}

Como adelanté en capítulos anteriores, Cyril Connolly escribió en su carrera, además de una novela, The Rock Pool (1936), dos libros de ensayos concebidos como tales; los demás, de los que termino de dar alguna muestra al analizar, son recopilaciones. El primero, Enemigos de la promesa (1938), se divide en tres partes: la primera trata del estilo, de la lengua literaria, estableciendo una dicotomía entre escritores 'mandarines' y 'modernos', analiza pros y contras, y sobre el final 'prescribe' qué tomar y qué dejar de cada tendencia; la segunda parte se ocupa de los 'enemigos de la promesa' (familia, periodismo, política, drogas, etc.), estableciendo algo así como una regula para prevenir a artistas principiantes; y en la tercera aparece su autobiografía de formación. Todo el libro tiene una ambición: durar diez años, y dar la receta para escribir libros que duren por lo menos diez años (no debemos olvidar que se publica en 1938, en la inminencia de la Segunda Guerra). Connolly vivió obsesionado con las obras maestras, y puso tanto énfasis en establecer las condiciones para crear una que eso tal vez le impidió escribirla; desde ese punto de vista es un texto similar a La preparación de la novela, de Roland Barthes.

Su otro libro de ensayos, La tumba inquieta (1944), es personalísimo y misceláneo: meditación, reflexión personal, divagación, con un entramado compuesto de memorias, extractos de diarios, citas, pensamientos; podríamos decir que se trata de un texto sinfónico, con movimientos que vuelven y varían: el amor, la literatura, la religión, la muerte, etc. Fue reseñado por Cortázar en la revista Sur, y luego traducido por Ricardo Baeza para la editorial.

Me concentraré ahora en la descripción y el análisis de estas dos obras mayores de Connolly, que representan la cumbre de su trabajo, y fundamentan su fama póstuma.

\subsection{Enemigos de la promesa, 1938. (Enemies of Promise)}

Dos años después de The Rock Pool, Connolly escribió su ensayo de crítica literaria más ambicioso, Enemigos de la promesa, donde da las claves para escribir una obra maestra, y previene contra sus enemigos. Leemos en la primera parte:

Es la sobremesa de un día sofocante. El almuerzo ha consistido en una tortilla, vichy y melocotones. La mesa está a la sombra de un plátano, y un gramófono suena en la habitación contigua. Siempre procuro escribir por la tarde, pues corre suficiente sangre irlandesa por mis venas para que tema el temperamento irlandés. La forma literaria que éste adopta, conocida como el "crepúsculo celta", consiste en una adicción a la melancolía y un uso exagerado de palabras, y los buenos escritores irlandeses exorcizan al demonio disciplinándose en una cultura extranjera y más 
rigurosa. Yeats traducía del griego, mientras que Joyce, Synge y George Moore huyeron a París. En cuanto a mí, el latín de Augusto y el inglés neoclásico me parecen los mejores correctivos, pero no siempre dan el resultado apetecido y, si escribo cuando oscurece, las sombras del crepúsculo esparcen sus tonos purpúreos del principio hasta el fin de mi prosa. (Connolly 2005, 40)

Y enseguida pasa a comentar que no le es posible escribir de mañana porque se acuesta muy tarde. Se delinean ya en este breve párrafo tres elementos que van a configurar la estructura tripartita del libro: los problemas del estilo y su relación con el canon; los peligros, temperamentales y sociales, que acechan al escritor; y la autofiguración del ensayista, que sustenta las nociones expresadas. Parece un comienzo extraño para un libro de crítica literaria, más si tenemos en cuenta que la tercera parte del libro es una autobiografía de formación. ¿Cuál es su función? ¿Qué clase de estructura forman estos textos? Connolly lo explica así en la introducción: "Lo cierto es que entre la última sección y las anteriores existe una armonía que si no resulta evidente, es en todo caso intencionada, la misma relación que existe entre un texto y sus ilustraciones" (2005: 3132). Y funciona así en dos sentidos: como ejemplo estilístico de lo prescripto en las dos secciones anteriores, y como "autobiografía de ideas", de donde quedan excluidos todos los episodios que no hayan tenido "intervención directa en la formación de las especulaciones literarias en las que se basa la primera parte" (2005: 32). Connolly: el artista fracasado y ocioso que hace gala de tal, pero que, sin embargo, nos dice cómo se debe escribir un libro duradero y, además, nos da una pequeña demostración de que él podría hacerlo, y al mismo tiempo nos cuenta por qué.

Si bien comienza a escribir este libro en medio de una gran agitación social ("Ésta es la época del año en que estallan las guerras", 2005: 39), la preocupación de Connolly es estrictamente literaria ${ }^{64} \mathrm{y}$, en tanto tal, sus primeras indagaciones se concentran en lo más específico del arte literario: el trabajo del estilo y la estructura. Los libros contemporáneos, nos dice, duran muy poco, quedan fuera de la circulación de lecturas una vez que aquellas cualidades que contribuyeron a su éxito desaparecen; por tanto, es preciso indagar sobre cierta calidad que mejore con el tiempo. Así, entre las primeras causas de fracaso en la duración de las obras literarias, menciona la forma panfletaria, que considera una manera espuria de dirigirse al público; halaga, grita,

\footnotetext{
${ }^{64}$ De manera un tanto chocante, pero que deja bien en claro la postura estética y social de Connolly, afirma: "Sin embargo, supongo que la mayoría de mis lectores se habrán adaptado a la situación actual, pues al fin y al cabo escribo para los burgueses como yo. [...] mi manera de escribir, así como las cosas sobre las que me gusta hacerlo, no atraen a los miembros de la clase obrera, y tampoco puedo tenderles ningún puente hasta que estén preparados para cruzarlo. Así pues, os saludo, mis educados semejantes burgueses, cuyos intereses y dudas comparto" (2005: 42).
} 
sermonea, y así atrae a un público interesado, "indigno”, que luego abandonará al autor, y la obra será olvidada una vez que las circunstancias actuales que la motivaron ya no existan. Otra causa, que ampliará en su momento y que resulta paradójica, es cierto tipo de éxito del libro. Por un lado, la inflación, que terminará repercutiendo de forma negativa en la reputación literaria, a la manera pírrica; las palabras altisonantes de los suplementos, devaluadas por su repetición, pueden generar un éxito desproporcionado que hace que más tarde el público se resienta contra su best-seller de turno ${ }^{65}$. Por otro, las imitaciones demasiado exitosas; un autor escribe un buen libro, donde hace ciertos descubrimientos estilísticos de valía, pero luego, por eso mismo, es demasiado imitado y las imitaciones tienen éxito y puede que el buen libro se hunda con ellas cuando pase la moda excesiva (aquí Connolly cita el caso de Hemingway, al que por esos años acosaba el éxito tanto de ventas como de discípulos y películas).

En contraste cita el caso de los libros de E. M. Forster, que, escritos hace décadas, encuentran en ese momento nuevos lectores y seguidores, con un éxito sin estridencias, retardado, duradero. Parte de ese éxito se debe a causas coyunturales, donde las parábolas humanistas de las novelas de Forster pueden ser releídas con otra luz en la inminencia de la guerra; pero, también, a la llaneza de su escritura, un arte posible gracias a la seguridad que el autor tiene en la verdad de sus convicciones y la fuerza de sus emociones. Para no caer en las valoraciones extraliterarias, o intentando salir de ellas, Connolly comenta, con su característico estilo epigramático, que los escritores que no están muy seguros de lo que quieren decir son los que escriben en un estilo recargado, para ocultar su ignorancia o encontrarse inesperadamente con una verdad, como aquellos que tienen dificultades para crear personajes son los que se gozan en una excelente escritura. El estilo llano y nada enfático de Forster hace que sus obras se relean con facilidad, y no contiene nada de lo que uno pueda cansarse; asimismo, no ha sido imitado. Éstas son las causas de su éxito, y un ejemplo de lo que Connolly analizará en los siguientes capítulos de la primera parte de su libro.

En este ensayo suyo, por tanto, la cualidad diferencial de los escritores estará centrada en el estilo; cree que, si bien la crítica suele concentrarse más en el aspecto sexual o económico, la mejor forma de diagnóstico se encuentra en el estilo. Un párrafo de un autor, aun aislado del libro al que pertenece puede decir al experto cuán bueno es

\footnotetext{
${ }^{65}$ Según Connolly lo que el best-seller se plantea es un problema de seducción; puede que en un primer momento atraiga a los lectores, pero poco más tarde los verá marcharse en fila. El gran escritor, en cambio, crea un mundo propio, y su público se enorgullece de vivir en él (2005: 46).
} 
un escritor y a qué influencias estuvo sometido. Y advierte: "Los críticos que ignoran el estilo están expuestos a englobar a buenos y malos escritores en apoyo de unas teorías preconcebidas" (2005: 45).

Después de este primer capítulo presentativo, y antes de proseguir con su análisis, Connolly problematizará la noción de estilo para llegar a una definición (que, según vengo estableciendo, es válida dentro de este ensayo) ${ }^{66}$. Según él, es imposible escribir sin estilo, dado que no se trata de una manera de escribir, engalanada o seca, sino de la relación que existe entre la forma y el contenido. Por tanto, un mismo escritor tiene más de un estilo, dado que éste varía con el asunto y la forma elegida. Además, está condicionado también por la concepción que tenga de su lector, y varía según se dirija a sí mismo, a un amigo, o a una amplia audiencia; si se dirige a una clase culta, a una clase deseosa de educarse o polemiza con un jurado hostil. Coincidiendo con los postulados que más tarde formulará Eagleton, y que desarrollé en el primer capítulo, al tratar la relación del hombre de letras con una esfera pública de amplia coherencia, afirma Connolly: "Este rasgo es menos perceptible en escritores que viven en una época estable, pues pronto establecen una relación con un lector en el que pueden confiar, y éste, en general un hombre de la misma edad, gustos, educación y situación económica, permanece a su lado durante toda su vida" (2005: 49). En estos períodos, que en Inglaterra Connolly ubica entre fines del s. XVII y principios del XVIII -su época preferida-, la coherencia en la relación entre un escritor y su público hacía que fuera "imposible escribir mal"; el escritor podía hacerlo naturalmente, sin afectación, y las palabras expresaban lo que significaban. Así, la definición a la que Connolly da forma afirma que el "estilo es pues la relación entre lo que un escritor quiere decir, su asunto y él mismo- o los poderes que posee: entre la forma de su asunto y el contenido de sus partes" (2005: 49). Y esta relación, según Connolly, se manifiesta en el lenguaje, que será la clave de su indagación.

Creará entonces una oposición binaria a los efectos de este análisis, polarizando ciertas características sobresalientes del lenguaje de escritores en lengua inglesa siempre aportando ejemplos-, para tratar luego de evaluar sus pros y contras con el fin de ofrecerlos como modelos de escritura, dado que el objetivo de estos capítulos es "ayudar a aquellos cuyo temperamento les impide comprometerse con un solo grupo"

\footnotetext{
${ }^{66}$ Como primera medida Connolly toma una definición de estilo del diccionario (sin citar la fuente), según el cual se trata de "las características colectivas de la escritura, dicción, expresión artística, manera de presentar las cosas o métodos ornamentales propios de una persona, escuela, período o asunto, el modo de mostrar esas características" (47).
} 
(2005: 52). Estos estilos opuestos serán el “mandarín” y el "moderno" (el sublime o el escueto, el ornamental o el funcional, el barroco o el modernizado). El estilo "mandarín" es el de aquellos que intentan diferenciar al máximo la palabra escrita de la hablada; según Connolly, es el de quienes tienden a hacer que su lenguaje transmita más de lo que quieren decir o de lo que sienten. Suele caracterizarse por el excesivo uso de palabras, sobre todo de adjetivos y de adverbios innecesarios. El lenguaje tiende a sobrepasar la idea o el sentimiento que expresa, volviéndose éste ineficaz y aquellos falsos debido al desequilibrio, desajuste o desproporción de la relación formacontenido. Al ser así el contenido inferior a la forma, el lenguaje se vuelve recargado; evidencia un fingimiento, una ignorancia que vuelve el estilo artificial (2005: 57).

Esta tendencia al ornamento presenta una oposición puritana. A medida que un escritor siente, piensa o lee con más seguridad, se encuentra más capacitado para efectuar experimentos con la técnica, incluso hasta simplificarla. Si el autor teme que los lectores sean más inteligentes que él hará uso de la mistificación; por el contrario, si se siente más inteligente, escribe con sencillez. La sencillez en este caso no es pobreza sino seguridad, certeza de la calidad del pensamiento o la emoción; por tanto, se da una adecuación del lenguaje con lo que expresa, que es la definición del buen estilo: "un autor logra un buen estilo cuando su lenguaje realiza lo que se requiere de él sin timidez" (2005: 58).

Sin embargo, y como es de suponer, no todo son críticas al estilo mandarín, lo que haría que el ensayo carezca de búsqueda y variación. En su mejor versión, produce la expresión más rica y compleja de la lengua inglesa, con sus frases largas, el amplio uso de tiempos verbales, metáforas, terminología latina y sutileza; se presupone que tanto autor como destinatario tienen mucha cultura y tiempo. Entre los mejores ejemplos Connolly cita a Johnson, Gibbon, De Quincey y Ruskin; sus últimos grandes exponentes fueron Walter Pater y Henry James, capaces de expresar en sus complejas frases las inflexiones más sutiles de la sensibilidad y el significado. El riesgo que corren, sin embargo, es que esa intrincada frase acaba englobando todo en su textura, y el autor, prisionero de ese estilo, no puede expresarse de otra manera, y así "son como esos pájaros que construyen complejos nidos en los que se sienten tan satisfechos incubando un guijarro como un huevo" (2005: 58). Estos escritores, como analicé anteriormente con respecto a la crítica, fueron también típicos de cierto estado del campo literario; su público era reducido y semejante; el advenimiento de otra época abarató las novelas y amplió el público lector, con otras exigencias de ocio y de cultura. 
Según Connolly aquí se inicia la lucha entre literatura y periodismo -que da lugar al agón estilístico que trata en este libro-; y formula su citado epigrama: "La literatura es el arte de escribir algo que se leerá dos veces, el periodismo es el arte de lo que se aprende de inmediato, y los dos requieren técnicas independientes" (2005: 59). En el periodismo no puede haber suspensos ni elipsis ni efectos retardados ni alusiones veladas. Como el periodismo avanzaba más rápido, la literatura se vio en una encrucijada: o se apartaba del periodismo para convertirse en un arte elitista o aprendía de él (este caso en muchos aspectos similar al que antes analicé con respecto a la crítica). La prosa entonces empezó a imitar ciertos recursos del periodismo dando como resultado el "movimiento moderno", una reacción reformista contra el estilo mandarín que proporciona el lenguaje de la época en que Connolly hace este diagnóstico; este lenguaje periodístico es conversado, tiende al habla, y si no consiste en lo que la gente dice, "no debería incluir nada que no pueda decirse" (2005: 61). El estilo introspectivo y meditativo de los mandarines se convierte en otro, más sencillo y argumentador, estableciendo una nueva relación con el "tú" del público lector. En sus peores manifestaciones, el estilo moderno será demasiado parecido al periodismo - un peligro que acecha al artista, como voy a analizar en el próximo apartado-, en las mejores, parafraseando la máxima de Brummell, tratará de llamar la atención lo menos posible, como el hombre bien vestido; frases cortas, sencillez sintáctica, palabras cotidianas, ausencia de subordinación.

A un momento de inflación le sigue otro de deflación, a la complicación la simplificación. Pero todos los escritores que a Connolly le interesa analizar comparten ciertas creencias: la importancia de su arte, la santidad del artista y su vocación; una actitud que ya desde entonces se llama "torre de marfil". Si bien se ocupa de autores que escriben en lengua inglesa, afirma, como buen francófilo, que el mundo intelectual que habitan los artistas modernos es heredado de Flaubert y Baudelaire. Esta actitud se irradia desde París - capital de la república mundial de las letras-, y obedece a la consolidación de un campo literario que se rige exclusivamente por sus propias reglas. El artista que acepta la religión de la torre de marfil se entrega a un arte cuya recompensa es la perfección, y ésta se logra mediante una separación del mundo profano, ajeno, y el establecimiento de criterios artísticos que nada tienen que ver con los de quienes no son artistas. Dentro de esta "religión", Connolly establece distintos papeles: “el Sumo Sacerdote (Mallarmé, Joyce, Yeats), el Dandi (Firbank, Beerbohm, Moore), El Observador Incorruptible (Maugham, Maupassant) o el Filósofo Objetivo 
(Strachey, Anatole France)" (2005: 73). Pero el papel que no asumirá es el de Luchador o Auxiliador. En este sentido la posición de Connolly es tajante, más teniendo en cuenta el contexto europeo -se salía de una gran guerra y se estaba por entrar en otra-, pero responde a su afán delimitador, al repliegue sobre sí mismo del campo literario y, antes que nada, a la finalidad de su libro: cómo se escribe un libro que sobreviva a sus circunstancias y vicisitudes, qué es lo que sobrevive; una pregunta por lo literario en sí.

Como actitud extrema de la búsqueda estilística, Connolly se ocupa de diseccionar el dandismo literario. El dandi se presenta como lo contrario del luchador, del reformador; y siempre termina aceptando el statu quo, o por lo menos no desea cambiarlo, aun cuando sus valores sean distintos. En sus escritos, no busca la justicia ni la verdad; todos sus anhelos se dirigen a la búsqueda de la belleza, y la belleza es un momento de las cosas, que el artista trata de atrapar en su obra. Es por eso que suma a su interés exclusivo por la belleza una esmerada preocupación por los problemas de plasmarla, una reflexión técnica. Horror por el cliché y consideración hacia las palabras usadas, evitar lo gastado y aburrido, son algunas de las características del dandismo en su búsqueda de la perfección; porque el dandismo no es sino una forma del perfeccionismo, una actitud ambivalente, porque en tanto extrema, puede llevar a extinguir aquello mismo que busca. Como búsqueda del arte por el arte, de la perfección en el arte, puede producir un arte imperfecto debido a la violencia del homenaje que le rinde. El perfeccionista lleva a cabo un proceso de despojo personal, eliminando lo que sobra, también lo excelente, para quedarse solamente con lo que es más excelente aún. Es por esto que para Connolly son ascetas y místicos, el lugar donde los extremos se tocan. En última instancia, la perfección lleva en sí un deseo de limpidez que es deseo de muerte. Corren el peligro del silencio o la degradación; y es una actitud compleja de mantener en el tiempo. Algunos mueren antes de que eso suceda, como Tibulo y Leopardi; otros se retiran, como Walpole y Beckford; y unos pocos siguen siendo perfeccionistas hasta el fin, como Horacio, salvados por una mente ágil y la obediente disciplina del arte, nos dice Connolly.

Si de Ronald Firbank puede aprenderse la importancia de la frivolidad (things of little importance), de T. S. Eliot, al que también considera dentro del dandismo, y que en sus primeros poemas explotó esa veta, puede uno aprender a no avergonzarse de tomar prestado, y a asimilar esos préstamos: el trabajo con materiales ajenos, heterogéneos y pertenecientes a distintas tradiciones es una característica del modernismo que tendrá amplia aceptación e influencia. Firbank creó un mundo tan 
idiosincrático y extravagante que tuvo muchos admiradores pero pocos discípulos; por su parte, Eliot trabajó con sentimientos y estados hasta entonces considerados antipoéticos, grises, que supieron captar un espíritu de la época (Zeitgeist) que influyó en las nuevas generaciones; una idea de futilidad, engendrada en gran parte por las desilusiones provenientes de la Primera Guerra Mundial, que es común a otros autores contemporáneos importantes. En cierto modo se trata de una extensión de la actitud "torre de marfill", dado que se basa en la incredulidad en la acción, en el compromiso, y en una puesta en crisis de los valores morales tradicionales de occidente. El joven inteligente y desengañado se convierte en un prototipo de la época, ya no cree en la guerra y todavía no cree en la paz; lo estéril se vuelve diagnóstico y conducta. El estilo lírico de los dandis, según Connolly, acaba madurando con la edad y se convierte en el mandarín.

A través de este vaivén de estilos, el autor va deduciendo sus distintas características y las de quienes los practican para tratar de escoger cuál es el que conviene a su tiempo -si bien reconoce que estos dos estilos interactúan y, al igual que los partidos políticos, se suceden en el poder con el correr del tiempo-. En una nueva formulación, clasifica a estos estilos como

el realista o vernáculo, el estilo de los rebeldes, periodistas, adictos del sentido común y observadores no románticos del destino humano, y el mandarín, el estilo artificial de los hombres de letras o de los que ocupan cargos de autoridad y hacen de las letras una ocupación en su tiempo libre. (2005: 94)

La condena penal de Oscar Wilde por homosexualidad y ofensa a la moral pública, siendo como era un personaje central del campo literario inglés, instauró una visión decadente y peligrosa de los practicantes del arte por el arte, y el romanticismo inmediatamente posterior se volvió más robusto y viril, amante de la cerveza y los sencillos paseos por la campiña inglesa. Hubo que esperar al menos veinte años para que las figuras centrales del grupo de Bloomsbury se reinstalaran en el poder como los nuevos mandarines, con una sostenida crítica de la hipócrita moral victoriana. Uno de los libros capitales en esa operación fue Victorianos eminentes (1918), de Lytton Strachey, que se ocupaba de bajar del pedestal a cuatro importantes figuras de la era victoriana $^{67}$, pero lo hacía con una prosa musical y refinada, que gustaba a la vez que destruía. Como figura central del grupo destaca a Virginia Woolf, que fue

\footnotetext{
${ }^{67}$ A saber: el cardenal Manning, prelado católico; Florence Nightingale, reformista del sistema sanitario inglés; Thomas Arnold, director de la Escuela de Rugby y reformista de la enseñanza; y el general Gordon, que sacrificó su vida en la defensa de Jartum.
} 
complejizando su estilo a medida que avanzaba en sus publicaciones; como caso ejemplar, la escritura en algunos de sus libros, según Connolly, "parecía tener el peor defecto del estilo mandarín, la capacidad para tejer capullos de lenguaje a partir de nada" (2005: 99); sin embargo, en sus mejores obras, como en el caso de Las olas (1931), la complejidad de ese estilo sirve al propósito de "exponer el misterio de la vida" (2005: 100), las pequeñas diferencias, los matices de sentimientos, que un grupo de personajes experimenta con el paso del tiempo, convirtiéndose en un instrumento intrincado y muy sutil.

Sin lugar a dudas, el más famoso e influyente de los nuevos mandarines fue Marcel Proust, y como tal, exhibe sus mayores virtudes y defectos. Hay muchos pasajes en los que la complejidad de la prosa es acorde a la emoción que intenta reproducir o suscitar; una emoción difícil y sutil expresada en prosa difícil y sutil. Pero en otros pasajes la prosa sigue siendo igual aunque la emoción sea de otra calidad y no alcance a emparejarla, se vuelve repetitiva. El caso de James Joyce se presenta más difícil de clasificar, pues sus dos primeros libros de prosa, Dublineses y Retrato del artista adolescente, están escritos en prosa moderna; Ulises está escrito en muchos estilos, y Joyce, como estilista que fue, parece hacer más bien un balance de los estilos y posibilidades de la lengua inglesa que esforzarse en la búsqueda de un estilo personal, de autor. Y Finnegans Wake (que aún no había aparecido bajo ese nombre cuando se publicó Enemigos de la promesa), si algo puede decirse de su estilo, “es un libro mandarín que exige, y exige en vano, un ocio absoluto, la educación más amplia y una paciencia indesmayable por parte del lector que desee entenderlo" (2005: 106), opina Connolly $^{68}$.

La cualidad común a todos los mandarines, en sus peores momentos, es la inflación, ya sea de lenguaje o imaginación. Pero tuvieron gran éxito en la primera posguerra; el culto a la belleza, la religión de la palabra y significados exclusivos para los iniciados fueron una conjunción válida para los jóvenes individualistas, descreídos ya de los nacionalismos y los sentimientos populares. La idea de un arte difícil, exclusivo, les permitía poder inflar sus propias vidas y les daba una profundidad e importancia que no podían encontrar en otro lado.

\footnotetext{
${ }^{68}$ Afirma que no se ocupa por extenso de estos autores dado que cualquier artista interesado en el arte de la palabra ya tiene que conocer El castillo de Axel (1931), de Edmund Wilson; el libro más importante que existe acerca de ellos. Pocos años más tarde, a la muerte de Joyce, volverá a decir lo mismo, como precisé en el correspondiente ensayo.
} 
A la prosperidad repentina de la posguerra le siguió la depresión, y se produjo un movimiento de reacción contra los nuevos mandarines. Según Connolly, este ataque vino desde tres frentes. El primero, liderado por Somerset Maugham, provenía de aquellos escritores de una generación anterior que no se habían visto influenciados por Pater, Ruskin y Henry James. La prosa de Maugham, clara, eufónica y sencilla; sus relatos con comienzo, nudo y desenlace, tenían por modelo a Flaubert y Maupassant, los maestros franceses del realismo. El segundo frente provenía de París, donde Gertrude Stein, el Joyce anterior a Finnegans Wake, y Ezra Pound abogaban por una prosa sin florituras, sin sobrantes, ajena a la tradición predominantemente inglesa. Y el tercero provino de algunos de sus coetáneos como D. H. Lawrence y Katherine Mansfield, con su escritura sensible pero sobria, indiferente a lo artificioso.

El escritor más influyente del nuevo vernáculo fue Ernest Hemingway. Según Connolly, su estilo sufre las limitaciones del realismo; proveniente del cuerpo más que de la mente, es bueno para expresar emociones pero ineficaz para fines intelectuales. Esta prosa, sin embargo, se adaptaba muy bien a sus objetivos, dado que sus relatos tratan sobre soldados, toreros, cazadores, boxeadores, etc., todos personajes muy apegados al valor de sus cuerpos, de emociones fuertes y simples; personajes y temas que quedaban fuera de la escritura de los mandarines. Pero Hemingway no pudo alejarse a tiempo de una horda de imitadores, y el cine sonoro volvió cliché al duro héroe que centraba sus libros; y él no varió, se repitió hasta parodiarse.

Connolly se detiene, y cita profusamente, en la valoración de la prosa vernácula de Somerset Maugham; estaba éste en contra de la prosa barroca y arcaizante de Gibbon y el Dr. Johnson, de De Quincey y Walter Pater: "Escribir buena prosa es cuestión de buenas maneras. Al contrario que la poesía, es un arte civil... la poesía es barroca" (Maugham, citado en Connolly 2005: 123), y los escritores del período barroco le parecen poetas extraviados. Al declamatorio barroco, Maugham opone la elegancia y la moderación del rococó, donde se escribió la mejor prosa; una prosa que debe parecerse a la conversación de un hombre educado, ocioso y sin necesidades apremiantes, despreocupado. La prosa perfecta es para Maugham la de Voltaire: lúcida, sencilla, eufónica y vivaz (2005: 124). Para Connolly, más allá de su gusto por Maugham, los mismos pasajes citados cargan los defectos de ese estilo: un vocabulario insípido, periodístico, que terminará por ser cliché; falta de aliento en las frases demasiado breves para la vista y el oído. 
Muchas veces la opción por la prosa vernácula posee un fundamento ideológico, político, que tiene que ver con la legibilidad -es por eso que se asocia con autores de izquierda, mientras que la prosa en estilo mandarín queda para los defensores del statu quo-. En este punto realiza Connolly un experimento: 'cita' un extenso pasaje de prosa novelística. Informa luego que se trata de un entretejido de textos de tres autores diferentes: Isherwood, Orwell y Hemingway. El objetivo es mostrar que este vocabulario, frases, dicción, vuelven indistinguibles a unos autores de otros; se trata de frases banalizadas, estandarizadas, por el periodismo, el cine, la propaganda y los bestsellers. Escribir para las masas es decir lo que otros también dicen, y como ellos lo dicen, lo cual atenta contra la originalidad y la innovación del arte literario.

Connolly comienza el último capítulo de esta primera parte, como si antes no lo hubiera hecho, diciendo: "Ya es hora de que exprese una opinión sobre la batalla entre los estilos. No digo que uno sea mejor que el otro, pues ambos tienen muchas cosas admirables. Lo que he afirmado es una relación entre ellos, una acción y reacción perpetuas" (2005: 131). Y, para esclarecer de alguna manera este sucederse, establece que los realistas se impusieron en los años anteriores a la guerra; desde 1918 a 1928 fue el período de los nuevos mandarines, y de 1928 a 1938 (año en que se publica este libro) ha predominado el estilo de los nuevos realistas. Pero este período parece estar llegando a su fin: su escaso vocabulario se ha visto desgastado por el éxito y el exceso de imitación; al tratarse de un lenguaje coloquial no resulta fácil separarlo del de los best-sellers y el periodismo. La literatura es un arte impuro; su materia, la palabra, puede ser tratada artísticamente, pero a su vez es el medio de comunicación de todas las personas y de muchos de los trabajos extra-artísticos. ${ }^{69}$ Es por esto que la prosa realista vernácula corre peligro de uniformidad y desgaste: "La prosa no sólo será discreta como las buenas prendas de vestir, sino tan uniforme como las malas" (2005: 136). Isherwood reconocía en privado (era amigo de Connolly) las limitaciones de este estilo, pero confiaba en la construcción como salida de esta dificultad; si su lenguaje es el que usa todo el mundo, su talento de novelista se demostrará en la exactitud de observación, la justicia de sus situaciones y la construcción de su libro.

\footnotetext{
${ }^{69}$ En este apartado Connolly vuelve a un tema que ya traté en el capítulo anterior: el del crítico como escritor fracasado: "Y los más implacables de todos ellos [los que no practican el arte y se resienten contra los que sí] son los jóvenes inteligentes que han fracasado como artistas y tan sólo aportan una esterilidad apasionada y un resentimiento oscuro y englobador en su examen del arte creativo. El objetivo de gran parte de esta crítica [...] es exclusivamente el de eliminar el estilo individual, desterrar la belleza imaginativa y el arte formal de la escritura" (2005: 136).
} 
Por su parte, el defecto de la prosa en estilo mandarín no es que sea poética, sino que muchas veces no es prosa, sino mala poesía. La prosa puede ser poética, lírica, pero estos elementos deben ser correctamente asimilados por el medio utilizado, para que sus ritmos y estructuras se correspondan con los de la prosa y no con los de la poesía ${ }^{70}$.

Es hora, para Connolly, de volver a exigir al lector; que el escritor no solamente escriba como habla, sino que escriba como habla su público, es condescender a la incultura, otorgarle un valor que no tiene. Para explotar enteramente su talento el escritor debe considerar al público a su misma altura; para escribir un libro que dure al menos diez años hay que escribir de manera que se exijan tanto los recursos de la lengua como la inteligencia del lector; a este efecto, tomará de los mandarines arte y paciencia, la búsqueda de perfección, el horror del cliché, los recursos de la frase larga y compuesta. Debe evitar a su vez sobrecargar con puro exhibicionismo un lenguaje sobrio y sutil, la mistificación y el titubeo, los arcaísmos y el exceso de alusiones clásicas, las falsas relaciones de arte y experiencia, las vagas especulaciones. De los realistas el escritor tomará la precisión y la lucidez, el sentido de la elipsis y la oportunidad, la capacidad de dar a las palabras su significado tópico corriente, la planificación en la construcción y ejecución de la obra (la sencillez muy trabajada), la poda, la corrección, cierta cualidad de prescindir de lo innecesario. A su vez se cuidará de tomar prestado la monotonía del estilo y el ritmo, la homogeneidad de la perspectiva, la desconfianza en la belleza y el culto a la violencia, la pedagogía y la propaganda.

Connolly ha demostrado la existencia de la batalla y de la alternancia en la victoria. En el momento en que escribe, decreta que cierto tipo de realismo está exhausto, pero no se trata entonces de optar por el estilo mandarín, sino de analizar y calibrar los pros y contras de cada uno para poder utilizarlos con sentido de la oportunidad, equilibrando la relación entre el dominio de la forma y el contenido intelectual y emocional que forman el estilo; en fin, de hacer una síntesis adecuada una vez hecho el análisis, romper el círculo de alternancia mediante la meditada combinación, "una extravagancia razonada" (2005: 144).

En la segunda parte de Enemigos de la promesa, "La sombra de la mostaza silvestre", Connolly analiza, como antes lo hizo con el estilo, el modo de vida de los escritores;

\footnotetext{
${ }^{70} \mathrm{Si}$ muchos poetas fracasados son luego malos prosistas poéticos, por su parte Connolly destaca que los buenos poetas suelen ser buenos prosistas, desde Shakespeare y Milton, pasando por Hopkins y Eliot hasta Auden.
} 
pues éstos no sólo deben encontrar y forjar un estilo que le permita a sus obras sobrevivir, sino también un estilo de vida que les permita llevarlas a cabo. Más allá de los talentos particulares de cada autor, Connolly cree que existen factores socioambientales que ayudan o dificultan su pleno desenvolvimiento. Lejos está de intentar un análisis sociológico de la situación del escritor inglés, sin embargo, no desconoce que la escritura en tanto actividad se desarrolla como parte de la vida material del escritor.

Es innegable, evidente, que un escritor, como cualquier otra persona, necesita dinero para vivir; y, en la mayoría de los casos, sobre todo en los comienzos, es improbable que pueda obtenerlo con sus obras literarias. A este contratiempo, Connolly le suma que, en la época en que le toca escribir, se necesita más dinero que en las anteriores; existen, igualmente, sustitutos remunerativos más acordes a la pluma que la escritura literaria: el periodismo, la crítica, la publicidad, el cine, etc. Por un lado, la necesidad; por el otro, las tentaciones, que se prestan a una satisfacción menos laboriosa, en detrimento de la obra, de la obra capaz de perdurar.

Connolly irá, a lo largo de los capítulos de esta segunda parte, analizando y advirtiendo sobre los 'enemigos de la promesa': los medios y decisiones inadecuados que pueden malograr al escritor, aun dotado de talento. Por ejemplo, en el afán de obtener dinero, es muy probable que caiga en el exceso de producción, o que se termine adaptando a las exigencias de un público masivo para incrementar las ventas en desmedro de su propia visión y gusto. La enseñanza tiene sus pros y contras, aunque no es una opción que salga del todo mal librada: permite largas vacaciones y no invade la imaginación creativa; pero no cualquiera disfruta haciéndolo (parece el caso de Connolly) y es un trabajo que no se presta demasiado a la ampliación de la experiencia $^{71}$. La administración pública le parece una ocupación estática, árida y parasitaria, y no cree que nadie que sobreviva en ese elemento pueda tener imaginación. El trabajo publicitario es tan semejante a la composición lírica que puede terminar ocupando toda la creatividad, o tergiversarla. El negocio familiar parece ser la mejor salida.

Estas consideraciones conducen al axioma que las rige: "Un trabajo externo es perjudicial para el escritor en la proporción en que se aproxima a su vocación" (2005: 152): la crítica, la publicidad, el periodismo, el cine o las conferencias exigen del

\footnotetext{
${ }^{71}$ Para Connolly, los mejores entre los escritores-profesores tenían amplias relaciones extralaborales.
} 
escritor una cuota de creatividad que va en detrimento de su literatura. Cuando aparece un nuevo talento, se le abalanzan estas propuestas; necesitado de dinero, es probable que ceda. Las exigencias de los editores pueden cumplir el mismo papel. Una vez atrapado, menoscabado por el trabajo, buscarán un talento de reemplazo.

En el apartado anterior Connolly menciona el periodismo como al pasar para ocuparse luego de él en extenso, dado que se trata de la tentación mayor que acecha a los escritores de su momento; lo considera la actividad más mortífera para la salud literaria. Periodismo y literatura, si bien comparten el uso de la palabra como materia prima, tienen una diferencia de textura. El primero está escrito para entregarse de inmediato, debe ser simple y efectivo; como está escrito para que se lea una vez, en su carácter efímero, difícilmente pueda leerse dos veces. Por su misma participación en la actualidad, queda excluido del mañana, de lo perdurable: "Nada envejece tan rápido como la candente actualidad, y en el periodismo no hay nada más valioso que ella" (2005: 155). La literatura, formal y compacta, participa de un tempo lento, de una laboriosa entrega, que hace a su relectura y su perdurabilidad. El escritor entregado al periodismo convierte la ligereza en un hábito, y la paga y lectura inmediata se convierten en un hábito cómodo. El ensayo de cierta extensión, meditado y laborioso, se ha visto en la época de Connolly erradicado de los periódicos, y queda reservado a revistas especializadas; la brevedad, importantísima para la prensa, es enemiga del ensayo literario; y es así que son muy contados los artículos que resisten la relectura ${ }^{72}$.

Existen, sin embargo, tres clases de escritores a los que el periodismo puede ayudar en su momento: los aficionados, que, no acostumbrados a tener público, y por tanto a pensar en él, son palabreros y oscuros; los escritores bien provistos pero perezosos, que sólo pueden revelar sus tesoros en artículos breves de pago inmediato (el caso del mismo Connolly, algo irónicamente tratado); los escritores con un estilo literario tan parecido al periodístico que pueden hacer la transición de un tempo al otro sin esfuerzo (es el caso de Forster, Strachey y Hemingway); aunque siempre se corre el riesgo de que ambos estilos terminen confundiéndose, en desmedro de la literatura.

Connolly cita a Somerset Maugham, que detecta otro mal para el escritor en la labor periodística: su exigencia de impersonalidad. El escritor habituado al periodismo

\footnotetext{
72 "Un artículo es chisme. Un ensayo es reflexión y visión interior. Un artículo tiene la ventaja temporaria que le otorga el calor social; un tema caliente aquí y ahora. El calor de un ensayo es interior. Un artículo es oportuno, actual, está vinculado a los asuntos y las personalidades del momento; lo más probable es que se vuelva añejo al cabo de un mes. [...] Un artículo y su fecha de nacimiento están unidos como hermanos siameses. Un ensayo desafía su propia fecha de nacimiento, y también la nuestra" (Ozick 1112).
} 
tiende a perder la facultad de expresar su propio punto de vista, ve los hechos desde un punto de vista generalizado, con afán de objetividad. Por más bien escrito que eso esté, va en detrimento de la visión parcial pero anclada en la personalidad del escritor y su particular estilo.

Y, como este es el caso que le atañe, y en el que Connolly se piensa y analiza, pasa a la primera persona, previniendo a un ficticio autor joven, de cierto éxito y talento (Walter Shelleyblake), que se ha visto tentado de aumentar sus ingresos con la crítica periodística: "Yo mismo soy una persona perezosa, irresoluta, demasiado vana y modesta en exceso, insegura de sus juicios e incapaz de terminar lo que he comenzado, y me he aprovechado del periodismo" (2005: 159); sin embargo, le aconseja que cualquier otra forma de ganar dinero le sería más provechosa, que la crítica es un trabajo de jornada completa con sueldo de media, y que gasta lo mejor de su ingenio en la mediocridad de otros. Tampoco encontrará tiempo para su escritura y lecturas privadas, porque no querrá leer una vez terminada la jornada de trabajo. Sus textos tienen una supervivencia efímera. A no ser que sea un Hazlitt, Arnold o Sainte-Beuve, ganará poco dinero, perderá tiempo, escribirá insustancialmente y ocupará un lugar incómodo en el campo literario. Si, después de todo, debe dedicarse al periodismo, podría escuchar algunos consejos: "que nunca tenga que criticar un libro malo, que jamás critique más de uno a la vez" (2005: 160), que no escriba nada que no pueda reimprimirse, es decir, que no tenga valor más allá de su mera actualidad; que no escriba sobre nada que no le interese y que tenga siempre algo en claro: su trabajo no es para nada indispensable.

Otra de las tentaciones a las que el escritor se ve sometido, con más o menos apremio según las épocas, es la política; su incumbencia puede llegar a ser necesaria dentro de la tarea del escritor, pero debe aprender la mejor manera de ejercerla, a riesgo de perder de vista sus objetivos. Connolly escribe este libro en la inminencia de la Segunda Guerra Mundial, por lo que considera que el escritor debe ser político para integrarse y lo debe seguir siendo para protegerse; se trata de una cuestión de vida o muerte, progreso o reacción, democracia o fascismo, en la que los segundos términos se configuran como enemigos del arte. El momento adecuado para que el escritor se comprometa políticamente es justo ese, el de la crisis, cuando todavía puede conseguir algo; una vez que se toman las armas y se instala la guerra, la elocuencia del artista pierde en gran medida su capacidad de influir en los hechos.

Sin embargo, la política entraña riesgos que el escritor que se aboca a ella pocas veces evita. Se trata de un trabajo a tiempo completo, con reuniones, panfletos y 
proclamas que consumen mucha energía -además de no constituir el mejor medio para la sensibilidad creadora-, y es muy posible que haya gente mejor preparada para hacerlo. Se corre también el peligro de entregarse a las seducciones de la oratoria, un arte más tosco que la escritura, que sustituye la integridad de la pluma por las artimañas de la persuasión. Además, los hábitos políticos suelen desdeñar los esfuerzos que exige un arte difícil y esquivo, y la clásica enemistad entre el hombre de acción y el de pensamiento, las armas y las letras, vuelve a aparecer, inconclusa, recurrente.

Según Connolly, los mejores usos que un escritor puede dar a sus armas en la política son, en primer lugar, la sátira, con el poder que conlleva de poner en ridículo al enemigo; luego, si es inteligente, puede ayudar con su capacidad analítica a colegas más activos; finalmente, puede prestar su colaboración al idealismo, sin el cual cualquier movimiento fracasa.

Entre los peligros que el escritor, ya decidido a participar, debe evitar, están: la propaganda, o el uso de material político no asimilado, que introduce en "la forma un nivel inferior de artificio, el del panfleto o el folleto, y una fusión imperfecta con el proceso creativo" (2005: $168 \mathrm{n}$ ); debe ser meticuloso con su vocabulario, porque la literatura política está saturada de clichés, con palabras y frases desgastadas por el abuso de la oratoria. Igualmente, debe usarlas con máxima responsabilidad, dado que esta literatura no sólo se ocupa de palabras, sino de palabras que afectan a vidas humanas y, por tanto, se convierte en un arma que sólo deberían utilizar los debidamente cualificados. De manera que, si no está seguro de poder asimilar las contrariedades que la vida política entraña, es mejor para el escritor pasar de largo; el valor de la experiencia política para el arte de un escritor es indirecto, y, una vez que ha pasado el tiempo en que esas acciones fueron decisivas, no suelen ser las más recordables de la vida de un artista.

El siguiente peligro que Connolly decide tratar es el de "escapismo", aunque hace la salvedad de que esta actitud en sí misma no es ni buena ni mala; se puede escapar tanto de un campo de concentración como de las propias responsabilidades; puede uno expatriarse para cortar lazos nocivos y encontrarse consigo mismo como puede ser un adicto a los viajes que busca perderse en el desplazamiento. El único delito es huir del propio talento, abortar la maduración del germen de lo que la obra podría ser. En ese momento de crisis preguerra el escritor debe decidir qué es lo mejor para la producción de su obra, si permanecer o retirarse. 
Otras actitudes o hábitos escapistas son el alcohol y las drogas, que Connolly ve como síntomas del olvido de sí, una manera de ahogar la capacidad desperdiciada. Más insidiosas le parecen la ensoñación y la conversación, formas inferiores de la actividad creativa, que agotan en sí mismas los modos y temas que deberían constituir la obra. Puede también huirse de las exigencias del arte a través del culto a la nobleza o la pertenencia exclusiva a cualquier grupo donde la literatura carece de importancia. Caso aparte es el de la religión, dado que "la fe religiosa implica la rendición del intelecto pero no de la sensibilidad" (2005: 179) y, por tanto, ciertos talentos pueden desarrollarse adecuadamente bajo su órbita; sin embargo, no la aconseja para los intelectuales, dado que el dogma tiende a acabar con la capacidad inquisitiva.

Las aficiones que pueden desviar al escritor de la ejecución de su obra son muchas; más allá de ellas, Connolly intenta indagar el porqué de la huida; entre los escapistas descubre un rasgo en común: todos han sido prometedores. “iLa promesa! Palabra fatal, mitad soborno y mitad amenaza, [...] hasta que el significado se expande y la carga del juramento bajo el que crecimos se convierte en la carga de la expectativa que nunca podemos satisfacer”. El círculo de los conocidos acusará a quien prometía, aguardando su suicidio ritual. "A quien los dioses desean destruir primero lo llaman prometedor" (2005: 180-181). Para reencontrarse con su vocación y poder desarrollarla plenamente el escritor debe liberarse de la carga que representa la satisfacción de los deseos ajenos.

El escapismo puede ser temporario, un momento de crisis, o convertirse en el lugar de la defección. En el fondo, siempre hay indolencia, esa pereza, síntoma de conflicto interior, que imposibilita al artista para hacer lo que más desea; en este caso, puede ser también síntoma de un alto grado de perfeccionismo, que en su conflictiva exigencia siempre conlleva una indolencia dolorosa, casi patológica.

Pasa luego Connolly a analizar el problema del sexo con respecto a la creación. Por un lado, analiza los beneficios y limitaciones de la elección homosexual. Según él, esta actitud le impide al escritor cierto conocimiento cabal de las mujeres, que se traduce en posibles dificultades para plasmarlas en su obra; no tanto en la crítica y la poesía, donde en un nivel intenso y sublimado las pasiones se vuelven generales, sino en la narrativa y el drama. Se corre el riesgo de presentar a las mujeres como peores o mejores de lo que son, o en todo caso, se acierta en tipos maternales o fraternales. El noviazgo, el matrimonio, los hijos, el adulterio, temas esenciales en la vida de muchas personas, pueden llegar a ser tratados con un conocimiento imperfecto. Por otro lado, el método 
proustiano de transformar personajes en esencia masculinos en muchachas de ficción, no le parece verosímil, dado que muestra su incongruencia y se convierte en una falla artística. No cree que el dilema planteado tenga solución alguna, más que evitar en la obra las situaciones que requieran de la creación de ese tipo de caracteres; y hace aquí una salvedad que parece importante: por lo menos, "hasta que podamos cambiar la sociedad" (2005: 186). Sin entrar en detalles de un tema tan ampliamente estudiado, este comentario de Connolly se ha vuelto un poco anacrónico -como él mismo acaso intuyó que sucedería- ya que las relaciones homosexuales, con sus particularidades, ya no son temas por ocultar o sublimar, sino que tienen amplia representación y circulación dentro de la literatura; si bien perfectible, nuestra realidad, en ese sentido, es muy otra.

El peligro opuesto lo representa la vida familiar. "La dificultad inicial estriba en que el escritor sensible es incapaz de vivir solo" (2005: 186); esta incapacidad conduce al matrimonio, el matrimonio a los hijos, y ambos a la necesidad de ganar cada vez más dinero; para hacerlo es muy posible que el artista deba trabajar en algo que, además de no interesarle, le quitará el tiempo y la energía necesarios para la creación.

Si el homosexual se ve en dificultades para representar una parte de la vida que Connolly considera que llevan la mayoría de los seres humanos, a cambio está libre de las limitaciones de esa vida. Con cierto grado de idealización, cree que disponen de ingresos suficientes, tiempos para viejos y nuevos amigos, viajes y, al llegar a la madurez, libre de responsabilidades y vínculos, la independencia que les permitirá la total y feliz entrega al arte (piensa en Gide, en Henry James). El éxito literario parece estar del lado del escritor sin hijos; su crianza lleva tiempo, y pueden compensar en el escritor el deseo de inmortalidad que subyace a la obra. Además, la felicidad doméstica suele ir en contra de la fertilidad creativa. La recomendación final sería evitar el matrimonio y la paternidad a joven edad.

El siguiente, y último, 'enemigo de la promesa' que Connolly analiza es el éxito. Considera que puede ser de tres tipos distintos: social, profesional o popular. El éxito social fue el más buscado en un pasado reciente, que Connolly considera perdido, dado que la sociedad elegante ya no es culta, ni gusta de mantener artistas y salones. Por un lado, se trata de una sociedad bastante insensible, que se aburre fácilmente, y el artista puede acabar ocupando el lugar de bufón, además de ambicionar valores y posesiones que no son los suyos, con el consiguiente esfuerzo y frustración; es cierto también que se trata de un mundo cerrado, y el artista queda privado así de una vida más amplia que podría utilizar como material para su obra. Por otro, es beneficiosa para cierto tipo de 
artistas, que encuentran en ella su material a la vez que su público, y cuyo talento es apropiado para florecer ahí; Connolly piensa en Alexander Pope, Henry James y Proust, en Congreve y en Wilde.

El éxito profesional, el reconocimiento de los colegas artistas, de los artistas en ciernes y la crítica especializada, es un auténtico placer. Siempre existen muchos jueces de la buena literatura, que saben reconocer el talento por inusual que sea, a la vez que conceden a las obras maestras del pasado una apreciación independiente de la moda. Aquí no es difícil entrever que Connolly habla de sí mismo, de la función que cumple dentro del campo literario el crítico independiente, su papel en la consolidación y formación del valor literario; cuidadores del talento, que celebran la calidad al margen de la moda, erigiéndose en guardianes del gusto; este es el tema que voy a profundizar en el capítulo siguiente. No parece que en este caso Connolly tenga mucho que criticar, más allá de que este éxito es doloroso porque genera la envidia de los artistas fracasados.

En cambio, cree que el éxito popular es fatal. Compara al éxito con una escalera móvil que, cuando el artista sube en ella, tiene mucha dificultad para bajar; de alguna manera, tanto si escribe bien como mal, sigue subiendo, a base de distintos estímulos. El que tiene don de gentes, no se recobra de su éxito, y adquiere un sentido de misión que lo lleva a tratar de complacer siempre a su público. Los que llegan a través del éxito político pueden sufrir algún revés, y recuperarse. El que sólo divierte, no recibe críticas, y no tiene más que seguir divirtiendo. El escritor de éxito popular debería bajarse de esa escalera y someter cuanto escribe a un tribunal supremo crítico; es decir, a la tradición: “¿Divertiría a Horacio, Milton, Swift o Leopardi? ¿Podría leerlo Flaubert? ¿Lo elegiría el Gusano Infalible, el paladar exigente de los muertos?" (2005: 199).

Cada admirador que un escritor consiga por cualquier medio que no sea la calidad legítima de su arte, tarde o temprano, se le anota como un punto en contra, una posible hostilidad futura. El escritor debería rechazar toda publicidad que no esté basada en la calidad de su obra, y no prestar su nombre a otras causas. A su vez, Connolly afirma que el fracaso es tan peligroso como el éxito; en caso de poder, elegir este último.

En el último apartado de esta segunda parte Connolly intenta un resumen, a la vez que trata de establecer algunos consejos positivos para los escritores de su época. Éstos deben buscar entre las formas disponibles en la tradición y darles una nueva perfección. La novela, género dominante en el campo literario de su época, y de la 
actual, puede ser aún un campo fértil; como las malas no duran, no vale la pena sino intentar escribir una que se cuente entre las mejores. Considera que no es una forma adecuada a los escritores jóvenes; la construcción de un libro largo requiere de mucha energía, y las novelas de los principiantes suelen comenzar bien y se van deteriorando con el correr de las páginas. La observación imparcial de la gente como realmente es requiere distanciamiento y experiencia, un artista vuelto máquina de observación, bien integrado en la realidad.

Por su parte, el cuento es una forma más adecuada para ellos, evita la rutina y es una forma fluida y experimental; lo mismo pasa con la novela corta, una forma desatendida donde se pueden alcanzar ejemplos de perfección formal. El teatro parece adecuado a los jóvenes por su longitud, y sus dificultades técnicas se pueden resolver con buenos consejos. El artículo largo le parece que tiene futuro, sobre todo en la forma del ensayo crítico; pero no vale la pena escribir artículos que no puedan reimprimirse.

La historia literaria demuestra que la poesía lírica desafía el tiempo más que cualquier otro género. Connolly considera que su práctica sigue teniendo vigencia, pero nadie después de Eliot puede desconocer la extrema dificultad de escribir buena poesía. Ésta debe ser de una destilación tal que sea más profunda que la prosa; el escritor debe mantener un alto nivel de sensibilidad e integridad, dar cuidado y trascendencia a todos los niveles del verso, de lo contrario, los lectores buscarán lo poético en los relatos y novelas, de más fácil acceso. El amplísimo espectro de temas y materiales, como la libertad que se le concede al poeta para elegirlos, compensa la tiranía de la forma.

Si bien la novela autobiográfica, para Connolly, llegó a un punto de no retorno con En busca del tiempo perdido, sí ve posibilidades al género autobiográfico, siempre que esté pensado y escrito con las intenciones estéticas del arte.

Escribir "bien" depende de cada escritor, es una cuestión de salud literaria. Si no escribe tan bien como le gustaría, o tan a menudo como quisiera, debe examinarse. El material de un escritor es su vida espiritual, en amplio sentido, y él es responsable de su custodia y desarrollo; es muy probable que ésta entre en conflicto con las realidades de su tiempo, pero el escritor debe crear la forma de mantenerla en óptimo estado de salud. Una vez establecida esta posición, y si el talento recibe la nutrición adecuada, el aquejado escritor se cuestionará otras fuentes de la felicidad creativa: la salud, el sexo y el dinero.

La salud de un escritor no debe ser demasiado buena, por lo menos mientras está escribiendo. Un cuerpo vigoroso es contrario a la cultura, exige alivio físico o acción 
directa para liberar su energía desbordante. Excepto en vacaciones, un autor no debe tener más salud que su público, no debe sentirse tan bien que se le nieguen la lectura y la meditación. La preocupación sexual es un sustituto de la creación artística; pero el escritor debe pensar en la mujer no como la inspiradora de su arte sino como consecuencia de éste, dado que, mientras esté trabajando bien, poseerá el atractivo y la confianza en sí de cualquier objeto que cumple con su función. Después de la creación, para vivir el éxito o el fracaso, el amor resulta esencial. El otro elemento fundamental es la solvencia: si pasa muchas dificultades económicas sólo podrá trabajar durante lapsos breves, y si tiene demasiado dinero, a no ser que siempre lo haya tenido, agotará su inspiración en gastarlo. Todo escritor, antes de comenzar un período creativo, debe procurarse un trabajo del que pueda obtener un ingreso suficiente con el mínimo esfuerzo.

La tercera parte del libro desarrolla la autobiografía intelectual y emocional del joven Connolly, el futuro crítico, sus años de formación. Más allá de lo animada y diversa que ésta pueda ser, me detendré en los sucesos y reflexiones de mayor relevancia para establecer los ideales estéticos y vitales de Connolly; una vez hecho esto, podré analizar la funcionalidad de un texto de estas características dentro de un ensayo de crítica literaria.

Cyril Conolly nació el 10 de septiembre de 1903, en Coventry, donde su padre cumplía funciones en el ejército regular. Su abuelo también había sido militar, e hijo de militares; "los Connolly eran una raza frugal, de ojos azules, larga vida, tranquila, pulcra y obstinada, de soldados y marinos" (2005: 226). Su abuela Kemble era hija de hacendados que, trasladados a Londres, hicieron fortuna en el comercio del té. Esa fortuna se disipó entre once hijos y la restauración de una abadía; un mal recuerdo que amargaba a su nieto por las oportunidades perdidas. En 1900, en una visita del ejército a Irlanda, su padre conoció a su madre y se casó con ella; era hija de Edward Vernon, doctor en letras y juez de paz; una familia señorial que poseía el castillo de Clontarf; eran una raza fogosa de conquistadores, orgullosos de su ascendencia anglonormanda.

Poco después envían al padre de Connolly a Sudáfrica, donde se traslada con su familia. Los recuerdos de Cyril se vuelven exóticos: las fresias silvestres, los duraznos aplastados, los camaleones y lagartos del jardín, las mascotas, el mar; el pequeño hijo único vive en algo parecido al éxtasis, dedicado a la aprehensión de la belleza visual. Estuvo dos veces en Sudáfrica, a los cinco y seis años; en el intervalo fue a Irlanda, 
donde hizo vida de castillo, intensificando su amor a lo bello y generando una nueva pasión: el esnobismo.

En 1910 se marcha definitivamente de Sudáfrica con una institutriz, mientras sus padres se quedan; "por entonces era un esteta" (2005: 231). De paso por Córcega, para visitar a una tía, descubre la amistad y se enamora de un niño polaco, Zenón; “desde entonces casi nunca me ha faltado el sentimiento amoroso [...]. He tendido a considerar esa condición como la justificación de la existencia, que tiene prioridad sobre todas las ideologías" (2005: 232). De paso por Tánger se enamora de un moro barbudo.

Tenía casi siete años, y afirma que desde ese momento su carácter comenzó a deteriorarse: su abuela lo malcrió. Recuerda ser un niño mimado, y que sus peores defectos se remontan a ese período: indecisión, ingratitud, pereza, impaciencia, crueldad, cólera. A diferencia de los amores anteriores, éste se trata de uno no correspondido: no quiere a su abuela, y se aprovecha de ella.

En la escuela era popular, porque se había embarcado en la carrera que ocuparía gran parte de sus energías, la de tratar de ser divertido. No es bueno en los deportes, pero comienza a interesarse por los estudios y recibe premios; lee mucho. Adquiere allí también otro conocimiento: la abuela tiene una economía modesta, si no pobre, y viven en casas rentadas de clase media. De niño descubre una escisión que lo condicionaría: "Inglaterra = la abuela, pensiones, escuela, pobreza, clase media. Irlanda = tía Mab, castillos, vacaciones, riqueza, clase alta” (2005: 238). Esta distinción un tanto irreal cobra gran importancia para el pequeño Connolly, hijo único sin hogar, solitario, inseguro y, por demás, un híbrido social. No es de una clase ni de otra; se siente de una pero es condicionado por la otra.

Entre tanto, llega su madre para liberarlo de una escuela donde se la pasaba enfermo y se lo lleva con ella a Irlanda; allí se interesa en las antiguas tradiciones del país. Lo irlandés le parece de una aristocracia natural y provinciana, menos esnob que lo inglés. Mientras, ante la avalancha de parientes, defiende su timidez e inseguridad haciéndose el gracioso; se siente humorista por las mañanas y sentimental por las noches. Cree que su vida no tiene sentido porque no posee títulos de nobleza. Sus sentimientos son románticos y literarios, y se fijan en esa Irlanda que representaba la brillantez y el lujo; otro amor no correspondido: algo juvenil y temprano, en su madurez dice que no hay nada que lo enfurezca más que ser tratado como irlandés.

Sus padres eligen una nueva escuela privada en la costa, donde se siente desgraciado y llora noche tras noche; se pregunta si esas escuelas merecen el dinero que 
se paga por ellas o las lágrimas que los niños derraman. Desgarradoras despedidas y largas separaciones socavan el amor de los niños abandonados por sus padres, aun antes del período natural de conflicto. Sin embargo, Saint Wulfric's era una escuela bien dirigida que al final le hizo bien, y cumplió su objetivo de prepararlo para entrar en Eton. Un establecimiento típico inglés, donde se adoraba el éxito político o social, con una educación espartana y estoica, donde por sobre todo se privilegiaba el carácter. Estalla la Primera Guerra. Connolly simpatiza con un par de profesores. Cambia de personalidad: cuida su aspecto, practica deportes y se convierte en una pieza de exhibición: "el irlandés alegre, generoso y rebelde" (2005: 251).

En Saint Wulfric's Connolly hizo dos importantes amigos: George Orwell y Cecil Beaton. "Mi rebeldía era teatral, pero la de Orwell iba en serio" (2005: 252); un chico que parecía haber nacido viejo, alto, taciturno, incapaz de cortejar, pero con la rara singularidad de pensar por sí mismo, ser un intelectual y no un loro. Daban largos paseos juntos, escribían poesía, se criticaban. A diferencia de Connolly, no era un romántico; rechazaba la escuela, la guerra, el imperio y se mostraba indiferente a las alabanzas tanto como a los castigos. Orwell le demuestra a Connolly que existe una alternativa al carácter: la inteligencia; Beaton le demuestra otra: la sensibilidad. Éste era un chico encantador, de excelentes modales y soñadores ojos azules de largas pestañas. "De Orwell aprendí literatura y de Cecil arte" (2005: 254).

Por aquel entonces la poesía les significaba la escapada romántica, fragmentos crepusculares, exceso emocional, noche e infelices lágrimas. Y Connolly sintetiza así lo que ve como el centro de esta búsqueda:

Como se ve, el hilo conductor de esta autobiografía es un análisis del romanticismo, ese romanticismo en decadencia bajo cuya sombra crecimos. Llamaría romanticismo al rechazo a enfrentarse con ciertas verdades sobre el mundo y nosotros mismos, así como a las consecuencias de esa negativa. Es un rechazo que puede ser espléndido y necesario, esta pretensión de que la belleza es verdad y la verdad belleza, que el amor es más fuerte que la muerte, el alma inmortal y el cuerpo divino, pero en los cien años transcurridos desde el resurgimiento romántico lo hemos tenido en exceso. (2005: 259)

Este sentimiento romántico acaba siendo una confesión de cobardía e inmadurez. Y si sólo algunos vivían en el mundo de la poesía romántica, todos lo hacían en el mundo del amor romántico: exagerado, sacrificial, que moría con la reciprocidad. Connolly se enamora de varios compañeros ${ }^{73}$, e imagina ensoñadamente a sus compañeras. Para él

\footnotetext{
${ }^{73}$ Un tratamiento más extenso merecería la singularidad de las relaciones homosexuales en los colegios ingleses, que han recibido amplia atención en su literatura. Connolly se ocupa de ellas y, más allá de la
} 
esta intensidad en la necesidad de compartir su vida con otro está asociada a su condición de hijo único; desgraciadamente, para el romántico la afinidad se da no por comunidad de intereses sino por la belleza.

El chistoso Connolly, de agudas réplicas, consigue una beca para Eton. Ya su posición, de la que tantas veces volverá a quejarse, está signada: la del intelectual al que nunca le dan el trabajo porque es brillante pero poco firme (2005: 268). Acepta la teoría de que el carácter es más importante que el intelecto, que el intelecto sin carácter lleva a la perdición, y que la mejor combinación es carácter más hermosura. Él, como está lejos de ser hermoso, se empeña en ser encantador. Antes de partir hacia Eton pasa las vacaciones de 1917 en Irlanda: lo más importante de ese período es que se compra una bicicleta con la que empieza a hacer excursiones; se trata del primer acceso de la pasión viajera que lo acompañaría de por vida. Hasta entonces dice conocer todo por los libros, es por eso que su padre y el capellán de Saint Wulfric's lo previenen del tipo de tentaciones y acosos homosexuales que va a encontrar en Eton, sobre todo porque su carácter literario lo hace proclive a "toda clase de tonterías venenosas" (2005: 272), le dicen.

Si bien Connolly ingresa en Eton con la posición privilegiada de ser uno de los sesenta becarios del rey, su posición cambia de ser el mayor de una escuela a ser el menor de otra. Se siente como un griego culto vendido en un mercado de esclavos, porque los alumnos de los primeros cursos se ven obligados a realizar tareas serviles para los mayores, y algunos de éstos están facultados para azotar con varas. La variedad de jerarquías, maneras, vestimentas, privilegios y demás particularidades que Eton ha ido acumulando a lo largo de los siglos son enormes y complejas, y no es mi intención reproducirlas aquí, pero desconocer su existencia y la importancia que tienen en la formación de los alumnos sería errado para interpretar sus consecuencias en el carácter de Connolly. Ante su propia soledad y el sistema de torturas de los alumnos mayores y servilismo de los menores, se refugia en la biblioteca, y descubre el crepúsculo celta. Comienza a librarse de los golpes a costa de ingenio y de sarcasmo; para salvarse se burla de las víctimas, y por tanto se convierte en un matón igual a los demás. Se enamora de un chico que lo maltrata. Desaliñado, cobarde en los deportes, perezoso para el trabajo, impopular entre los profesores, recibe un informe negativo. Sus padres

constante vigilancia y algún castigo que reciben de parte de los preceptores, asegura que en su caso eran inocentes, platónicas. 
se enfadan y la culpa recae sobre Orwell, aunque ahora apenas se ven, separados sentimentalmente como realista contra romántico.

Pasados los primeros años se encuentra en la situación de no ser siervo ni amo, sino que forma parte de la burguesía media del colegio. Se enamora de otro compañero, pero aun a esa edad no conoce el contacto físico: "Nunca me habían besado siquiera y el amor era un ideal basado en el exhibicionismo del hijo único, respondía al deseo de depositar mi personalidad a los pies de alguien" (2005: 289). A diferencia de Orwell con su non serviam, Connolly posee las ambiguas dotes del mimetismo y tiene por eso éxito en la escuela; entra a la sociedad literaria y escribe poemas y críticas. Adopta la pose de dandi melancólico, con un toque de Wilde, que vuelve su vida más interesante pero a su vez más teatral y egocéntrica. Traduce a los clásicos, y sus libros de cabecera son Victorianos eminentes de Strachey, Gibbon y La Rochefoucauld. Son los tiempos de finales de la Primera Guerra, y Connolly, que se considera un liberal de izquierda, propone algunas reformas de las costumbres más reaccionarias de Eton; recibe algunos azotes como represalia. En carta a un amigo describe si situación: "Ahora creo que no hay nada que no pueda hacer, aunque son muy pocas las cosas que merecen el esfuerzo" y traza uno de sus planes: "[...] creo vivir por la mejor forma de felicidad: aprender a apreciar lo que es de primera clase y distinguir el fraude, aprender a buscar la belleza en todo [...]. Publicar todo el material bueno que me sea posible" (2005: 301). Predica entre sus compañeros sus firmes convicciones de esteta. En un momento, lo que revela su método y su afán, se dice: “"Es un gran cuadro y tiene que gustarme, he de aprender cómo lograrlo', hasta que, ayudado por mi propio buen gusto, lo consiga" (2005: 305). Se propone ser estoico en la adversidad y epicúreo en la prosperidad, para alcanzar no la perfección que antes creyó el sentido de la vida, sino la perfección en la felicidad. Es el verano de 1921 y viaja con su padre a París; su primer viaje al extranjero si no contamos su estancia sudafricana de la niñez. La ciudad lo asusta; es conducido a un burdel donde toma un champagne que no puede pagar; tiene miedo. Cumple los dieciocho sin haber besado a una chica.

Para Connolly uno de los mayores defectos de Eton es la impopularidad del trabajo: los chicos sólo desean la popularidad, y el trabajo es poco elegante. Hasta entre los becarios estudiar demasiado está mal visto, "tras lo que se encuentra la desconfianza del intelecto que caracteriza a los ingleses y su prejuicio a favor del aficionado" (2005: 324). Desde su más temprana infancia hasta esta primera juventud Connolly recibió la misma lección: ser intelectual es ser diferente: uno quedaba excluido, como enemigo o 
servidor, de las clases dirigentes; la inteligencia, como contraria a la habilidad, se considera un obstáculo para la vida. Con pocas excepciones, los alumnos desprecian a los profesores, dado que no son caballeros. Se limitan a recibir una enseñanza común, que aprueban a duras penas. Pero existía también una cultura interna a la que accedían algunos favorecidos, "la pura tradición dieciochesca etoniana de humanismo clásico que no podía aprenderse en ningún otro lugar” (2005: 325): la Antología griega, Homero y Virgilio eran los pilares de esta educación interna, pero estos clásicos estaban "romantizados" tanto en sus traducciones como en sus interpretaciones.

La homosexualidad era un ingrediente de esa cultura clásica, pero sólo se daba por sentada. Por lo demás, más allá del esteticismo como culto de la belleza, Eton, como todas las escuelas públicas, no tenía ninguna solución para el problema del sexo. Los alumnos que iban más allá del platonismo eran expulsados una vez descubiertos; la escuela no podía hacer nada por ellos. Con prudencia y eufemismos el capellán predicaba contra las prácticas de Wilde; los profesores célibes, la continencia. Esteticismo y puritanismo, clásicos romantizados, el sentimentalismo celta contenido por el buen gusto clásico, son estas las tensiones estéticas y morales de trascendental importancia en la formación de Connolly como ensayista.

Al terminar sus estudios sabía de memoria mucha literatura de varias civilizaciones, en especial griega, latina, francesa e inglesa: Homero y la Antología; Catulo, Horacio y Virgilio, Petronio, San Agustín y Marcial; Montaigne, Villon, Racine, Verlaine y Mallarmé; Spenser, Marlowe y Shakespeare, Milton, Tennyson y Arnold, Housman, Yeats, Browne, Boswell, Gibbon y Sterne. Una característica del comedimiento clásico de Eton era que tuvieran tal conocimiento de las obras maestras del pasado pero no enseñaran absolutamente nada de las creaciones contemporáneas.

En el último año tiene todos los privilegios de los mayores, es elegido miembro del selectísimo club que dirige Eton y es popular, gana el premio de historia. Su figura señera es Petronio, el ocioso brillante: “Otros habían alcanzado la grandeza mediante el sudor de su frente, pero Petronio logró la fama a pesar de su ociosidad" (2005: 340). Connolly trabaja de noche y dedica los días a la relación social. Pasa unas exitosas vacaciones de esquí en Suiza con su madre. Decide que se preparará para obtener una beca y estudiar historia medieval en Oxford, en especial las herejías cristianas. Lee todo Gibbon bajo la ilícita luz de la vela: "como les ocurre a tantos perezosos, una vez que empezaba a trabajar no podía detenerme. Tal vez por ese motivo evitábamos el trabajo" (2005: 348). 
Rinde los exámenes para optar por la beca, y la obtiene. Su éxito no puede ser mayor. Por Pascuas viaja a Francia con un amigo; es la primera vez que sale sin sus padres. Llega a Aviñón, la ciudad de los papas que tan bien conocía por los libros; pero más importante fue su conocimiento del Mediterráneo, que llegará a formar la cuna de su civilización, una referencia constante en su vida, sus viajes y obras; lo recorre hasta llegar a Cataluña.

Cuando regresa su tutor le quita una revista francesa subida de tono, el Tristram Shandy de Sterne y un volumen de Rabelais. Connolly sucumbe al éxito social y al esteticismo, descuidando, y no por primera vez, su soledad artística: es un miembro modélico del club de Eton, con esmoquin y sombrero de paja; lee Mario el epicúreo de Pater, À rebours de Huysmans, Aristipo, y los primeros libros de Huxley, Baudelaire y Mallarmé. Su educación lo había preparado para escribir en lenguas clásicas y muertas, no ve la manera de escribir bien en inglés, e intenta con el francés. Detesta todo lo público y obligatorio, sólo le interesa charlar con sus amigos, viajar, leer libros antiguos y entregarse a controversias del pasado; su cobardía moral le impide trabar amistad con el grupo artístico, donde se encuentran Harold Acton, Anthony Powell y Henry Green; en su pose de dandi hastiado y aburrido detesta la historia, porque triunfa en ella, y se dedica al estudio de los clásicos. Atribuye gran parte de su infelicidad al espíritu competitivo: "No competirás jamás" es su nuevo lema. En esta época de pleno triunfo, a punto de irse al Balliol College de Oxford, un compañero le dice: "Bueno, ya tienes una beca de Balliol y perteneces al club... ¿Sabes? No me sorprendería en absoluto que no hicieras nada más durante el resto de tu vida" (2005: 375). Estas palabras, y el pautado y monótono futuro que le auguran, lo llevan a formular su "teoría de la adolescencia permanente":

La teoría de que las experiencias vividas por los muchachos en las grandes escuelas públicas, sus glorias y decepciones, son tan intensas que dominan sus vidas y detienen su desarrollo. El resultado es que la mayoría de la clase dominante permanece adolescente, con mentalidad escolar, cohibida, cobarde, sentimental y, en último análisis, homosexual. Los laureles tempranos pesan como plomo, y de muchos de aquellos chicos que conocí en Eton podría decir que ahora están acabados. Quienes los conocieron entonces los vieron en su mejor y más brillante época. Ahora, al principio de la treintena, son ruinas habitadas por fantasmas. (2005: 375-376)

Connolly culpa al romanticismo, con su apetencia de muerte, que hace hincapié en la infancia: una gracia cuya pérdida no compensa ninguna doctrina. Crecer es entonces una pura pérdida, un obstáculo muy difícil de superar. "Puesto que era incapaz de 
escribir en ninguna lengua viva, cuando salí de Eton ya iba en camino de convertirme en crítico" (2005: 378), tarea para la que considera que posee una buena base; luego la falta de empleo lo lleva hacia ella. En realidad, ambicionaba ser poeta, pero sólo podría haber imitado tradiciones perimidas; cuando Eliot y Valéry acuden a salvar a su generación del dragón romántico, éste ya lo había devorado, nos dice Connolly (2005: 378).

Ante este análisis pesimista, derrotista, imagina lo que la "Voz de Eton" le respondería: otros han obtenido éxitos más rutilantes que los suyos, y eso no los arruinó. El gran mundo es como Eton: enseña sus valores, pero no puede dar un empleo; brinda los rudimentos del arte, enseña lo que se puede esperar de la vida, una educación clásica que consiste en modales externos y equilibrio interno; esto confiere las infrecuentes virtudes del buen juicio y el buen gusto. Las lenguas clásicas han demostrado no ser un impedimento para la composición inglesa. El problema es que Connolly es demasiado perezoso; nunca aprendió la más importante lección, la de concentrarse en una sola tarea, y le falta carácter.

Aquí concluye Connolly su autobiografía:

He concluido en este punto porque señala el fin de mi absorción inconsciente de ideas, aparte de que ya no podía sucederme nada nuevo. [...] En algún punto de los hechos que he narrado se ocultan las causas de esa pereza que me ha incapacitado, en algún lugar yace el pecado cuya culpa está a mi puerta, incrementado por interés compuesto más rápidamente que la promesa (pues la promesa es culpabilidad, la promesa es capacidad de decepcionar a la gente), y a través de ellos esas ideas y falacias románticas, esos errores de juicio contra los que debe medirse la validez de mi crítica. (2005: 384-385)

Visto el fracaso que, según sus expectativas, y las de aquellos que aguardaban que la promesa se cumpliera, significó su primera novela, Connolly se interroga por escrito sobre los materiales y condiciones de la creación de una obra maestra, o por lo menos de un libro que dure diez años en un mundo tan convulsionado como el de fines de la década del treinta. Su amplio conocimiento de la tradición le permite calibrar lo que, desde los gustos y búsquedas estéticas que su formación y personalidad han instalado en él, cree pros y contras de los estilos vistos en sus grados de oposición. Mandarines y modernos; románticos y clásicos; como en muchos otros ensayos Connolly, recurre al método de la oposición binaria para aclarar y sistematizar sus hipótesis. Así, en fin, selecciona y valora -tareas de la crítica por excelencia- lo mejor de cada uno de ellos y denuncia lo peor. Pero lo que en realidad busca es una síntesis superadora de su propio conflicto, porque a lo largo del libro aún puede verse cómo Connolly ejerce sus facultades críticas pensándose como escritor, buscando la falla en la ejecución de su 
pasada obra y estableciendo los marcos que posibilitarán su obra futura. Es por esto que las primeras dos partes del libro -crítica de los estilos y crítica de los hábitos- se ven complementadas y resignificadas por la tercera parte, la autobiografía de formación del crítico-artista. La tensión, el conflicto que Connolly intenta develar, y tal vez resolver, en cuanto al arte, se encuentra en sí mismo, en su familia y en su formación, escenificado en las dos ramas de su familia y en los clásicos romantizados de su educación georgiana; como se verá también en su próximo libro, intenta llegar a una síntesis, con vías de posibilidad, de un artista de la forma cuya íntima educación sentimental es romántica.

Por otro lado, si el saber del arte y los estilos es experiencia de la tradición, Connolly también se interroga por las condiciones sociales, morales y sentimentales que posibilitan la experiencia de la creación. Si en cuanto a estilo de escritura Connolly cree estar bastante seguro sobre lo que debe hacerse, en cuanto a estilo de vida está más seguro de lo que no se debe hacer. Porque en última instancia está realizando una crítica a su experiencia personal, corporal, en tanto individuo de reconocidos talentos pero que, por razones que intenta determinar, no le han servido para ser el escritor que se esperaba que fuera. De ahí que busca su falla, cuáles han sido los enemigos culpables de esa promesa todavía trunca; se interroga sobre la pereza, el infantilismo, el sentimentalismo, que en concreto no le permiten llevar la vida que anhela, la vida de creador, y lo limitan a la de crítico como escritor fracasado. Y digo 'limitan' porque así es como Connolly vivió su oficio; más allá de su éxito profesional, siempre lo sintió como un fracaso artístico.

Familia y educación, como voy a analizar en el próximo capítulo, determinan sus valoraciones y gustos, y para Connolly también determinan los defectos de carácter y voluntad que le impiden la obra. La familia aristocrática irlandesa, con sus castillos y su romanticismo celta, languidez y permanencia; la abuela inglesa de clase media, que lo malcría y se somete fácilmente al carácter caprichoso del niño; la tensión, el dualismo de no pertenecer en verdad a una verdadera clase social; el colegio, donde el ambicioso Connolly consigue éxitos tempranos, una victoria pírrica, dado que consisten en los logros rituales de una sociedad cerrada, infantil y egoísta, que desdeña el trabajo y la intelectualidad y aplaude el carácter, los deportes y el dandismo. Connolly encuentra en estas características de su temprana formación las posibles causas de su indolencia, de la pereza que le ha impedido adquirir los hábitos del trabajo y la ambición que requieren el arte y la vida adulta. Es por eso que formula, con las críticas pertinentes, "la teoría de la 
adolescencia permanente"; sin embargo, en la ironía final, parece reírse un poco de su actitud autocompasiva, quejosa, poniendo en vilo los anteriores argumentos; puede al fin que esa educación sólo haya acrecentado ciertos defectos innatos de su carácter. Algunos rasgos de éste y su próximo libro parecen muy cercanos a El crack-up, de Francis Scott Fitzgerald, donde el autor busca en su pasado personal y en las características de su época la grieta, las fallas que lo llevaron al desastre presente. También pueden verse allí el romanticismo juvenil, la fijación en los éxitos y fracasos escolares, el no-crecer, la perduración de la situación infantil, la debilidad del carácter (y, en su caso particular, los riesgos del matrimonio y el éxito). La diferencia es que en el caso de Fitzgerald el derrumbe es posterior al reconocido logro artístico de la obra, pero en el caso de Connolly el deseo y la imposibilidad de la obra son la obra misma. Autoacusación y autocompasión, más autofiguración, son constantes vertebradoras de la obra de Connolly, sumadas al ejercicio de la crítica. En sus ensayos y artículos no dejó de buscarse a sí mismo, y a las causas que le hicieron fracasar como escritor; o más bien, por qué era un no-escritor, por qué se (le) negaba ese deseo que tan esencial le parecía. Y en tanto crítico se pone en el lugar del artista, porque es lo que él quería ser; rastrea sus fallas y aciertos, sugiere algunas soluciones ${ }^{74}$, tanto pegado a la letra como al estilo de vida y la condición moral, el habitus.

A riesgo de que la cita sea extensa, me parece clave incluir las intenciones que tuvo Connolly para incluir su autobiografía de formación como tercera y última parte de un libro de crítica literaria:

Lo cierto es que entre la última sección y las anteriores existe una armonía que, si no resulta evidente, es en todo caso intencionada, la misma relación que existe entre un texto y sus ilustraciones. Así, varios escritores que aparecen como nombres de manual de literatura en la primera parte reaparecen en la tercera como personas de carne y hueso, y las teorías literarias mencionadas en la primera parte reaparecen en la tercera, donde queda patente que tienen su origen en la existencia misma. El romanticismo se juzga de acuerdo con una educación romántica y la autobiografía es básicamente de ideas, dejando ex profeso de lado todos los episodios de mi vida que no han tenido una intervención directa en la formación de las especulaciones literarias en las que se basa la primera parte. (2005: 32)

Por su parte, en cuanto al estilo en que está escrita esta parte autobiográfica, Connolly comenta que tiene como objetivo ilustrar el examen de la prosa contemporánea y la sugerencia de soluciones hechos en la primera parte. Intenta escribirla en una prosa que

\footnotetext{
74 "La única crítica que puede tener algún alcance, consiste en ponerse en el lugar del que ha realizado obra de creador y en mostrar, desde este punto de vista, las imperfecciones del trabajo y sobre todo en sugerir lo que hubiera sido necesario hacer" (Payot 239).
} 
combine la rapidez coloquial con una elasticidad que permita incursiones en la prosa poética del estilo mandarín. Por tanto, el texto autobiográfico quiere cumplir la doble función de mostrar cómo lo que parecen abstractas elucubraciones literarias son en realidad teorías encarnadas, frutos de la educación social y sentimental que determinaron los gustos del crítico, y a su vez se propone como ejemplo estilístico de los resultados de dichas elucubraciones.

Así, lo importante en esta obra de Connolly no es su autobiografía como parte del género en sí, porque no es esa su funcionalidad primaria; y, si bien intenta una síntesis ejemplar, tampoco es revolucionaria su retórica autobiográfica. Lo más destacable es el uso autobiográfico: justificar sus posiciones críticas, mostrándonos su fundamento, y a la vez ponerlas en práctica. El ensayo que se vuelve autobiografía; la autobiografía que ensaya las lecturas y emociones que forman al crítico y encarnan así sus teorías. Si, como dice Piglia, "la crítica es la forma moderna de la autobiografia" (Piglia 2005: 141), en tanto el ensayista escribe su vida cuando cree escribir sus lecturas, en el caso de Connolly también podemos decir que su autobiografía se convierte en parte esencial de su crítica literaria, y que hace patente la funcionalidad de escribir su vida para dar cuerpo a las teorías en acto que son sus lecturas. Corre el velo que pesa sobre la abstracción teórica porque, como dice Giordano, "cuando el ensayista nos remite [...] a su propia vida, asistimos a un desenmascaramiento: en lugar de ocultarla (exigencia que el saber se impone), el discurso del ensayo muestra, como espectáculo y también como objeto de conocimiento, la subjetividad que lo enuncia" (Giordano 2005: 243).

\subsection{La tumba inquieta, 1945. (The Unquiet Grave)}

La tumba inquieta es un libro sapiencial, y aún más íntimo que el anterior. Escrito durante la Segunda Guerra Mundial, y publicado cerca de su fin, da testimonio nostálgico de un mundo que se acaba, y del que Connolly es figura ejemplar: un humanismo europeo, culto y refinado, que profesa el amor de lo bello, y que acabo de describir la influencia que tuvo en la formación del autor. Entre los moralistas franceses y los ensayistas ingleses, entre los artistas de uno y otro país (no en vano casi la mitad del texto está escrito en francés), el autor construye un libro fragmentario con citas, reflexiones, entradas de diarios, epigramas, que armonizan para crear la imagen de Connolly como hombre de letras, y la del artista que quiso ser y con qué materiales pensó construirlo. 
Ya la primera, y famosa frase, ahonda, más que revelar, porque es la misma búsqueda que Connolly emprendió en su libro anterior, en las preocupaciones que el crítico, aún pensándose autor, intenta resolver: "Cuantos más libros leemos, antes nos damos cuenta de que la verdadera misión de un escritor es crear una obra maestra, y que ninguna otra tarea tiene la menor importancia" (2005: 403). Por tanto sigue en búsqueda esencial de lo literario en tanto arte capaz de perdurar, una pregunta de la crítica por excelencia. Todas las demás ocupaciones y tareas que al arte se parecen pero que no lo son (periodismo, radio, cine, y hasta la misma crítica) están destinadas a la decepción. El escritor debe pensar, sentir y escribir bien, y procurarse todos los medios genuinos para lograrlo. Para indagar en la escritura de la obra maestra establece los modelos, patrones de los cuales extraer su enseñanza; luego de dar su lista (obras de Horacio, Virgilio, Villon, Montaigne, La Rochefoucauld, Rimbaud, Byron) nos dice que un catálogo así revela mucho de su autor. ¿Qué tienen en común?

Aman la vida y la naturaleza; no creen en la idea de progreso; se interesan por la humanidad, a la vez que la desprecian. Todos son lo que sus críticos han llamado a Palinuro [Connolly]: “¡Materialista!”. Sin embargo, todos son más adultos y menos románticos que él. [...]En lo que respecta al sentimiento, estas obras maestras contienen el máximo de emoción compatible con un sentido clásico de la forma. (Connolly 2005: 404-405)

Se vuelve a ver el problema de la síntesis estilística que antes se planteó en Enemigos: emoción romántica y perfección clásica, especulación sobre el hombre y preocupación estilística. Si la esencia de la literatura no existe, y por tanto no puede ser extraída y verbalizada; si las condiciones para producir una obra maestra no pueden determinarse con exactitud; sí existen estas obras y quienes las escribieron, y están ahí para que el crítico en tanto escritor, el escritor en tanto crítico, aprendan a trabajar a partir de ellas.

La tumba inquieta es un libro fragmentario, escrito durante un año de crisis (Connolly está separándose de su esposa Jean Bakewell, cumple cuarenta años y su carrera de escritor no se consolida, no pudo todavía terminar un trabajo de ficción que satisfaga sus ambiciones, etc.); extractos de diarios, reflexiones, dudas, citas donde el autor intenta desvelar el obstáculo para su creatividad, indagar sobre las causas del fracaso, aunque no es mucho en lo que Connolly ha fracasado, pero el tema en sí se cristaliza como propio de su obra y personaje. La obra se presenta como "un ciclo de palabras en tres o cuatro ritmos: el arte, el amor, la naturaleza, la religión” (2005: 406), relato de una experiencia de crisis y experiencia misma de la crisis de la escritura. 
Si el libro anterior era un estructurado ensayo en busca de un estilo de escritura perdurable, una advertencia sobre los posibles enemigos del escritor, y la ejemplar escritura de la autobiografía del crítico, dando cuenta del dónde y el porqué de las ideas antes expresadas, este libro se presenta como escritura en sí, la escritura más o menos inmediata de una experiencia de crisis y de búsqueda; crisis personal del autor y crisis del mundo y los ideales en que el autor se formó, dado que el germen de este libro fue escrito en forma parecida a la de un diario durante los años 1943 y 1944, en plena Segunda Guerra Mundial. Por tanto, en el análisis de este libro, estableceré dos movimientos que, en su conjunción, dan a la obra su originalidad, a la vez que la ligan con la tradición europea antes desarrollada; por un lado, tenemos la escritura de sí, la autofiguración ensayística, y por otro, el armado de un libro ensayístico a través de una escritura fragmentaria.

Recordemos los sucesos que nos ponen ante la escritura de este libro. Una vez fuera de la Universidad, después de algunos viajes, y ya habiendo ganado cierto lugar en el mundo de las letras a través de sus primeros artículos, el prometedor Connolly escribe al fin su novela, The Rock Pool (1936), materializando su fantasma de escritura. La novela no satisface los estándares estéticos del autor ni los de la crítica relevante. Emprende entonces su búsqueda de una escritura y un tipo de obra que puedan sobrevivir el mero suceso, capaz de perdurar en el tiempo; la posible fórmula de una obra maestra, y de cuáles son, o mejor dicho, no son, las circunstancias favorables para crearla, sin dejar de rastrear su propia falla en el intento; así escribe Enemigos de la promesa (1938). El estallido de la Segunda Guerra y algunos intentos infructuosos de escritura, a los que se suma en grado preponderante una crisis amorosa, parecen dejar en ruinas el mundo del autor, sus anhelos de escritura y su propia personalidad. Así es como emprende la escritura de este libro; escritura de las ruinas, que luego serán obra; búsqueda de sí, que al fin conforma en la escritura una figura de sí; escritura del fin de Occidente, que es reescritura y continuación viva de esa tradición; escritura de la crisis que luego será la salvación a través de la escritura. Paradójicamente, los mayores logros de Connolly son su propio personaje (perezoso, erudito, talentoso, francófilo, gastrónomo, bibliófilo, dandi, viajero, amante de los lémures), al que fue creando en la medida en que se buscaba, y la búsqueda incesante de la obra maestra a través de la escritura de críticas y libros; conforman al fin sus obras maestras. Como dije anteriormente del ensayo en tanto género, el logro no es el resultado, el hallazgo, sino la escritura del interrogante, los trazos de la búsqueda. 
A lo largo de toda su obra Connolly escribió sobre sí mismo; fuere el que fuere el tema principal de su escritura, siempre se lo vislumbra a través del personaje, patente en el texto, del escritor. Este compromiso con su imagen parece provenir, como en el caso de Montaigne, de un escepticismo en el conocimiento de sí; entonces, la escritura se convierte en un espacio, una instancia, especular, donde plasmar los vislumbres de la propia imagen y a la vez darle forma; siempre mediando la estética, dado que la instancia de publicación se encuentra en el mismo nacimiento de la escritura, y por tanto es una escritura de sí para otros.

Muchas partes de La tumba parecen sapienciales, sentenciosas reflexiones sobre el amor, la religión o el arte; pero en ningún caso se trata de lecciones; atesoran un momento de la escritura -en muchos casos, se puede encontrar más adelante una sentencia en que contradice a la primera-, se trata de ensayos; no tratan de decir la cosa en sí, sino las maneras o capacidades de quien escribe para entrar en determinada relación con ella. Esta relación, al darse en momentos distintos, se configura de distinta manera; en este sentido, las contradicciones o diferencias, pueden ser vistas no como fallas sino como riquezas, matices. La escritura renuncia a la coherencia interna, la del objeto acabado, cerrado sobre sí mismo, para captar con mayor fidelidad al sujeto de la figuración, complejo, imperfecto original que cambia incesantemente. Así, vemos que en el proyecto mismo de escritura se encuentra la búsqueda de sí mediante procesos de autofiguración, la construcción de una imagen de autor. Pero al hacerlo a través del ensayo, no se trata del autorretrato de un personaje que progresa en conocimiento y experiencia para llegar a un punto; es un personaje, pero no el de una novela; no tiene pasado, o éste se mira siempre desde un presente distinto; es un personaje que se construye en el momento, en el devenir de la escritura; sus cambios son inherentes a la escritura y sus circunstancias, pero no se interpretan en clave evolutiva, sino que conservan la diversidad del original. Si bien me explayaré sobre el tema más adelante, es importante decir que la forma elegida en este caso es la que mejor se presta a realizar estas intenciones: la creación del personaje no sigue su devenir cronológico, ni está sujeta a la lógica progresiva, cohesiva del texto argumentativo. Se trata de la escritura por fragmentos, que elaboran el presente de su escritura y, por tanto, del autor en ese momento, y se significan al fin por su yuxtaposición y no por su evolución en el tratamiento. La escritura de la introspección en su momento de suceso se presta así a la plasmación del sujeto cambiante, en constante devenir, a diferencia del personaje típico de las memorias, autobiografías o novelas. Es cierto que entre los procesos de 
autofiguración que se utilizan en el ensayo interviene la imaginación, en tanto el yo se conforma también a través de sus posibilidades o proyecciones; a título de ejemplo: "Mis anteriores encarnaciones: un melón, una langosta, un lémur, una botella de vino, Aristipo. Épocas en las que he vivido: la era augusta en Roma, luego en París y Londres de 1660 a 1740, y, por último, de 1770 a 1850" (2005: 413); pero, a diferencia de los otros géneros, renuncia a la exigencia diacrónica $\mathrm{y}$, por tanto, a la unificación psicológica y cronológica, problematizando desde otra estructura la diversidad del sujeto en cuestión.

Para dejar constancia de ese proceso de introspección y sus disímiles hallazgos, el ensayista renuncia, en cierto modo, a la composición del personaje a la manera tradicional; no muestra al fin la totalidad de una individualidad, los resultados de su introspección, sino el proceso mismo; introversión y extroversión se dan simultáneamente; el ensayarse termina siendo el ensayo mismo: "cada acto de autoconocimiento habrá de estar acompañado de un acto de escritura que lo registre [...] Autoconsciencia y expresión avanzan solidariamente" (Navarro Reyes 172). Para poder llevar a cabo estos procesos, es necesario romper por lo menos con dos dificultades: primero, la de poder hablar de uno mismo, que es pensarse a sí mismo en la palabra; después, lo que es más difícil, romper el prejuicio interno, "romper los lazos afectivos que nos atan a nuestras debilidades, desvelar el propio interior con la objetividad y precisión de un cirujano. Hay que estudiarse y hablar de sí como si uno fuese otro" (173). (En este sentido es importante notar el uso del seudónimo Palinuro con el que Connolly firma su libro como una forma de distanciarse, un mecanismo textual que ayuda a un mecanismo psicológico). Porque de lo que se trata no es de construir una figura ejemplar, un héroe épico, siempre igual a sí, sino un hombre en toda su complejidad. Y dado que en el caso de Connolly se trata a menudo de buscar la falla, las ocultas razones que le impiden cumplir sus deseos, habla a menudo bastante mal de sí, o 'confiesa' demasiados defectos. Hablando de su molicie, obesidad y pereza, por ejemplo, cita a Brillat-Savarin: "L'obésité nuit à la beautè en détruisant l'harmonie de proportion primitivement établie. [...] Proposer à des obèses de se lever le matin, c'est leur percer le coeur",75, para luego aportar sus reflexiones: "Dentro de cada hombre gordo hay uno delgado que gesticula violentamente para que le dejen salir. Una persona

\footnotetext{
${ }^{75}$ Facilito aquí la traducción de Ricardo Baeza“'La obesidad perjudica la belleza destruyendo la armonía de proporciones primitivamente establecida. [...] Proponer a los obesos levantarse temprano es atravesarles el corazón" (Connolly 1949: 90).
} 
perezosa, con independencia del talento con que cuente inicialmente, se habrá condenado a ideas de segunda mano y amistades de segunda clase" (Connolly 2005: 471). El talentoso que ha arruinado su carrera por la desidia y el amor al placer, y por tanto ha hecho una obra de segunda, objeción de cierta crítica, más allá de su atención a la verdad, no deja de ser lo que Connolly dice de sí mismo; de lo contrario serían defectos poco serios para hacer sobre la obra de un autor. Es por eso que muchos que han escrito sobre sus obras cometen el error de criticar en Connolly lo que en realidad él se ha criticado, creen criticar al autor cuando en realidad critican al personaje que Connolly nos construyó en sus textos; no hacen la crítica del texto y sus procesos ${ }^{76}$; decir que Connolly es un fracasado es como decir que Montaigne tenía problemas de memoria. La veracidad de las afirmaciones no está sujeta a su adecuación objetiva, sino que debemos poner el énfasis en su fidelidad subjetiva; eso que está expresado es lo que el autor pensaba en el momento de escribirlo, así "el último valor del texto no es comprobable más que apelando a esa experiencia interna e intransferible de sí mismo" (Navarro Reyes 175); no se trata del ente cartesiano, abstracto en tanto razón, sino de un pensamiento con cuerpo, un yo concreto que, hable de lo que hable, no habla más que de sí.

Así también, cuando habla de otros autores, dentro del contexto de esta forma de ensayo, el autor habla de sí. Casi la mitad de La tumba está compuesta por citas directas de autores, casi todos franceses (Montaigne, Chamfort, Sainte-Beuve, Baudelaire), en su lengua original. Pero su inclusión no se debe a que se vaya a efectuar un análisis de dicho autor ni, como en el caso de los tratados científicos, como cita de autoridad para respaldar un dicho propio; Connolly habla de sí mismo a través de los fragmentos que elige. Se trata al sujeto de conocimiento de manera oblicua, y así, también, se busca sortear las dificultades de hablar de sí y de hacerlo con la misma objetividad que si se tratara de otro: Sainte-Beuve, sobre la tragedia de Chamfort, dice: " que era un moralista cuyas credenciales nunca fueron aceptadas del todo, que hay demasiado egoísmo en sus juicios (que refleja desprecio lleno de culpa que sienten hacia sí mismos aquellos que saben que están desperdiciando su talento debido a la pereza y el hedonismo)" (Connolly 2005: 493). Es obvio que se trata de una crítica que el ensayista se hace de interpósita manera. Así, paradójicamente, una obra que no tiene otro propósito que hablar de sí, no cesa de referirse a la obra, las anécdotas, los lugares, las reflexiones, de

\footnotetext{
${ }^{76}$ Pueden verse algunos ejemplos citados en la Introducción a esta tesis.
} 
otros autores; en esto, como en muchos aspectos que no analizaré, Connolly sigue de cerca el ejemplo de Montaigne, que también fue acusado de ser un recolector de citas y sólo aportar los textos que las unen. Entonces, por un lado, tenemos la cita como manera oblicua de enfrentar las dificultades del análisis personal, pero por otro lado tenemos la apertura a la otredad, el reconocimiento de los propios límites del sujeto que conoce. La posibilidad de comprobar en otros los mismos defectos, anhelos y virtudes, le permiten al ensayista objetivarse en esa relación con lo humano en tanto compartido, y no es que el autor se compare con los autores citados, sino que se identifica con ellos, más allá de su estatura:

Intensa emoción, una mezcla de alivio y desesperación, al leer el cuaderno de SainteBeuve Mes Poisons y descubrir: "Este soy yo". Este elegíaco, como le gustaba considerarse, que citaba como propios mis versos favoritos de la poesía latina, y que creía que la felicidad era leer a Tibulo en el campo "avec une femme qu'on aime", que se llamaba a sí mismo "le dernier des délicats", [...] menor como hombre que sus contemporáneos románticos, aunque mejor artista que ellos [...]. iQué emocionante escuchar una voz así del pasado que resulta una inspiración en el presente! (2005: 471-472)

Aquí podemos ver cómo la descripción y el elogio de Sainte-Beuve le sirven al ensayista para verse en él, y para decir oblicuamente cosas de sí mismo que de otra manera parecerían pedantes o embarazosas. A su vez, el encontrar a alguien en tal sentido parecido, le da una potencialidad a su destino crítico; esto le permite también al escritor pensarse en tanto posibilidad, más allá de la forma incidental de su devenir en el tiempo; se piensa a través del otro, pero también se imagina distinto. Porque en el pensamiento de sí no encuentra sólo lo que es, y ya ha sido, sino lo que pudiera ser; en el momento de pensarse también se encuentra el anhelo, la posibilidad del cambio, la diferencia; dado que, sobre todo en el caso de este libro, se recorre una crisis, y se intenta salir de ella, busca la forma de la salvación ${ }^{77}$. Así, al interrogarse sobre sus obras maestras, se mira en tanto posible escritor de alguna, y entrevé la distinción: "Le gustaría haber escrito Les Fleurs du Mal o la Saison en Enfer sin ser Rimbaud ni Baudelaire, sin su sufrimiento intelectual y sin estar enfermo ni ser pobre (Connolly 2005: 404-405)".

Vemos aquí entonces la doble función especular del ensayo: el texto es espejo del yo que se crea a sí mismo en la escritura, pero es también la trama de un sujeto que se objetiva al mirarse en otros, los que han sido, de alguna manera, como él, y por tanto le

\footnotetext{
${ }^{77}$ Que como veremos se dará en la escritura misma del libro.
} 
ofrecen las posibilidades de lo que podrá ser; el sujeto que deviene ve como posible lo que ya fue, en tanto ha sido posible y está terminado. Además, eso que fueron otros, ha demostrado la veracidad de su supervivencia, en tanto es lo que el ensayista ha leído, y le sigue pareciendo válido. Esto nos abre el camino para otra función de la cita.

Connolly se encuentra al momento de escribir y componer este libro en una doble crisis: una crisis personal, en tanto escritor y amante, y una crisis cultural, en cuanto europeo. La Segunda Guerra Mundial pone a Europa en una situación límite, y es difícil en ese momento vislumbrar cómo podrá superarse. Apenas pasaron treinta años desde que finalizara la Primera Guerra; los grandes esfuerzos que se hicieron por superarla, que dan lugar a un renacimiento de la cultura y el arte europeos -las vanguardias, las obras de Joyce, Proust, Eliot, la belle époque-, se ven de pronto interrumpidos, puestos a prueba por el afianzamiento de los totalitarismos nazifascistas; a una guerra le sucede en muy poco tiempo otra, más cruel de lo imaginable. El desesperanzado análisis de Oswald Spengler en La decadencia de Occidente (19181923) parece cumplirse como una profecía inobjetable. Aparenta ser el fin de un antiquísimo mundo, de la cultura del humanismo europeo que esbocé en el primer capítulo; los horrores, las atrocidades de la guerra y el genocidio son la contracara brutal y terminante de la fe en el hombre y la razón, de la tradición y sus valores. Es por eso que, en estos momentos, como Montaigne citaba a sus clásicos latinos, Connolly se aferra a sus clásicos franceses, entre los que aquel se encuentra. Se trata de volver la vista atrás, a los modelos y las lecturas formadoras, en busca de establecer la continuidad de una tradición y una cultura ante una peligrosa decadencia que la amenaza. Connolly siempre admiró y amó la literatura y la vida francesas, y gran parte de sus ideales y emociones estaban asentados allí; ese amor impregna el libro de voces, lugares, recuerdos; una elegía por un mundo que siente perder, y que tiene a Francia por capital. Esa es la razón con la que Connolly, en un prólogo escrito en 1950 con motivo de la reedición de La tumba, se defiende de las críticas, que manifestaban que el libro sólo era una antología de fragmentos de un esnobismo extranjerizante:

Aparte de su amor por Francia, Palinuro también deseaba proclamar su fe en la unidad y la continuidad de la cultura occidental en su hora de crisis. Eligió sus citas para demostrar que llevamos pensando de la misma manera desde los días de la Antigua Grecia, que el pasado siempre puede arrojar luz sobre el presente. Buscaba confirmaciones más que originalidad. (Connolly 2005: 392)

En ese momento Connolly es muy consciente de estar separado de Francia; por eso al escribir sus "diarios", los gérmenes de este libro, evoca los placeres de esos lugares, 
para recordar que habían sido escenarios de altas formas de civilización, para establecer la afinidad con esa cultura, y lo necesarias que fueron y eran sus ideas y cultura. La cita, que le permite a Connolly verse y escribirse a través de otros modelos, que le hablan de sí pero también de sus posibilidades, también cumple esta otra función: vuelve a inscribir, reafirma, copia lo que está por desaparecer; en esos tiempos apocalípticos, Connolly escribe esta elegía para su Europa agonizante: "Aun así, vivir una decadencia no nos debe hacer desesperar; es sólo un problema técnico adicional que el artista debe resolver" (2005: 467). Es en este sentido, además de otros analizados, que de alguna manera se siente el último hombre de letras. Escribir estas cosas, que a primera vista parecen tan poco comprometidas, por contraste, no oculta que "La tumba inquieta es inevitablemente un libro de la guerra" (2005: 391); cumple su función de otra manera, una defensa de la cultura en su continuidad: salvaguardar la tradición es lo que siente como tarea del hombre de letras; como en su momento dijera Eliot ante los bombardeos alemanes en Londres: "Sigamos traduciendo a Virgilio".

Otro tema que me ocupa al analizar esta obra de Connolly es el de su fragmentarismo. El mismo autor dice en su "Introducción" que se le ha reprochado que el libro no sea más que una antología de citas selectas. Además, como queda puntualizado en mi Introducción, los distintos críticos que se ocupan de la obra, tanto los que la califican positiva como negativamente, poco hacen por resolver o clarificar cuál es el propósito de la forma tan peculiar de este libro. Por un lado, podría pensarse que el carácter fragmentario se debe a que la obra tuvo su germen como diario, y los diarios se encargan de plasmar momentos o reflexiones extáticas de una sucesión diaria, donde la continuidad y el desarrollo profuso de los temas es de escasa relevancia. Por otro, podría verse en esta fragmentación un análogo a nivel formal de la destrucción y la crisis a la que se ve sometida Europa y el propio autor, y este es un rasgo que comenzó a manifestarse en todas las artes de vanguardia de entreguerras.

Si en Enemigos de la promesa se da un paso original, novedoso, en cuanto a lo que formalmente un ensayo de crítica literaria puede ser -comienza como un análisis bastante detallado de los estilos de la prosa inglesa y termina con la autobiografía de formación del crítico-, dando a la obra un carácter problemático en cuanto a su unidad, en La tumba inquieta, la ejecución, trasunto de una idea sobre el ideal de la obra, enfrenta otra crisis formal sobre la concepción de la "obra” en general. Según Philippe Lacoue-Labarthe y Jean-Luc Nancy, en su libro El absoluto literario, que se ocupa de la 
teoría de la literatura del romanticismo alemán, “el fragmento es, en efecto, el género romántico por excelencia" (80). Esto, que podría verse como la decantación estética de las tendencias, más que opuestas diría en tensión, que Connolly analizó en Enemigos, y cuya importancia en su formación y sus crisis creativas acabamos de precisar, vuelve a ligar más bien su práctica a la más pura tradición del género. Como señalan los autores, el género del fragmento no es una invención del romanticismo de Jena; a Friedrich Schlegel se le revela su uso a través de la publicación en 1795 de los Pensamientos, máximas y anécdotas, de Chamfort. $\mathrm{Y}$ a partir de aquí trazan una escueta pero clarificadora genealogía del género: Chamfort remite a las Máximas de La Rochefoucauld, y éstas a su vez a los Pensamientos de Pascal, ligados a su vez a la obra paradigmática que funda el género para la modernidad, los Ensayos de Montaigne. Los autores caracterizan al género mediante tres rasgos, muy útiles para clarificar el uso del fragmento que Connolly hace en su libro, y ligarlo a la tradición ensayística:

su relativo inacabamiento ("ensayo") o la ausencia de desarrollo discursivo ("pensamiento") de cada una de sus piezas; la variedad y la mezcla de los objetos sobre los que puede tratar un mismo conjunto de piezas; la unidad del conjunto, en cambio, constituida de alguna manera fuera de la obra, en el sujeto que en ella se muestra o en el juicio que en ella transmite sus máximas. (81)

El fragmento, en su inacabamiento, participa del carácter del ensayo. Pero no debe confundirse el fragmento con el pedazo suelto, mero residuo de un conjunto mayor. Es una exposición que no aspira a la exhaustividad y se corresponde a la moderna idea de que lo inacabado puede ser publicado, o que lo publicado nunca está acabado (86). Si por un lado no es sólo un pedazo, por otro no está cerrado sobre sí mismo, a la manera de otros términos genéricos utilizados por los moralistas: nota, máxima, pensamiento. Mientras que en estos casos se trata de trozos acabados, el inacabamiento es esencial al fragmento, en tanto es la proyección inmediata de algo que sin embarga nunca acaba. Si bien en su constitución formal resalta el carácter de individuación, dado que parece algo independiente de lo que lo sucede y antecede, lo hace en tanto indicador de un proceso y no de un estado, un devenir no un ser.

Otra de las cualidades que los autores resaltan en el uso de esta forma es su falta de sistematicidad. Podría pensarse que hay en Connolly una incapacidad para practicar una exposición de ese tipo, pero hemos visto cómo en otras composiciones, sin embargo, elige a modo expositivo el uso de la oposición dual, para luego llegar a una síntesis o, por lo menos, objetivar una tensión; si bien no estamos ante tratados argumentativos de rigurosa formalidad, se expone de una manera bastante clara, 
ordenada y lógica (aunque el último capítulo de Enemigos ya muestra una rebelión estructural por su manera de resignificar el libro todo). Pero en este caso la falta de tal sistematicidad es el fundamento subyacente a la exposición, dado que lo que falta es el principio que pone orden a las razones. Pero el fragmento, si no es sistemático, es orgánico; no avanza hacia ningún fin o conclusión ni tiene tampoco centro, "la totalidad fragmentaria no puede estar situada en ningún punto: se encuentra simultáneamente en el todo y en cada parte" (88). Se trata de una totalidad plural que no compone un todo a la manera de ser un objeto pero sí un conjunto, que replica el todo en cada uno de sus fragmentos. Lo orgánico, la totalidad, no es la suma de las partes, que darían un resultado, sino su conjunción, su co-presencia. La incapacidad de la Obra, la obra maestra por la que Connolly se desvela, en tanto absoluto, muestra su imposibilidad fundamental en el inacabamiento ${ }^{78}$; en este sentido, "la obra está ausente de las obras, y la fragmentación siempre es también el signo de esa ausencia” (93). Connolly realiza su obra al escribir siempre su imposibilidad de escribirla, la obra es los contornos de la Obra, de centro vacía; es por eso un escritor de la no-escritura. "Cuantos más libros leemos, antes nos damos cuenta de que la verdadera misión de un escritor es crear una obra maestra, y que ninguna otra tarea tiene la menor importancia" (Connolly 2005: 403), esta famosa declaración de principios, que cité poco más arriba, parece contradecir su misma afirmación, dado que el autor está escribiendo sobre la obra maestra, y por tanto parece no estar realizándola. "Pese a esta evidencia, ¡cuán pocos escritores lo admitirán, o, habiéndolo admitido, estarán dispuestos a abandonar la pieza de iridiscente mediocridad que han comenzado!" (2005: 403), declara a continuación; pero él no deja de escribir, en esa aspiración a un absoluto imposible; escribe en torno a la Obra, de otra forma.

Por tanto, en el fragmento, en su inacabamiento esencial, se traza el contorno de la Obra ausente; y se consuma en su forma una pérdida de lo indiviso, del individuo como un objeto igual a sí mismo. En la búsqueda de la Obra, en el modo que tiene de cuestionarse sobre su posibilidad, abandona o suprime, aun sin quererlo, la ejecución de la Obra misma, mutando hacia otro tipo de obra, "obra de la ausencia de la obra" (Blanchot, citado en Lacoue-Labarthe 110). Una búsqueda de la obra que, en tanto objeto, es obra:

\footnotetext{
${ }^{78}$ Una obra que, en otro género, ilustra este mismo principio es Las posibilidades del no, de Luis Chitarroni.
} 
El fragmento figura [...] el fuera de obra esencial a la obra, más esencial a la obra que la obra misma. Funciona como exergo, en los dos sentidos del verbo griego exergazômai: se inscribe fuera de la obra, y la realiza. Lejos de poner en juego la dispersión o el estallido de la obra, el fragmento romántico inscribe su pluralidad como exergo de la obra total, infinita. (95)

Búsqueda y realización, en su inacabamiento, el fragmento no es una ruina, un pedazo de algo que una vez fue, sino un proyecto, un germen, que mira al futuro, hacia las condiciones de una obra posible. Fijación de un devenir, objeto finito de un movimiento infinito, se trata de una unidad discursiva que pone en cuestión los ideales representativos de la narración y la argumentación. En el caso de La tumba, los fragmentos siempre se presentan como proyectos $-\mathrm{y}$ veremos cómo el autor se queja de haber sido malinterpretado-: de la actualidad de la crisis a la posibilidad de salvación; pero ese movimiento es la obra, no el resultado que queda por fuera de ella. He ahí la contradicción aparente de este tipo de obra: tiende hacia un objeto (objetivo), pero finalmente el mismo "tender hacia" es el objeto, y el anterior queda por fuera y es indiferente a la obra. Como unión de contrarios es también que el fragmento, objeto de arte en sí mismo, es, sin embargo, la expresión del sujeto artista; sugiere la posibilidad, el proyecto, de una identidad donde la diferencia entre el artista y la obra queda abolida. Esa fantasía "es sostenida por la identidad de la forma de arte - de la forma como producto de una fabricación- y de la forma de vida, de la forma como presentación del movimiento de la vida" (Rancière 82). La obra en tanto tal no se presenta entonces como algo fuera del sujeto que la realiza, como en la figura del hijo -algo que ha salido del cuerpo y es diferente de él-; el fragmento restituye al sujeto de la subjetividad el poder creador y crítico del arte en tanto obra. Ésta carece de finalidad exterior y es la actualización del sujeto que escribe, "de un sujeto a partir de ahora calificado como sujeto del arte" (Lacoue-Labarthe 464). El artista en busca de la obra, de las potencialidades de la obra en sí mismo mientras escribe, es la Obra de Connolly. El Sujeto-Obra, sin embargo, poco importa la identidad que guarde con Cyril Connolly: se trata de un Personaje que nada le debe a la "imitación" de lo real, es el autor en su obra mientras la escribe.

El fragmento, aun en la búsqueda de su posibilidad, es una crítica de la obra. Pero este tipo de crítica se manifiesta en la caracterización del crítico, porque lo que la obra es o debería ser, la idea de la obra, sus características, no pueden no ser, en el fondo, parte de las características del crítico, manifestaciones de su individualidad, de su originalidad. Y si bien el tipo de crítica que ejercen estos escritos y su valor será tema 
del capítulo siguiente, rescato esta afirmación de Lacoue-Labarthe y Nancy sobre la relación entre crítica y crítico:

no hay verdadera crítica si no es a través de la captación del Todo de la obra y por la caracterización simple, directa, esencial y que por esta razón va derecho a los rasgos característicos, que son menos los de la obra que los de eso que, o los de quien, opera en la obra. (484)

Connolly, durante este año crítico, escribe y llena tres cuadernos, y en su escritura (y reescritura) se entrevé una intención artística que en cierta manera los diferencia de otros fragmentos de sus diarios que se publicaron póstumamente. Pero es recién al releerlos que el crítico-escritor percibe una forma artística dominante: "una iniciación, un descenso a los infiernos, y una purificación y una cura" (Connolly 2005: 392); pero esto, evidentemente, no es algo que supiera mientras los escribía, dado que no los escribe como una retrospectiva del proceso, una mirada atrás, sino que deja constancia del proceso mismo, "la escritura había hecho al escritor" (2005: 393). Las preocupaciones de ese año giran, sin embargo, alrededor de ciertos temas recurrentes (el arte, el amor, la naturaleza, la religión), que adquieren así una estructura sinfónica, dado que cada cierto tiempo el tema vuelve a ser escrito, pero no de la misma manera ni como continuación del tratamiento anterior. Cada uno tiene su lugar en el periplo, y es una totalidad en sí mismo, aunque una totalidad fragmentaria, inacabada, que se resignifica como parte de un conjunto, aunque no exista progresión. El libro trata sobre las búsquedas de salvación de un sujeto en crisis, pero la salvación, que en principio está fuera de las indagaciones de la escritura del libro mismo (librarse del Angst, recuperar al ser amado, escribir por fin la obra), termina siendo la escritura misma del libro, de este libro: "como demostración del poder de las palabras, del ímpetu obsesivo de una forma estética por cumplir su destino, la obra fue una lección” (2005: 397). Es decir, la obra tiende hacia un objetivo, externo, se proyecta hacia su búsqueda, pero el proceso en tanto escritura acaba siendo el objetivo mismo, mutado en obra, que, sin embargo, preserva su apertura. La obra que buscando la obra es la obra misma; el escritor que buscando las posibilidades y potencialidades de sí en tanto artista, se hace artista en el proceso, y Sujeto-Obra, sujeto del arte.

La Obra es lo que el autor no sabe, ni podrá saber, pero Connolly escribe como si algo de ella le pudiera ser revelado en el proceso. $\mathrm{Y}$ hace lo contrario de lo que recomienda: pone lo mejor de sí en formas de expresión que ni siquiera aspiran a ese absoluto; trabajos efímeros, y que por tanto no deberían ser emprendidos. Mediante este 
subterfugio Connolly evade el silencio, que sería el fin inevitable, extático, ante la imposibilidad la Obra. Sin embargo, ya desde el comienzo del libro, se pregunta: “¿Qué es una obra maestra?" (2005: 404); lo que es en sí no puede decirlo, pero puede dar ejemplos ${ }^{79}$. Tampoco puede decir qué rasgos del ideal absoluto poseen, pero reconoce cómo interviene en ello su gusto -por más que, como veremos en el capítulo siguiente, sea un gusto compartido-, y se pone como sujeto de dicho saber: "Semejante lista revela mucho de su autor" (2005: 404). Lo que sí puede decir es lo que estas obras tienen en común para satisfacer su gusto; no sabe cómo escribirlas, pero las busca en sí mismo, en tanto posibles, porque "estas obras maestras (en su mayoría cumbres de una cordillera secundaria) reflejan bien lo que le gustaría ser o un yo que teme confesar" (2005: 405). Aquí se ve cómo el fragmento se proyecta, es proyecto de la Obra, pero también del escritor; habla de otros para hablar mejor de sí, se busca en esas obras, porque es lo que le gustaría ser, lo reflejan, pero sólo en tanto proyecto, y su escritura es el deseo de esas obras, un en-torno a ellas para intentar saber por qué se le niegan (y por qué se le niegan otras cosas). Y se le niegan a él en tanto cuerpo de la escritura: es por eso que se pone en el centro de la indagación. Si para escribir bien hay que sentir bien, pensar bien y bien decir, según él mismo cita a Buffon, debe buscar cuál es la falla en sí mismo: "No podemos pensar si no tenemos tiempo para leer, ni sentir si estamos agotados emocionalmente, ni construir con materiales de mala calidad algo que perdure. No podemos coordinar algo que no existe" (2005: 404). En tanto ensayista se reconoce cuerpo de la escritura, él es el material de la obra; lo que se proyecta de la obra debe estar antes en él, debe existir previamente. El saber que Connolly presenta aquí no se da en la forma de la crítica literaria tradicional, no quiere escribir una obra sobre las obras (“¿Cuántos libros escribió Renoir sobre cómo pintar?”, 2005: 404); se escribe como sujeto de ese saber para poder encarnarlo, se escribe para poder proyectar la obra en tanto él no puede dejar de ser su material: quiere saber la literatura en sí mismo, y no como conocimiento abstracto. Ya tiene sus modelos a seguir a la hora de escribir, pero no puede saber cómo lo hicieron, porque ese es un saber de la experiencia del hacer: "Aunque no sé de las condiciones para crear una obra maestra, al menos puede intentar trabajar al mismo nivel de intención que los Sagrados Doce [sus modelos]" (2005: 405). Es un saber de la práctica, y es por eso que el saber del ensayo y el fragmento se da con

\footnotetext{
79 “Las Odas y las Epistolas de Horacio, las Églogas y las Geórgicas de Virgilio, el Testament de Villon, los ensayos de Montaigne, las fábulas de La Fontaine, las máximas de La Rochefoucauld y La Bruyère, Les Fleurs du Mal y el diario íntimo de Baudelaire, los poemas de Pope y de Leopardi, las Illuminations de Rimbaud, y el Don Juan de Byron" (Connolly 2005: 404).
} 
los mismos materiales de la literatura, la interroga según su modo, con su lenguaje, y no desde la posición del observador externo. De manera que el proyecto de esta obra podría resumirse en este fragmento de Connolly: "un experimento en autodescomposición, una búsqueda de lo que obstruye la fuente del manantial, por la que el nombre de Palinuro se está convirtiendo en sinónimo de frustración” (2005: 406).

En los dos libros analizados, paradójicamente las obras principales de Cyril Connolly, puede verse cómo quien querría ser escritor, quien se proyecta escritor, busca en sí las posibilidades de la obra, los modos y hábitos que la posibilitan o, por sobre todo, los que impiden su alumbramiento, dado que, si bien aún parte de la obra tiende hacia el futuro - por eso escribe- el ensayista rastrea y analiza las fallas que hasta ahora le han impedido convertirse en escritor. Pero lo hace en un doble movimiento para que la búsqueda misma pueda ser literatura, en tanto género y en tanto estilo, porque la escritura misma de la búsqueda es la tentativa de la Obra, que al fin se convierte en obra. En ambos libros, el material de la búsqueda, con asedios diferentes, es el escritor mismo y lo que la literatura es en él, no lo que es en tanto objeto, porque lo que se rastrea es su pasado, las fallas en su carácter y formación que le han impedido escribirla, y el germen de la obra en tanto posibilidad futura. Por eso la crítica que efectúa, el saber de la literatura que se pone de manifiesto, no es un saber teórico o sistemático, sino que se da en la experiencia de la lectura y la escritura de una promesa de autor, de una obra en potencia dentro de sí. Es por esto que podemos emparentar la peculiar crítica que estos libros de Connolly ejercen con la "antigua crítica perdida" que define Gotthold Lessing:

una crítica "que no sería tanto el comentario de una literatura ya presente, terminada y marchitada como más bien el órganon de una literatura que aún está por acabar, formar e incluso comenzar. Un órganon de la literatura, y entonces una crítica, que no tendría solamente que conservar y explicar, sino producir ella misma, al menos orientando, ordenando, suscitando." (citado en Lacoue-Labarthe et al 488) 


\section{Fundamentos autobiográficos de la crítica literaria}

\subsection{EI papel del crítico en la formación del valor literario}

Más allá de las funciones antes establecidas, que la crítica cumple, o deja de cumplir, en el más amplio campo de la esfera pública, ésta tiene un lugar muy específico dentro de un campo literario autónomo. Es sabido que el estudio en profundidad de cualquier obra literaria, siempre y cuando no se detenga únicamente en sus particularidades textuales, requiere del establecimiento de un contexto de producción en donde ésta se juega su reconocimiento y legitimidad; pero previo a esto considero esencial establecer las mecánicas generales de los campos literarios, donde se forma verdaderamente el valor de las obras y, en especial, el papel que desempeña la crítica en las luchas por obtenerlo y otorgarlo.

Para Pierre Bourdieu, si queremos darle un carácter científico a estos estudios de literatura, debemos dejar de lado ciertas mistificaciones, o realidades irreductibles, inaprensibles a través de un estudio metodológico riguroso ${ }^{80}$; entre ellas, la originalidad creativa del escritor. El estudio de Bourdieu se centrará entonces en definir las relaciones posicionales de los actores dentro de un campo literario de cierta autonomía, que a su vez está inserto y en relación con otros campos. Concibe a las sociedades modernas como un conjunto de campos que, por un proceso de complejización y diferenciación interna, van adquiriendo una relativa autonomía con respecto a otros campos mayores; así van configurando un sistema de leyes específicas mediante el cual rigen sus relaciones de fuerza, las luchas particulares mediante las cuales se ocupan determinadas posiciones. En el caso que nos interesa, podemos hablar de un "campo literario", de un "campo artístico" y de un "campo de producción cultural" formando "una serie de denominaciones conceptuales de extensión creciente en la que las primeras quedan subsumidas en las últimas" (Pastormerlo 93). Los conceptos de "campo" y "autonomía" son indisociables, dado que un campo no puede constituirse como tal sin un grado de autonomía que le permita diferenciarse; en este sentido, el campo literario no fue tal en tanto no se diferenció de las instituciones externas que legislaban en materia de literatura (Estado, Iglesia, clases dominantes, etc.).

\footnotetext{
${ }^{80}$ Me parece importante aclarar en este momento que, si bien los estudios de Bourdieu tienen gran productividad a la hora de aplicarse en casos literarios particulares, no son estudios literarios propiamente dichos; se trata de sociología de la literatura o de la cultura; y Bourdieu es un sociólogo. De ahí que una metodología empírica rigurosa sea siempre parte de sus preocupaciones; aunque después, en mi análisis, me aparte de ellas.
} 
Es de notar cómo estos conceptos acuñados por Bourdieu permiten una superación tanto del estructuralismo como del marxismo, imperantes en la Francia del momento ("Campo de poder y campo intelectual" se publica en 1966). Si por un lado deja fuera los sistemas inmóviles del estructuralismo, por otro supera ampliamente la teoría del reflejo marxista (base $\rightarrow$ superestructura). La producción de un escritor no está ya determinada por su clase social de origen, sino que estas determinaciones sociales influyen de un modo indirecto: son "refractadas" por la lógica específica del campo, y el "desvío" o "traducción” que sufren será mayor cuanto mayor sea el nivel de autonomía del campo.

En una mirada que intenta ser más abarcadora, geográficamente y en la generalidad de los sucesos, Pascale Casanova configura y analiza, desde una perspectiva de grata deuda para con Bourdieu, lo que ella da en llamar "República Mundial de las Letras”. La República de las Letras, al igual que en Bourdieu, nunca está completamente superpuesta al universo político-económico; su geografía se forma "a partir de la oposición entre una capital literaria (universal, por ende) y regiones que dependen de ella (literariamente) y que se definen por la distancia estética que las separa de la capital" (Casanova 24). Esta República de las Letras se asienta sobre una ficción, según la cual la literatura se rige por parámetros puramente estéticos y desinteresados, autónomos, internacionales, que nada deben a los intereses político-económicos nacionales; esta ficción oculta que la historia literaria es la historia de facciones que rivalizan teniendo a la literatura por objeto, y que en el espacio literario presentan una estructura desigual; la literatura mundial es el resultado del valor creado mediante esas luchas.

La formación de los Estados nacionales está directamente vinculada a las lenguas nacionales que les sirven de vehículo político y social de cohesión; por tanto, en sus inicios las literaturas nacionales -máxima expresión de sus lenguas- son inseparables de la formación del Estado; son, además, una herramienta que éste utiliza y controla a través de sus instituciones (academias, sistema educativo, premios, cátedras, etc.). En un principio, el prestigio de la lengua está asociado a la importancia del Estado. Con el tiempo, mediante un proceso de diferenciación, la literatura va cobrando autonomía, dado que en su desarrollo acumula recursos propiamente literarios; esto genera un movimiento de reflexividad progresiva donde ésta comienza a regirse cada vez más por sus propios criterios y sólo admite su propia autoridad. 
Para Casanova, durante los siglos XIX y XX, la capital literaria ha sido París, al cocentrar en su historia y en su lengua la mayor cantidad de recursos literarios. Connolly también la consideraba tal; es por eso que en La tumba, ante la gran crisis mundial y personal, se vuelve hacia ella, y Francia toda, su literatura y su lengua, como intento de reafirmar la tradición ininterrumpida del humanismo occidental. París, con su temprano desarrollo revolucionario, se convierte en foco irradiador de libertad política y modernidad literaria. Esto tiene un doble efecto: crea su reputación de capital artística (efecto simbólico) y, a su vez, le permite otorgar la consagración literaria (efecto real) (Casanova 48). El mito de la universalidad de París es concomitante con el ahistoricismo de los valores estéticos que propugna; es en estas regiones más autónomas donde se instaura la ficción de la pureza literaria. Así, para obtener su lugar en el canon de la República de las Letras, los escritores de regiones periféricas deben encarnar esta ficción, ocultando la desigualdad de partida (resabios de una dependencia original de la política); la original dependencia nacional hace que este escritor se ubique en el plano internacional de acuerdo con el lugar que ocupa su nación, y de acuerdo con la posición que él ocupa en su literatura.

Dado este escenario de disputas - que Bourdieu, atento a la creación de su teoría, analiza de manera sincrónica y acotada al caso de Francia, mientras Casanova lo mundializa- es innegable que hay algo por lo cual luchar. Al interior del campo literario lo que está en disputa "es un capital simbólico específico (prestigio, reconocimiento o legitimidad literarios), y las luchas que mantienen entre sí los sujetos e instituciones del campo (escritores, revistas, editoriales, etc.) están orientadas a su acumulación" (Pastormerlo 93). Siguiendo la metáfora económica de Bourdieu, Casanova llama al objeto de lucha "valor literario"; es decir, espiritualizado el campo literario por la aparente inutilidad y desinterés del valor por el cual se lucha, no puede encubrir la analogía con los macrosistemas político-económicos donde se disputan valores cambiarios reconocidos por los agentes, sean aquellos el poder o el dinero. Y existiendo el valor, la lucha no cesa, dado que se tiende a la acumulación de un valor siempre amenazado en su posesión.

Se dice que existe un valor literario porque hay apreciaciones y juicios sobre él, y porque hay que pagar algún precio para obtenerlo; en términos de Bourdieu, hablamos de un "capital literario" dentro del campo más amplio del capital cultural. Según Paul Valéry se trataría de un "valor espiritual" dentro de la civilización, que es un capital. Casanova sigue a Valéry para dar la composición del capital cultura o civilización, que 
adapto a la literatura: se compone, por un lado, de objetos materiales, obras literarias y, sobre todo, textos declarados nacionales, que participan de la historia de la nación; mientras más antigua es la literatura, más textos alcanzan la categoría de clásicos, que dan importancia a la nación, su lengua y literatura. El "clásico" se vuelve así la medida del canon, y es el privilegio, la legitimidad, que ostentan las naciones literarias más antiguas, que así definen su capital literario como no-nacional y no-histórico. Por otro lado, el capital literario se compone de hombres que den valor y puedan servirse de esa parte material; que puedan ejercer las costumbres que hacen falta para manipularlo, luchar por él, acumularlo.

Así pues, este capital se encarna también en todos los que lo transmiten, se apoderan de él, lo transforman y lo reactualizan. Existe en forma de instituciones literarias, académicas, jurados, revistas, críticas, escuelas literarias, cuya legitimidad se mide por su número, su antigüedad y la eficacia del reconocimiento que decretan. (Casanova 29)

Tenemos, por tanto, un valor o capital literario al que muchos autores coinciden en aplicar metáforas económicas; tal vez sean las más gráficas para describir la lucha, el intercambio y las desplazamientos que genera. Sin embargo, debemos aclarar que esta “economía de los bienes simbólicos”, según Bourdieu, y, en este caso, literarios, es un espacio de intercambio de bienes o valores que no funcionan según "la lógica brutalmente explícita e inmediata del 'toma y daca"' (Pastormerlo 95); no se benefician de la maximización del beneficio monetario, antes bien, se basan en una denegación de lo económico (un desinterés que es en fin ocultamiento de una doble dimensión: una simbólica y otra económica). Además de la antigüedad de la literatura y el volumen de clásicos nacionales, el valor literario descansa, sobre todo, en juicios y representaciones, que dependen del reconocimiento y la legitimidad que otorgan quienes son considerados idóneos, quienes poseen el 'nombre' necesario. Continuando con la metáfora económica, esta vez tomada de Ezra Pound, los juicios emitidos sobre el saber o la literatura semejan un cheque, su validez depende del firmante. Nadie los acepta firmados por un desconocido sin referencias; se otorga crédito según el nombre del respaldo. Así, “en el universo literario, el valor está asociado directamente con la creencia" (Casanova 30-31). A los juicios de un escritor, un crítico o una institución sobre el valor de determinado objeto literario le otorgamos crédito en virtud de la creencia que en ellos profesamos.

Para que esta lucha facciosa, esta puja simbólica, tenga algún sentido, es necesario pues que exista una creencia axiomática en la importancia de llevarla a cabo. 
El artista o el crítico que decide participar en ella no puede estar más acá de ese axioma; no puede cuestionar su valor fundamental, porque si así fuera no entraría en el campo de juego. La tarea desmitificadora de la literatura y sus normas estéticas, autónomas, está reservada al sociólogo literario, que se permite la disección de la lucha en tanto no participa de ella, no está obnubilado por la Illusio. Se trata éste de uno de los conceptos clave de la sociología de la cultura de Pierre Bourdieu: es la creencia más básica y velada en el juego literario, que comparten -pese a cualquier desacuerdo o disputatodos los que participan en él. La Illusio es la condición necesaria de participación -la lucha vale la pena- y su producto -dado que las inversiones acumuladas producen creencia-.

Este intercambio simbólico, difícilmente mensurable, requiere por tanto de una creencia básica; el valor asociado a la creencia tiene efectos de acumulación simbólica, pero tiene también efectos materiales en la formación del canon, los estudios universitarios, las ventas de mercado, etc. Un escritor, una obra, 'vale' por lo que cree que tiene, lo que se dice que tiene y por quién dice que lo tiene; el capital que acumula depende de la legitimidad y la cantidad de actores que determinen su valor. Así

El capital literario reconocido por todos es a la vez lo que se pretende adquirir y lo que se reconoce como condición necesaria y suficiente para participar en el juego literario mundial; permite medir las prácticas literarias con el rasero de una norma declarada legítima por todos. (Casanova 2001: 31)

Por tanto, desde esta perspectiva se torna, no imposible, pero sí problemático, establecer el valor en sí de un texto en cuanto arte literario; aun cuando la creencia en este valor puramente estético de la obra es fundamental en el quehacer compositivo, en la poética del autor que mediante su trabajo intenta alcanzarlo y del crítico que lo valora, la variedad de cánones, de obras canónicas, y las cualidades por las que se establece su excelencia, hacen que la absoluta norma estética, desligada de cualquier otra circunstancia, sea una aspiración utópica, o por lo menos, un debate sin fin. Hablo de un proceso dinámico de formación del valor literario, dado que no existen cualidades fácilmente determinables que adscriban de inmediato a un texto cualquiera dentro del arte literario. Llevado esto a su extremo, se puede repetir que es literatura lo que se dice que lo es, o se reconoce como tal; debo agregar que, por supuesto, depende de quién lo diga. Es en esta tarea donde el ejercicio crítico cobra capital importancia. 
Para que un texto pueda ser juzgado universalmente, tiene que poder leerse en la o las lenguas 'literariamente' más prestigiosas; no son éstas las que más hablantes tienen, sino aquellas de las que se cree que los textos escritos en esa lengua o traducidos a ella son dignos de atención; las lenguas que más políglotas literarios tienen en su haber. Por esta razón, no se puede dejar de mencionar el importantísimo valor que tienen los traductores literarios dentro de la 'República Mundial de las Letras', dado que son ellos, además de los políglotas, los que hacen posible la circulación de los textos desde las periferias al centro y viceversa.

Pero el que tal vez sea el elemento más importante en la cadena del valor literario es el crítico ${ }^{81}$. El crítico 'respetado' funciona como un intermediario trasnacional que decide y posibilita la circulación de los textos en el espacio mundial; puesto que todos los protagonistas intervinientes en el universo literario reconocen las funciones y competencias de la crítica, sus juicios son seguidos de efectos objetivos, lo que le otorga poder decisivo a la hora de fijar el valor y, en última instancia, decidir lo que es literatura y lo que no lo es. A los críticos se les otorga el derecho de legislar literariamente (Casanova 39); son los jueces competentes del área. Casanova (37-38) cita y parafrasea a Valery Larbaud al hablar de estos críticos cosmopolitas como de una "aristocracia" de las letras, una sociedad de personas cultas provista del poder de veto y consagración; son depositarios de la creencia y pueden otorgarla. Esta sociedad cosmopolita es nacional e internacional a la vez: encarna la cultura acumulada de su nación, y a su vez sólo encuentra sus iguales en las élites cultas de las otras naciones. Es por esto que se presume cierta unidad de juicio, como si todo coincidiera en las cimas. Allí es donde puede observarse la deshistorización que cohesiona a la 'República Mundial de las Letras'. La adhesión a la Illusio necesaria hace que la mayor unanimidad crítica internacional sea competente en establecer 'unidades de medida', válidas como patrones de comparación, dado que, en su función legisladora, la crítica no puede dejar de dar respuesta a lo que Harold Bloom llama "la triple cuestión del agón": más que, menos que, igual a, sin la cual no puede haber valor estético (Bloom 2004: 34). Es por esto que Paul Valéry se refiere a los críticos llamándolos "esos expertos, esos aficionados inapreciables que, aunque no creasen las obras propias, creaban su

\footnotetext{
${ }^{81}$ No pueden desconocerse la labor editorial y mercantil que intervienen en el proceso de circulación de textos, ni negar la vinculación del crítico con estas instancias, siempre y cuando esté condicionado más o menos por ellas. Sin embargo, el valor literario de una obra, la creencia depositada en ella por lo actores con más crédito para hacerlo, no tienen una relación proporcionalmente directa con su valor de mercancía.
} 
verdadero valor"; les asigna un 'saber' desinteresado, incorruptible, que convierte lo que ellos deciden releer, "mediante ese retorno, en valor sólido" (citado en Casanova 38). Estos intermediarios están "ingenuamente investidos" de la representación más pura, despolitizada, de la literatura; “están firmemente convencidos de la universalidad de las categorías estéticas a través de las cuales evalúan las obras" (39). No se trata de un convencimiento propio solamente, sino que los demás actores depositan en algunos de ellos su confianza, creen en su competencia para legislar en materia de gustos: así comprendemos el rol que juega la crítica en la creación del valor literario.

Lo que habilita estas funciones del crítico es su rol social, si bien es de esperarse que llegue a estas instancias por reconocimiento de una competencia individual. Esta competencia no es innata, y es parte de la frecuentación y el esfuerzo, es decir, de la educación. Si bien ninguna persona posee en sí misma el criterio absoluto del gusto, de la crítica correcta, no puede negarse que a algunas personas se les reconoce esta capacidad más que a otras. Según David Hume "la belleza no es una cualidad de las cosas mismas: existe sólo en la mente que las contempla, y cada mente percibe una belleza diferente" (Hume 50). Siendo un escritor empirista, no cae fácilmente en especulaciones abstractas. Sin embargo, a través de la frecuentación de las obras que han sobrevivido al tiempo y al criterio de muchos hombres diestros, a través de la educación de los sentidos específicos para el juicio en cuestión, un individuo determinado logra el reconocimiento de sus facultades. Aunque las bellezas de la literatura no pueden ser sistematizadas ni reducidas a principios generales, y no se reconozca un patrón absoluto, las diferencias de grado en el gusto subsisten, y los juicios de un hombre se estiman preferibles a los de otro. La crítica de Hume es una crítica de la experiencia. La experiencia amplia en un arte determinado, teniendo por medida lo que el consentimiento general ha considerado mejor, brinda términos de comparación; para juzgar es necesario comparar. Descartadas las esencias, se apela a aquellos "modelos y principios que han sido establecidos por el consentimiento y la experiencia uniformes de las naciones y las épocas" (Hume 58). La experiencia reiterada de los objetos de un arte desarrolla hábito, permite adquirir las habilidades y destrezas que estuvieron en el principio de la ejecución, y por los mismos medios se adquiere la facultad para juzgarla; comparación, discernimiento, experiencia, educación, son las posesiones habilitantes del gusto. En un resumen utópico, y no por eso menos deseable -siempre y cuando se lucha por la acumulación de ese capital- esta es la fórmula de David Hume: 
Sólo el sentido fuerte, unido al sentimiento delicado, mejorado por la práctica, perfeccionado por la comparación y purgado de todo prejuicio, puede proporcionar a los críticos este valioso referente. Y el veredicto a él unido, si es que puede ser hallado, es el verdadero criterio del gusto y la belleza. (Hume 63)

Las cualidades derivadas de la experiencia que, mediante el estudio, la comparación y la libertad, dan al crítico las mismas capacidades del creador, confluyen en la conformación de los referentes del gusto, del valor literario: aunque no se den completos en hombre u obra algunos, se deposita en ellos valiosa creencia, a la que podemos estimar como el criterio más firme para cualquier juicio acerca de una obra.

Dentro de un campo autónomo, que se rige por sus mismas autoridades y reglas, el crítico posee un papel fundamental en la formación del valor literario. Dado que la excelencia y la belleza no pueden ser determinadas exactamente como algo perteneciente a la obra en sí, se establecen por la amplia unanimidad de quienes son distinguidos, por su experiencia, facultades y rol social, como los sujetos idóneos para establecer el juicio. Los referentes creados como medida de una excelencia inaprensible, establecen un valor que, dentro de un campo levantado sobre la creencia, configura el capital objeto de las luchas.

Es en el s. XV, en Florencia, donde comienza a darse la constitución de ese campo artístico relativamente autónomo, donde los artistas abogan por el derecho de legislar en su propio orden. Como establecí anteriormente al analizar el papel de la crítica en la cambiante esfera pública, con la revolución industrial se da una ampliación de este campo, consecuencia de la generalización de la enseñanza elemental y de una intensa relación entre la literatura y la prensa cotidiana, con el subsiguiente acceso de nuevas clases al consumo simbólico (Bourdieu 87). Ante esta nueva realidad de "doble faz" de los bienes simbólicos (como mercancía y como significaciones), los productores afianzan un proceso de diferenciación para establecer una jerarquía ante la diversidad de los públicos; dan como resultado lo que Bourdieu llama el campo de producción restringida (de productores para productores) y el campo de la gran producción simbólica (de productores para no-productores) (90). Este ensimismamiento -donde los productores compiten por el reconocimiento propiamente cultural de los pares- hace que el campo se especialice en lo que tiene de más propio: el estilo. El dominio de los principios técnicos y estilísticos se torna habilidad privilegiada en la oposición entre productores; el 'arte puro', 'el arte por el arte', donde prima la forma sobre la función, 
la manera de decir sobre la cosa dicha (69) es parte de un proceso de distinción, en el que quedan relegados todos lo que no alcancen un nivel de recepción acorde con el nivel de emisión cada vez más codificado y hermético (76).

Cyril Connolly, como crítico literario, ocupa una posición ambivalente en el campo literario inglés, haciendo equilibrio entre el campo de la gran producción y el campo restringido; encarnando, como hombre de letras, las tensiones histórico-sociales de la crítica en ese momento dado. Por un lado, se ve en la obligación de escribir en la prensa para un público lego, situación que siempre le merece desprecio:

¿Qué consejo puedo, entonces, dar a alguien que se ve forzado -porque nadie puede hacerlo voluntariamente- a convertirse en crítico? (Connolly 2005: 618)

Escribir crítica es un empleo a tiempo completo con un sueldo de media jornada, un oficio en el cual nuestro mejor trabajo siempre está sometido a la crítica de algún otro, en el que los triunfos son efímeros y sólo la esclavitud de la tarea es permanente, y en el que el futuro no ofrece nada seguro, excepto la certeza de acabar convertido en un gacetillero. (2005: 622)

Podríamos concluir mencionando la bovina indiferencia del público lector, incapaz de desarrollar siquiera la actividad discriminatoria de rumiar. (2005: 622)

El 'reseñismo' no pertenece a los géneros jerarquizados, y no contribuye a ubicar al autor en una posición privilegiada del campo. Por otro lado, consciente de la encrucijada en que se encuentra, Connolly busca en lo posible transformar el valor de su trabajo: "Al hacer la crítica de un libro que te gusta, escribe para el autor; al hacer la crítica de cualquier otro, escribe para el público" (618); y este breve consejo que ya cité: "Nunca escriba una crítica que no pueda ser reimpresa, es decir, que no tenga cierta longitud y trate un tema de valor permanente" (160). Escribir, en fin, para el reconocimiento de los productores, dentro del campo literario.

La creciente autonomía del campo restringido, nos dice Bourdieu, se pone de manifiesto en una tendencia de la crítica no ya a ocuparse de producir instrumentos de apropiación de las obras - cada vez más alejadas del público- sino a "aportar una interpretación 'creadora' para el uso de los 'creadores"” (91). Dada esta solidaridad entre críticos y artistas, los únicos críticos reconocidos son los que han sido iniciados en los misterios del arte y, por tanto, pasan a formar parte del campo restringido.

Cyril Connolly, como nativo de la cultura erudita, se encuentra 'familiarizado' con el arte: no sólo por la adquisición de los saberes que acompañan la frecuentación prolongada de las obras, que permiten la interiorización inconsciente de las reglas de producción, sino por un sentimiento de familiaridad que nace del olvido mismo de ese 
proceso, considerando así natural una manera de percibir que no es sino una entre otras. La experiencia de la obra de arte y el juicio espontáneo sustituyen así "la conciencia teórica de la verdad objetiva de la competencia" (80-81); es por esto que los criterios utilizados para dirimir en cuestiones estilísticas y de gusto permanecen la mayoría de las veces en estado implícito. Lejos de cualquier objetividad, el gusto esgrimido en materia de arte tiene un sentido histórico y social:

Contra la ideología carismática que considera los gustos en materia de cultura legítima como un don de la naturaleza, la observación científica muestra que las necesidades culturales son producto de la educación: la investigación establece que todas las prácticas culturales [...] y las preferencias correspondientes [...] están estrechamente ligadas al nivel de instrucción [...] y, en segundo lugar, al origen social. (231)

En este sentido, y desde otra perspectiva, las nociones de Bourdieu sobre la formación del gusto y sus juicios, no están tan alejadas de las de Hume: experiencia, educación y clase social. Tan bien pareció intuirlo Connolly que, fracasada su tentativa de posicionarse en el campo a través de la novela, escribió Enemigos de la promesa, donde demostraba poseer la capacidad del discernimiento en materia de estilo (lo que el arte de la literatura tiene de más propio) y además nos cuenta cómo la adquirió: a través de un origen familiar cultivado y de la mejor educación de Inglaterra (o la de más peso simbólico), en Eton y Oxford. Esas son sus credenciales, esa su legitimidad.

\subsection{Cyril Connolly, lecturas de un hombre cultivado}

La obra de Cyril Connolly, en tanto hombre de letras, ensayista y crítico literario, se encuentra en una encrucijada, que es la de la crítica misma: o se dirige al público cada vez más amplio y ávido del consumo de bienes culturales, y su crítica se vuelve hacia los valores mercantiles -ya no hablamos aquí de una esfera pública homogénea donde se escribe para iguales y por tanto la crítica tiene relevancia social-; o se refugia en las universidades, donde la crítica, vuelta hacia sí misma, intenta objetivizar sus instrumentos, y volverse una ciencia, un campo de estudio, con sus teorías y métodos propios. Ante este dilema, en ese momento histórico, ejercita una crítica en vías de desaparecer: la crítica de un hombre de letras, ensayística, una crítica del gusto; como afirma Nora Catelli al hablar de la crítica de Connolly: "Tal vez incluso la ligereza y la agilidad del reseñismo periodístico sea el único medio idóneo para imaginar un espacio de discusión del gusto, más allá de la publicidad o la academia" (Catelli 2005). Es decir, la posibilidad de volver a un saber sobre la literatura que no se apoya sobre teoría 
alguna, que carece de metalenguaje, y trata a la literatura según su modo, un saber literario sobre la literatura, el saber de un Yo que existe porque ha leído, que subjetiviza su crítica en la creencia de que, en el fondo, es partícipe de una tradición, y por tanto se trata de un conocimiento intersubjetivo, como Montaigne al hablar de sí, con mucha lógica, creía hablar del hombre.

Si bien este tipo de crítica quedó relegada de los estudios universitarios porque no se basa en presupuesto teórico alguno, y también, en general, de la circulación periodística, dada su extensión, el lenguaje y los conocimientos implícitos que el ensayo conlleva, y ya he analizado, no por eso puede dejar de interrogar en tanto saber existente, cuya legitimidad, aunque problemática, es manifiesta.

Analizaré ahora ciertos aspectos a destacar de la última etapa intelectual de Roland Barthes; los que destaco atañen exclusivamente a su relación con lo que vengo diciendo y diré sobre Connolly. No tomo a Barthes sólo por ser una autoridad reconocida literaria y académicamente, sino también porque, dada su peculiar trayectoria intelectual, dedicó más páginas reflexivas a interrogarse sobre las formas y funciones de un saber ensayístico y subjetivo, y a impugnar o cuestionar otras formas de saber; algo que Connolly, dada la época y la particularidad de su campo, ejerció sin cuestionárselo demasiado, y sin recurrir al metalenguaje. En su carrera (¿cómo ensayista, crítico, científico, semiólogo?) Roland Barthes interrogó al mundo y a la literatura desde las distintas teorías que su época le ofrecía: una primera instancia política, sociológica y conscientemente ideológica, signada por la Historia; otra, marcada por la pretensión científica, donde la lingüística y la semiología prestan sus formas a un análisis estructuralista de la literatura; ya en la teoría del texto, más interesado en las singularidades y diferencias presentes que en abolirlas en favor de un discurso explicativo general, recurrirá al psicoanálisis lacaniano y los textos posestructurales (Derrida, Deleuze); aquí Barthes se encuentra inmerso ya en su último movimiento, el del "giro autobiográfico en clave nietzscheana" (Giordano 2011: 91).

Toda su última etapa, hasta el momento de su muerte, está signada por la búsqueda de un saber autobiográfico, trazado en el cuerpo; en este sentido, $L a$ preparación de la novela, de Barthes, puede compararse a Enemigos de la promesa, en tanto el crítico, pensándose artista, especula sobre las posibilidades de la obra material, que es su verdadero deseo. Todos los libros posteriores a El placer del texto (1973) Connolly muere apenas un año después, y sus libros más relevantes datan de treinta 
años antes- dan cuenta del cambio hacia una subjetivización, que este texto refrendaba; esta fase, donde se siente el eco del pensamiento nietzscheano, se desenvuelve como un proceso, cada vez más autoconsciente de que toda filosofía no es más que la autoconfesión de su autor, una especie de disimulada memoria íntima (Sala-Sanahuja 14); Barthes asumirá el desvelamiento en todos sus pormenores, y aunque no llegará a la autobiografía, sí usará distintos procesos de autofiguración, aun cuando deba prestar alerta a este nuevo 'yo', que se configura con el subterfugio de lo fictivo. En Barthes las palabras-conceptos conllevan una torsión que las aleja del reduccionismo, trascendiendo lo obvio; en el retorno del individuo, del gusto y la sensualidad, de lo amortiguado y 'legible', se ve no una simplificación sino una postura que objeta "la abstracción y la cerebralidad dominantes" (Marty 138). Barthes, como Connolly, sabe que no se piensa sino con la experiencia, de los textos y de las cosas, y por tanto ofrece al sujeto como base de experimento. La 'moralidad' que se presenta como género de esta última fase, nos advierte el autor, "ha de entenderse como el contrario preciso de la moral (es el pensamiento del cuerpo en estado de lenguaje)" (Barthes 1978: 160); ya nada queda fuera de este cuerpo que piensa, y se escribe en el momento de pensar. Al narrar la familiaridad de este cuerpo, toma distancia de su pasado 'científico', dando lugar a una nueva ciencia (fantasmática), la “ciencia del sujeto”. Este nuevo 'yo' de sus textos interroga el quehacer cotidiano, sus gestos, objetos y escrituras "con la intención plenamente intelectual de interpretar la realidad, sin ocultar por ello lo que de pasional, de deseo, posee tal ejercicio" (Sala-Sanahuja 13-14).

Ya en un texto de 1967, "De la ciencia a la literatura", Barthes cuestiona la relación de la ciencia con el lenguaje. Ciencia y literatura no pueden diferenciarse en sus características básicas, dado que ambas poseen sus contenidos, su método y su moral; es más, ambas son, en manera sobresaliente, discursos. En la asunción de este rasgo común se encuentra su principal diferencia: para la ciencia el lenguaje es un instrumento para la comunicación de resultados científicos, que existen fuera de él y lo preceden (la postulación de un imposible: lenguaje científico neutro y primordial, del que todos los demás serían subcódigos excéntricos); en cambio, a través de la escritura, "el lenguaje es el ser de la literatura, su propio mundo" (Barthes 1987: 14-15). Si la ciencia es una materia que, aprendida, puede luego transmitirse, la literatura es una práctica contenida en el acto de su realización.

Cuando Barthes se plantea, en este texto, la supervivencia del 'estructuralismo' (que ya podemos llamar post) en su capacidad de decir algo de la literatura, lo entrevé 
yendo hacia ella, no ya como objeto sino como "actividad de escritura"; sólo si consigue centrar su empresa en "escribirse a sí mismo" (1987: 17), dentro del lenguaje, aboliendo la distinción entre la obra como objeto y la ciencia como metalenguaje, este nuevo estructuralismo podrá decirnos algo sobre lo irreductible del hecho literario. Esta nueva lengua no analiza ni deconstruye los textos; "al contrario, la cosa pasa por adherir lo más completamente posible al objeto, sin la ambición de situarse a distancia de éste" (Marty 133); se comportaría como empática en el deseo.

Lo que Barthes impugna en la pretensión de los metalenguajes es la falacia de la objetividad; "la objetividad, al nivel del discurso [...], es un imaginario como otro cualquiera" (Barthes 1987: 18). Lo que puede intentar excluirse de la escritura es la 'persona'; el sujeto, excluido, se significa en esa misma exclusión: "Todo enunciado supone su propio sujeto”, designado como 'yo', 'él', o recurriendo a giros impersonales; todas estas formas son "trucos puramente gramaticales" (1987: 18). Según Barthes, siendo el imaginario imposible de erradicar, es mejor aceptarlo con total conocimiento de causa, y esto sólo se logra en la asunción plena de la escritura: "tan sólo la escritura tiene la posibilidad de eliminar la mala fe que conlleva todo lenguaje que se ignora a sí mismo" (1987: 18). Es lo que Connolly vislumbra; y por tanto, en su tratado sobre el estilo, la escritura y la vida del artista que es Enemigos, termina remitiendo esos saberes a su propia formación, clase social y educación.

La asunción del cuerpo en el cual el saber de esta crítica se encarna es tan fundamental para Connolly como para Barthes, que cree que los investigadores deben, sin abandonar en los momentos previos los protocolos del 'sabio', “escribir", sacar el ‘уo' de su código científico para entrar en "la infinitud de la enunciación" (1987: 105). El yo, proscripto, puede volver -ya siempre en otro lugar- para atender una exigencia de escritura (discurso del deseo) superadora del discurso científico (Ley).

Otra frontera entre la ciencia y la escritura: el placer. Toda vez que el placer se presenta del lado de la estética, de una apreciación de formas culturales, entra en lucha con los principios políticos y/o científicos, que juzgan el valor según el contenido, "la (buena) Causa"; el placer, como fuerza de neutralización, suspende el valor metafísico de la Causa, y el cuerpo-en-el-placer se detiene más allá, o más acá de la dialéctica, de la Verdad, liberado de la contradicción lógica, "el sujeto del placer es el contrahéroe de 
un heroísmo que no puede ser sino el del sujeto político" (Marty 139) o científicopositivista, agregamos ${ }^{82}$.

Barthes entiende la crítica como irreductible ante el discurso 'cientificista', dada la imposibilidad de poder decir algo del "texto desde el punto de vista de la ciencia positiva (su jurisdicción es la de la ciencia crítica: el placer como principio crítico)” (Barthes 2004: 84). El placer, como el gusto, tiene el peligro de conseguirse con una lógica-otra imposible de rastrear mediante el saber positivo, porque aparece en el momento en que se permite al cuerpo seguir sus propias ideas (2004: 92). Entonces, si para Barthes la crítica es escribir-la-lectura, siguiendo el propio cuerpo, la única manera de poder decir algo sobre lo irreductible literario, es trazar el cuerpo en la escritura.

El texto debe exigirme, demostrar su deseo de mí a través de su escritura, y donde el cuerpo no deja su marca en ella, hace lugar al estereotipo (Barthes 1978: 98); me enfrenta. La escritura libre, que permita seguir al cuerpo y al lenguaje (en tanto significante: reflexividades, juegos de palabras, nombres, citas, blancos, saltos, combinaciones, etimologías, etc.) se postula así como norma de los 'estudios literarios', siempre que éstos, superando la distancia del metalenguaje, quieran interpelar realmente a la literatura.

Como establecí en el capítulo anterior para Connolly, la escritura libre, sustraída en favor del placer y el cuerpo de toda sistematicidad, adviene en este último Barthes como afirmación ante la 'estructura'; concepto abierto, inasible, en movimiento, busca el detalle, el desborde, lo singular, aquello que se sustrae de la estructura. "El que se mete a practicar la escritura acepta bastante alegremente disminuir o desviar la agudeza, la responsabilidad, de sus ideas" (Barthes 1978: 111); la escritura formaría parte de una inercia voluptuosa, una facilidad mental en busca de un saber otro. Esta escritura del placer que, desdeñando la sólida estructura argumental y los rigores del tratado, reclama la nota, la notación, el fragmento, "la significación de la insignificancia" (Marty 126), podemos afirmar que reivindica la escritura ensayística como la práctica de un sujeto en trance de saber.

Como Connolly en La tumba, Barthes escribe por fragmentos, procede por detalles, adicionando; goza, no profundiza. En paralelo: inhabilidad para la composición, para representar "las masas" (Barthes 1978: 101). Si la estructuración

\footnotetext{
${ }^{82}$ Sociedad de Amigos del Texto: "[...] falansterio, pues en él serían reconocidas las contradicciones (y por lo tanto se restringirían los riesgos de impostura ideológica)" (Barthes 2004: 26 ).
} 
marca la racionalidad, la dialéctica, la lógica de un texto, al leer su globalidad; el detalle exporta, como el punctum, a través de un plus de sentido, un trazo por donde la literatura pasa. Porque el ensayista responde con su escritura a la propia convicción y emoción, "únicamente escribe sobre lo que lo conmovió para intentar recuperar la fuerza de esa conmoción, para que eso lo siga conmoviendo" (Giordano 2005: 86 y 125). Esa es su práctica, que es a la vez toda su teoría ${ }^{83}$. Los ensayos son así teorías en acto que intentan responder, mediante un estilo que no está fuera de lo literario, al poder intransferible de los afectos (2005: 121). Al poner del propio lado el azar de la escritura (anteponiendo a la seguridad del sabio, la modestia del escritor) el ensayo opera un "deslizamiento amoroso" que trata de conversar con la literatura en sus propios términos; así, devolviendo la obra al deseo de escritura que estuvo en su origen, dice cierta verdad de la literatura, no mediante un meta-lenguaje, sino afirmando un estilo venido de la pasión (2005: 225); más cuando el crítico se piensa escritor.

Alberto Giordano, como antes mencioné, se aproxima a las prácticas esenciales del ensayo literario como "el género de las reflexiones ocasionales y fragmentarias en las que una subjetividad individualizada por sus gustos y sus talentos conjetura, en primera persona, las razones de lo inquietante de un texto" (2005: 262). Nos advierte, sin embargo, que llama a estos ensayos de nuestro interés 'literarios' no por la temática que los ocupa sino porque, al operar en conciencia mediante la escritura, se sustentan en una legalidad propia de la literatura, en un saber que le pertenece.

Podemos decir que Barthes confía a la escritura -al estilo que deviene escritura-, en tanto determinante de lo literario, todo poder-decir-algo sobre la literatura; este poder no es ya de la teoría, distanciada en tanto no reconoce su entidad escrituraria (no sólo no la reconoce, sino que reprime cualquiera de sus emergencias). El ensayo, en lugar de enmascarar, se reconoce como dramatización del saber, como una "ficción interpretativa" en cuanto conformada por la escritura, y por valores operantes (2005: 237).

Este saber literaturizado no se propone en tanto discurso de la verdad, enunciado verdadero; "sustituye la verdad de una forma por su validez", en tanto se entrega como aceptable (Barthes 1978: 129). (Barthes confiesa un malestar por esta tensión en el ser de la lengua, a veces le parece estar produciendo un discurso doble: el propósito de su discurso no es la verdad, pero sin embargo es asertivo. Trata de consolarse pensando

83 "Repito la fórmula: no hay meta-ensayo del ensayo" (Giordano 2005: 225). 
que el lenguaje es asertivo, no él, 1978: 53). Ante las pretensiones de la objetividad, el ensayista afirma una perspectiva, una "visión de los objetos intelectuales" (1978: 99).

Para decir esa verdad de la literatura que pasa por el cuerpo, nos dice Barthes, tengo que hablar de "mí"; no como una instancia de lector general, sino de aquel que no puede, "ni para bien ni para mal, ser sustituido. Es el íntimo que quiere hablar en mí, hacer oír su grito, frente a la generalidad, a la ciencia" (Barthes 1987: 334).

$\mathrm{Al}$ romper con la naturaleza uniformemente intelectual de sus anteriores escritos Barthes busca la emergencia de cierta subjetividad; estas nuevas formas de practicar la escritura, en vez de ocultar la propia vida, ofrecen al discurso, "como espectáculo y también como objeto de conocimiento, la subjetividad que lo enuncia" (Giordano 2005: 243).

En esta última etapa, Barthes, al igual que Connolly lo hizo durante toda su práctica, se ofrece a experimentar la literatura; para estar lo más cerca posible de su irreductibilidad, realiza un pasaje amoroso del lector que se identifica de algún modo con los personajes, al sujeto en disposición de escribir, que se identifica con el autor de su fantasma. Interroga su cuerpo en ese trance, el de quien no va ya a escribir "sobre" literatura, sino que va a escribir literatura, el crítico como proyecto de escritor. La forma fantaseada, la tercera forma, no es novela ni tratado, una "secuencia que se sustrae a la Ley ancestral del Relato o del Razonamiento"; una forma que, asumiendo el pathos, ya no ejerza ningún poder o presión sobre el otro, porque su verdad es la de los afectos, no la de las ideas; una práctica de Arte y no de Sacerdocio (Barthes 1987: 339), mientras el propio ensayista se vuelve sujeto-de-arte.

Se puede observar en este Barthes una rehabilitación de la doxa a través del lenguaje; inviste la lengua materna, ingenua, como parte de su propósito, buscando en lo trivial la propia singularidad (Marty 155). Así, la doctrina abandona el espacio teórico "para transferirse y desplegarse en la persona de Barthes, convertido en autor de sí mismo" (148). En La cámara lúcida nos dice habérselo fijado como principio: "No reducir jamás al sujeto que yo era, frente a ciertas fotos, al socius desencarnado, desafectado, de que se ocupa la ciencia" (2012: 117). Barthes sabe que toda ley que oprime a un discurso está insuficientemente fundada; liberado a sí mismo, busca un discurso que no sea reductor. Si todo comenzó como enamoramiento de la literatura, hay que evitar reducirla a otro discurso, como si lo dado necesitara de una justificación; la búsqueda es la afirmación de lo irreductible de ese acontecimiento. 
Para Connolly, al igual que para Barthes, la crítica es una experiencia de búsqueda; esa búsqueda no puede sino ser la de la literatura cuando afecta su cuerpo. Así, el crítico acepta erigirse en mediador de la literatura, formulando, a partir de movimientos personales, algún rasgo fundamental. Es la búsqueda de lo que Barthes llamó una Scienza Nuova, que se hallaría en la "cima de la particularidad" (Barthes 1987: 339). Barthes se siente atraído a argumentar sus humores (me gusta/no me gusta), no para justificarlos, ni para llenar el texto con su individualidad, sino para ofrecer esta individualidad a una ciencia del sujeto, cuya mathesis pudiera ser singularis (2012: 46 y 35). Al introducir la levedad del sujeto, soportando con liberalidad la diferencia irreductible de los cuerpos (mi cuerpo no es igual al suyo), Barthes realiza una apuesta ontológica donde la experiencia, la subjetividad, llevada a su absoluto, accedería a una originalidad que trasciende hacia lo universal (Marty 155).

\subsection{Ensayo: una crítica del gusto}

Este excurso tuvo por objeto establecer dos cosas: por un lado, el papel central del crítico en la formación del valor literario, dentro de su campo específico; por otro, la necesidad de rehabilitar el cuerpo del crítico en su escribir la lectura, dado que no puede ser otra la materia que se ve afectada por ella. El valor que el crítico da a una obra, su valoración, se torna efectiva por el crédito dado a un nombre, y ese nombre es el de un sujeto, y el de las experiencias que lo forman. La crítica, habiendo perdido su relevancia en la esfera pública, se vuelve al interior de las universidades, y trata de adoptar métodos científicos que, como sabemos, intentan objetivar el conocimiento limitando la intrusión de lo subjetivo, o, en el otro extremo, se abre a un público heterogéneo, y adopta la lógica mercantil de los bienes de consumo. En ambos casos, por su lenguaje y objetivos, queda fuera del mundo específicamente artístico. Es el ensayo, aún reconocido como uno de los géneros del arte de escribir, quien puede interrogar a la literatura según su modo, y ejercer un saber literario, sin abandonar el ámbito de la crítica, ni más, ni menos, ya que "crítica es cualquier disertación sobre literatura" (Wellek 18). El ensayo se afirma así como un tipo de saber no científico, dado que no se basa en teoría alguna; un saber sin argumentación, que no da razones de sí. Pero si no se basa en teoría alguna, sí es un saber empírico, dado que el fundamento último es la experiencia de un hombre; todo remite a un argumentum ad hominem. Este saber, inscripto en el cuerpo, queda individualizado por el gusto. Se impone por tanto 
establecer qué papel tiene el gusto en la crítica literaria, en la valoración, y de qué tipo de saber se trata.

Según Raymond Williams, en sus Palabras clave, "Crítica se ha convertido en una palabra muy difícil, porque si bien su sentido general predominante es el de descubrir errores, tiene un sentido subyacente de juicio y uno especializado muy confuso, en relación con el arte y la literatura, que dependen de supuestos que tal vez sufran hoy un proceso de fractura" (85). La palabra se generalizó dentro de una clase y luego dentro de una profesión, dependiendo de representaciones de palabras como gusto y cultivo: alcanzar un desarrollo social de las impresiones, cuyas respuestas personales puedan presentarse como estándares del juicio. La confianza en ese juicio se apoyaba en ciertas cualidades del crítico: aprendizaje, cultivo, gusto, sensibilidad. Las formas de esa confianza, y sus depósitos, fueron cuestionadas en distintas etapas, y en el s. XX, en especial, "se hicieron intentos de reemplazarla por metodologías objetivas que proporcionaran otro fundamento para el juicio" (86). La solución no sería reemplazar una palabra tan problemática, cuando la actividad seguirá practicándose, sino liberar ambas de la abstracción de sus circunstancias: lo elevado a juicio como idea y generalidad, es en realidad una respuesta específica, “que no es un ‘juicio' abstracto sino una práctica definida, en relaciones activas y complejas con su situación y su contexto totales" (87).

Con sus problemáticas y cuestionamientos, puede constatarse sin embargo que la crítica es una instancia inherente al campo del arte; más allá de quién pueda decirse artista, está la cuestión de quién tiene el derecho a decir quién es artista, y dada la circulación de los productos artísticos, es importante la existencia de intermediarios que actúan como instancias de consagración y legitimación dentro del campo. Y quien puede decidir es aquel que ha acumulado a través de su educación el capital necesario, y por tanto tiene derecho a hacer una manipulación legítima de esos bienes. En todos sus libros dedicados al tema Bourdieu constata el hecho indiscutible de la desigual distribución del capital cultural, lo que hace que no todos los agentes sociales estén igualmente aptos a la hora de producir y consumir obras de arte. Es más, para ejercer un gusto, se debe poder comparar, dado que lo "que se llama gusto es precisamente la capacidad de hacer diferencias [...], y, en segunda instancia, de probar y enunciar preferencias" (Bourdieu 32). La constitución progresiva de un campo artístico relativamente autónomo lleva consiga la explicitación de principios de legitimidad 
puramente estéticos: afirma "la primacía de la manera de decir sobre la cosa dicha y, por ello, de la forma sobre la función" (69). Vuelto sobre sí mismo en un movimiento reflexivo que constituye su autonomía, el arte sacrifica la demanda del tema por el juego puro de las formas, poniendo el acento, como ya dije, sobre lo más específico de la producción artística: el estilo. Y el estilo en tanto lo particular e irremplazable de cada artista hace que éste se vuelva el tema mismo de la obra de arte, en tanto marca en su producción su dominio del oficio, para reconocimiento de los iniciados. Este tipo de estética por tanto depende, para su valoración, de una manera de percibir que prima sobre la cosa percibida, y opera una distinción: la diferencia tajante, a todo o nada, entre quienes disponen de los modos legítimos de apropiación y quienes no disponen de tiempo libre o medios para hacerse con los recursos que la obra exige ${ }^{84}$ : "La observación determina, en efecto, que la capacidad para descifrar las características propiamente estilísticas es función de la competencia propiamente artística, dominio práctico, adquirida por la frecuentación de las obras o por un aprendizaje explícito de un código propiamente artístico" (73). Porque para ejercer un gusto, emitir una valoración, el crítico debe estar en posesión de una tradición: para reconocer los rasgos estilísticos que definen la originalidad de una obra, debe percibir también las redundancias; las semejanzas permiten apreciar las diferencias. En consecuencia, las personas no cultivadas en estos rasgos específicos, al no tener términos de comparación, ven en la obra su carácter denotativo: su descripción es emocional o sensitiva, dado que carecen de las palabras que nombran las diferencias y las constituyen; es por eso que también perciben de forma indistinta, mientras que el crítico o el artista ven lo específicamente estilístico. Este tipo de distinción se adquiere mediante la familiarización con las obras de arte o el estudio de las mismas, pero es una manera de juzgar entre otras, adquirida; pero los nativos de la cultura erudita tienden a considerarla natural, evidente y fundada en la naturaleza; esto se debe

a que el trabajo de familiarización, es decir, el conjunto de aprendizajes insensibles que acompañan a la frecuentación prolongada de las obras de arte, produce no solamente la interiorización inconsciente de las reglas de producción de las obras

\footnotetext{
${ }^{84}$ La crítica, como capacidad de percibir y juzgar el valor estético es, para Harold Bloom, un saber elitista: requiere tiempo y conocimiento de la tradición. “A mí, el hijo de un sastre, se me ha concedido un tiempo ilimitado para leer y meditar sobre mis lecturas. La institución que me ha sustentado, la Universidad de Yale, es inevitablemente parte del establishment norteamericano [...]. Todas mis apasionadas soflamas sobre el valor estético del yo aislado se ven inevitablemente debilitadas cuando se me recuerda que el ocio necesario para la meditación es algo que debe comprarse a la comunidad. [...]La libertad para comprender el valor estético puede surgir del conflicto de clase, pero el valor no es idéntico a la libertad, aun cuando ésta no pueda ser alcanzada sin comprender tal cosa" (Bloom 2004: 33-34).
} 
sino también el sentimiento de familiaridad que nace del olvido del trabajo de familiarización. (80)

Esto significa que puede alcanzarse el más alto grado de competencia como "dominio práctico de los códigos o del código de los códigos" sin por eso tener el más alto grado de "conciencia teórica de la verdad objetiva de la competencia"; la teoría científica supone una ruptura con la experiencia primera de la obra de arte y con la "teoría espontánea, cara a los virtuosos del juicio del gusto" (81), dado que ésta se funda sobre la experiencia e ignora su particularidad, no puede dar razones de sí.

Por tanto, el gusto esgrimido con respecto a estos bienes culturales es algo adquirido, y su valor depende directamente del nivel de instrucción y del origen social $^{85}$. Porque el gusto aplicado a la apreciación estética, en tanto es diferencial y relacional -quien no posee conocimiento no puede juzgar al no poder comparar-, es fundamentalmente histórico: las obras adquieren valor en referencia a la historia específica de una tradición artística. Las obras, dentro de un campo de producción autónomo, reclaman una disposición que es parte de una competencia cultural específica, que permite identificar los rasgos distintivos que éstas proponen. Pero este conocimiento, dominio o saber, puede negarse su reflexividad, en tanto fundamento teórico, y permanecer sus criterios implícitos en el juicio, en estado práctico, aun en los casos de "los profesionales de la atribución" (236), o críticos.

Es así que el gusto puede ser un saber válido sobre el arte, aunque no sea científico, en tanto que basado en teorías y métodos explícitos y objetivos. Si es un saber adquirido, no natural, que no proviene de una impresión de la esencia de la cosa, no por eso es un saber que pueda dar razones de sí.

Según Hegel, el gusto se opone a los dos sentidos teóricos -la vista y el oído-, ya que no deja al objeto libre para sí, sino que tiene que ver con él de una manera práctica (citado en Agamben 7). En el curso de los siglos XVII y XVIII se comienza a identificar la facultad específica para el juicio y el goce de la belleza con el gusto; se trata de un saber que goza de lo bello y un placer que juzga la belleza. El enigma del gusto, su problemática, se encuentra en esa intersección entre saber y placer; se trata de "otro saber" (dado que no puede dar razones de su conocer, pero goza de él) y de "otro placer" (dado que conoce y juzga); según la expresión de Montesquieu, coincidente con

\footnotetext{
${ }^{85}$ Según Bourdieu se considera más noble y legítima una cultura adquirida por el nacimiento en una familia cultivada, dado que proviene de la experiencia directa y de la delectación, consiguiéndose sin esfuerzo ninguno, contrario al caso del estudio.
} 
la "familiaridad" de Bourdieu, "El gusto natural no es una ciencia teórica; es la aplicación pronta y exquisita de reglas que ni siquiera se conocen" (citado en Agamben 25). La ciencia conoce la verdad, pero no goza de ella, y el gusto goza de la belleza, pero no puede dar razones de ella; la belleza no puede ser conocida y la verdad no puede ser vista, en esta fractura entre verdad y belleza se funda la otredad del gusto (Agamben 19). En tanto juicio de lo bello, el gusto se presenta distinto tanto de la sensación como de la ciencia, una idea de conocimiento distinta entre el placer y el saber. Ya en el s. XVII Leibniz observa que los artistas, aunque juzguen bien las obras de arte, al ser interrogados por las razones de sus juicios, remiten a un no sé qué (24), falta o sobra algo que no se puede decir; se trata por tanto de un juicio que discierne sin discurso. Faltante o sobrante que no se puede explicar, porque lo bello, en tanto objeto del gusto, se presenta como algo puramente relacional, un objeto vacío, un puro "significante, independientemente de cualquier significado concreto" (29-30). El gusto es, en consecuencia, un saber que no puede dar razón de sí, porque se sustenta sobre un puro significante; y un placer que permite juzgar sustentado en algo que en el objeto es pura significación.

Según Georgio Agamben, la concepción de lo bello como significante excedente y el gusto como saber/placer de este significante, encuentran su expresión más rigurosa en la Crítica del Juicio (1790), de Immanuel Kant. El placer estético, en tanto se trata de un exceso de la representación sobre el conocimiento, se halla ligado a la aprehensión de la forma del objeto de la intuición, sin referir a un concepto en vista de un conocimiento determinado; por esto, la representación no refiere al objeto sino únicamente al sujeto. Esa representación es sólo una finalidad subjetiva formal del objeto, que procura placer al expresar la conformidad del objeto con las facultades cognoscitivas que están en juego en el juicio reflexivo (que para Kant tiene carácter universal). Ese placer ligado a la representación funda lo bello, y la facultad de juzgar mediante tal placer se llama gusto (citado en Agamben 34). El juicio del gusto es por lo tanto un excedente, tanto del saber -dado que no conoce pero se presenta como placercomo del placer -en tanto no goza del objeto (de ahí la comunicabilidad universal de ese placer) y se presenta como saber-. Esta condición híbrida del gusto funda una antinomia difícil de precisar mediante la razón: el mismo Kant debe remitir a un fundamento suprasensible para estos juicios y a un desconocimiento de sus fuentes ${ }^{86}$.

\footnotetext{
86 “Sólo se puede mostrar el principio subjetivo, o sea, la idea indeterminada de lo suprasensible en nosotros, como la única clave para explicar esta facultad que poseemos y cuyas fuentes permanecen
} 
Estamos pues ante un saber que se presenta como conocimiento en el momento mismo de subrayar su imposibilidad. Un saber que el sujeto propiamente no sabe, en tanto no puede dar razón de él, algo que falta o es excesivo en la interferencia entre el conocimiento y el placer. (Y ya vimos con Barthes el problema que el placer, y su sujeto, causan a la ciencia). La belleza, como excedente del fenómeno sobre la ciencia, en tanto existente, lleva a otra paradoja: un saber que el sujeto no sabe, pero que le place; pero entonces también hay un sujeto de ese deseo, pero no un sujeto del conocimiento: "La pregunta última a la que lo bello (y el gusto como "saber de lo bello") remite es, entonces, una pregunta sobre el sujeto del saber: ¿quién es el sujeto del saber? ¿Quién sabe?” (Agamben 42).

\subsection{Cyril Connolly, personaje y fundamento}

El ensayo, que al tratar sobre literatura es crítica literaria, está escrito por alguien. Esta obviedad, sin embargo, trata de ser atenuada mediante el recurso a cierta impersonalidad en los predicados o el recurso a la simple aplicación teórica. El crítico se niega a sí mismo en tanto cuerpo de saber y de escritura. Ese cuerpo, con su biografía a cuestas, es el que ha sido tocado, o no, por el texto, y el que responde con su propia escritura. Y ese cuerpo, como afirma Giordano, conjetura en el ensayo a partir de "una subjetividad individualizada por sus gustos" (2005: 262). Como acabo de decir, el gusto, en tanto saber que no se sabe, saber otro, carece de explicación; como significante sin significado, carece también de discurso. El saber científico, en tanto verdad objetiva, aparte de quien la enuncie, se impone en su discurso el ocultamiento del sujeto; pero el discurso del ensayo muestra, "como espectáculo y también como objeto de conocimiento, la subjetividad que lo enuncia" (2005: 243).

Así, la autofiguración en los ensayos de Cyril Connolly se convierte en la dramatización de un saber que no puede explicarse. La apreciación artística, que depende del ejercicio del gusto, es fatalmente personal; por eso, tener representaciones para conocer a quien la realiza, nos permite juzgar sobre la cosa con más elementos. El crítico debe ofrecerse él mismo como objeto de conocimiento porque es el único fundamento de lo que dice. El saber que se presenta a la luz está inscripto en un cuerpo, y por eso en la obra de Cyril Connolly siempre se hace patente que se trata de un saber autobiográfico. 
En el capítulo anterior ya precisé la conciencia que Connolly tenía de este proceso crítico, y por eso se ofrece en la tercera parte de Enemigos de la promesa como fundamento único de sus juicios; termina un libro de crítica literaria con la autobiografía del crítico, donde pone a consideración los episodios de su vida que han tenido "una intervención directa en las especulaciones literarias en las que se basa la primera parte" y demuestra que "las teorías literarias mencionadas en la primera parte reaparecen en la tercera, donde queda patente que tienen su origen en la existencia misma" (Connolly 2005: 32).

Si la objetividad es imposible, si en los fundamentos del juicio estará inexorablemente la subjetividad, es preferible hacerse cargo de ella en el enunciado mismo; sin enmascararla, ofrecerla como objeto de conocimiento. El mismo Connolly lo supo, y en vez de ocultarse, siempre vinculó sus críticas con su autobiografía. En la "Introduction" a Previous Convictions (1963) declara: "And this book is so arranged that it builds up to a picture of the author; an ageing Narcissus complete with pool" (1963: xi). Asimismo, al final del prólogo de su 'lista' canónica Cien libros clave del movimiento moderno (1965), dice: “Aunque intentásemos ser objetivos, una lista semejante (¿una exhibición de pedantería compulsiva o una deuda de gratitud?) es tan personal como un electrocardiograma" (1993: 17). Ya en La tumba inquieta, al dar la lista de obras maestras que comenté en capítulo anterior, confesaba: "Semejante lista revela mucho de su autor. [...] Por tanto estas obras maestras (en su mayoría cumbres de una cordillera secundaria) reflejan bien lo que le gustaría ser o un yo que teme confesar" (2005: 404-405).

Porque la apreciación que el crítico hace del objeto artístico habla más del crítico que de la obra; y, es más, habla más eficientemente de la obra en tanto más conozcamos al crítico. Por ejemplo, cuando leo: "Pedro Páramo es una de las mejores novelas de las literaturas de lengua hispánica, y aun de la literatura", una afirmación que en sí misma no es verdadera ni falsa, es la manifestación de un gusto, me dice más del valor de esa novela saber que la frase es de Borges, que se jactaba de no leer a sus contemporáneos y tampoco novelas, y cuyas preferencias se dirigían a literaturas de otras lenguas y otros temas. O si leo la afirmación: "Si me apuran, digo que Walsh es mejor que Borges", ésta adquiere todo su significado si sé quién es David Viñas.

Dado entonces que el gusto se forma a través de la familia y la educación, parte de una forma experiencial, y que en tanto preferencia es un saber, pero que no puede dar razones de sí, siempre es mejor que el crítico y sus gustos sean patentes, se ofrezcan al 
igual que sus juicios y conclusiones, de lo contrario, mediante el recurso a la elipsis y un hábil manejo del discurso y la teoría, lo que se hace es disimular una preferencia y una opinión personal, y darle la apariencia de un hecho objetivo. Por eso Connolly, además de presentarnos los elementos de autofiguración que vengo detallando, siempre trata de dejar en claro cuál es su gusto, desde qué punto de vista enuncia: como ya comenté, en la introducción a Condemned Playground, dice que disfruta escribir sobre los grandes artistas formales retirados del mundo, sobre los jóvenes feroces y talentosos y sobre los epicúreos que mezclan el gusto con el chismorreo de buen tono (1945: 7); y en su ensayo "Críticos", expresa así sus preferencias y aversiones, que me permito citar porque son fundamentos que de distintas maneras se repiten en toda su obra:

Los críticos pueden dividirse en dos clases. Para unos la literatura no debe ser demasiado esotérica, no debe preocuparse en exceso por el estilo y la imaginación. A mí sólo me gustan dos tipos de novelas: la obra de arte o el libro de escaso grosor, y la novela de entretenimiento. El otro tipo de crítico prefiere la ficción didáctica; para ellos las novelas que yo más admiro simplemente rebosan de escritura bonita, frívola, entretenida o egotística. En su opinión la novela no es un fin en sí misma, sino un instrumento para corregir las injusticias, para transmitir información o exponer teorías. Wuthering Heights puede reivindicar a miles, pero Uncle Tom's Cabin reivindica a cientos de miles. En mi opinión, la novela de propaganda política, más que ninguna otra, es tan indigesta como una bala de cañón en un pudín de ciruelas. (2005: 620)

Connolly, en cuanto crítico que ambiciona el arte, siempre se encuentra preocupado por el estilo y las formas; y su crítica no sólo se ocupa del arte y las formas, sino que ella misma trata de ser arte, de participar de alguna manera de él. Es por eso que, aunque escriba una reseña, su preocupación va más allá de la mera actualidad, y trata de que todo lo que escribe pueda ser reimpreso. Así es también que se aleja de la crítica didáctica o de la propaganda, que responden a una coyuntura, y pueden perder valor una vez que los problemas a los que respondía han pasado. Así defiende la postura al frente de su revista: "Horizon describes itself as a review of literature and art. That is to say we believe in the aesthetic approach; that art and literature exist in their own right -not as symptoms of political attitudes nor ad majorem Dei gloriam” (1953: 196).

Este tipo de crítica, dado que se piensa como una aproximación estética a lo estético, participa del arte, responde o reacciona al arte con sus mismos medios, y por tanto no pretende la objetividad del periodismo o de la ciencia, sino el ejercicio de un gusto, saber de lo bello, placer que juzga lo bello, distante del sentimiento y de la ciencia, en tanto conocimiento entre el saber y el placer. Pero ese gusto es deudor de un cuerpo en el que se ha desarrollado, en contacto con las formas del arte, y así depende 
de un punto de vista. En ciencia, ateniéndose al método que es parte de la teoría, se trata de evitar la intrusión del punto de vista de quien observa, y la persona gramatical del nosotros representa la intersubjetividad que da acuerdo a la teoría. Pero en la aproximación estética esto se vuelve imposible, o por lo menos falaz. El ensayo que, como vengo diciendo, es el medio idóneo para este tipo de crítica, debe evitarlo; como dice Cynthia Ozick: "El ensayo genuino, por el contrario, nunca piensa en nosotros; el ensayo genuino puede ser el escenario más egocéntrico (la palabra más amable sería subjetivo) jamás concebido para el pensamiento humano" (17). Sin embargo, esta falacia gramatical, ha sido una práctica común de la crítica; el mismo Connolly trató de ser sometido a estos dictados: "La primera vez que me dieron novelas para reseñar me confiaron las dos reglas de oro de este género del periodismo. Nunca usar la primera persona del singular y siempre relacionar los libros por algún denominador común"; pero tempranamente se da cuenta del enmascaramiento que hay detrás de la asepsia gramatical, y cree que es hora de romper estas reglas: "Un mero veto a un pronombre personal no impide a un crítico hablar de sí mismo, y ya que la reseña de novelas es a tal punto un asunto de preferencias personales, parece absurdo negar este hecho" (2005: 623-624). (Sobre el hecho de agrupar las novelas por alguna temática común, opina que es culpable de la falta de criterio al evaluar ficción, dado que no se los clasifica por sus méritos). Poco más tarde, durante tantos años al frente de Horizon, dice que: "I found that the word 'we' is always the prelude to a string of clichés" (1945: viii), es decir, repetir palabras de otros, dejar de lado la singularidad de lo personal.

En un ensayo inédito, "El punto de vista en la crítica literaria”, Juan José Saer parte de unas palabras de Butor sobre Barthes para reflexionar sobre la impersonalidad en la crítica literaria: "la formulación impersonal es una manera de ponerse a resguardo. Es confesarse por la boca de todos" (51). El crítico, al no hablar en su nombre, institucionaliza su acto, haciéndolo parte de lo que ya se ha dicho, lo que ya se sabe; encubre una tautología. Al hacerlo, delega su responsabilidad en una abstracción, el "ellos" o el "nosotros", temiendo afirmar su existencia: "Todos los puntos de vista críticos que no sean la primera persona del singular no son más que abstracciones" (52). La literatura, y el arte en general, en tanto selección y orden, son lo contrario de una abstracción; así es que Saer opina que al entrar en literatura uno se encuentra en el reino de lo concreto. Y el deslumbramiento que el arte produce sólo puede ser vivido al participar en una relación concreta, a la que no se accede más que a través del yo. De lo concreto es que se parte luego hacia una abstracción, un saber que no puede separarse 
de la emoción y la sensibilidad del yo que se estremece en la relación; experiencias que sólo el yo puede vivir; "y para hablar de ellas la única humildad y el único rigor posibles consisten en relatarlas desde ese punto de vista" (53). La abstracción del discurso científico simula el conocimiento de todos los datos, un ente donde nada queda librado al olvido o el azar, la totalidad. "Pero para dedicarme a hacer crítica literaria, debo comenzar diciendo: "yo"" (53); porque así se pone en funcionamiento la disponibilidad para la aventura de una relación concreta. Asumiendo su yo el crítico se abandona a sus límites, los de su cuerpo, su experiencia, sus saberes, y se reencuentra con la literatura a través de aquello que la distingue y constituye: un punto de vista. Porque la literatura, entre otras cosas, es el ordenamiento del mundo a partir de una perspectiva humana. Saer es partidario de que ese yo de la crítica se afirme cada vez más, dando a la crítica una evidencia más sólida de verdad, una verdad peculiar de la literatura. Para ello la crítica debe abandonar el abrigo de la impersonalidad y la abstracción: "El punto de vista justo es la única garantía -o por lo menos la condición sine qua non- de la exactitud de mis afirmaciones. Cuando delego el 'yo' en cuidadosos impersonales, 'ellos', 'nosotros', hablo, con el pretexto de la literatura, de otra cosa: sociología, lingüística, psicología" (53). Para que esto no suceda, y para que tampoco sea una tautología, la crítica literaria debe encontrar en el ensayo su forma, una forma que se corresponda con la materia que trata y que provenga y se afirme en el yo. Entonces, a través de este tipo de escritura ensayística, que no sólo asume su yo sino que lo dramatiza, la crítica deja de ser un discurso 'entre' la literatura y el mundo, ajeno, y se vuelve ella misma literatura, creación, poesía.

La crítica se basa en una experiencia de lo concreto de la obra, en algo vivido por el yo; pero no se basa en esta única relación. El juicio depende de las experiencias previas del arte que formaron al sujeto -es evidente que no puedo juzgar una novela si sólo conozco una-. En esta relación con el conocimiento anterior la obra adquiere un valor: valor con respecto a una tradición y un campo específicos, que son de por sí ámbitos relacionales. Pero las reglas que los dominan no pueden legarse ni heredarse de manera infusa, dependen de la actualización de esas experiencias en el sujeto crítico. Tanto Hume, como Bourdieu y Agamben coinciden en que el gusto se forma por la frecuentación, tenga o no luego conciencia teórica de los procesos de su adquisición. Esa familiarización hace que se interioricen inconscientemente los procesos de producción de las obras y, estando en posesión de una tradición, se pueden hacer distinciones; esa 
es la labor crítica. Pero más allá de la posible exteriorización de esas distinciones, lo que se produce cuando esa obra afecta al crítico, es un deslumbramiento estético que queda más allá de sus conocimientos. En tanto excedente del conocimiento, este saber que es placer, este gusto, es un significante sin significado. Su incapacidad de dar cuenta de sí mismo, este encontrarse entre el conocimiento y el placer, no invalida su legitimidad de saber. Así lo entiende también, en la tradición del ensayismo inglés, Oscar Wilde, cuyas especulaciones en todo coinciden con la de los autores citados:

el arte no se dirige en primer término a la inteligencia ni al sentimiento, sino al sentido artístico; en varias ocasiones nos muestra ese sentido artístico, ese gusto, como él lo llama, educado y perfeccionado por el frecuente contacto con las obras maestras y que acaba por convertirse en un juez severísimo. (Wilde 149-150)

El gusto, ese sentido artístico, se convierte en crítica, dado que es el elemento idóneo para juzgar la belleza, aun antes de volverse discurso. A esto mismo se refiere Connolly al decir: "Experience develops in the critic an instinct, which, like a water-diviner's, agitates him when near to treasure. He digs and explains afterwards" (1945: vii). Lo que el ensayo puede hacer por la crítica, haciéndose cargo de ese después, es responder a la obra, en un deslizamiento amoroso, con un lenguaje de arte, prolongando el efecto estético que estuvo en su origen; responder a la literatura según su modo, como dice Giordano. En el ensayo el lenguaje de la crítica se identifica con la materia que trata.

El crítico, reconocido por los creadores y pares, cuyo nombre adquiere crédito, crea mediante su gusto un valor de lo literario. Para que podamos estimar con justeza el rigor de verdad de ese valor, el crítico debe asumir el yo en su discurso, dado que nos habla de un saber que se da en la cima de la particularidad; por tanto, ese yo es la única garantía de lo que se afirma. Conviene que el crítico dramatice su saber, asumiendo el yo en la escritura. Y el ensayo, que según vengo desarrollando, asume el acontecer del yo y sus figuraciones tanto como el estilo de la lengua literaria, es el espacio idóneo para una genuina crítica literaria, una crítica del gusto. 


\section{Conclusiones}

Al momento de estudiar la singularidad de la obra de Cyril Connolly tuve que precisar, en un primer paso, en qué consistía ésta, en rasgos generales: Cyril Connolly es un hombre de letras inglés, que escribe ensayos, con el agregado de que él es un personaje frecuente en ellos. Así, como en una serie de cajas chinas, dediqué la primera parte de este trabajo a esos tres aspectos, partiendo de un análisis general para luego establecerlo en el caso particular de Connolly.

El hombre de letras ha dejado de ser una función operante en el campo literario actual, y así su figura, de contornos difusos, no nos es tan familiar ni fácilmente definible. Las primeras búsquedas arrojan obvias vaguedades (alguien dedicado a las letras o las ciencias humanas) o confusas posiciones (escritor, erudito, alguien instruido), sin que por lo demás dejen de ser ciertas. Si bien la función específica es deudora de la Ilustración y el periodismo, cuando el campo literario comienza a afianzarse y ganar autonomía, prácticas similares son anteriores a este tiempo histórico. Las Noches áticas de Aulo Gelio muestran un interés por compartir notas y comentarios entre gente ociosa y letrada sobre las artes liberales, la lengua y las tradiciones; pero no se trata de estudios con fines didácticos, sino de curiosidades intelectuales que permitan obtener conocimientos mediante el placer de la lectura sin el rigor del estudio. Este grupo de hombres comparte una misma formación, que los separa de los iletrados, y acuerdan en los saberes tradicionales relevantes. El deseo de adquirirlos y disfrutarlos es lo que por esa época llaman humanitas, porque el interés y enseñanza de estas buenas artes intelectuales sólo corresponden al hombre. Si bien el humanismo, como movimiento emergente, es propio del Renacimiento, se da allí como una vuelta a aquellos principios y saberes; por tanto, podría hablarse de una continuidad ininterrumpida de esta tradición occidental. El mismo Connolly, ante la crítica soviética, declara: "We acquired our values from Greece, Rome and the Bible, from de Rennaissance; we are in fact humanists" (1953: 197). El otro gran precursor del hombre de letras, siguiendo esta línea del tiempo, fue Michel de Montaigne. Posteriormente, dada la creciente autonomía del campo literario en la Francia del s. XIX, esta función alcanza su apoteosis en la figura prototípica de Charles Sainte-Beuve, que fue un modelo para la mayoría de los men of letters ingleses.

En la Inglaterra de los siglos XVII y XVIII toma forma una esfera pública burguesa de relativa coherencia, como espacio donde se pone en circulación un 
intercambio libre e igualitario de discursos racionales, basados en los valores humanistas. En ese momento, la crítica, de efectiva comunicación con su público, cumple una función didáctica en la vida cultural, estableciendo las maneras y los gustos de un cuerpo social que intenta aglutinarse en valores y discursos comunes. La Revolución Industrial, con la respectiva intrusión de los intereses comerciales privados, pone en jaque el consenso discursivo de los desinteresados caballeros; los ligeros ensayos que arbitraban sobre las costumbres y el buen gusto se ven reemplazados en las revistas por otros más virulentos y específicamente políticos. Algunos críticos, no resignados a someter las reflexiones estéticas a los dictados políticos, se vuelven al escrutinio de su arte con un discurso idealista, que separa ahora cada vez más esta esfera de la social; así es como empieza a pensarse en Inglaterra en un campo literario relativamente autónomo. El hombre de letras se vuelve hacia dentro del campo, diferenciándose del propagandista en la conciencia de la palabra como arte, explorando las potencias del estilo; sin embargo, no se trata tampoco de un especialista. En tanto portador de un saber ideológico general y no el exponente de una disciplina especializada, trata aún de cohesionar la esfera pública mediante un discurso basado en el sentido común. Se convierte así en centro de un dilema ideológico y técnico que no ha dejado de afectar a la crítica: ante el avance del poderío mercantil y la desintegración de la antigua esfera pública, se refugia en las universidades y pierde su relevancia social, a la vez que afina sus teorías e instrumentos cognitivos, estableciéndose cada vez más como discurso obligado a autolegitimarse; o se mantiene en el ámbito público perdiendo su integridad en la imbricación con los intereses políticos y mercantiles. Por esto, el hombre de letras se encuentra en el dilema de si emitir sus juicios en nombre del público general o de las minorías letradas; de si adopta el discurso del periodista o el del erudito: distanciado de uno por sus facilidades y del otro por su enclaustramiento, sus funciones se vuelven cada vez más problemáticas. Entre la universidad y el mercado, el hombre de letras tradicional es ignorado por la cátedra -dada su falta de especialización- tanto como por la masa de lectores.

Así, el hombre de letras, entre la generalidad y la especialización, el amateurismo y la profesionalización, enarbola un discurso ajeno a la academia y a la vulgarización, atento al estilo, y basado en la experiencia del objeto artístico, sin especificar ningún sustento teórico. Para la época de la Segunda Guerra Mundial, cuando Connolly termina de publicar sus obras mayores, es ya una figura nostálgica, en concomitancia con el humanismo cuyas creencias y valores son puestos en problemática 
supervivencia con los sucesivos desastres de Occidente. Tanto Connolly como Edmund Wilson y V. S. Pritchett son llamados los últimos hombres de letras del mundo anglosajón; sus ensayos, ajenos a las modas teóricas y los dictados del mercado, resultan cada vez más privados de circulación, público y legitimidad. Se ven obligados a limitarse a unas escasas columnas periodísticas, cuando el antiguo hombre de letras podía antes explayarse en decenas de páginas en las revistas. Cyril Connolly se vio a sí mismo, y de ello dejó constancia en sus obras, como el último eslabón de una cultura humanista en franca decadencia; encarnó al hombre de letras totalmente dedicado al arte, a las bellas letras, el estilo y las maneras, en un campo cultural europeo escindido por el mercantilismo, los progresos científicos y las guerras.

El hombre de letras, en su escritura, se sirve del ensayo; este género no le es privativo, pero es esencial a sus especulaciones. Como antes dije del hombre de letras, no podría hablarse de 'ensayo' antes de la primera publicación del libro de Montaigne; sin embargo, él mismo se reconocía en deuda con Séneca, Plutarco y el mencionado Aulo Gelio. Pero, a diferencia del tratado de la antigüedad, Montaigne dice no recurrir a la dispositio, sino escribir lo que pasa en ese momento por su mente, sin recurrir a teoría, sistema o estructura previos a la escritura. Y además, en vez de intentar llegar a una verdad generalizable sobre el tópico de su interés, concentra su acercamiento en lo singular del objeto y en la singularidad de su relación con éste. Por tanto, arriba a un estilo propio basado en la falta de estructura, y a un saber fruto de la experiencia que dice una verdad esencial sobre su objeto que, sin embargo, no es generalizable fuera de ese texto. Se trata de un saber que depende de la experiencia y no de la razón, porque su fin no es contribuir al conocimiento de la materia en cuestión, sino dar a conocer la experiencia singular del ensayista en relación con la cosa mientras escribe. Por esto mismo, dado que no se escribe desde la abstracta razón, entran en juego en este contacto el ensayista en tanto individuo, su cuerpo y sus circunstancias. En cuestión, estamos ante un escrito en prosa donde se presentan en primera persona las reflexiones ocasionales de una subjetividad sobre un objeto cualquiera. En tanto el objeto sea literario, el ensayo interpela a la literatura según su modo, el del arte y el estilo, y no a manera de metalenguaje; sin embargo, no siendo la literatura su tema, el ensayo es literario en el sentido en que en él se da un modo de conocer literario, un saber que depende de la legalidad de lo literario.

Bajo la práctica señera de Francis Bacon, el ensayo fue enseguida introducido y practicado en la tradición literaria inglesa, con figuras de la talla de Carlyle, el Dr. 
Johnson, Hazlitt, Oscar Wilde, Pater, T. S. Eliot o Virginia Woolf; es en esta tradición en la que si inscribe la obra de Cyril Connolly. Como su admirado Sainte-Beuve, entre sus ensayos practicó el retrato literario, ocupándose de contemporáneos de la talla de Joyce, T. S. Eliot y Hemingway. Connolly se volcó exclusivamente a la práctica de la crítica literaria en tanto autor de ficción fracasado, pero, en vez de ocultarlo, hace de este punto de vista el eje de sus escritos. Así, al ocuparse de estos autores, mezclando las anécdotas con las reflexiones, busca en ellos los aciertos y errores en la práctica del arte, porque escribe desde su potencialidad de autor más que de crítico; interroga sus vidas para entrever las posibilidades en sí de lo literario. Al crear en su escritura una figura de autor, Connolly elige la del crítico en tanto escritor fracasado; la del hombre de letras que, dados sus talentos, prometía una gran obra, pero algo le impidió lograrlo. Sus ensayos son la búsqueda y la lectura de esa falla; lee en los autores que admira las truncas potencialidades de su obra inexistente. Es por eso que nunca está ausente en su texto, siempre nos remite a sí mismo, porque al fin, como Montaigne, nos habla más de sí, de su experiencia literaria, que de la carrera objetiva de los demás; nada más ajeno a su práctica que reducir el yo en la crítica literaria. No se borra de sus lecturas porque lo que pretende es buscarse y configurarse en ellas; afirma ciertos valores de la literatura siempre a partir de la suya propia, manifiesta o fantaseada.

Dadas las búsquedas que Connolly, en tanto hombre de letras, manifiesta en sus ensayos, son profusos en sus escritos los procesos de autofiguración; esa acentuación de lo particular es un rasgo típico. Los géneros del yo comienzan a tomar forma con el humanismo renacentista, cuyas características tangencialmente vengo desarrollando, con sus especulaciones en torno al hombre, que abren la posibilidad a un espíritu de individualismo. El relativo corte con el teocentrismo de la Edad Media provoca una inestabilidad gnoseológica; en consecuencia, mediante estas escrituras intimistas el hombre busca y construye su lugar a la vez que intenta un nuevo orden de lo conocido. Esta escritura de sí es un acto performativo, porque ese ser no es anterior a la escritura sino que se configura mediante ella; y ese ser, en tanto escrito, es ser para otros, al igual que el escritor es otro de sí mismo en tanto se escribe. Esa imagen tanto privada como pública que el escritor crea, para cumplir su función, depende de procedimientos literarios; son estrategias de autor para configurar una imagen de sí en el campo literario a la vez que expresan sus creencias y valores sobre el estatuto del escritor y la literatura. El ensayo no es el género privilegiado de las escrituras del yo, como pueden serlo la autobiografía, las memorias o la novela autobiográfica; pero considero que el ensayo, en 
tanto todo lo que se dice depende de la creación del punto de vista de ese yo, fundamento de la experiencia, es una manera peculiar de la emergencia de esa instancia. El yo en relación con la cosa es la verdadera experiencia que el ensayo pone en juego. Y dado que el ensayo carece de sistema y estructura, muchas veces el punto de vista, el ensayista, es el que da unidad a los fragmentos de escritura; no hay detrás disciplina o método que sustente su acercamiento. No se silencia al sujeto, sino que, asumiéndolo, se da en el saber su aparición fundante. El ensayista, buscándose y creándose al escribir el proceso de su relación con su objeto, se vuelve personaje de su propio discurso, se figura como autor de su propia escritura. Escamotear su presencia en el texto, sería para el ensayista borrar la única prueba de todo lo que se dice, dado que se trata de su experiencia. $\mathrm{Y}$ es por esto que la autofiguración es tan importante para el ensayo, porque no basta saber que lo que se predica es fiel a una experiencia, sino que, sabiendo quién y bajo qué circunstancias tuvo esa experiencia, el lector adquiere elementos más complejos y certeros para la apreciación del saber relativo que esa escritura manifiesta.

Desde sus primeros ensayos Connolly se configura como el ensayista en tanto escritor fracasado. Parece una paradoja, porque no se trata de un escritor fracasado, sino de alguien que desde sus comienzos decide presentarse así. Connolly no fracasó en el campo literario, sino que fracasó para sí, midiéndose con sus expectativas. Su obra tuvo éxito, pero no era la obra que él deseaba; su temperamento lo incapacitaba para las obras que su educación le enseñó a valorar más. Sus escritos fragmentarios, sus proyectos fragmentarios, lo convirtieron en un hombre de letras exitoso, que demostró tener el hábito de la literatura; pero carecía del hábito del arte del que depende la realización de una gran obra. Así, sus escritos actúan su culpable inactividad, son escritos sobre su no-escritura; pero rastrea en ellos, establece y analiza cuál es la vida que el artista debe llevar para realizar una obra, cuáles los hábitos y las técnicas. Dedicó lo mejor de su capacidad crítica y literaria a dilucidar estas cuestiones, que él no podía llevar a cabo por su temperamento hedonista y perezoso; por esto la figura que construye de sí como autor es la del fracasado ejemplar, el que todo lo tenía y no pudo, la promesa. Por tanto para Connolly la crítica es siempre una capitulación, y siempre valora las facultades creativas sobre las de la inteligencia; la crítica es para él la manera de buscar y establecer ese valor absoluto literario que en tanto escritor tendría que alcanzar. Pero la crítica a su vez se convierte en causa frustrante de esa otra escritura, que se aleja en el proceso. El crítico, mediante su actividad, se impide la literatura, que es lo único que desea; establecer el valor no es crearlo, pero es el deseo de crear ese 
valor el que le permite establecerlo. En ese proceso es que Connolly, en búsqueda de la falla en su vida que no lo permite la gran obra, escribe sobre el fracaso en él de la obra, y ésta es su obra. El ensayo se vuelve el escenario de la autofiguración de un artista fracasado que, mediante esta escritura, deviene hombre de letras exitoso.

Los que llamé libros mayores de Cyril Connolly se publican uno en la inminencia de la Segunda Guerra y el otro cercano su fin: Enemigos de la promesa en 1938 y La tumba inquieta en 1944. El primero es un ensayo de crítica literaria que se divide en tres partes. En la primera se interroga sobre el estilo, y a los fines del análisis establece una dicotomía entre 'mandarines' y 'modernos'; su propósito es hacer una síntesis para encontrar el estilo adecuado para su época, y así poder escribir un libro que dure por lo menos diez años. En la segunda parte, una vez hallado el estilo conveniente, establece los que llama "enemigos de la promesa"; es decir, el artista no sólo debe poseer el talento y el estilo adecuado para poder escribir una obra maestra, sino que debe llevar una vida acorde a la producción de dicho arte, evitando los escollos que la vida civil le presenta: periodismo, política, familia, drogas, éxito, etc. Puede verse que Connolly sigue ejerciendo la crítica en tanto modo de establecer las posibilidades de una obra aún no escrita. Pero lo más novedoso de este libro se encuentra en su tercera parte, que desarrolla la autobiografía de formación del crítico. Esto, que pudiera parecer un ejercicio de exhibicionismo, es, por el contrario, un desvelamiento, su confesión de parte. Por un lado, en su escritura intenta poner en práctica los hallazgos de la primera parte; por otro, dramatiza ante el lector la formación del crítico, lo que su familia y educación hicieron de él: la impopularidad del trabajo, la valoración del carácter por sobre la inteligencia, el humanismo clásico etoniano, el romanticismo decadente que permea sus sentimientos tanto como la enseñanza de los clásicos, la endogamia escolar, con sus tempranos laureles, que anclan a algunos alumnos en una adolescencia perpetua. Las problemáticas y tensiones, tanto emocionales como estéticas, que se desarrollan en esta época son las que determinan, de alguna manera, el punto de vista del análisis hecho en las primeras dos partes. No sólo busca Connolly en ese pasado las causas de la pereza que lo ha incapacitado como artista, las fallas de su carácter, sino que nos presenta las lecturas e ideas que intervinieron en la formación de su juicio para que el lector pueda medir así la validez de su crítica, dado que hace patente que las teorías que desarrolla en la primera parte tienen origen en su experiencia misma. Lo original de esta obra no es entonces su retórica autobiográfica sino su uso autobiográfico: expone al 
crítico como objeto de conocimiento, dado que, en tanto subjetividad que enuncia en el ensayo, es el fundamento único de sus juicios.

La tumba inquieta, libro fragmentario escrito durante la Segunda Guerra, es un libro de crisis. Por un lado, la crisis del humanismo europeo, en que el autor se formó, vivió y cuyos valores le son tan caros, y en ese sentido es que su prosa adquiere un carácter elegíaco. Por otro, una crisis personal: Connolly se separa de su mujer, cumple entre tanto cuarenta años, y todavía no pudo escribir la obra que lo desvela. En este último sentido, este libro continúa la búsqueda del anterior: qué es una obra maestra y cuáles son las trabas que le impiden escribirla. Pero en este caso no estamos ante un ensayo de partes estructuradas, sino ante la emergencia de la escritura en sí: citas, reflexiones, extractos de diarios, fragmentos. La escritura, en su suceso, se convierte en instrumento del conocimiento de sí a través de la autofiguración. A diferencia del libro anterior, el personaje no se desarrolla en el devenir de la autobiografía, sino que se va creando una imagen cambiante a través de cada fragmento, en el momento de la escritura; pero se presenta también en tanto proyecto de sí mismo. Casi la mitad del texto está compuesto de citas, la mayoría de ellas en francés; mediante ellas se lee a sí mismo en tanto posible potencialidad de autor a través de los autores que admira. No son citas de autoridad sino de posibilidad, de identificación; si se busca a través de la introspección también se objetiva al mirarse en otros que han escrito las obras que él desea. Pero la cita también le sirve en cuanto lo vincula a una tradición, ese humanismo europeo que ve desaparecer y que él en tanto hombre de letras siente como deber reafirmar. En tanto libro de fragmentos, también La tumba se vincula con la tradición: Montaigne, Pascal, la Rochefoucauld, Chamfort; autores que a su vez Connolly cita y toma como modelos en su propio libro. El fragmento participa del carácter del ensayo en su inacabamiento, pero no se trata de un pedazo, como tampoco algo cerrado sobre sí mismo, se trata de algo que se proyecta, que deviene. El fragmento se presenta como una crítica de la obra, un cuestionamiento sobre su posibilidad; su misma falta de sistematicidad le es esencial porque cuestiona el principio mismo que pone orden a las razones. Esta fragmentación se vuelve signo de la ausencia de la Obra que es el deseo último de Connolly; su escritura toda, que manifiesta su incapacidad para la Obra, traza los contornos de esa Obra y se vuelve obra en ese mismo movimiento. Búsqueda a la vez que realización, su escritura se vuelve obra de la ausencia de la Obra, tiende hacia ella a la vez que se realiza. Al manifestarse sobre la obra esta escritura no puede dejar de ser una crítica, pero dice menos de aquella que de las características del crítico que la 
desea e imagina, y es por eso que éste se vuelve, en el fondo, el tema de su indagación, sujeto del arte. Y Connolly, en la escritura de esta búsqueda de sí como artista, se vuelve artista en el proceso.

Si por algo me parecen esenciales las instancias que vengo tratando es por el papel fundamental que desempeña el crítico en la formación del valor literario. Dentro de la llamada República Mundial de las Letras, dentro de un campo literario autónomo, que se rige por sus propias leyes, a lo largo del tiempo la literatura va acumulando procedimientos puramente literarios. Las apreciaciones y juicios sobre las obras dicen que estas, dentro del campo, poseen algún tipo de valor; están así por un lado las obras, en tanto objeto del valor, y por otro un grupo de actores capaces de otorgar ese valor y manipularlo; el valor literario por tanto descansa en los juicios que emiten quienes son considerados idóneos, los que poseen 'nombre' o 'crédito', dependiendo de la creencia que en ellos se profese. Los críticos son así quienes legislan literariamente, dado que su juicio es legítimo en tanto se reconoce su competencia específica; acumula capital simbólico en tanto se cree en él como depositario de una cultura literaria. Cierta unidad de juicios en este ámbito internacionalizado hace que algunas obras se vuelvan clásicas y así se establecen como patrones, unidades de medida, fundamentales para la valoración de otras obras y la conformación del canon literario. El gusto esgrimido para emitir estos juicios es fruto de una frecuentación de las obras, y si nadie posee el gusto absoluto, a unas personas se les reconoce más que a otras. La amplia experiencia en un arte determinado, teniendo por medida lo que el consenso del tiempo ha considerado mejor, permite comparar y emitir juicios. Esta experiencia internaliza en el crítico los principios formales de la ejecución artística, sea luego consciente o no de la verdad teórica de su competencia.

Los intentos por hacer de la crítica literaria una ciencia no pueden sin embargo dejar de reconocer el carácter subjetivo y dependiente de la experiencia que todo juicio sobre una lectura conlleva. El mismo Barthes, que no sólo participó, sino que fue un teórico importante de muchos de estos movimientos, sobre el final de su carrera se volvió cada vez más hacia el reconocimiento de la intrusión del individuo en el proceso del saber, un saber autobiográfico, que está trazado en el cuerpo. Barthes entonces, como Connolly, cree que no se piensa más que con la experiencia, por tanto cree fundamental al sujeto como base de conocimiento. Para abordar la literatura hay que 
asumir el estilo en el abordaje, para dar una respuesta literaria a lo que me interpela desde el texto, y así, no debe el sujeto situarse a distancia del objeto sino adherirse a él.

La creencia y la confianza en la respuesta individual del crítico, basada en su educación y su gusto, como manera de establecer un estándar del juicio, fueron cada vez más cuestionadas durante el s. XX, tratando de reemplazarlas por metodologías objetivas como fundamentos del juicio. Sin embargo, la ciencia positiva no puede reemplazar la experiencia de lecturas acumuladas que le permiten al crítico comparar y así emitir juicios sobre el arte. La crítica es irreductible ante el discurso 'cientificista', dada la imposibilidad de poder decir algo del texto desde el punto de vista de la ciencia positiva. El gusto, como el placer, del que dependen los juicios sobre arte, se consigue desde una lógica-otra imposible de rastrear mediante el saber positivo, porque aparece en el momento en que se permite al sujeto hablar desde la intimidad de su experiencia. No puede haber una ciencia de lo bello, sino una crítica; no puede haber una ciencia porque lo bello en la cosa es una cualidad formal, un significante sin significado, algo que la ciencia no puede reducir en tanto excedente. El gusto así se encuentra entre un saber y un placer, pero es un saber que no puede dar razones de sí, porque se sustenta sobre un puro significante, y se basa en un placer de lo que en la cosa es pura forma. Eso que en el objeto es forma, excedente del conocimiento, se aprehende mediante una intuición, que por tanto no sólo pertenece al objeto sino que depende del sujeto. Por eso en la crítica es fundamental poner de relieve quién sabe y quién siente ese placer, dado que aplica su gusto (saber de lo bello) como única facultad para el conocimiento de la belleza en tanto excedente de otras facultades teóricas.

Mediante el recurso a la teoría o la impersonalidad gramatical, el crítico estará escamoteando así el único fundamento de sus predicados, que es él mismo en tanto cuerpo de ese saber y esa escritura. Debe impugnarse por tanto en los metalenguajes la falacia de la objetividad, dado que el recurso a la abstracción es un enmascaramiento de una subjetividad imposible de erradicar y que, entonces, sería mejor asumir con total conciencia y exponerla también como objeto de conocimiento. En Connolly el saber es siempre fruto de una experiencia que no se sustrae al lector, por eso el constante recurso a la autofiguración en sus críticas. La apreciación de las obras predicará tanto más de ellas en cuanto se nos ofrezcan más elementos sobre el sujeto de ese saber. Frente a la generalidad de la ciencia, una crítica que pretenda decir alguna verdad de la literatura debe asumir el 'yo' en su escritura, dado que para bien o para mal, no puede ser sustituido como sujeto de conocimiento. Porque al arte interpela al crítico en una 
relación concreta, que no puede más que ser vivida y relatada desde el 'yo'. La crítica debe asumir y afirmar ese 'yo' como evidencia de una verdad peculiar de la literatura, porque desvelar ese punto de vista personal es la única garantía de lo que se afirma es exacto, dado que depende de la experiencia particular.

El ensayo es el elemento idóneo para una crítica del gusto en tanto juicio de lo bello; como este saber no puede dar razones de sí, lo que debe hacerse es dramatizarlo, espectacularizarlo mediante la autofiguración del ensayista, cuya experiencia de la literatura es el único fundamento de lo que afirma. Prestándose como objeto de conocimiento y asumiendo el yo del que depende su escritura brindará a su lector una verdad más acorde al acontecer real de la experiencia artística; sin reducir la literatura, objeto de su deseo, a otros discursos puede afirmar en el ensayo una verdad literaria.

Entre los temas entrevistos en este trabajo que se podrían profundizar, tres llaman mi atención. Uno sería ver cómo afectan los modos de circulación de los textos a los géneros y los actores del campo literario; en este caso en concreto: cómo afectó la progresiva desaparición de la revista literaria a la producción ensayística y qué papel tuvo en la marginación del hombre de letras. Otro sería ahondar en la comparación de la obra de Connolly con la de otros ensayistas contemporáneos, para poder en ese caso, al establecer las características diferenciales, entrever distintos caminos de la crítica que puedan ser revitalizados. Pero el que más me interesa es, y tal vez para el que esta investigación más pudiera servir como base, las posibilidades que el ensayo pudiera tener dentro de la universidad; es decir, en tanto escenario idóneo para ejercer una crítica del gusto, capaz de convertirse en la mejor manera de realizar un acercamiento verdaderamente estético a la literatura, que, por sobre todas las cosas, es un arte. Algunas reflexiones e hipótesis a seguir sobre el tema se encuentran en el ensayo de Alberto Giordano "Lo ensayístico en la crítica académica” (2005: 261-265). 


\section{Bibliografía}

ADAMS, Robert M. "Cyril Connolly and the Man of Letters" en The American Scholar. Págs 99-105. 2001.

ADORNO, Theodor, "El ensayo como forma", en Notas de literatura. Trad. Manuel Sacristán. Barcelona: Ariel, 1962.

AGAMBEN, Giorgio. Gusto. Trad. de Rodrigo Molina-Zavalía. Buenos Aires: Adriana Hidalgo, 2016.

AMÍCOLA, José. Autobiografia como autofiguración. Estrategias discursivas del yo y cuestiones de género. Buenos Aires: Beatriz Viterbo, 2007.

AULO GELIO. Noches áticas. Edición y trad. de Santiago López Moreda. Madrid: Akal, 2009.

BARTHES, Roland. El susurro del lenguaje. Más allá de la palabra y la escritura. Trad. de C. Fernández Medrano. Barcelona: Paidós, 1987.

Roland Barthes por Roland Barthes. Trad. de Julieta Sucre.

Caracas: Monte Ávila, 1978.

El placer del texto seguido por Lección inaugural. Trad. Nicolás Rosa (El placer del texto) y Oscar Terán (Lección inaugural). Buenos Aires: Siglo XXI, 2004.

La cámara lúcida. Trad. de Joaquim Sala-Sanahuja. Buenos

Aires: Paidós, 2012.

BERLIN, Isaiah. "Wilson en Oxford”. Vuelta n 135 (1988): 18.

BIOY CASARES, Adolfo. "Estudio preliminar" en A.A.V.V. Ensayistas ingleses. Selección y notas de Ricardo Baeza, estudio preliminar de Adolfo Bioy Casares. México: Clásicos Jackson, 1948.

BLOOM, Harold. Ensayistas y profetas. El canon del ensayo. Trad. Amelia Pérez de Villar. Madrid: Páginas de espuma, 2010.

2004.

BORGES, Jorge Luis. Obras completas IV. Barcelona: Emecé, 1996.

BOURDIEU, Pierre. El sentido social del gusto. Elementos para una sociología de la cultura. Trad. Alicia B. Gutiérrez. Buenos aires: Siglo Veintiuno, 2010.

BOYD, William. "Lessons in the art of living" en The Guardian. Saturday 26 October 2002. Consultado en: 
http://www.guardian.co.uk/books/2002/oct/26/featuresreviews.guardianreview14 $(7 / 12 / 17)$.

BOYKIN, Dennis Joseph. Wartime Text and Context: Cyril Connolly's Horizon. Sydney: The University of Sydney, 2007.

CASANOVA, Pascale. La República Mundial de las Letras. Barcelona: Anagrama, 2001 .

CATELLI, Nora. "Un mandarín, sin duda" en El País 31/12/2005. Consultado en: http://www.elpais.com/articulo/semana/mandarin/duda/elpeputec/20051231elpbabese 12/Tes. $(23 / 06 / 17)$

En la era de la intimidad, seguido de: El espacio autobiográfico. Rosario: Beatriz Viterbo, 2007.

CONNOLLY, Cyril. The Condemned Playground. Londres: Routledge, 1946. Ideas and Places. New York: Harper \& Brothers, 1953. Previous Convictions. New York: Harper \& Row, 1963. La tumba sin sosiego. Trad. Ricardo Baeza. Buenos Aires: Sur, 1949.

Traducción Aurelio Major. México: Fondo de Cultura Económica, 1993.

Obra selecta. Edición e introducción de Andreu Jaume. Traducción de Miguel Aguilar, Mauricio Bach y Jordi Fibla. Barcelona: Lumen, 2005. COLLINI, Stefan. "On not Getting on with it: The Criticism of Cyril Connolly" en Common Reading: Critics, Historians, Publics. Oxford: Oxford University Press, 2008. 9-19.

DOMÍNGUEZ MICHAEL, Christopher. "El maestro". Letras libres (abril de 2006): 79.

EAGLETON, Terry. La función de la crítica. Trad. Fernando Inglés Bonilla. Barcelona: Paidós, 1999.

ELIOT, Thomas Stearns. "Los clásicos y el hombre de letras" en Criticar al crítico. Trad. de Manuel Rivas Corral. Madrid: Alianza, 1967.

GARRIDO, Antonio. "Un clásico de la modernidad" en SUR.es. Viernes, 26 de mayo de 2006. Consultado en:

http://www.diariosur.es/pg060526/prensa/noticias/Cultura/200605/26/SUR-CUL265.html (8/12/17).

GIORDANO, Alberto. Modos del ensayo. De Borges a Piglia. Rosario: Beatriz Viterbo, 2005. 
Aires: Beatriz Viterbo, 2011.

GOOD, Graham. The Observing Self. Rediscovering the essay. London: Routledge, 1988.

GRAMUGLIO, María Teresa. "La construcción de la imagen". Tizón, Héctor et al. La escritura argentina. Santa Fe, UNL-Ediciones de la Cortada, 1992. 35-64.

GROSS, John. The Rise and Fall of the Man of Letters: English literary life since 1800. Chicago: Elephant, 1992.

GRÜNER, Eduardo. Un género culpable. La práctica del ensayo: entredichos, preferencias e intromisiones. Rosario: Homo Sapiens, 1996.

HARDISON, O. B. Jr. "Binding Proteus: An Essay on the Essay", en BUTRYM, Alexander J. (ed.) Essays on the essay. Redefining the genre. Georgia: University of Georgia Press, 1989.

HUME, David. De la tragedia y otros ensayos sobre el gusto. Trad. Macarena Marey. Buenos Aires: Biblos, 2003.

JAUME, Andreu. "Introducción" en CONNOLLY, Cyril. Obra selecta. Edición e introducción de Andreu Jaume. Traducción de Miguel Aguilar, Mauricio Bach y Jordi Fibla. Barcelona: Lumen, 2005.

KRAMER, Hilton, "Cyril Connolly's Horizon," New Criterion 8, no. 1 September 1989:

5-11. Consultado en: http://archive.fo/FJhes (7/12/17).

LACOUE-LABARTHE, Philippe y NANCY, Jean-Luc. El absoluto literario. Teoría de la literatura del romanticismo alemán. Trad. de Cecilia González y Laura Carugati. Buenos Aires: Eterna Cadencia, 2012.

LARA ZAVALA, Hernán. "V.S. Pritchett, hombre de letras" en PRITCHETT, V.S. El viaje literario. Cincuenta ensayos. Prólogo Hernán Lara Zavala. Trad. Ramón García. México: FCE, 2011.

LOPÉRGOLO, Julieta. "Los ensayos de José Bianco: entre la crítica y la literatura” en Boletín 9 del Centro de Estudios de Teoría y crítica literaria, diciembre de 2001, Facultad de Humanidades y Arte, Universidad Nacional de Rosario. Págs: 77-89.

LÓPEZ MOREDA, Santiago. "Introducción” en AULO GELIO. Noches áticas. Edición y trad. de Santiago López Moreda. Madrid: Akal, 2009.

LUKÁCS, Georg. "Sobre la esencia y forma del ensayo (Carta a Leo Popper)" en El alma y las formas. Barcelona: Grijalbo, 1970. 
MAJOR, Aurelio. "No hay fin de hacer muchos libros" en WILSON, Edmund. Obra selecta. Edición y prólogo Aurelio Major. Trad. Adriana Astutti y otros. Barcelona: Lumen, 2008.

MALPARTIDA, Juan. "Connolly, una vida leída” en Letras libres, marzo de 2006. 5658.

MARTY, Éric. Roland Barthes, el oficio de escribir. Trad. De Horacio Pons. Buenos Aires: Manantial, 2007.

MIGNOLO, Walter. "Discurso ensayístico y tipología textual" en Textos, modelos y metáforas. Veracruz: Universidad Veracruzana, 1984.

MOLLOY, Sylvia. Acto de presencia. La escritura autobiográfica en Hispanoamérica. Buenos Aires: Fondo de Cultura Económica, 1996.

MONTAIGNE, Michel de. Los ensayos. Prólogo de Antoine Compagnon. Edición y traducción de J. Bayod Brau. Barcelona: Acantilado, 2008.

MURAT, Jean-Christophe. "The Cost of Myth: Cyril Connolly and Romanticism" en The Space Between: Literature and Culture, 1914-1945 Volume 4: 1, 2008. 101-122.

NAVARRO REYES, Jesús. Pensar sin certezas. Montaigne y el arte de conversar. Madrid: Fondo de Cultura Económica, 2007.

OZICK, Cynthia. "Ella: retrato del ensayo como cuerpo tibio" en Metáfora y memoria.

Ensayos reunidos. Traducción de Ernesto Montequin. Buenos Aires: Mardulce, 2016.

PASTORMERLO, Sergio. "Campo literario" en José Amícola y José Luis de Diego Literatura. La teoría literaria hoy. Conceptos, enfoques, debates. La Plata: Al Margen, 2009.

PAYOT, Jules. El trabajo intelectual y la voluntad. Trad. de Domingo Vaca. Madrid:

Daniel Jorro, 1921.

PIGLIA, Ricardo. Formas breves. Buenos Aires: Anagrama, 2005.

."Bianco, aspectos de la nouvelle" en BALDERSTON, Daniel (Comp.) Las lecciones del maestro. Homenaje a José Bianco. Rosario: Beatriz Viterbo, 2006.

PERL, Jed. "Connolly's Unquiet" en The Review of Contemporary Fiction. N 31 (2011). Consultado en: http://periodicals.faqs.org/201104/2321643781.html. (25/09/11)

PRITCHETT, V.S. El viaje literario. Cincuenta ensayos. Prólogo Hernán Lara Zavala. Trad. Ramón García. México: FCE, 2011.

RANCIÈRE, Jacques. La palabra muda. Ensayo sobre las contradicciones de la literatura. Trad. Cecilia González. Buenos Aires: Eterna Cadencia, 2009. 
SAER, Juan José. Ensayos. Borradores inéditos 4. Buenos Aires: Seix Barral, 2015.

SALA-SANAHUJA, Joaquim. "Prólogo a la edición castellana" en BARTHES, Roland.

La cámara lúcida. Trad. de Joaquim Sala-Sanahuja. Buenos Aires: Paidós, 2012

SHELDEN, Michael. Friends of promise: Cyril Connolly and the World of Horizon. London: Hamilton, 1989.

THIBAUDET, Albert. Historia de la literatura francesa. Desde 1789 hasta nuestros días. Trad. Luis Echávarri. Buenos Aires: Losada, 1957.

TORRES FIERRO, Danubio. "Connolly, una íntima tristeza reaccionaria". Blanco y Negro Cultural. Núm. 612. 18/10/2003. Pág. 20. Consultado en: http://hemeroteca.abc.es/nav/Navigate.exe/hemeroteca/madrid/cultural/2003/10/18/020. html. $(25 / 09 / 11)$

WELLEK, René. Historia de la crítica moderna (1750-1950). Crítica inglesa (19001950). Versión española de Fernando Collar Suárez-Inclán. Madrid: Gredos, 1988.

WILDE, Oscar. Ensayos y Diálogos. Traducción de Julio Gómez de la Serna. Buenos Aires: Hyspamérica, 1985.

WILLIAMS, Raymond. Palabras clave. Un vocabulario de la cultura y la sociedad. Trad. de Horacio Pons. Buenos Aires: Nueva Visión, 2008.

WILSON, Edmund. "Un gemido desde la tumba inquieta" en Obra selecta. Edición y prólogo Aurelio Major. Trad. Adriana Astutti y otros. Barcelona: Lumen, 2008. 635639. 